Educatia 21 Journal doi: 10.24193/ed21 Open Access

\section{EDUCATIA 21 JOURNAL}

\section{Issue, No. 20/2021}

Indexed in:

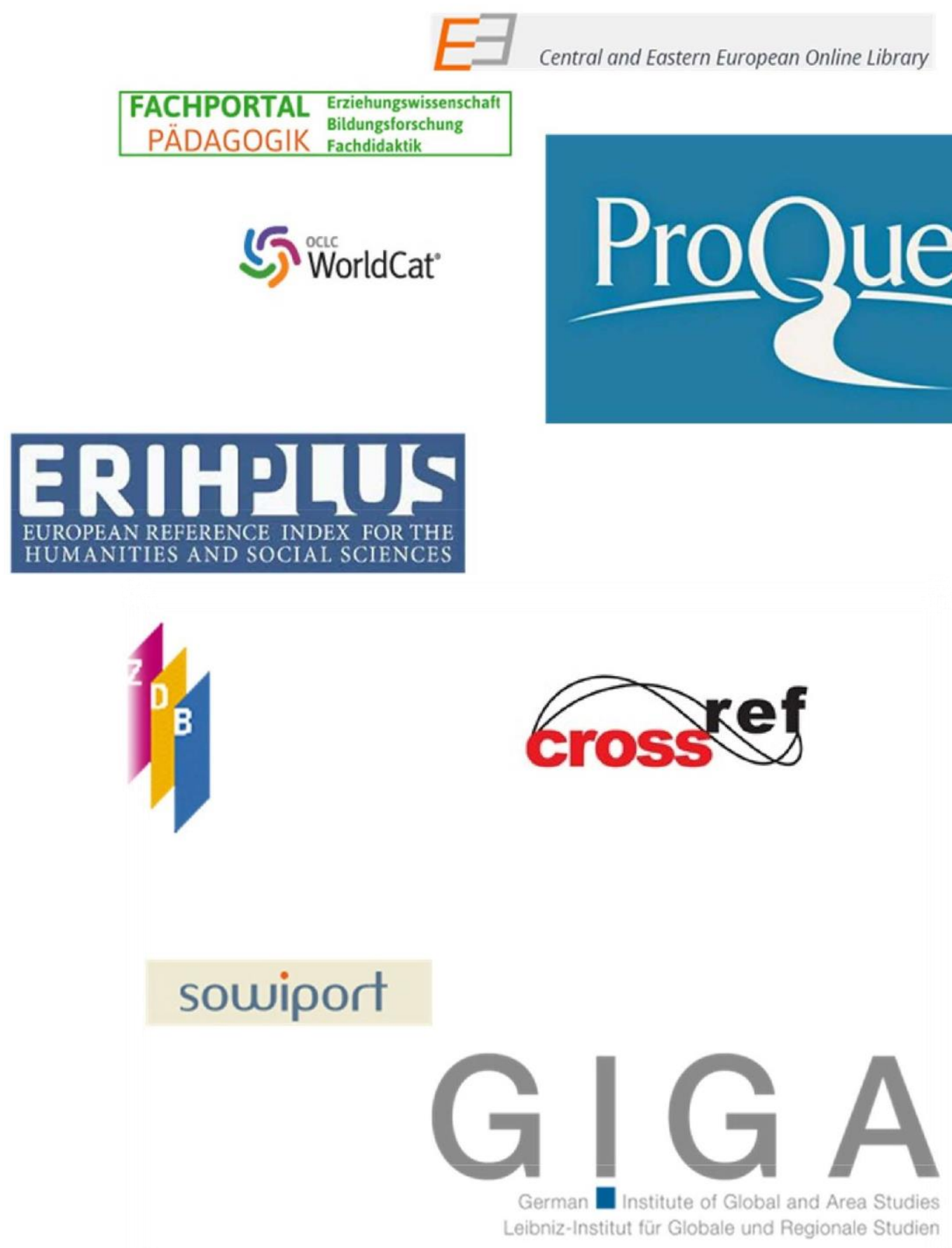


Editors in Chief:

MUȘATA BOCOȘ

ION ALBULESCU

Editorial Board:

HARRY DANIELS

JIM BRADLEY

THIERRY KARSENTI

FLORIN SĂLĂJAN
EKKEHARD NUISSL V. REIN

ION DUMITRU

GEORGE PATAKI

Executive Editor:

MARIUS BĂNUṬ

DANIEL ANDRONACHE

CIPRIAN BACIU

English Language Consultants:

RALUCA POP

RAFILA-ELISABETA ILOVAN 
Issue, No. 20/2021

Contents

Authors

Corina Colareza, Ioan

Neacșu

Vered Freedman,

Constantin Cucoş

Andreea Şițoiu, Georgeta

Pânișoară

Dorina Grigor, Benjamin

Frentsos

Diana-Crina Marin,

Mușata Bocoș

Silvia Alexandrina Jucan, Cristian Stan, Cornelia

Stan

Luciana Truța, Olga Chiș

Cristina Ispas

Torkos Henrietta, Torkos

Antonela

Veronica-Oana Irimia

Nicoleta-Eugenia

Meseşan, Diana-Crina

Marin

Rafila-Elisabeta Ilovan

Adina O. Câmpean, Horia Corcheș

Mihaela-Gabriela Cosma

Oneţ

Cristina S. Sălăgean,

Editha Coşarbă

Gina Florentina

Tudorache
Article Title

Page

Addictive Behavioural Manifestations of Adolescents in Romania

4

Teaching Facilitators' Perceptions of the Contribution of Three Internship Workshops Models

The Relationship Between the Emotional Intelligence of a 21st Century Adult and His or Her Parental Competence

Experiential Learning and Curriculum for Romanian Primary School Education in the Fundamental Acquisition Stage

Strategies to Improve Children's Interest in Reading Activities

Use of Multisensory Room in the Development of Psychomotricity in students with Autism Spectrum Disorder and Intellectual Disability

Criteria for Adapting Students' Practices to Current Conditions

Online Education - a Reality of Our Times

The Role Of Literature As Vocabulary Teaching Instrument Of A Foreign Language In Middle School

Scouting Activities in Maintaining the Wellbeing and the Health of High School Students

Aspects that could be Enhanced during the Initial and Continuous Training of the Primary School Teachers from Romania

Experimental Program For School Integration Of Re-Migrant Middle School Students With Learning Difficulties In Romanian Language And Literature

Between Fear and Confidence. The influence of Feedback on a 103 Student's Self-Perceived Image

Towards a Transdiciplinary Systemic Approach to National Heritage-Based Learning. Curricular Insights into the Romanian Art Education Reform in the Glocal Transformative Age

Parent Personality Traits During Covid-19 Pandemic: a 120 Correlational Study

\section{Book Review}

Educația digitală

133 


\section{Addictive Behavioural Manifestations of Adolescents in Romania}

Corina Colareza, Ioan Neacșu 


\title{
Addictive Behavioural Manifestations of Adolescents in Romania
}

\author{
Corina Colareza ${ }^{a^{*}}$, Ioan Neacșu ${ }^{b}$ \\ a "Edu Bizim" Educational and Cultural Center, 20, Oițelor Street, Sector 4, 040278, Bucharest, Romania \\ ${ }^{b}$ University of Bucharest, The Faculty of Psychology and Education Science, 90, Panduri Street, Sector 5, 50663, Bucharest, Romania
}

*Corresponding author: corinacolareza@yahoo.com

\section{Abstract}

\section{Keywords:}

adolescents; educational values; unheathy lifestyle; risky behaviour; addiction.
The study examines, through a concrete research, the analysis of perceptual, ideational, attitudinal, social, family and personological factors, with cumulative-progressive effects in the genesis of the main primarily addictive behavioural forms, in groups of adolescent pupils.

The approach of the topic is an interdisciplinary one, the dominant being the psychological, sociological and pedagogical dimensions, in a context seen as a reality lived and expressed verbally by the teenagers constituted investigatively in a randomly structured sample from different urban localities, either as opinions or as behavioural social and emotional-affective states specific to adolescence.

The qualitative arguments and the statistical results are the materialization of the application of a valid research methodology, relevant in its associative and explanatory interactional complementarity.

The conclusions of the study are relevant due to their functionality, which can possibly materialize in minimal positive interventions prior to the actual addiction in adolescent pupils in today's Romania.

\section{Zusammenfasung}

\section{Schlüsselworte:}

jugend; bildungswerte; ungesunder; riskoverhalten; sucht.
Die Studie untersucht, durch eine konkrete Forschung, die Analytik von Wahrnehmungs-, Ideen-, Einstellungs-, sozialen, familiären und persönlichen Faktoren mit kumulativ-progressiven Auswirkungen auf die Entstehung der wichtigsten primären Sucht induzierenden Verhaltensformen in Gruppen jugendlicher Schüler.

Der Ansatz des Themas ist interdisziplinär, wobei die psychologische, soziologische und pädagogische Dimension in einem Kontext dominiert wird, der als eine Realität angesehen wird, die von den Jugendlichen gelebt und mündlich ausgedrückt wird, die in einer zufällig strukturierten Stichprobe aus verschiedenen städtischen Gegenden untersucht wurden. Die Hauptverhaltensformen werden entweder ideologisch oder als Meinungen oder als soziale und emotional affektive Verhaltenszustände, die für die Adoleszenz spezifisch sind, identifiziert.

Die qualitativen Argumente und die statistischen Ergebnisse sind die Materialisierung der Anwendung einer gültigen Forschungsmethodik, die für ihre assoziative und erklärende interaktive Komplementarität relevant ist.

\section{Introduction: contextual landmarks and openness to the problem}

The topic of today's adolescence/adolescents is one of major interest for the public consciousness of a modern society, as well as of several categories of socio-human actors, educators and parents alike.

From the perspective of the age/period criterion of personality development, adolescence was marked by an unsuspected complexity of the transformations. So, adolescent subjects have to go through and face them on multiple levels psycho-emotional, biological, social, lifestyles, role models, action and educational projects, and last but not least the vibrational-energetic rhythms and communication of values at the level of generation and intergenerational level (Neacşu, 2010).
The concept integrates and highlights controversies, calling for innovative paradigmatic approaches is recognized to be, at least from the perspective of this paper, a syntagmatic one expressed in what we call and debate today: lifestyle - a complex, multidimensional and strongly personalized at geopolitical, cultural and intercultural level.

In the existentially context of socio-adaptive process, young people find unsuspected challenges, which generating behaviours and behaviouralattitudinal reactions of value, materialized in the most diverse psychological profiles. Many of these are learned others imitated/promoted/allowed by family or discovered in reference groups, some quickly taken 
over or integrated into the holistic Self. We frequently identify contexts and situations that generate identity crises, with effects on the erosion of self-esteem, transformation into deviant behaviours, internalization of negative values, accompanied by introverted reactions, hidden, difficult to identify and, where appropriate, to correct.

Adolescence, like preadolescent childhood, is a period considered to be sometimes optimal, sometimes critical in human development, due to either neurocerebral plasticity or frequent exposure to impact with harmful factors, with the status of determination, conditioning or influence that develop effects of duration, more or less marked socially and educationally.

Social interventions with correct feedback and health, at different stages of adolescent development have or can have positive effects. The appearance of puberty brings with it physical and mental transformations during which any intermediate evaluation of an uncertain result leads, in general, to the decrease of the optimal potential, of the reduced integration, of the diffuse valorisation of the socialeducational optimism. All this, during adolescence, sometimes fluctuates significantly, until, as progress in the maturation process, the characteristics of the stability of youth and the transition to normal adult life appear.

National statistics compiled by specialized institutions in Romania and internationally provided interesting data on the state of affairs (Iliescu R. et al, 2016). The number of adolescents with significant deficits in health is increasing (see data from the Institute for Research on Quality of Life, the Institute of Educational Sciences - recently amended, the National Institute of Statistics, etc.). As a gender structure, we have about $25 \%$ boys and about $30 \%$ girls with such manifestations, most of them being in the education system (87\%).

Naturally, a small number of adolescents are not investigated who report that they work, as well as some who are not included in the education system or in the labour market.

Categorically, risk behaviours are approached explicitly, transparently, they did not avoided.

Thus, for alcohol consumption, a high percentage, more than $40 \%$ of the adolescents confess that they consumed alcoholic beverages at least once, with decreasing ages, around $20 \%$ for those under 14 years of age, with greater variations and differentiations between boys and girls, both in urban and rural areas. Less studied, additionally were the type and amount of alcohol consumed.

For tobacco consumption: $23 \%$ of teenagers confess that they have smoked at least once, until the age of 14. After this age, the number is increasing: $33 \%$ compared to boys, versus $16 \%$ girls, and in urban areas, the percentage is slightly higher.

Drug consumption: almost $3.8 \%$ of adolescents have experienced one type or another of drugs, this percentage increases to 5.4 after 14 years.

Sexual behaviour has a percentage of $15 \%$ of adolescents, who say they have sex, of which $23 \%$ boys and $11 \%$ girls, in urban areas and in rural areas slightly lower. The age of 15.5 is the average age at which some teenagers began their sexual life. We currently record a relatively large number of teenage girls who have given birth to a baby!

Gambling and video games in excess, accompanied or associated with other vulnerabilities, say researchers at Oxford University, significantly reduce health concerns, reduced daily healthy living schedule, relevant lifestyle changes of adolescents with some risky manifestations.

Psychophysical exhaustion is or becomes an easily predictable or predictable consequence of the presence of the above-mentioned factors. A report published in 2016 by the American Journal of Critical Care, analysed the prevalence of causal factors, including the reduction of cognitive reserves, especially in the conditions of registering a pathology generated by drug use.

Specifically, we talk about reducing generation of new neurons in the hippocampus, the states appearance of violence, reduces mentality of blocking effects "fixed mindset versus growth mindset" by Siegel (2013).

In some surveys, Patrick \& Maggs (2015) conducted on a number of 4,842 students aged between 9 and 11 years, which confirms an increased percentage $(22 \%)$ of those who had consumed alcohol at the offer of disadvantaged social parents. Like this, they were being confident that this could increase children's responsibility or inoculate them with the idea that it is dangerous to drink a lot of alcohol, and children would think that their parents, loving them, could not want or hurt them. 
The results show sensitive and worrying changes in the expression and appeal of adolescents' behaviour depending on the problems they had to solve: the younger ones confidently turned to teachers and parents, and the older teenagers, friends or discreet sources: Internet, close friends.

The causal factor of behaviours with disorders founds in a rich series of metatheoretical analyses. Among synthetically expressed can be identifiable: globalization, dissonances in the culture of values, major ruptures between social tissues, clash of identities, passivity of educators' criticism, minimizing effects negative, lack of positive balance, some in the form of chronic, mental, social or emotional disorders.

\section{Theoretical foundation}

Adolescence is a topic much debated by pedagogues, psychologists, sociologists, culturologists, doctors, etc., being a generator of opinions and many differences. It considered both the "ungrateful age" by some and the "golden age", in the opinion of others. According many authors and specialized studies, adolescence is also an "age of crises, anxiety, insecurity" is often better promoted., dissatisfaction, disorders», but also «the age of great impulses», of creative potentials, a window open to great personal projects, an area of self-awareness development, visibly outlined by the presence of the following basic components (see Figure 1):

Figure no. 1 The basic components of self-awareness in adolescents

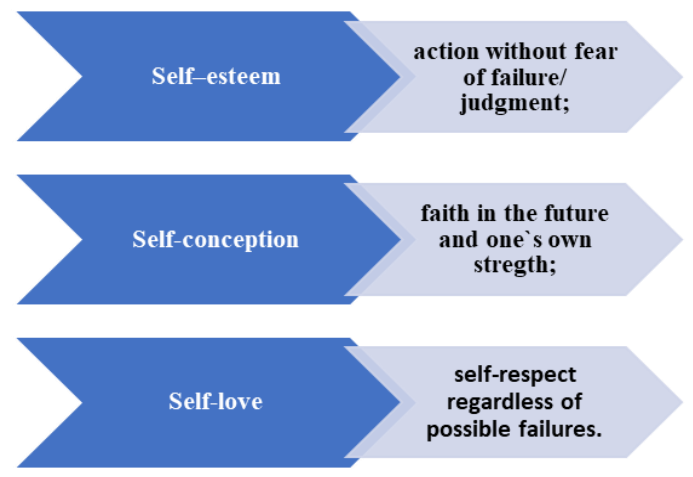

The development and internalization of selfawareness (Neacșu, 2010) is internalized in the form of a conduct formed to control general behaviour, including the assimilation of attitudes, roles, values, other than family.

An interesting approach in the context of our paper is that, which presents adolescence and age-specific behaviours around self-concept and self-esteem, analytically expressing a complexity of differentiated, personalized typologies (Neacșu, 2010).

The languages of adolescent groups often differ from the standard/standard language of the society in which they live. Attitudes, gestures and expressive ways of speaking not found in other age groups are borrowed/formed.

At this age, due to the features mentioned and many defined in specialized studies with linguistic, psychological, pedagogical and sociological profile, there is a visible interest, from yesterday, but especially today for the consumption of prohibited substances, toxic, in their essence drugs and narcotics, a consumption phenomenon that was accentuated in the Romanian society after 1989. (Neacșu, 2010, 2019)

Psychosocial foundations of the adolescent behavior defined and studied institutionally in Romania by a national agency specializing in drugs (NAA), as well as NGOs that have an accepted status of experts in the field. Among the fundamental values promoted and converted in mission objectives, the following should be noted as more important (Duduciuc, A., Ivan, L., Chelcea, S., 2013);

- Chelcea (2013) describes the concept of collective self-esteem, for adolescent students. Among this age, the feeling of success/failure in a certain field, it feels as an indicator of global psychological selfefficacy

- The positive perception on one's own abilities and achievements configures a self-image consistent with that of the self, a kind of ideal picture

- New acquisitions and emotional-affective behavioural or thinking patterns identified, we find them informally in the subjects' answers, confirming the positive role they play due to the energetic potential of this age, which, however, comes with possible disadvantages, with relevant qualitative changes in behaviours adolescent subjects

- The new roles and positions that an adolescent can have in the evolution of integration in the proximate social. Usually the family or in the reference group (see Figure no. 2), also highlights an often stormy course of age-specific stages, such as rhythm, amplitude, intensity (usually higher), especially emotional-affective and behavioural-reactive manifestations; should be noted here as frequently highlighted the following, present in figure no. 2 below: 
Figure no. 2 Role characteristics specific to the evolution of adolescent behaviour

\section{"the adolescent seems to hate" - show rejection against family/ adults}

Less communicative

He comes home late

Unconventional entourage

Unconventional clothing style

- More accelerated social learning in adolescence, which has become a fundamental component of positive evaluations throughout life, contributes to the development and efficiency of the subject's personality in school, family and social life alike, registering an extraordinary dynamic in the stability of knowledge processes.

In the structure of learning at this age, we identify the following has characteristics that are more important:

- the relativity of the conception regarding the social importance of learning (the meaning of the answer);

- the quality of the associated motivations (psycho-socio-cultural status of the behaviour);

- stability of purposes (explicitly assumed and aware goals, objectives and tasks);

- the quality of the methodology and the operationality of the learning technologies (strategies, methods, techniques);

- access to material, energy, informational, relational resources);

- time management (duration and balance of planning/allocations);

- requested or personally created conditions (study climate);

- social, cultural, health, individual, group context, etc.;

- The value of school and extracurricular results correlated with the objectivity of the evaluation (personal and institutional standards).

Based on these structural elements we can establish connections, well-motivated transfers in order to capitalize on and optimize learning.
The different opinions and the relative consensus regarding the existence of a set of explicit and specific decomponents/mechanisms for school and academic learning have underlined by the dynamics of the formation of learning competencies (Neacșu, 2010, 2019). At their base are multiple sets of biological, neurological, neurodidactic, psychosocial and anthropological mechanisms.

The functional mechanisms of learning expressed under a wide variety of behaviors and validated by Neacșu, 2019 in the application of the multideterminist principle of interconditional subsidiarity.

\section{Research methodology}

\subsection{Purpose of the study}

In a $\mathrm{PhD}$ research that included four high schools in major cities in Romania, the evidences have aimed to investigate the lifestyle of adolescents during 20162019 (Colareza, 2020). The methods have used to determine the healthy or unhealthy lifestyle. Research uses an interdisciplinary methodology, and the dominant core of the approach is, in essence, the psycho-socio-pedagogical.

The purpose and objectives of this research are on the one hand, to identify and analyse correlations between generative behavioural factors, especially environmental, as risk factors. In addition, the analysis of the relationships between the personality characteristics of the subjects, such as gender, age and certain psychosocial characteristics such as will status, sociometric status in the reference group, quality of perception of group position, degree of selfknowledge, compositional values of lifestyle internalized and frequently outsourced.

\subsection{Methods of the research}

The research methodology consisted in constructing and applying two questionnaires, a cognitively structured interview:

- Questionnaire 1, dedicated to the lifestyle (negative, harmful factorial records), with 16 items with values measured on a five-step Likert-type scale, where 1 means total disagreement and $5=$ total agreement.

- Personal/personalized questionnaire with 24 items, aiming to express opinions on personal issues, such as moral attitudes, housing, family, community, income, social group personality, sensitivity to addiction issues, attitudes for or against the values of 
education.

- Cognitively structured interview

- Interesting are, to a large extent, the responses from focus groups, case studies, value items cut from biographical files prepared by counsellors, managers or significant value items observed and examined through the cognitive interview.

The focus of this paper is on unhealthy lifestyle (risky and addictive behaviors) in adolescents. The analysis of the power of the latent lifestyle variable, with its noxious limits, as well as of the attached indicators shows that the items included in this questionnaire demonstrate high intensity correlational values between the manifest variables $(r>0.725)$.

The common variation of the manifest variables resulted in the very high average variation of the only complex variable, latent but integrative at risk level, namely lifestyle, with very high percentages, of $89.2 \%$.

Factors with a significant impact added to the picture of risk behaviours such as: alcohol, smoking and the perception of the total unbalanced consumption of individually managed income. The literature abounds in studies that demonstrate a strong association between the income of the family or the adolescent and his school results (Mărginean, 2019).

The average scores calculated for the potentially risky behaviours investigated (see Table no. 2) indicate that smoking is the highest frequency behaviour: $\mathrm{M}_{\text {fumat }}=3.12$, St. dev. $=0.95$. In the same vein, the presence of an active network of influential friends does not per se represent a major risk behaviour but is not negligible one; interaction with the elderly seems beneficial.

At the gender level, the differences in average scores for this item are not statistically significant. The calculated values for the correlation coefficient $\rho$ (Spearman) outlines a picture of forces that act and shape the personality of the adolescent.

In order to be able to explain the actions and interactions of these vectors, we refer to the ecologicaltransactional model proposed by (Cicchetti and Toth, 1997). The referenced model explains that a person's environment is a multi-layered reality, in which the layers coexist and interact. Factors that act at the proximal level of the layer benefit from a stronger influence.
Structurally, the model starts from the individual level (micro), continues with the institutional level (meso), in which factors associated with the family, the community are integrated, and is completed with the systemic-structural social level (macro). Therefore, family dynamics, to which a certain socio-economic status is attached, is a frequently invoked variable, with strong modelling valences. Moreover, the quality of emotional and group life are certainly factors that influence the state of wellbeing and the perception of subjective happiness of adolescents today.

\section{Questions Research and their hypothetical vocation}

Interrogative statements can be multiplied. It could become interesting for future research and some questions that, although they have been given attention, still persist through the many white spots, trouble the world of specialists, parents, educators and public policy makers.

There are interesting perceptions, opinions and views on:

- To what extent is there a statistically significant correlation between the factors that define the adolescent's personality and the personal, social, existential problems that disturb their projects, expectations, certainties, balances, thus creating the minimum premises for the occurrence of addictive/risk behaviours in adolescents?

- Whether there is a statistically significant correlation between the matrix of socio-educational factors and the aggressive, socially inappropriate, unethical behaviours of adolescents?

- Whether there is a statistically significant correlation at a publicly manifested level of familygenerated or family-induced self-confidence patterns, reference groups, socio-educational factors, and noneducational, nonformative risk behaviour of adolescents or groups of adolescents today?

\section{Results}

The differences between the intellectual potential of the investigated adolescents, whose parents have only primary education $(\mathrm{d}=1.7)$ vs parents with university education, with values of course very differentiated, generating and effects, were analysed as a primary condition of knowing the forms of addictive behaviour significantly visible $(\mathrm{d}=1.4)$. 
Data on a number of statistical indicators for the items included in the questionnaire investigating harmful lifestyle behaviours in adolescents lead to a first remark, namely that a significant segment of the interviewed adolescents do not eat a hot meal a day and sleep less 6-7 hours a night. Although we do not have enough information for a significant number of adolescents to support this claim, we can identify behaviours of food risk or poor management of available time consumption.

Both chrono-biological aspects associated with sleep and general time planning/organization (more than $60 \%$ of the surveyed sample stated that they could not organize their time efficiently) and those related to diet can affect quality of life and learning ability.

Indeed, studies reviewed by Bertolini, (2011) which considers that adolescent period regarding the peculiarities of neurodevelopment shows a higher activity of the dopaminergic system and the immaturity of the serotonergic inhibitory system, which promotes impulsivity and the search for new sensations.

Other approaches (Stemate, C. C., Ulmeanu, C., E, 2018) to understanding voluntary behavior is to find specific actions that initiated from within the body under centralized control. Two other important features of voluntary behavior are planning (premeditation) and adaptation.

The data collected through the online questionnaire for adolescents' self-perceived addictions and perceptions of psychoactive substance use were some of the basic benchmarks that shaped the values with quality assessment status of the qualitative research project. Thus, they need to remember the following points by Colareza (2020):

- Average age of respondents: 19.6 years

- A percentage of $5-10 \%$ of the respondents declared themselves addicted to psychoactive substances

- The average age of the respondents who perceive themselves as dependent is 17 years

- Average age of subjects in the global sample who started smoking: 16 years;

- The average age at which the addicts started smoking, constituted in research as a subsample: 14.7 years
- A 10 percent of the respondents confess their dependence only on tobacco associated with coffee

- Among respondents who recognize the dependence on coffee, cigarettes and alcohol - 20\%

- Respondents who admit to the use of light drugs, in addition to coffee, cigarettes, alcohol - 10\%

- Among the respondents, only 12 accepte their psychologically dependence

- Those who declare themselves addicted, they accept their addiction only as physiological

- A percentage of 20 respondents admit that they are both psychologically and physiologically addiction reach.

This critic period promotes impulsivity and the search for new sensations. If this condition is generally transient, the direct effect of some drugs (alcohol, nicotine, cannabis, cocaine, opiates, gambling, cyber addiction etc) on the dopaminergic system (through an increase in dopamine release) can induce changes and promote certain long-term circuits that underlie addictive behavior (Bertolini, 2011).

Although there are some differences between the answers given by those who are only psychologically or only physically dependent, compared to those who are independent, the preliminary analysis of the data reveals an approach, which focused on two fundamentally dichotomous categories.

The European Drugs Report (2020) estimates prevalence rates among young adults between $3.5 \%$ in Hungary and $21.8 \%$ in France. In addition, the ratio among young people (men and women) who used cannabis in the last year is two to one. Among young people between 15-24 years, the prevalence of cannabis use is $18 \%$, higher then last year $9.3 \%$ (EMCDDA, 2020).

Thus, based on a selection from the database results the category of those who declare themselves psychologically and physiologically dependent on psychoactive substances and the category of those who declare themselves independent.

We present the data analytically (Table no. 1), introducing a first hierarchy of values. 
Table no. 1. Investigated risk behaviours - average scores

\begin{tabular}{lllll}
\hline & Min. & Max. & Mean & St. dev \\
\hline 5. I've been smoking for a while. & 1.00 & 4.00 & 3.13 & .95 \\
10. I have a network of friends who influence me. & 1.00 & 4.00 & 2.95 & 1.06 \\
8. I am sexually active. & 1.00 & 4.00 & 2.89 & .82 \\
12. I only get involved in activities that I enjoy. & 1.00 & 4.00 & 2.83 & 1.10 \\
14. I also have a nightlife (going out to the club). & 1.00 & 4.00 & 2.81 & .96 \\
4. I don't practice weekly exercise & 1.00 & 4.00 & 2.70 & 1.04 \\
15. I am rebellious, even aggressive. & 1.00 & 4.00 & 2.68 & 1.02 \\
9. I have relatively good school results. & 1.00 & 4.00 & 2.59 & 1.07 \\
11. I can't talk openly about my negative emotions. & 1.00 & 4.00 & 2.52 & 1.21 \\
3. I offer, but I do not receive affection on a regular basis. & 1.00 & 4.00 & 2.49 & .99 \\
7. My basic expenses are covered. & 1.00 & 4.00 & 2.33 & .90 \\
16. Some activities require approval (parent, legal guardian). & 1,00 & 4,00 & 2.21 & 1.07 \\
1. I eat at least once a day, but irregularly. & 1.00 & 4.00 & 2.20 & .97 \\
6. I have difficulty with my weight relative to my height. & 1.00 & 4.00 & 2.06 & .98 \\
13. I can't organize my time efficiently (disorganized). & 1.00 & 4.00 & 2.03 & 1.04 \\
2. I sleep less, less than 6 hours a night. & 1.00 & 4.00 & 2.02 & 1.10 \\
\hline
\end{tabular}

Tables no. 2 and 3 below show the average scores

The description of the characteristics that configure the behavioural and attitudinal profile of the two categories reveals differences, but also common characteristics, the comparative approach offering the premises for sketching an explanatory model, later validated by the analysis of the data in the interview. recorded by respondents who perceive themselves as psychologically and physiologically dependent vs. non-dependent. They appreciated the harmfulness of some psychoactive substances, to which they added sugar and energy drinks that, in turn, contain some psychoactive substances.

The evaluation scale of each item was also five intervals.

Table 2. Perceived harm of psychoactive substances - addicted adolescents

\begin{tabular}{|c|c|c|c|c|c|c|c|c|}
\hline tobacco & coffee & alcohol & cannabis & heroin & cocaine & LSD & Sugar & Energy drinks \\
\hline 3.70 & 2.09 & 3.44 & 2.68 & 4.61 & 4.30 & 4 & 3.01 & 3.203 \\
& & & & & & & & \\
\hline
\end{tabular}

Table 3. Perceived harm of psychoactive substances - independent adolescents

\begin{tabular}{|c|c|c|c|c|c|c|c|c|}
\hline tobacco & coffee & alcohol & cannabis & heroin & cocaine & LSD & Sugar & $\begin{array}{c}\text { Energy } \\
\text { drinks }\end{array}$ \\
\hline 3.77 & 2.12 & 3.41 & 2.69 & 4.59 & 4.37 & 3.96 & 2,85 & 3,200 \\
\hline
\end{tabular}

The results of research highlights following the analysis of partial data of the doctoral thesis (Colareza, 2020) on addictive and risky behaviour of adolescents.

Thus, resulsts show that 25 respondents who stated that they are both physiologically and psychologically addicted to psychoactive substances, 12 mentioned multiple addictions as tobacco, coffee, alcohol, drugs, 7 has addiction of tobacco, coffee, alcohol, 6 tobacco/coffee addictive alone are dependent only on coffee and 3, only on cigarettes). Of the addicts, only one does not smoke.
Therefore, for both psychoactive and non-addicted subjects, no drug is considered very strongly harmful (corresponding to the scale value 5); except coffee and much more harmful than sugar, cannabis has considered less harmful than all other drugs, and tobacco considered almost as harmful as LSD.

Many studies of national and european anti-drug agencies (NNA, EMCDDA) show most used drug is cannabis, (NAA, 2015) the prevalence of consumption being about five times higher than that of other substances. 
Some surveys conducted among students and the population general has provided an overview on prevalence of experimental and recreational consumption of drugs in Europe (EMCDDA, 2019).

In addition, the other depicts 61 respondents who state that they have no addiction; only two subjects do not consume any psychoactive substances at all, while most consume coffee and alcohol. About 16 of respondents, declared themselves in control/ nonaddictive but they consume moderately tobacco, coffee, alcohol, and light drugs are evaluated as having a recreational role/purpose.

Interesting to note is that among students opinion is more widely divided as to whether addicts lose some control, lose all control, or retain control, so compared to the addictive category, those in the category of nonaddicts a third (18) do not smoke.

Only five of the smokers declared themselves in full control even they uses only cigarettes with psychoactive substances, results shows most use at least three kinds of such substances.

Smoking is addictive to the greatest extent and, on the other hand, it is associated to the greatest extent with the consumption of other psychoactive substances.

Lack of smoking is a predictor of non-addiction, while being a smoker generates either the premises of the existence of at least one other addiction, or, for non-addicts, the premise of consumption or other psychoactive substances.

The entourage is the main environmental factor triggering the consumption of psychoactive substances. In most cases, smoking is the first contagion effect with the reference group.

The results of this exploratory study indicate the relevance of the need for further investigation of the elements that characterize a lifestyle harmful and harmful to adolescent health.

\section{Discussions \& Conclusions}

Adolescence is an intense period with positive feelings and turmoil whose frequency of change is relatively high, with less pleasant personal and social experiences, conflicts and periods of transition to normality quite long. Creativity and imagination reach high levels of nonconformist behaviour specific to adolescence, childhood interests are replaced by aspirations on training more outlined.
The analysis of the proposed hypotheses focuses on the influence of the models relatively assumed by adolescents, in the interaction especially with the reference groups in adopting behaviours that essentially shape an unhealthy lifestyle. They also involve the abuse of psychoactive substances, sexual behaviours; video games, gambling, risk, as well as anti-social behaviours associated with pathologies sometimes or even with surprising purposes (see pregnancies in adolescents between 15 and 17 years).

From the perspective of the Romanian educational and cultural environment, action strategies should be rethought to allow training in appropriate forms of movement and/or expression of the creative potential that today's adolescents have, with the small limitations generated by the health context (Covid-19 pandemic).

Today's education does not encourage the manifestation of these alternative variants or combinations thereof. An example is the school curriculum, rich in details, complicated, especially not systematized enough, still based on unmotivated models, focused on reproductive memory, less on the practical use, transfer and personal creativity of those learned. In addition, the cultural environment are not didactically, integrated or led based on the achievements of rhetorical art, science and digital, refusing the setting on voices, full of strong motivation, on the modernity of their contemporary offerings.

The research derives from the nature and complexity of the educational reality. So, specificity of inter and multidisciplinary study gets addictive and somewhat empathetic distant behaviour, as well as at European Union level,

Through this research, we open the way for the establishment of some fundamental points of an extended and deep pedagogical agenda, emphasizing its general, theoretical character, with not negligible similarities, as well as the descriptive and comparative character of the vast categorical concept of adolescents' lifestyle.

Due to the limitations of the online questionnaire interview, we focused only on the quantitative aspects of unhealthy lifestyle behaviours. However, the significant number of answers received $(\mathrm{N}=150)$ also allows a detailed analysis on certain dimensions of the analysed issue. The data collected through semistructured cognitive interviews provide an in-depth 
image generating the premises for building a logical model for relating these aspects of perceptual behavioural study, with personalized, individualizing, even family and social or adolescent group characteristics, as was the subject of our analysis.

The data on the opinions expressed by teachers during individual and group interviews are also of interest and have a strong confirmatory value associative with the risky behaviours and behaviours of the studied adolescents that we identified in the context of quantitative analysis. The qualitative analysis revealed a wealth of problematic aspects that do not represent an element of novelty at the level of the Romanian education system, still without relevant, correlative approaches.

One of these problems is absenteeism and school dropout. The factors we have previously exposed and discussed (family dynamics, socio-economic status of the family, the educational stock of the family, etc.) contribute to the understanding of the ways and power of influence of the formation and action of a context. Therefore, it acts unsupportive and restraining and which certainly significantly influences the quality of the learning process, its results and the impact on the personality of adolescent students. In relation to these behaviours, the interviewed teachers also identify a tendency to decrease the students' school performance.

Authors note: The authors had equal contributions to this article.

Corina Colareza holds a $\mathrm{PhD}$ in Educational Sciences, University of Bucharest, is director of the "Edu Bizim" Educational and Cultural Center in Bucharest. Psychopedagogue and speech therapist in supervision, graduate of Special Psychopedagogy, "Ovidius" University of Constanța, of the master's degree in Educational Management, at the Faculty of Psychology and Educational Sciences, University of Bucharest. Doctorate at the Doctoral School of the same faculty and university, with the theme "Lifestyle in adolescents. Motivations and training interdisciplinary strategies". Areas and centres of interest: psychopedagogy, counselling and speech therapy, preschool education. Complementary professionally is the field of dietetics and nutrition. Current focuses: knowledge and development of the harmonious personality of children and adolescents.

Ioan Neacșu is University Professor Emeritus $\mathrm{PhD}$ in the Department of Educational Sciences, Faculty of Psychology and Educational Sciences,
University of Bucharest. Graduate of the Faculty of Philosophy, University of Bucharest. Doctor in pedagogy, 1976. He has been leading doctoral students since 1992. He has held important managerial positions in MEC and faculty. He has published multiple papers and reference studies in prestigious publishing houses and well-known magazines. Centres of interest and areas of professional competence are: learning, learning styles, effective learning methods and techniques; the psychology of education; social pedagogy; total quality management in education; psychopedagogy of creativity, innovation and coaching; motor education; rural education; teacher training; emotional-affective education, learning neurodidactics, cognitive and metacognitive psychology.

\section{References}

NAA (National Anti-Drug Agency) (2015). Drug Studies, Research Report (vol. 3, issue 1). National study in schools on tobacco, alcohol and drug use, ESPAD 2015 (In Romanian).

Bertolini, M. (2011). Adolescence and addictions, Rev Med Switzerland 2011. vol $7 . \quad 1794-1798$, (https://www.revmed.ch/RMS/2011/RMS309/Adolescence-and-addictions) (In French).

Cicchetti, D., \& Toth, S. L. (1997). Developmental psychopathology. Perspectives on adjustment, risk, and disorder. New York, NY: Cambridge University Press.

Colareza, C. (2020). Lifestyle of adolescents. Motivations and training interdisciplinary strategies. Doctoral thesis, University of Bucharest (In Romanian).

Duduciuc, A., Ivan, L., \& Chelcea, S. (2013). Social psychology. Bucharest: Comunicare.ro Publishing House (In Romanian).

EMCDDA. (2019). European Monitoring Center for Drugs and Drug Addiction. European Drugs Report 2019: Trends and developments. Luxembourg: Publications Office of the European Union (In Romanian).

EMCDDA. (2020). European Monitoring Center for Drugs and Drug Addiction, European Drugs Report 2020: Highlights, Luxembourg: Publications Office of the European Union Available at: https://www.emcdda.europa.eu/system/files/publication s/13238 /TD0420439RON.pdf (accessed at 21.02.2021).

Iliescu R., \& Georgescu M. (2016), Life Quality Magazine, XXVII, no. 2, 2016, 161-169 (In Romanian).

Mărginean, (2020). Romanian Journal of Sociology, new series, year XXXI, no. 3-4, 143-158, Bucharest. (In Romanian) Available at: https://www.revistadesociologie.ro/sites/default/files/02 -imargineanb.pdf (accessed at 12.03.2021).

Neacşu, I. (2010). Social pedagogy: values, behaviors, experiences, strategies. Bucharest: University Publishing House (In Romanian). 
Neacşu, I. (2019). Neurodidactics of learning and cognitive psychology. Iasi: Polirom Publishing House (In Romanian).

Patrick, M. E., Maggs, J. L., \& Lefkowitz, E. S. (2015). Daily associations between drinking and sex among college students: A longitudinal measurement burst design. Journal of Research on Adolescence, 25 (2), 377386.
Siegel, D. (2014). The whirlwind of the mind. Bucharest: Herald Publishing House (In Romanian).

Stemate, C. C., \& Ulmeanu, C. E. (2018). Addictive behaviors in children and adolescents. Medical Practice Journal, 2018 vol. 13, no. 3 (59). (https://rjmp.com.ro/articles/2018.3/RJMP_2018_3_Art -04.pdf). (In Romanian). 


\section{Teaching Facilitators' Perceptions of the Contribution of Three Internship Workshops Models}

Vered Freedman, Constantin Cucoş 


\title{
Teaching Facilitators' Perceptions of the Contribution of Three Internship Workshops Models
}

\author{
Vered Freedman ${ }^{a^{*}}$, Constantin Cucoş ${ }^{b}$ \\ ${ }^{a}$ Gordon Academic College, Tchernichovsky 73, Haifa, Israel \\ ${ }^{b}$ Alexandru Ioan Cuza University, 11 Carol Boulevard, Iasi, Romania \\ *Corresponding author: veredf@gordon.ac.il
}

\section{Abstract}

\section{Keywords:}

Internship workshops; online model; 'incubator' model; facilitator; learning environment.
Internship workshops as part of induction to teaching in teacher education in Israel consist of three models: face-to-face, online, and 'incubator'. The article examines workshop facilitators' perceptions of workshops' contribution.

Mixed methods research included a questionnaire completed by 101 facilitators and statistically analyzed. Interviews were conducted with nine facilitators, three from each model and content and discourse analyzed. According to quantitative findings, no significant difference between workshop models and emotional support was perceived as stronger than professional support in all three models. Interview findings showed the clear presence of both emotional support and enhancement of a sense of self-efficacy. There were noticeable unique contributions in the two newer online and 'incubator' models, compared to the traditional face-to-face model implemented at the college. Both models promoted self-efficacy and emotional support, but each one relied on different strategies to provide the two types of contribution. In the online model, use of writing and connection with the facilitator promoted the contribution. In the 'incubator' model characteristics of the environment provided conditions for advancing support. The unique contributions have practical implications - workshops should integrate online and community-based components to promote interns' sense of well-being and professional competence as future teachers.

These findings may add valuable knowledge, which may help policy makers and interns themselves, to make better decisions on integrating the internship workshops within the prosses of teacher education.

\section{Zusammenfasung}

\section{Schlüsselworte:}

Praktikums-Workshops; Online-

Modell; 'Inkubator'-Modell;

Leiter; Lernumgebung.
Praktikumsworkshops als Teil der Einführung in den Lehrerberuf in der Lehrerausbildung in Israel bestehen aus drei Modellen: von Angesicht zu Angesicht, online und "Inkubator". Der Artikel untersucht die Wahrnehmungen der Leiter der Workshops hinsichtlich ihres Beitrags.

Die Mischmethodenforschung beinhaltete einen Fragebogen, der von 101 Leitern ausgefüllt und statistisch ausgewertet wurde. Mit neun Leitern, drei aus jedem Modell, wurden Interviews geführt und die Inhalte und der Diskurs analysiert. Den quantitativen Ergebnissen zufolge gab es keinen signifikanten Unterschied zwischen den Workshop-Modellen und die emotionale Unterstützung wurde in allen drei Modellen als stärker wahrgenommen als die professionelle Unterstützung. Die Ergebnisse der Interviews zeigten, dass sowohl die emotionale Unterstützung als auch die Stärkung des Selbstwirksamkeitsgefühls deutlich vorhanden waren. Es gab bemerkenswerte einzigartige Beiträge in den beiden neueren Online- und "Inkubator"-Modellen, verglichen mit dem traditionellen von Angesicht zu Angesicht Modell, das an der Hochschule implementiert wurde. Beide Modelle förderten die Selbstwirksamkeit und die emotionale Unterstützung, aber jedes verließ sich auf unterschiedliche Strategien, um die beiden Arten des Beitrags zu leisten. Im Online-Modell förderte die Verwendung von Schrift und die Verbindung mit dem Leiter den Beitrag. Im "Inkubator"-Modell boten Merkmale der Umgebung Bedingungen für die Förderung der Unterstützung. Die einzigartigen Beiträge haben praktische Implikationen - Workshops sollten Online- und Communitybasierte Komponenten integrieren, um das Wohlbefinden der Praktikanten und ihre berufliche Kompetenz als zukünftige Lehrer zu fördern.

Diese Ergebnisse können wertvolles Wissen hinzufügen, das Entscheidungsträgern und Praktikanten selbst helfen kann, bessere Entscheidungen über die Integration der Praktikumsworkshops in die Prozesse der Lehrerausbildung zu treffen.

\section{Introduction}

The stage of embarking on a professional career, largely known as 'induction' (Ingersoll \& Strong, 2011; Nasser Abu Alhija, Fresko \& Richenberg, 2011), is a time expressed in professional and personal difficulties that have been widely researched and discussed in the literature (Adoniou, 2016; Sözen, 2018). Various induction programs have developed over the years, where group sessions and personal mentoring 
constitute the key elements (Nasser Abu Alahija et. al., 2011; Hammer-Budnaro, 2018).

In Israel, induction programs consist of internship workshops, in which all teaching interns are required to take part (Paz \& Salant, 2012; Director General's circular, 2014). Traditional face-to-face (F2F) workshops are the most prevalent. However, online and 'incubator' workshops are two other models that have emerged in Israel and are implemented in the education system.

Empirical evidence on comparing these models is scarce. This article focuses on comparison of the three models. It presents findings of mixed method research, which examines workshop facilitators' perceptions of workshops' contribution.

\section{Theoretical background}

Internship workshops provide information about professional aspects of teaching, address dilemmas and challenging teaching situations, encourage professional reflective thinking, and formulate workable teaching patterns (Arviv-Elyashiv \& Lederer, 2011; Hammer, 2017). Based on interns' testimonies, professional contribution follows the main workshop's emotional contribution (Reingold, 2009; Fisherman, 2011). Interns have identified these workshops as a 'safe haven' in their first teaching year, a precious instrument in their emotional development (Levi-Keren \& Rosenberg, 2019; Bracha, in press). The key importance of these workshops pertains to the gap between theory and practice, a crucial factor leading to teachers' dropping out during their induction year (Adoniou, 2016; Shkedi, 2016).

The workshop models developed in Israel have similar goals and facilitation. They differ in the environment where communication among participants occurs, (F2F versus online environment) and the context where workshops are implemented (higher education institutions versus absorbing environment, i.e., school).

Online workshops emerged from the worldwide trend of Internet teaching and learning. It is conducted through discussions in forums and blogs. Online workshops' advantages include breaking time and space boundaries (Sela, 2010), the therapeutic value of writing as inviting introspection, expressing feelings and generating insights (Boniel-Nissim, 2010; Gilat, 2013) as well as decreasing one's sense of distress (Barak \& Boniel-Nissim, 2011; Kupferberg, 2013). Nevertheless, lack of self-management of learning and technological literacy may be burdensome for taking part in this model (Mioduser, Nachmias \& ForkoshBaruch, 2008).

'Incubator' model was developed to narrow the gap between the training process integration and assimilation into schools as well as to shine the spotlight onto adaptation and perception of schools as a system (Hammer, 2017). 'Incubators', existing in schools or teaching staff development centers, are linked to educational and ethical goals (Tzabary, Holzblat, Hachmon \& Pasternak, 2019; Bracha, in press) and are attended by interns, new teachers and mentor teachers. This emphasizes every role-holder's commitment to the needs of novice teachers and to paying full attention to factors promoting and hindering their success in the education system (Immanuel, 2017).

Despite the differences between the environments, there is still no broad basis of knowledge about the effectiveness of one model of workshop over the other (Rotenberg-Tadmor, 2014; Hammer-Budnaro, 2018; Levi-Keren and Rosenberg, 2019). It is important to note that these comparative studies have been limited to interns' perspective alone, and not to those of skilled facilitators leading these workshops (Zilbershtrom, 2013).

Workshop facilitators are mainly college lecturers, with an affinity to the world of counseling and treatment (Schatz-Oppenheimer, Mandel \& Zilbershtrom, 2014). Facilitators are those who are responsible for leading discourse with empathy, warmth and respect, honesty and acceptance (Yalom \& Leszcz, 2005), through confidence building debate. Similar to facilitators' significant role in F2F workshops, in online workshops, facilitators' presence has a secondary importance too. This derives from the need to compensate for the absence of their physical presence in the same space.

Further research is required in light of little knowledge gained regarding the comparison of these three workshop models, in order to gain better understanding of their effectiveness and contribution. Moreover, the search for empirical evidence on this issue, has become more important in this period. Due to the Korona crisis, all types of learning, including internship workshops, have gone online.

The current study compared the three models as seen by facilitators. Thus, it adds knowledge to help policy makers and interns reach better decisions 
regarding internship workshops in the framework of teacher education. Therefore, the research question is how facilitators perceive the contribution of internship workshops in three models, regarding emotional support, theoretical knowledge, practical tools and professional identity.

\section{Methodology}

Quantitative research participants included 101 facilitators (87 women and 14 men) from 20 Israeli teacher education colleges. A convenience sample represented facilitators from the three models $-58 \mathrm{~F} 2 \mathrm{~F}$, 26 online and 17 'incubator' model facilitators. 86\% Hebrew speakers, 9\% Arabic speakers and 5\% speakers of other languages. Qualitative research participants were nine workshop facilitators, three from each model, with at least two years' workshop facilitation seniority and rich educational background (experience $2-25$ years).

For the quantitative research, closed questionnaires for facilitators were distributed online after guarantee of complete anonymity. The questionnaire, developed for this study, addresses facilitators' perceptions towards the workshop's contribution in 12 areas (such as: Improving interpersonal communication, consolidating professional insights), to be marked from 1 to 6 . To examine general categories of the 12 areas, four aspects of the workshop's contribution (emotional support, theoretical knowledge, practical tools, and professional identity) were defined. Content was validated by expert judges and reliability was calculated using Cronbach's Alpha test.

Table 1: Reliability of the contribution of the workshop

\begin{tabular}{|l|l|c|}
\hline \multicolumn{2}{|c|}{ Category } & \multicolumn{1}{c|}{ Specific Area } \\
\hline Emotional support & Emotional support & 0.90 \\
& Expressing strengths and personal skills & 0.66 \\
\hline Theoretical knowledge & Disciplinary knowledge & Organizational knowledge \\
& Didactic knowledge & 0.72 \\
\hline Practical tools & Tools for professional coping & \\
\hline Professional identity & Improving interpersonal communication & 0.89 \\
& Improving self-efficacy to engage in teaching & \\
& Consolidating professional identity & \\
& Enhancing motivation for teaching & Consolidating professional insights \\
& Forming personal insights & \\
\hline
\end{tabular}

Since all reliability values are satisfactory, four measures were computed by averaging the responses to the areas included in each category.

For the qualitative research, online in-depth semi-structure interviews (Boyce \& Neale, 2006; Coolican, 2014) were conducted after interviewees signed informed consent forms. Interviews were flexible so as to allow focus on questions arising from facilitators' experiences. Questions referred to facilitators' views addressing the workshop's contribution to teaching interns, workshop components that affect the success of the workshop, and more. In addition to common questions, targeted questions were asked, such as how the online environment influenced the workshop's contribution to interns, the effect of location and group participants on the workshop's contribution to interns, etc. Interviews were recorded and transcribed.

\section{Findings}

Findings pertain to facilitators' perception of internship workshops' contribution in three models. The specific contributions were categorized into four domains: emotional support, theoretical knowledge, practical tools, professional identity. A two - way analysis of variance (MANOVA) was conducted to compare the three workshop models' perceived contribution. The results are presented in Figure 1.

Figure 1: Workshop Contribution by model and domain of contribution

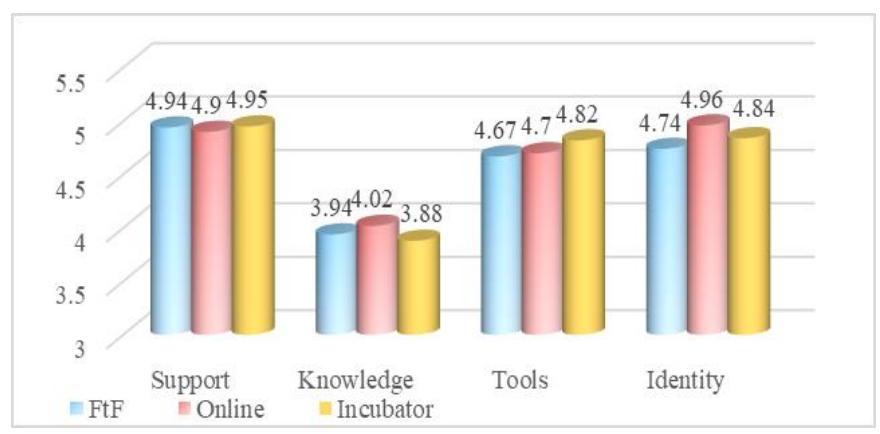


Workshop model did not yield a significant effect $(\mathrm{F}(2,97)=.10$, N.S. indicating that the general contribution score (mean of the four domains) was not significantly different in the three workshop models.

Furthermore, a significant main effect of domain was found $(\mathrm{F}(3,97)=45.99, \mathrm{p}<.001$. Post-hoc Bonferroni comparisons $(\mathrm{p}<.05)$ were conducted to identify specific differences among the four domains. The analysis revealed that workshop contribution in emotional support was significantly higher than in developing identity and providing tools, which was higher than the contribution to supplying knowledge. Thus, the hierarchy was: Support > Identity, Tools >
Knowledge. No significant interaction between workshop - model - domain were found, indicating that the hierarchy of domains was the same for all three models.

The qualitative analysis supported these findings and illuminated them more accurately. Interviews were analyzed according to grounded theory (Corbin \& Strauss, 2008) and followed by discourse analysis (Coolican, 2014). Two major types of contribution emerged: (a) psychological - expressed in providing emotional support and (b) professional - empowering the sense of self-efficacy. The two types of contributions with specific strategies and exemplary citations are presented in Table 2.

Table 2: Types of Contribution according to qualitative analysis

\begin{tabular}{|c|c|c|}
\hline Type of contribution & strategies & citations \\
\hline \multirow[t]{4}{*}{$\begin{array}{l}\text { Emotional support } \\
\text { (psychological contribution) }\end{array}$} & \multirow[t]{2}{*}{$\begin{array}{l}\text { Normalize personal } \\
\text { experiences }\end{array}$} & $\begin{array}{l}\text { They actually learn to identify the system and they come out of some sort of } \\
\text { bubble }\end{array}$ \\
\hline & & $\begin{array}{l}\text { They understand 'hold on, it is not only in my discipline'. It happens to } \\
\text { everyone }\end{array}$ \\
\hline & \multirow[t]{2}{*}{$\begin{array}{l}\text { Strengthen sense of } \\
\text { belonging }\end{array}$} & $\begin{array}{l}\text { The fact that they sit together in a group of people who are in the same } \\
\text { situation }\end{array}$ \\
\hline & & There is an atmosphere of togetherness and of genuine collegiate learning \\
\hline \multirow[t]{5}{*}{$\begin{array}{l}\text { Sense of self-efficacy } \\
\text { (professional contribution) }\end{array}$} & \multirow[t]{2}{*}{$\begin{array}{l}\text { Solution focused } \\
\text { discourse }\end{array}$} & $\begin{array}{l}\text { Understanding there is a solution is important. if not, they won't continue in } \\
\text { the system }\end{array}$ \\
\hline & & It's okay to fail, it's okay to cope and that in itself some sense of self-efficacy \\
\hline & \multirow{2}{*}{$\begin{array}{l}\text { Strengths focused } \\
\text { discourse }\end{array}$} & When sharing, the group is an echo for voices existing in him \\
\hline & & $\begin{array}{l}\text { The group's request to hear and give feedback awaken those of colleagues, } \\
\text { who are seeking resources within themselves }\end{array}$ \\
\hline & Practical knowledge & $\begin{array}{l}\text { He does not know what to expect ... when we ask and direct, it gives them a } \\
\text { strength }\end{array}$ \\
\hline
\end{tabular}

Both quantitative and qualitative analysis suggest that the contribution of the workshop is manifested in two major areas: emotional and professional contribution. Each one of these areas contains several dimensions.

Two categories emerged from the interviews regarding 'emotional support'. The first, normalizing personal experiences occurring on an intrapersonal level causing a change in interns' personal feelings. Metaphors chosen ('some sort of bubble in which they immersed themselves', 'breathing space'), reflect a sense of relief from a feeling of suffocation, which intensify the normalization. Strengthening sense of belonging is the second category, expressed by reinforcing links between individual interns and the group. Facilitators emphasized the important role of a group. Discourse analysis revealed metaphors ('thrown into the lion's den', 'in the same boat') contribute to understanding the unique meaning of strengthening the sense of belonging in interns' experiences of pressures and sense of danger. The message is that no intern is left to cope alone with challenges, but the entire group is recruited thus reinforcing each workshop participant's ability.

The second type of contribution emerged on the professional level - strengthening interns' sense of self-efficacy. It comprises of three strategies. The first strategy is participating in solution focused discourse. In workshop sessions, interns raised dilemmas and difficulties, and discourse emphasized finding solutions. The knowledge that it is possible, results in practical optimism and alleviates the transition from passivity to activity - a key aspect of educational work. The second strategy is focusing the discourse on strengths. Sharing and discussing professional dilemmas emphasizes interns' strengths. Often, when sharing experiences and an individual's ways of coping, the group echoes the voices the individual did 
not hear. The group's wish to hear all details, questions asked and feedback provided awakened both the individual intern's internal resources and those of colleagues, also seeking these resources within themselves. The third strategy is the acquisition of practical knowledge. Discourse and addressing issues from the world of teachers also contribute to a sense of professional self-efficacy, both by considering interns' professional duties and expectations and by planning and preparing for work stages throughout the year.

Interviews disclosed unique contributions of the newer workshop models. The online model particularly influenced self-efficacy. The discourse is documented and as such it is possible to process answers more profoundly and gain a better perspective on the process of professional development after the induction year. The other two models lack these advantages. Furthermore, time and place constraints invite profound communication between interns and facilitator. Although all models enable establishing contacts, only the online model offers structured access by using personal blogs. Online workshop facilitators testified that this sharing is different from the tasks that are open to all participants or the group's forum. This personal communication with the facilitator can promote self-efficacy and provides meaningful emotional support.

In the 'incubator' model, characteristics of the environment provide conditions for lending unique support. The model involves many factors engaging in absorbing interns into the education system, and as such provides varied ways of support. This contributes to interns professionally by promoting self-efficacy, and emotionally by creating a sense of protection. It does not occur among interns themselves or between facilitator and interns as in other models but among all role-holders who participate in 'incubator' sessions.

\section{Discussions}

This mixed-method research examined the contribution of internship workshops, which are part of interns' induction to teaching, by focusing on perspectives of facilitators in three workshop models: F2F, online, and 'incubator'.

Quantitative findings found no significant differences between the three models regarding their contribution to interns. Workshop contribution to emotional support was significantly higher than to developing identity and providing tools, which was higher than contribution to supplying knowledge.
These findings are supported by qualitative findings expressing emotional support and sense of selfefficacy. Hence, it can be said, that workshop contribution is emotional and professional. This claim is supported by the professional literature, emphasizing emotional support as workshops' main aim (Reingold, 2009; Fisherman, 2011) and indicating developing self-efficacy as a vital component.

Workshops' contribution to promoting a sense of normalization can be explained against a background of difficulties characterizing the process of induction to teaching. Research revealed that induction is experienced as a period of crisis, with components of shock and loneliness (Tzabar-Ben Yehoshua, 2001; Bar-Tal et al., in press;). Despite partnership and work relationships created in educational space, and although there are other interns in schools, there is no time or place to lay down one's hat and reveal personal experiences that are mostly normative and not unique to individual interns.

Promoting a sense of self-efficacy through workshops has been reported in previous studies (Rotenberg-Tadmor, 2014; Hammer-Budnaro, 2018), but in this study it is the mechanisms by which workshop processes enhance interns' sense of selfefficacy. Participation in discourse focused on solutions and strengths were found to be two of the ways intended to improve interns' self-efficacy.

While most studies conducted to date were based on interns' views, this study innovates what is known in the literature by presenting facilitators' voices and reflecting their perspectives. This strengthens the validity of workshops' contribution to teacher education in the two identified foci.

As well as factors common to the three models, there were unique contributions in the two newer online and 'incubator' models, compared to the traditional F2F model implemented at the college. Both models promoted self-efficacy and emotional support but relied on different strategies to provide the two types of contribution. Two interrelated assets of the online model were the use of writing and connection with the facilitator. Writing on a forum resembles an intra-personal discourse through which a person's inner voice is exposed to both writer and reader (Dickman, 2005). In addition, a cognitive advantage of writing is expressed by it helping organized and creative thought (Freedman \& Cucos, 2019) 
Another allegedly surprising finding is the meaningful connection with the facilitator. Indeed, accepted thinking is that the role of teachers in online learning is less dominant, but it turned out, that even in online workshops, learners need the full presence of facilitators as a source of support. This finding corresponds with studies that examined learners' expectations from teachers' presence in an online environment (Peacock et al., 2020; Reupert, Maybery, Patrick \& Chittleborough, 2010)

The unique contribution of the 'incubator' model results from the many factors responsible for absorbing interns into the education system. This is supported by previous studies on 'incubator' workshops (Levi-Keren \& Rosenberg, 2019) It does not occur in other models but is made up of all role-holders who take part in 'incubator' sessions. The study provides empirical support to the theoretical perception of 'incubator' workshops (Immanuel, 2017), which is consistent with the current perception of inclusion, community and integration of all systems.

The key finding indicating the emotional and professional contribution of each model is surprising in that the online model has been underappreciated compared to both F2F models. The expectation was that the online model would contribute less because F2F encounters are considered critical for workshop success. Congruent with previous comparative research findings (Hammer-Budnaro, 2018; Rotenberg Tadmor, 2014), this study suggests adopting the online model alongside the other two. Interestingly, online workshop constituted $20 \%$ of internship workshops as instructed by the Ministry of Education, but the COVID-19 crisis has expedited assimilation of the online model in the entire education system, including internship workshops. In addition to asynchronous learning, which has characterized the online model to date, the workshops were conducted during this period both in synchronous and asynchronous sessions, both online.

\section{Conclusions}

The online environment does not replace the F2F one but rather extends and complements possibilities. Mixed environments have been shown to generate greater satisfaction with learning than programs that are fully online (Cole et al., 2014), and that learners experience a greater sense of community than in traditional programs (Chen \& Chiou, 2014).
From a practical point of view, when planning interns' workshops, it is worthwhile integrating an online component and communication with community to promote interns' sense of well-being and their professional self-efficacy as future teachers.

Hence, there is also a response to the system's needs, saving physical resources without damaging the requirements of the internship workshop. The findings are likely to help identify interns suitable for each workshop model. Presenting the feature of each model to student teachers at the end of their $3^{\text {rd }}$ year, may contribute to their accurate impression of each.

This study was based on workshop facilitators. One limitation was that it looked solely at facilitators' perceptions. It is important to hear the opinion of interns to compare and examine consistencies between perspectives. Moreover, data was collected during workshops and therefore perspective is limited to immediate observations. It would be appropriate to explore a retroactive view allowing for learning about the long-term effects of all three workshop models' contribution to integration into teaching.

Authors note: The authors had equal contributions to this article.

Vered Freedman is a $\mathrm{PhD}$ student in education, with a Master's degree in educational counseling. Lecturer at the department of Early Childhood at the Gordon Academic College and facilitator of professional development workshops at the induction to teaching stage. Her areas of interest and research include online teaching, collaborative learning, and interpersonal communication. She is currently researching teaching internship workshops with an emphasis on learning environments.

Constantin Cucoş is a $\mathrm{PhD}$ Professor at the Faculty of Psychology and Educational Sciences (Department for Teacher Training), for over 30 years, at the "Alexandru Ioan Cuza" University of Iasi. He is the author of over 15 author volumes and over 200 studies in collective volumes or specialized journals. Areas of competence: training of trainers, philosophy of education, pedagogy of culture, religious education, aesthetic education, intercultural pedagogy.

\section{References}

Adoniou, M. (2016). Don't let me forget the teacher I wanted to become. Teacher Development, 20(3), 348363. 
Arviv-Elyashiv, R., \& Lederer, D. (2011). Internship Workshop - Mixed or Special, Dapim, 52, 46-71. (In Hebrew).

Barak, A., \& Boniel -Nissim, M. (2011). The Internet for the help of adolescents: Therapeutic value of blog writing. Mifgash, 34, 9-30. (In Hebrew).

Bar-Tal, S. Hemo, N. Snapir, Z., \& Gilat, Y. (In press). Choosing Education: challenges in Second Career Teachers' Induction to Teaching.

Boniel-Nissim, M. (2010). The Therapeutic Value of Adolescents' Blogging about Social-Emotional Difficulties. (Doctoral dissertation). University of Haifa, Israel. (In Hebrew).

Boyce, C., \& Neale, P. (2006) Conducting In-Depth Interview: A Guide for Designing and Conducting InDepth Interviews for Evaluation Input. Pathfinder International Tool Series, Monitoring and Evaluation-2

Bracha, E. (in press). Contribution of the Workshop Practice Based on Urban Hammama Model. Rav Gvanim - Mehkar VaSiach, Gordon Academic College of Education, Haifa, Israel. (In Hebrew).

Chen, B. H., \& Chiou, H. H. (2014). Learning style, sense of community and learning effectiveness in hybrid learning environment, Interactive Learning Environments, 22(4), 485-496.

Cole, M. T., Shelley, D. J., \& Swartz, L. B. (2014). Online Instruction, E-Learning, and Student Satisfaction: A Three-Year Study, International Review of Research in Open \& Distance Learning, 15(6), 111-131.

Coolican, H. (2014). Research Methods and Statistics in Psychology. New York: Psychology Press.

Corbin, J., \& Strauss, A. (2008). Basics of qualitative research: Techniques and procedures for developing grounded theory. London: Sage.

Dickman, N. (2005). Writing as a vehicle for reflecting and enhancing learning process of mathematics teachers in the course of becoming mathematics teachers' educators. (Doctoral dissertation). Technion, Haifa, Israel. (In Hebrew).

Director General's Circular (2014). Implementation Circular Towards the 2005 School Year - Teaching Internship. Jerusalem, Ministry of Education. (In Hebrew).

Fisherman, S. (2011). The novice's organizational literacy: school in the novice teachers' perception and as presented to them by the principal. In: O. SchatzOppenheimer, D. Maskit, \& S. Zilbershtrom (Eds.), Being a Teacher on the Induction Route. (pp. 151-180). Israel: Mofet. (In Hebrew).

Freedman, V., \& Cucoş, C. (2019). Model combining learning environments (online and face-to-face) in teaching internship workshops. European Proceedings of Social and Behavioral Sciences, Available at: https://www.researchgate.net/publication/342255576_ Model_Combining_Learning_Environments_In_Teachi ng_Internship_Workshops,

DOI: 10.15405/epsbs.2020.06.6.

Gilat, I. (Ed.), (2013). Only on the Internet Can I Share What I Am Going Through. Mental Help in an Online
Environment (pp. 100-114). Tel Aviv: Mofet. (In Hebrew).

Hammer, D. (2017). Leading Change Processes AcademiaField at the Induction: A three- Year Perspective. Hachinuch Usvivo, 39, 27-50 (In Hebrew).

Hammer-Budnaro, D. (2018). Online workshop versus face-to-face workshop during the induction phase. Dapim, 67, 161-183. (In Hebrew).

Immanuel, D. (2017). Teachers' incubator at the Induction to Teaching Stage retrieved from: http:/cms.education.gov.il/EducationCMS/Units/Staj/ Mitmahim/MeidaAlsadnaot/Chamamot.html.

Ingersoll, R., \& Strong, M. (2011). The Impact of Induction and Mentoring Programs for Beginning Teachers: A Critical Review of the Research. Review of Education Research. Vol. 81(2), pp. 201-233.

Kupferberg, I. (2013). Constructing online interpersonal communication through discourse resources. In I. Gilat (Ed.), Only on the Internet Can I Share What I Am Going Through. Mental Help in an Online Environment (pp. 100-114). Tel Aviv: Mofet. (In Hebrew).

Levi-Keren, M., \& Rosenberg, K. (2019). Novice Teachers' Perceptions towards the Induction Process: An Interim Report. Kibbutzim College of Education, Technology and the Arts (In Hebrew).

Mioduser, D., Nachmias, R., \& Forkosh-Baruch, A. (2008). New Literacies for the Knowledge Society. In J. Voogt \& G. Knezek (Eds.), International Handbook of Information Technology in Primary and Secondary Education (pp. 23-42). New York, NY: Springer.

Nasser Abu Alhija, P., Fresko, B., \& Reichenberg, R. (2011). The First Year of Teaching - an Overview. In O. Schatz-Oppenheimer, D. Maskit \& S. Zilbershtrom (Eds.), Being a Teacher on the Induction Route. (pp. 5587). Israel: Mofet. (In Hebrew).

Paz, D., \& Salant, A. (2012). Teacher Induction-Literature Review. Tel Aviv: Moet Institute (In Hebrew).

Peacock, S., Cowan, J., Irvine, L., \& Williams, J. (2020). An Exploration into the Importance of a Sense of Belonging for Online Learners. The International Review of Research in Open and Distributed Learning, 21(2), 18-35. https://doi.org/10.19173/irrodl.v20i5.4539.

Reingold, R. (2009). The Novice Teacher and Programs for Successful Absorption. Panim, 47, 79-85. Available from:

https://www.itu.org.il/?CategoryID=1544\&ArticleID=1 4146 (In Hebrew).

Reupert, A., Maybery, D., Patrick, K., \& Chittleborough, P. (2010). The importance of being human: Facilitators' personal presence in distance programs. International Journal of Teaching and Learning in Higher Education, 21(1), 47-56.

Rotenberg-Tadmor, Y. (2014). Enhancing Outcomes in Teacher Internship workshops: Comparing Face-toFace with Online Groups (Doctoral dissertation). University of Haifa, Haifa. (In Hebrew).

Schatz-Oppenheimer, O., Mandel, B., \& Zilbershtrom, S. (2014). Mentoring and Accompanying Interns and 
Novice Teachers. Jerusalem: Ministry of Education, Teaching Department - Induction and Internship (In Hebrew).

Sela, O. (2010) Can a virtual 'place' replace or enrich a physical place? Dvarim, 3, 123-134. (In Hebrew).

Shkedi, A. (2016). They remained in the Classroom: Narratives of Outstanding Teaching Students. Raanana: Mofet. (In Hebrew).

Sözen, H. P. (2018). Challenges of novice teachers. IJAEDU- International E-Journal of Advances in Education. IV (12), 278-282.

Tzabar-Ben Yehoshua, N. (2001) (Editor). Traditions and Genres in Qualitative Research Philosophies, Strategies and Advanced Tools. Mofet: Tel Aviv.
Tzabary, A., Holzblat, R., Hachmon, M., \& Pasternak, I. (2019, June). The expert in teaching was once a beginner: Talpiot's MIT research results. Paper presented at the 7th international conference on teacher education: The story of innovation in teacher education, Mofet Institute, Tel Aviv, Israel.

Yalom, I., \& Leszcz, M. (2005). The theory and practice of group psychotherapy (5th ed.). New York, NY: Basic.

Zilbershtrom, S. (2013). The policy of the Department of Internship and Induction in Teaching. In S. Shimoni \& A. Avidav-Ungar (Eds.), On the continuum: Training, induction and professional development of teachers policy, theory and practice (pp. 95-100). Mofet: Tel Aviv. (In Hebrew). 


\section{The Relationship Between the Emotional} Intelligence of a 21st Century Adult and His or Her Parental Competence

Andreea Șițoiu, Georgeta Pânişoară 


\title{
The Relationship Between the Emotional Intelligence of a 21st Century Adult and His or Her Parental Competence
}

\author{
Andreea Șițoiu ${ }^{a^{*}}$, Georgeta Pânișoară ${ }^{\mathrm{b}}$ \\ a Doctoral School "Psychology and Educational Sciences", University of Bucharest, 90 Panduri Road, District 5, Bucharest, 050603, Romania \\ ${ }^{b}$ Faculty of Psychology and Educational Sciences, University of Bucharest, 90 Panduri Road, District 5, Bucharest, 050603, Romania
}

*Corresponding author: andreea.sitoiu.20@drd.unibuc.ro

\section{Abstract}

Keywords:

emotional intelligence; parental competence; parenting.
According to Bar-On and Parker (2011) emotional intelligence is a set of skills that positively influences a person's ability to adapt to environmental requirements.

Parental competence is also defined as a function specific to parents, while also representing the style in which they fulfill their parental responsibilities. (Johnson et al., 2014)

The main purpose of this study is to identify the relationship between parents' emotional intelligence and parental competence.

The results obtained showed that parental competence does not depend entirely on the level of emotional intelligence of the parent. Following the distribution between the level of parental competence and the level of emotional intelligence, it was demonstrated that those parents who recorded a high score of parental competence (80-100 points), did not obtain the highest values of parental competence. Through the distribution of the values of the emotional intelligence coefficient according to gender, the female gender obtained higher values of emotional intelligence compared to the male gender.

The positive value of the Pearson correlation coefficient of 0.12 indicates that the level of emotional intelligence of adults positively influences the perception of parenthood in the form of a reward.

Emotional intelligence is also applicable in the field of parenting, helping to improve the perception of adults on the challenges encountered in the process of educating the child. This research provides new opportunities to investigate the impact that a parent's emotional intelligence and parenting skills have on a child's development.

Laut Bar-On und Parker (2011) ist emotionale Intelligenz eine Reihe von Fähigkeiten, die die Fähigkeit einer Person, sich an Umweltanforderungen anzupassen, positiv beeinflussen.

Die elterliche Kompetenz wird auch als eine Funktion definiert, die für die Eltern spezifisch ist und gleichzeitig den Stil darstellt, in dem sie ihre elterliche Verantwortung erfüllen. (Johnson et al., 2014).

Der Hauptzweck dieser Studie ist es, die Beziehung zwischen der emotionalen Intelligenz der Eltern und der elterlichen Kompetenz zu identifizieren.

Die erhaltenen Ergebnisse zeigten, dass die elterliche Kompetenz nicht vollständig vom Grad der emotionalen Intelligenz der Eltern abhängt. Nach der Verteilung zwischen dem Grad der elterlichen Kompetenz und dem Grad der emotionalen Intelligenz wurde gezeigt, dass diejenigen Eltern, die eine hohe Punktzahl der elterlichen Kompetenz (80-100 Punkte) verzeichneten, nicht die höchsten Werte der elterlichen Kompetenz erzielten. Durch die Verteilung der Werte des Koeffizienten der emotionalen Intelligenz nach Geschlecht erhielt das weibliche Geschlecht im Vergleich zum männlichen Geschlecht höhere Werte der emotionalen Intelligenz.

Der positive Wert des Pearson-Korrelationskoeffizienten von 0,12 zeigt an, dass der Grad der emotionalen Intelligenz von Erwachsenen die Wahrnehmung der Elternschaft in Form einer Belohnung positiv beeinflusst.

Emotionale Intelligenz ist auch im Bereich der Elternschaft anwendbar und trägt dazu bei, die Wahrnehmung von Erwachsenen in Bezug auf die Herausforderungen bei der Erziehung des Kindes zu verbessern. Diese Forschung bietet neue Möglichkeiten, um die Auswirkungen der emotionalen Intelligenz und der Erziehungskompetenz eines Elternteils auf die Entwicklung eines Kindes zu untersuchen.

\section{Introduction}

The main concepts of this study are emotional intelligence and parental competence. The literature and previous studies in the field of emotional intelligence and parental competence offer a wide range of definitions and explanations of the two concepts.

The concept of emotional intelligence finds its roots in the philosophy of Socrates, whose motto was 
"know yourself" (Goleman, 2018).

Parental competence is a system of knowledge, skills, abilities and skills supported by specific personality traits, through which the parent manages to successfully fulfill parental responsibilities, prevent and overcome crisis situations in order to develop the child. (Milcu, Griebel \& Sassu, 2008)

\section{Theoretical foundation}

\subsection{Emotional intelligence - theoretical and} practical aspects

Emotional intelligence is defined as a component part of social intelligence, involving the ability to monitor one's feelings and emotions, as well as the ability to discriminate between them. (Salovey, Brackett \& Mayer, 2007)

Bar-On characterizes emotional intelligence as a combination of abilities, skills and noncognitive skills, which influences a person's ability to adapt to the demands and pressures of the environment. (Bar-On \& Parker, 2011)

The components of emotional intelligence are: "self-awareness, social consciousness, selfmanagement, relationship management." (Goleman, 2016, p.8).

This type of intelligence is cultivated by parents who are followers of inductive discipline and availability for the child, therefore emotionally intelligent parents (Segrin \& Flora, 2019) there are no significant gender differences in the level of emotional intelligence. (Chohan \& Habib, 2020)

Elias (2019) formulates a series of specific principles of education based on emotional intelligence, referring to: awareness of the feelings of the parent, but also of those around, manifestation of empathy and understanding the views of others, gaining balance and resistance to emotional impulses and behavioral.

Parents' emotional intelligence plays a significant role in their psychological well-being and is also influenced by the parenting style adopted (Nguyen et al., 2020), positively determining the emotional behavior of their children. (Alegre, 2011) An increased level of intelligence emotional support of the parent, but also the support offered to the child determines the improvement of his emotional skills and resilience. (Basel \& Samara, 2019) At the same time a parenting style based on emotional intelligence will positively influence the child's level of emotional intelligence, but also his psychological health. (Olutope et al., 2019)

The parent who has acquired skills to regulate their own emotions is more likely to become constructively involved in childhood-specific emotional and behavioral disorders. This type of involvement determines the emotional self-regulation of the child. (Hajal \& Paley, 2020) On the other hand, a parent who is not able to understand and regulate his own emotions, manage his own stress and relate effectively to those around him will not be able to provide adequate support to the child. (Wamsler \& Restoy, 2020 by Brackett et al., 2010)

Emotional communication is important, although it is ignored in most parental interventions. (Shaffer, 2019) A study on this topic found that those young people who perceived their parents as offensive or avoidable, internalized these behaviors that they further used in resolving conflicts, also demonstrating the inability to express their feelings. Young people who perceived their parents as emotionally intelligent were able to resolve conflicts and express their emotions in a social way. (Martinez et al., 2019)

The usefulness of emotional intelligence is proven once again by models of emotion regulation that are largely influenced by the quality of interactions in early childhood. (England - Mason \& Gonzales, 2020)

2.2. Parental competence - theoretical and practical aspects

Vukusic (2018) defines parental competence as a system consisting of different behaviors of the parent, in order to support the child's development.

Parental competence is also defined as a function specific to parents, while also representing the style in which they fulfill their parental responsibilities. (Johnson et al., 2014) This involves adapting to the situational context, improving family life, developing self-confidence in caring for the child, motivation for caring for him, and achieving stability in difficult times. (Mohammadi et al., 2020)

This type of competence involves the use of strategies such as: child discipline, parental availability for his child, consistency and flexibility, reflection on reactions (Siegel, 2019), relationship based on communication (Ziglar, 2019), emotion training, coordination of children in the direction problem solving. (Gottman, 2018) Parental intervention strategies for child growth and development are also determined by parental stress, which in turn influences 
the quality of the parent-child relationship. (Weitlauf, Vehorn, Taylor \& Warren, 2012; Ngwoke, 2019 in McKenry \& Price, 2005)

The adult who has skills in the field of parenting demonstrates emotional and social intelligence manages to combine parental care and concern with the requirements for the child, formulated in accordance with his stage of development. (Segrin \& Flora, 2019)

In a study on social support for parents and the role of parental competence, it was shown that those adults who experience feelings of satisfaction and competence in parenting demonstrate constructive parental behaviors. (Yang \& Sun \& Gao, 2020)

Rejection in early adolescence and maternal criticism, respectively paternal rejection in middle adolescence causes emotional instability among adolescents, confirming the link between children's emotional development and family dynamics and the need for parental competence. (Lazaro et al., 2019)

The usefulness of parental competence and emotional intelligence of parents was also demonstrated in the study conducted by (Murphy, 2020 apud Grolnick, Frodi, \& Bridges, 2006) which found that balanced monitoring of the child and his encouragement by the parent during early childhood are associated with lower chances of problems with emotional and behavioral regulation.

\section{Research methodology}

\subsection{Problem statement}

The reunion of the two concepts around which the research activity is carried out, namely the emotional intelligence of parents, respectively parental competence, determines the purpose of this study: identifying the relationship between emotional intelligence and parental competence.

\subsection{Research hypotheses}

The fundamental paradigm of research is quantitative, aiming at an objective knowledge of the following two areas: emotional intelligence and parenting.

H1. Parental competence develops as the level of emotional intelligence increases.

H2. Females demonstrate a higher level of emotional intelligence compared to males.

H3. Parents with a high level of emotional intelligence consider parenting to be a reward.

\subsection{Purpose of the study}

The main purpose of this study is to identify the relationship between parents' emotional intelligence and parental competence. A second aim of the research aims to identify the level of emotional intelligence according to gender, respectively to establish the link between the level of emotional intelligence of parents and their perception of parent status.

\subsection{Research Methods}

\subsubsection{Subjects}

This study involved 144 respondents, of which 129 were female $(89.65 \%)$ and $15(10.4 \%)$ were male. The predominant age category of the respondents is 30-40 years, in number of $65(45.1 \%)$ followed by the category of $40-50$ years in number of $50(34.7 \%)$ of respondents, 17 respondents aged between 20 and 30 years $(11.8 \%)$, respectively 12 respondents over the age of $50(8.3 \%)$.

\subsubsection{Materials}

The present study is part of the quantitative paradigm, and the research method implemented for data collection is the indirect survey method. The instruments used are represented by two questionnaires adapted to the scale created by Jean Segal (2002) to measure the level of emotional intelligence and the scale developed by Gibaud-Wallston \& Wandersman (1978) to determine the level of parental competence. Both scales are characterized by an acceptable internal consistency: the scale for measuring emotional intelligence with an Alpha Cronbach value of 0.65 and the scale for measuring the level of parental competence with an Alpha Cronbach value of 0.53

Data collection was done using Google Forms. The research tools were included in a single two-part questionnaire. The first part aimed at measuring the level of emotional intelligence, while the second part aimed at determining the level of parental competence of respondents.

\section{Results}

The hypothesis that "Parental competence develops with increasing level of emotional intelligence" was tested through a distribution of the variables "parental competence" and "emotional intelligence", but also through a correlation between the two variables.

Following this distribution, it was demonstrated that those respondents who obtained scores higher than 
60 points also prove the highest level of emotional intelligence, followed by respondents with scores in the range of 80-100 points. From the data analysis, the hypothesis is refuted. At the same time, it is observed that those parents who obtained a score of parental competence between 80 and 100 points, have a lower frequency of the coefficient of emotional intelligence uncertain than those who obtained a score of parental competence higher than 60 points. (Table 1)

Table 1. Results of the distribution of the parental competence score according to the emotional intelligence coefficient

\begin{tabular}{|c|c|c|c|c|c|c|}
\hline \multirow{5}{*}{$\begin{array}{l}\text { Coefficient of emotional } \\
\text { intelligence }\end{array}$} & & \multicolumn{4}{|c|}{ The interval in which the parental competence score falls } & \multirow[b]{2}{*}{ Total } \\
\hline & & $<60$ & $>60$ & $=60$ & $\begin{array}{c}\text { Between } 80 \text { and } \\
100\end{array}$ & \\
\hline & Strong EQ & 8 & 30 & 8 & 26 & 72 \\
\hline & Low EQ & 6 & 27 & 5 & 8 & 46 \\
\hline & Uncertain coefficient & 2 & 17 & 1 & 6 & 26 \\
\hline Total & & 16 & 74 & 14 & 40 & 144 \\
\hline
\end{tabular}

Also, through the correlation between the emotional intelligence coefficient and parental competence, a negative correlation was obtained with the value of the negative Pearson of -0.14 which indicates that as the level of emotional intelligence increases, parental competence decreases. (Table 2)

Table 2. Pearson correlation results for emotional intelligence and parental competence

\begin{tabular}{|c|c|c|c|}
\hline & & $\begin{array}{l}\text { Coefficient of } \\
\text { emotional } \\
\text { intelligence }\end{array}$ & $\begin{array}{l}\text { The interval in which } \\
\text { the parental } \\
\text { competence score falls }\end{array}$ \\
\hline \multirow[t]{2}{*}{$\begin{array}{l}\text { Coefficient of emotional } \\
\text { intelligence }\end{array}$} & $\begin{array}{l}\text { Pearson Correlation } \\
\text { Sig. (2-tailed) }\end{array}$ & 1 & $\begin{array}{r}-, 145 \\
.083\end{array}$ \\
\hline & $\mathrm{N}$ & 144 & 144 \\
\hline The interval in which the & Pearson Correlation &,- 145 & 1 \\
\hline falls & $\mathrm{N}$ & 144 & 144 \\
\hline
\end{tabular}

To test the hypothesis that females demonstrated a higher level of emotional intelligence compared to males, the distribution of the emotional intelligence coefficient was calculated according to the gender of the respondent (Table 03). From the analyzed data it is observed that a strong coefficient of emotional intelligence was obtained mostly by female respondents. Assumption. in this case it is confirmed, but in order to establish exactly the validity of the hypothesis, a sample with a higher level of heterogeneity than that of the present study is needed.

Table 3. The results of the distribution of the emotional intelligence coefficient according to the gender of the respondents

\begin{tabular}{cccccc} 
& & \multicolumn{2}{c}{ Coefficient of emotional intelligence } & Total \\
& & Strong EQ & Low EQ & Uncertain & coefficient \\
gender of subjects & feminin & 63 & 43 & 23 & 129 \\
Total & masculin & 9 & 3 & 3 & 15 \\
\hline
\end{tabular}

The hypothesis according to which parents with a high level of emotional intelligence consider parenting to be a reward was confirmed starting from the distribution between the coefficient of emotional intelligence and the respondents' perception on the status of parent (Table 04). From the obtained data it is observed that the affirmative answers for the item regarding the respondent's perception on the parent status are offered by the respondents who obtained a strong coefficient of emotional intelligence. 


\begin{tabular}{|c|c|c|c|c|c|}
\hline & & Coeffic & of emotior & lligence & \\
\hline & & Strong EQ & Low EQ & $\begin{array}{l}\text { Uncertain } \\
\text { coefficient }\end{array}$ & Total \\
\hline & strongly disagree & 6 & 0 & 0 & 6 \\
\hline & somewhat disagree & 2 & 1 & 1 & 4 \\
\hline Being a parent is a reward for me & disagree & 2 & 2 & 3 & 7 \\
\hline Dening a pareint is a rewaru ior ine & agree & 25 & 18 & 4 & 47 \\
\hline & somewhat agree & 10 & 9 & 6 & 25 \\
\hline & strongly agree & 27 & 16 & 12 & 55 \\
\hline Total & & 72 & 46 & 26 & 144 \\
\hline
\end{tabular}

Also, the hypothesis was confirmed by the correlation between the emotional intelligence coefficient and the respondents' perception of the parent status. The positive value of the Pearson correlation coefficient of 0.12 indicates that the level of emotional intelligence positively influences the perception of parental status in the form of a reward. (Table 5)

Table 5. Pearson's correlation to the concept of parenting as a reward

\begin{tabular}{|c|c|c|c|}
\hline & & $\begin{array}{c}\text { Coefficient of } \\
\text { emotional intelligence }\end{array}$ & $\begin{array}{l}\text { Being a parent is } \\
\text { a reward for me }\end{array}$ \\
\hline \multirow{3}{*}{$\begin{array}{l}\text { Coefficient of emotional } \\
\text { intelligence }\end{array}$} & Pearson Correlation & 1 &, 122 \\
\hline & Sig. (2-tailed) & & , 146 \\
\hline & $\mathrm{N}$ & 144 & 144 \\
\hline \multirow{3}{*}{$\begin{array}{c}\text { Being a parent is a reward } \\
\text { for me }\end{array}$} & Pearson Correlation & 122 & 1 \\
\hline & Sig. (2-tailed) &, 146 & \\
\hline & $\mathrm{N}$ & 144 & 144 \\
\hline
\end{tabular}

\section{Discussions}

The present study aims to provide scientific information on the relationship between emotional intelligence and parental competence

The following aspects have been demonstrated: females demonstrate stronger emotional intelligence than males, parental competence does not depend entirely on the level of emotional intelligence of the parent, and the perception of parental status as a reward is found in the case of parents who have acquired skills specific to emotional intelligence. All the information discovered forms the basis for a possible further research that will take place on a larger sample.

The study has two important limitations: the first limit is represented by the low heterogeneity of the respondents, who are mainly female. An increased heterogeneity of the sample would have provided more diversified scientific information. A second limitation of the study is the research tool used to determine the coefficient of emotional intelligence. The scoring method involved obtaining equalities between the two coefficients, which further caused an uncertain coefficient of emotional intelligence in the case of 26 respondents out of 144. A further research will use an instrument for measuring emotional intelligence whose scoring not to be ambiguous.

\section{Conclusions}

In the context of new paradigms, the provision of rigorous information from a scientific point of view can determine the direction of training, improvement, respectively action of the parents of the 21 st century.

This study is the starting point for further research that will study the impact that the level of emotional intelligence of the parent, respectively his parental competence has on the development and behavior of the child.

Authors note: The authors have equal contributions to this article.

Andreea Sitcoiu is $\mathrm{PhD}$ student at the Doctoral School of Psychology and Educational Sciences of the University of Bucharest, University Assistant at the Faculty of Psychology and Educational Sciences, Transilvania University, Brașov. She is concerned with research in the following areas: emotional intelligence, parenting and education. 
Georgeta Pânișoară is Associate professor doctor in the Department of Psychology, Faculty of Psychology and Educational Sciences, University of Bucharest. Her specialized disciplines are: educational psychology, motivation psychology, human resource management, emotional development, verbal and nonverbal communication. Along with teaching these disciplines, she also contributed to the development of specialized literature specific to these fields. She is concerned with research in the following areas: organizational psychology and child development.

\section{References}

Alegre, A. (2011). Parenting Styles and Children's Emotional Intelligence: What do we know? The Family Journal, 19(1), 56-62. Available at: DOI: 10.1177/1066480710387486 (accessed at 21.11.2020).

Basel, E. K., \& Muthanna, S. (2019). The mediating role of trait emotional intelligence, prosocial behaviour, parental support and parental psychological control on the relationship between war trauma, and PTSD and depression. Journal of Research in Personality, 81, 246256. Available

at: https://doi.org/10.1016/j.jrp.2019.06.004 (accessed at 15.10.2020).

Brackett, M., Palomera, R., Kaja, J. M., Reyes, M. R., \& Salovey, P. (2010). Emotion - regulation ability, burnout, and job satisfaction among British secondaryschool teachers. Psychology in the Schools, 47(4), 406417. Available at: https://doi.org/10.1002/pits.20478. (accessed at 21.11.2020).

Chohan, S. H., \& Habib, H. A. (2020). A gender-based comparison: emotional intelligence in adolescents. Journal of Pakistan Psychiatric Society, 17(1), 30-33.

Elias, M. J., Tobias, S. E., \& Friedlander, B. S. (2019). Inteligența emoțională in educația copiilor. București: Editura Curtea Veche Publishing House.

England-Mason, G., \& Gonzalez, A. (2020). Intervening to shape children's emotion regulation: A review of emotion socialization parenting programs for young children. Emotion, 20(1), 98-104. Available at: https://doi.org/10.1037/emo0000638 (accessed at 15.12.2020).

Goleman, D. (2018). Inteligența emoțională. București: Curtea Veche Publishing House;

Gottman, J. (2018). Parenting. Cum să creștem copii inteligenți emoțional. București: Psychology Page Publishing House.

Grolnick, V., Frodi, A., \& Bridges, L. (2006). Maternal Control style and the mastery motivation of 1 - yearolds. Infant Mental Health Journal, 5(2), 72-82. Available at: DOI: 10.1002/1097-0355(198422)5:2<72: AID-IMHJ2280050203>3.0.CO;2-O. (accessed at 12.10.2020).

Hajal, N. J., \& Paley, B. (2020). Parental emotion and emotion regulation: A critical target of study for research and intervention to promote child emotion socialization. Developmental Psychology, 56(3), 403417. Available at: https://doi.org/10.1037/dev0000864 (accessed at 10.12.2020).

Johnson, B., Berdahl, L. D., Horne, M., Richter, E. A., \& Walters, M. (2014). A Parenting Competency Model. Parenting: Science and Practice, 14(2), 92-120. Available at: DOI: 10.1080/15295192.2014.914361 (accessed at 10.10.2021).

Lazaro, S. M., Leon-del-Barco, B., Polo-del-Rio, M. I., Tosina, R. Y., \& Ramos, V. M. L. (2019). The role of parental acceptance-rejection in emotional instability during adolescence. International Journal of Environmental Research and Public Health, 16(7), 1194. Available at: https://doi.org/10.3390/ijerph16071194 (accessed at 21.10.2020).

Martinez, P. L., Montero, D, M., Ruiz, D. M., \& Ferrer, B. M. (2019). The role of parental communication and emotional intelligence in child-parent violence. Behavioral Science (Basel), 9(12), 148. Available at: DOI: $10.3390 / \mathrm{bs} 9120148$ (accessed at 12.10.2020).

McKenry, P. C. \& Price, S. J. (2005). Families coping with change: A conceptual overview. In P. C. McKenry \& S. J. Price. Families and change: Coping with stressful events and transitions (3rd ed., 1-24). Thousand Oaks. CA: Sage.

Milcu, M., Griebel, W., \& Sassu, A. (2008). Cercetare psihologică modernă. București: University Publishing House.

Mohammadi, F., Rakhshan, M., Molazem, Z., Zareh, N., \& Gillespie, M. (2020). Development of parental competence scale in parents of children with autism. Journal of Pediatric Nursing, 50, 77-84. Available at: https://doi.org/10.1016/j.pedn.2019.04.006 (accessed at 22.12.2020).

Murphy, C. (2020). The feasibility of a universal socialemotional conscious discipline parent education curriculum training in the community setting. Published by ProQuest.

Nguyen, Q. A., Tran, T. D., Tran, T. A., Nguyen, T., \& Fisher, J. (2020). Perceived parenting styles and emotional intelligence among adolescents in Vietnam. The Family Journal, vol. 28 (4). Available at: https://doi.org/10.1177/1066480719896558 (accessed at 20.12.2020).

Ngwoke, A. N. (2019). Relationship among parental stress level, pupils' social competence and school adjustment in Engue State, Nigeria. The Educational Psychologist, 13(1), 355-367.

Olutope, A. E., Akpunne, B. C., \& Olajide, O. A. (2019). Parenting style, emotional intelligence and psychological health of Nigerian children. Asian Journal of Pediatric Research, 2(2), 1-11. Available at: https://doi.org/10.9734/ajpr/2019/v2i23010 (accessed at 10.12.2020). 
Segrin, C., \& Flora, J. (2019). Fostering social and emotional intelligence: What are the best current strategies in parenting? Social and Personality Psychology Compass. 13 (2). Available at: https://doi.org/10.1111/spc3.12439 (accessed at 22.12.2020).

Shaffer, A., Fitzgerald, M. M., Shipman, K., Torres, M. (2019). Let's connect: A developmentally - driven emotion - focused parenting intervention. Journal of Applied Developmental Psychology, 63, 33-41. Available at: https://doi.org/10.1016/j.appdev.2019.05.007 (accessed at 15.10.2020).

Sillick, T. J., \& Schutte, N. (2006). Emotional intelligence and self - esteem mediate between perceived early parental love and adult happiness. E-Journal of Applied Psychology, 2(2), 38-48. Available at: DOI: 10.7790/ejap.v2i2.71 (accessed at 21.12.2020).

Siegel, D. I., Bryson, T. P. (2019). Inteligența parentală. Disciplina dincolo de drame și haos emotional. București: Psychology Page Publishing House.

Vukusic, A. M. (2018). Self-evaluation of Parental
Competence - Differences Between Parents with Pedagogical and Non-Pedagogical Professions. World Journal of Education. 8 (2), 1-9.

Wamsler, C., \& Restoy, F. (2020). Emotional intelligence and the sustainable development goals: supporting peaceful, just and inclusive societies. In Peace, Justice and Strong Institutions. Available at: DOI: https: //doi.org/10.1007/978-3-319-71066-2_123-1 (accessed at 22.12.2020).

Weitlauf, A. S., Vehorn, A. C, Taylor, J. L., \& Warren, Z. E. (2012). Relationship satisfaction, parenting stress, and depression in mothers of children with autism. National Autistic Society, 18(2), 194-198. Available at: https://doi.org/10.1177/1362361312458039 (accessed at 15.10.2020).

Yang, X., Sun, K., \& Gao, L, L. (2020). Social support, parental role competence and satisfaction among Chinese mothers and fathers in early postpartum perios: A cross-sectional study. Women and Birth, 33(3), 280285.

Ziglar, Z. (2019). Putem crește copii buni într-o lume negativă. București: Curtea Veche Publishing House. 


\section{Experiential Learning and Curriculum for} Romanian Primary School Education in the Fundamental Acquisition Stage

Dorina Grigor, Benjamin Frentsos 


\title{
Experiential Learning and Curriculum for Romanian Primary School Education in the Fundamental Acquisition Stage
}

\author{
Dorina Grigor ${ }^{a *}$, Benjamin Frentsos ${ }^{b}$ \\ ${ }^{a}$ Doctoral School "Education, Reflection, Development”, Babes-Bolyai University Cluj-Napoca, 7 Sindicatelor Street, 400029, Romania \\ ${ }^{b}$ Montana State University Extension, Bozeman, USA \\ *Corresponding author: dorina.grigor@yahoo.com
}

\section{Abstract}

\section{Keywords:}

experiential learning; primary school curriculum; key competencies; the primary school students' profile.
"No one left behind" is the main idea that the European Union operates on these days. Each person is extremely important; he or she comes with a valuable background. The educational system must help each individual to develop knowledge, abilities and attitudes so that at the end of an educational curricular cycle, he/she is able to successfully self -integrate into the next educational level or stage in life to become the graduate prepared to easily adapt to life. The Curriculum for Romanian primary school has gone through a significant evolution and, thus, it includes activities based on eight key competencies that express themselves in students' learning. In particular, we refer to learning by experience, learning by reflection, learning by conceptualization, learning by generalizing and about experiential learning. We have to focus on creating and delivering content to students with individualized profiles so they are ready to lead a productive, healthy life, and to be prepared to adapt themselves to the challenges in life whenever necessary.

\section{Zusammenfasung}

\section{Schlüsselworte:}

Erfahrungslernen; Lehrplan der Grundschule;

Schlüsselkompetenzen; Profil des Grunschulabsolventen.
"Niemand zurückgelassen" ist die Hauptidee, die die Europäische Union in diesen Tagen betreibt. Jeder Mensch ist extrem wichtig; er oder sie kommt mit einem wertvollen Hintergrund. Das Bildungssystem muss jedem Einzelnen helfen, Kenntnisse, Fähigkeiten und Einstellungen zu entwickeln, damit er sich am Ende eines Lehrzyklus erfolgreich in die nächste Bildungsstufe oder Lebensphase integrieren kann, um der Absolvent zu werden, auf den er vorbereitet ist leicht an das Leben anpassen. Das Curriculum für die rumänische Grundschule hat eine bedeutende Entwicklung durchlaufen und umfasst daher Aktivitäten, die auf acht Schlüsselkompetenzen basieren, die sich im Lernen der Schüler ausdrücken. Insbesondere beziehen wir uns auf Lernen durch Erfahrung, Lernen durch Reflexion, Lernen durch Konzeptualisierung, Lernen durch Verallgemeinern und über Erfahrungslernen. Wir müssen uns darauf konzentrieren, Inhalte mit individuellen Profilen für Schüler zu erstellen und bereitzustellen, damit diese bereit sind, ein produktives, gesundes Leben zu führen und bereit zu sein, sich bei Bedarf an die Herausforderungen im Leben anzupassen.

\section{The need to activate experiential learning in school}

Students need to be involved, heard, seen and understood. They need to take an active role in the educational process, and to learn by experience. Experiential learning is the appropriate field of students' development that fulfills their needs in this way. The Curriculum for Romanian primary school, that was edited in 2013, offers a new integrated vision over the teaching process and includes certain aspects of experiential learning.

In The Praxiologic Dictionary of Pedagogy. Volume III (Dicționar praxiologic de pedagogie. Volumul III), experiential learning has a complex definition: "Type of learning centered on the learner's needs and desires; it unfolds starting from significant personal direct experiences, in real contexts, of the subject of learning, experiences that generate the need of understanding and that are evaluated as learning occasions (the person learns by his/her experience)." (Bocoș, coord., 2017, p.42).

The emblematic researcher/scientist that spoke about experiential learning, David Kolb, in 1984, explained that experience by itself is not enough to learn. We need the other steps that complete the process and personal experience ensure "life, texture and subjective personal meaning to abstract concepts" (Kolb, 1984, p. 21). It is a complex process that is circular and holistic, implying use of one's hands, the head and heart in order to have a healthy mind. The four steps in David Kolb's model are:

- Concrete experience 
- Reflective observation

- Abstract conceptualization

- Active experimentation.

According to Mușata Bocoș’ praxiological dictionary "practicing experiential learning and its outcomes stimulates the reflection over individual's own actions and learning motivation, the steps towards experiential conceptualization, active experimentation, the use of acquired acquisitions through experience in new contexts (they generate desirable experiences), enhancing the self-control in the learning process." (Bocoș et. al, 2017, p. 42).

\section{Experiential learning and Curriculum for Romanian primary school, critical analysis, past and future}

For the Romanian primary school students, when we speak about learning and experiential learning, we have to mention the learner's environment, the connections that he has with his family, with his neighborhood, his peer community and society. The fact that in such a learning context he experiences before being told or shown so, then he shares steps when he describes his experience and reaction, he talks about what was most important about what he did, he relates the life skill practiced to his own everyday experiences or he shares how he will use what he has learnt, his life skill practiced in other parts of his life. We found part of the four-stage cycle in Curriculum for Romanian primary school, mostly in the curriculum that was published in 2013 when the educational system was organized in a complex way as based on eight fundamental elements, on eight key competencies that are "adequate benchmarks for European educational system towards the knowledge society"

(https://formare.educred.ro/resurse/CRED_P_M11_C ompetentele_cheie.pdf, p.4.) and the pupil is prepared to set up long life learning tasks. School doesn't prepare students for a job, it has to prepare them for life, ready to adapt their skills in order to have a comfortable adult life.

Therefore, in this study we decided to analyse the vision, from the experiential learning perspective, between old curriculum that was published in 1998, National Curriculum - School programs for primary school education (Curriculum Național - Programe școlare pentru învățământul primar) and the new one National Curriculum - Current school programs (Curriculum Național - Programe școlare în vigoare) published in 2013 on the Romanian national educational website http://programe.ise.ro/).

In the old document, as we studied it, we could read about competencies, but they are described separately for each discipline and they were expressed through general objectives and reference objectives. There we could find only activities that needed action, concrete experience. There was no reference to reflective observation, conceptualization, active experimentation/sharing, processing, generalizing and applying. When we searched examples of experiential learning in the whole document, for maths discipline we could find "that much more important are the activities of problem solving through trial-and-error, finding the solutions that are within the strict learning framework" and the teacher "facilitates the learning" (Curriculum Național, 1998, p. 87). Within the science curriculum important concepts included: "using and integrating the new information in the knowledge that student already knows from his personal experience" (Curriculum Naţional 1998, p. 115) and "expressing conclusions as a result of some personal experiences that were conducted in the class or in the close environment" (Curriculum Naţional,1998, p. 120). We still found an expression such as "executing experiences using familiar instruments" (Curriculum Naţional, 1998, p. 125). For the geography discipline we found an emphasis on activities that took place exclusively in the middle of the nature through the direct contact with the studied object, matter and through the method "learning from experiencing" (Curriculum Naţional, 1998, p. 147).

\section{Experiential learning and the actual Curriculum for Romanian primary school, new approaches}

In the Romanian National Curriculum - Current school programs (Curriculum Naţional - Programe școlare în vigoare) from 2013, we discovered that there is a focus on three dimensions. The first is the manifestation of autonomy, through: a) affirming or defending personal needs, rights, responsibilities, interests or limitations, b) developing personal projects, c) the ability to take action in the big picture. Additionally, it is focused on interactive use of intellectual instruments through using interactive texts, symbols, language, knowledge or new technology. The third dimension is about working in heterogeneous groups developing relationships, cooperation, collaboration and conflict management. Therefore, the purpose is that school should offer an European training profile based on eight key 
competencies: 1. Communicating in the mother language 2. Communicating in foreign languages 3. STEM (science, technology, engineering, mathematics) 4. Digital competencies 5. Learning to learn 6. Social and civic competencies 7. Sense of initiative and entrepreneurship 8. Cultural awareness and expression (Recommendation of the European Parliament and of the Council on Key competences for lifelong learning, 18 Dec. 2006, 2006/962/EC).

We see these key competencies as learning results, namely an ensemble of knowledge, abilities and attitudes that are to be developed for all our students, as tools for relevant learning. As we don't elevate individual academic subjects by themselves, they are not being taught as separate, distinct fields of study, but rather they are integrated into two or more disciplines in an educational course. Each domain integrates academic perspectives through some disciplines that were familiar in the traditional curriculum, for example mother tongue or foreign language, maths or science. What we discover is that a number of classical disciplines are actually gathered in the structure of the curriculum, personal development or civic education. These eight competencies are fulfilled at the reunion of other educational paradigms, offering them inter and transdisciplinary perspectives.

For the first key competency, knowledge refers to vocabulary, language functions, verbal interactions, literary and non-fiction texts. These make up the main features of different styles of language. The abilities refer to collecting, processing the information, using useful resources, saying or writing oral arguments. Evaluating the aesthetic qualities, understanding the impact of the speech over the others and the need to understand and use the language in a proper way are the components of the first key competence.

In our opinion, as the European Union demands and also the students' needs move towards learning from experience and developing knowledge, abilities and attitudes, we adapted Kolb's cyclic model of experiential learning so that for each step of the circular teaching process the primary school teachers should integrate them into their teaching. We have to be aware of every step in this complex process and associate it with those three landmarks.

Figure 1. Kolb's Learning Cycle with the involved landmarks for each domain in acquiring the key competencies Source: adapted after Kolb (1984, p. 33)

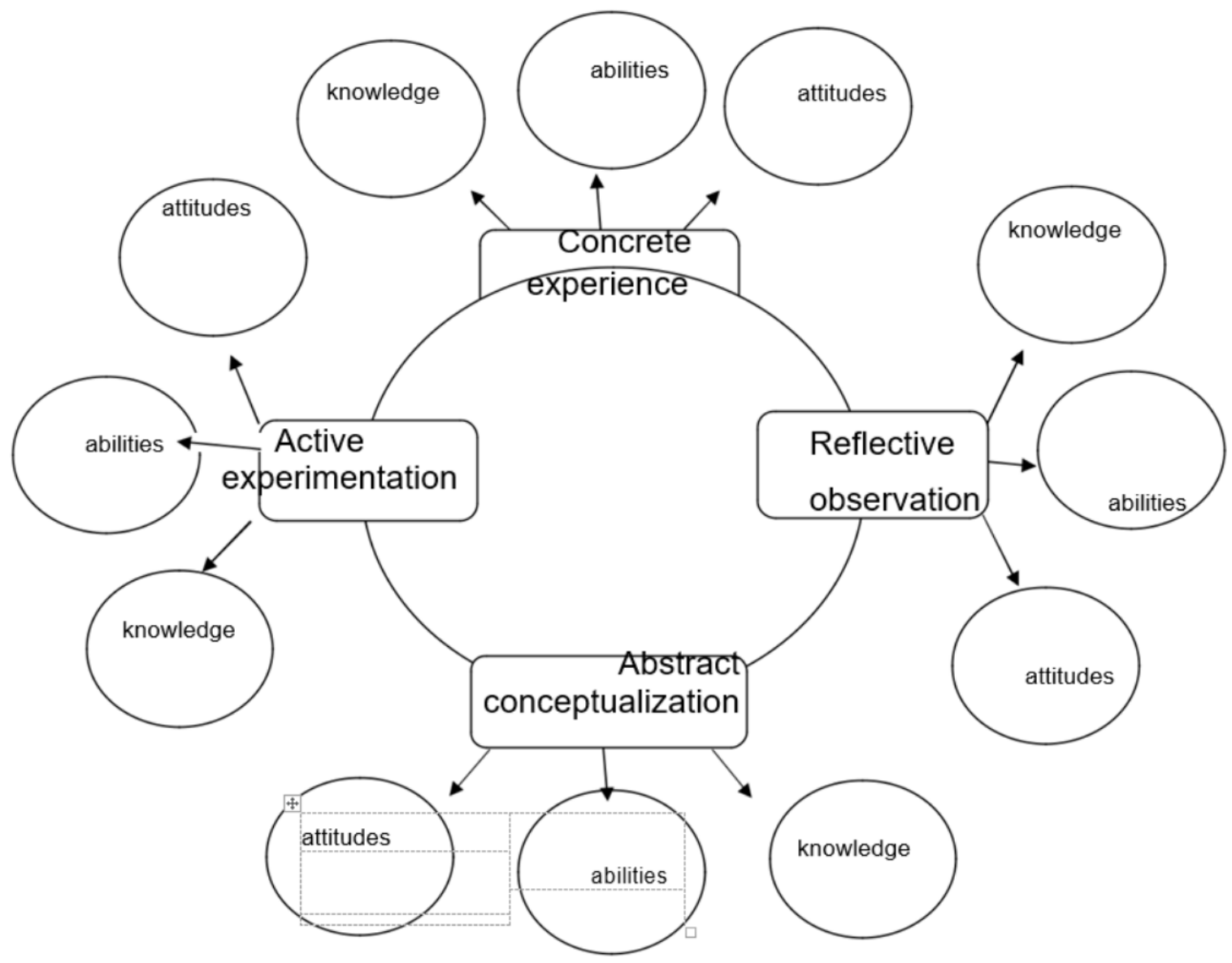


In the newest version of the curriculum for Romanian primary school education, that was published in 2013, as we looked for experiential learning examples and outcomes in the document, we noted that there was a significant change in this perspective. So, the curriculum is based on a new model of project-based competencies in order to fulfill the students' needs and to provide the proper formation of the Romanian primary school student. Those competencies are in deep relationship with the eight key competencies that we mentioned above, they underline the purpose of relevant learning and the action dimension in creating the students' personality. More than that, they are formed by the learning -based knowledge, abilities and attitudes and they allow problem solving in one domain or general problems in different contexts.

As starting with the school year 2013, the Romanian primary school system was enriched with the addition of a preparatory class. We have now five years of schooling instead of four in primary school. In the first year, the focus is on learning through games. "The actual curriculum prioritizes a studentcentered, active learning approach. The curriculum notes that learning is not a passive process that occurs in students' lives, but it is a personal experience they have to take part in." (http://programe.ise.ro/Portals/1/2013_CP_I_II/01_C LR_CP_II_OMEN.pdf, p.2).

The curriculum for Romanian primary school is separated in two subsections that are related to the curricular cycles. Preschool education, the first three classes, the preparatory class, the first class and the second class belong to the fundamental acquisition stage (ciclul achizitiilor fundamentale). The third form through the sixth form together with secondary school belong to the development stage (ciclul de dezvoltare).

In primary and elementary school, the study of mother tongue, at the curricular area Language and communicating (Limbă și comunicare), the discipline Communicating in Romanian language (Comunicare in limba română) lasts till the end of the second form and ensures an evolution of the competencies by evaluating the experiences that are specific to this period and by creating significant learning contexts for real life. Everybody learns better if he or she understands why he or she learns the learning content.

For the development cycle the discipline is named Romanian language and literature (Limba și literatura română) and it is scheduled and organized according to Common framework for the development of communication skills in the mother tongue (Cadrul comun pentru dezvoltarea competentelor de comunicare in limba maternă,) that was developed in 2014 as a result of the POSDRU 35279 research $A n$ efficient education based on informed decisions Strategies for capitalizing on international assessments of learning outcomes (Un învăţământ performant bazat pe decizii fundamentate - Strategii de valorificare a evaluărilor internaţionale privind rezultatele invăţării). International research such as PISA or PIRLS established a set of identical processes for measuring students' learning in reading acquisition, without considering their mother tongue.

This methodological approach suggests that for receiving oral or written messages students should follow the four steps that are connected to experiential learning steps. These include: identifying clearly explained information, producing simple deductions, integrating and sensing the meaning of ideas or of the information, critically evaluating the content or the textual particularities. LiFT - Literary Framework for Teachers (Cadrul de referință pentru literatură) valuates European didactic experience and is interested in creating a positive attitude towards finding the world through the process of reading.(http://programe.ise.ro/Portals/1/Curriculum/ 2014-12/01-

Limba\%20si\%20literatura\%20romana_clasele\%20a \%20III-a\%20-\%20a\%20IV-a.pdf, p. 12 )

We decided for this paper to identify experiential learning approaches in the first subsection-The fundamental acquisition stage for all the curricular areas. This way we shall go on with the study of Maths and science area (Matematică și științe ale naturii) and for the discipline Maths and exploring the environment (Matematică și explorarea mediului) we found that the evaluation process will insist on recognizing the learning experiences and the students' acquired competencies in non-formal or informal contexts. "Contextualizing learning by referring to the surrounding reality increases the depth of understanding of the concepts and the used procedures"

(http://programe.ise.ro/Portals/1/2013_CP_I_II/25_M atematica_explorarea_mediului_CP_II_OM EN.pdf, p. 27).

For the Art. Technology area (Arte. Tehnologii), the discipline Visual arts and practical abilities (Arte vizuale și abilități practice) gives some examples of 
learning activities that "value the student's concrete experience, integrating appropriate teaching strategies to different learning contexts", those examples of learning activities are proposed for guiding teachers only. Inside this discipline, educators and students can create various connections between other disciplines, it can be easily create a significant learning context for real life, for example writing, mathematical operations, awareness of beauty that surrounds us, personal development (http://programe.ise.ro/Portals/1/2013_CP_I_II/37_A VAB_CP_II_OMEN.pdf, p.2).

Within the area Advice and Guidance (Consiliere și Orientare), Personal development (Dezvoltare personală) is included. The aim of this discipline is to develop "students' capacities of self -knowledge and of expressing their interests in a positive way, attitudes, personal feelings, abilities to relate and communicate reflections over learning. First of all, this discipline forms abilities and develops attitudes, with the purpose to gain pupils' self -confidence, well being, to prepare them for life and for the future" (http://programe.ise.ro/Portals/1/2013_CP_I_II/37_A VAB_CP_II_OMEN.pdf, p.2). This document was developed in accordance to the international recommendation of the European Council in the two Resolutions (2004,

2008 , http://register.consilium.eu.int/,

http://register.consilium.europa.eu/). As this document says when students authentically learn, there is a relationship between what they think, what they feel and how they behave. "A special attention is accorded to exploring interests, to applying learning abilities, to identifying previous experiences and being aware of students' expectations related to the activities that are intended to develop." (http://programe.ise.ro/Portals/1/2013_CP_I_II/55_D ezvoltare\%20personala_CP_II_O MEN.pdf, p. 11).

In our opinion here we can find the most appropriate example for what we are looking for: students are supposed to experience, then they express their feelings about what they have experienced or discovered, they reflect together over the individual or collective products, over their own progress, they evaluate the results offering each student feedback, then they analyze the experience. Using this model, students can involve their parents, other teachers or students, and the community in the next steps. The teacher's role in this process is to organize and offer learning and gaming opportunities that allow students to discover and experience their own abilities and attitudes, to customize and facilitate their transfer of knowledge into real life. This discipline implies students' direct involvement. There are some questions that relate to teaching with this model: What I liked best ...? What I disliked ...? What have I learnt ...? What will I use ...? for the learning experiential process

(http://programe.ise.ro/Portals/1/2013_CP_I_II/55_D ezvoltare\%20personala_CP_II_OM EN.pdf, p. 12).

\section{Conclusions}

With this paper we wanted to underline the importance of practicing experiential learning for Romanian primary school students, this time from the fundamental acquisition stage, in order to provide an educational process that is appropriate to students' realities, their environment, their connections with all that surrounds them including family, neighbors and community. Primary school teachers have to study the curriculum at the beginning of the school year. This document has to be their instrument leading them to creating a better educational experience. Educators can improve their teaching and their students' lives. We searched the old document Romanian National Curriculum - School programs for primary school education, 1998 (Curriculum National - Programe şcolare pentru învățământul primar, 1998) and there were only few resources and few examples of experiential learning. In the newest document, Romanian National Curriculum - Current school programmes, 2013 (Curriculum Național-Programe scolare $\hat{i n}$ vigoare, 2013) we found much more material that is directly related to experiential learning. Experiential learning activities are supposed to be incorporated into formal education An educational system may also enrich its teaching and learning with non-formal experiential educational based activities or, why not, informal ones. Experiential learning involves life long, continuous learning and we strongly believe that "practicing learning according to real life, being part of real experience, of trying, is a social skill and necessary, until the end of time" (Bocoș et al., 2017, p. 42).

Authors note: The authors have equal contributions to this article.

Dorina Grigor is a primary school teacher at Colegiul Naţional Pedagogic "Regele Ferdinand, in Sighetu Marmaţiei and Ph.D. Student at "Education, Reflection, Development" Doctoral School, BabesBolyai University, in Cluj-Napoca, Romania). Her research areas are oriented towards investigating the 
formative impact of experiential learning activities carried out in non-formal educational contexts in pedagogical institutions.

Benjamin Frentsos is a 4-H and Youth Development Extension Agent at Montana State University Extension (Montana State University, Bozeman, Montana, USA) and Global Fellow working to increase access to Positive Youth Development in Romania.

\section{References}

Bocoș, M., \& Jucan, D. (2019). Fundamentele pedagogiei. Teoria şi metodologia curriculumului. Repere şi instrumente didactice pentru formarea profesorilor. Ediția a IV-a. Pitești: Editura Paralela 45.

Bocoş, M.-D. (coord.), Răduț-Taciu, R., \& Stan, C. (2017). Dicționar praxiologic de pedagogie. Volumul III (I-L). Pitești: Editura Paralela 45.

Kolb, D. (1984). Experiential learning, Englewood Cliffs, N.J.: Prentice Hall.
Kolb, D. (2015). Experiential Learning. Experience as the Source of Learning and Development, New Jersey: Pearson Education.

Curriculum relevant, educație deschisă pentru toți CRED, Cod SMIS 2014+: 118327, proiect cofinanțat din Fondul Social European prin Programul Operațional Capital Uman 2014-2020. Available at: https://formare.educred.ro/course/view.php?id=1139 (accessed at 23.09.2020).

Ministerul Educaţiei Naţionale, Consiliul Naţional Pentru Curriculum (1998). Programe școlare pentru invățământul primar. București: Editura Corint.

Ministerul Educației Naţionale. (2013). Curriculum Național- Programe şcolare in vigoare Available at: http://programe.ise.ro/Portals/1/2013_CP_I_II/01_CL R_CP_II_OMEN.pdf http://programe.ise.ro (accessed at 03.09.2020).

Recommendation of the European Parliament and of the Council of 18 December 2006 on key competences for lifelong learning (2006/962/EC) disponibil on-line la adresa: $\quad$ https://eur-lex.europa.eu/legalcontent/RO/TXT/?uri=celex:32006H0962 (accesed la 24.09.2020). 


\section{Strategies to Improve Children's Interest in Reading Activities}

Diana-Crina Marin, Mușata Bocoș 


\title{
Strategies to Improve Children's Interest in Reading Activities
}

\author{
Diana-Crina Marin ${ }^{a}$, Mușata Bocoș ${ }^{b}$ \\ a Doctoral School "Education, Reflection, Development”, Babes-Bolyai University Cluj-Napoca, 7 Sindicatelor Street, 400029, Romania \\ ${ }^{b}$ Babes-Bolyai University, Faculty of Psychology and Educational Sciences, 7 Sindicatelor Street, 400029, Cluj-Napoca, Romania
}

*Corresponding author: crinadiana88@yahoo.com

\section{Abstract}

\section{Keywords:}

Reading habits; primary school; educational partnership; efficient strategies; interactive learning.
Through this study, we aimed to establish which are the main strategies that teachers use to increase pupils' interest in reading activities. It is unanimously accepted that frequent reading of texts has a beneficial effect on the harmonious development of each pupil. In order to create an inventory of examples of good practices provided by teachers for primary education, an online questionnaire was administered between June and October 2020. 219 teachers have completed the questionnaire and mentioned which strategies they use most frequently to make pupils appreciate the value of the books and to read more frequently. The study revealed several good practices that can be used by teachers or parents to motivate pupils to be more actively engaged in reading activities. These results are useful for primary school teachers who can use them to improve the strategies they use to determine pupils to read more frequently and with pleasure. Working with the books, frequent presentation of the content of some books, organizing reading clubs, visiting the school library, arranging a reading corner, and making portfolios about the content of favorite books are some of the strategies mentioned by teachers.

\section{Zusammenfasung}

\section{Schlüsselworte:}

Lektüreangewohnheit; Grundschule;

Ausbildungspartnerschaft; wirksame Strategien; interaktives Lernen.
Durch diese Studie nahmen wir uns vor, die wichtigsten Strategien zu identifizieren, welche die Lehrer für den Primärunterricht benutzen, damit die Schüler sich für die Lektüre mehr interessieren. Man geht einstimmig davon aus, dass das regelmässige Lesen bestimmter Texte sich günstig auf die harmonische Entwicklung der Kleinen auswirkt. Um die Beispiele bezüglich der guten Vorgänge der Lehrer vom Primärunterricht hervorzuheben, wurde ein Online-Fragebogen im Zeitraum Juni-Oktober 2020 benutzt. 219 Lehrer füllten diesen Online- Fragebogen aus und erwähnten, welche Strategien sie am meisten benutzen, damit die Schüler die Bücher schätzen und häufig lesen. Die Studie zeigte eine Reihe von Gebräuchen, die von den Lehrern oder von den Eltern benutzt werden können, damit die Schüler die Lektüre lieben. Diese Ergebnisse sind den Lehrern für den Primärunterricht nützlich und man kann sie verwerten, um die von ihnen benutzten Strategien, damit die Schüler häufiger und gern lesen, zu verbessern. Die Arbeit mit dem Buch, die häufige Darstellung des Inhalts bestimmter Bücher, die Veranstaltung der Lektüreclubs, die Besichtigung der Schulbibliothek, die Einrichtung eines Lektüreraums und die Erstellung eines Portfolios über den Inhalt der Lieblingsbücher zählen zu den Strategien, die am meisten von den Lehrern benutzt werden.

\section{Introduction}

Frequent reading of age-appropriate books contributes significantly to optimizing the school results of the pupils. Most of the pupils allocate very little time to do reading activities. Starting from the premise that if we use effective strategies that were recommended by a large number of teachers, will increase pupils' interest in reading, we have conducted a study that aimed to collect information on how teachers determine pupils to read. The benefits of frequent book reading are unanimously accepted. Frequent use of new technologies and the high quantity of time allocated to use electronic devices with the visual display are factors that can influence in a negative way the pupils' level of interest in reading. The main challenge encountered in developing pupils' interest in reading activities is related to the absence of desire to read books, even if the books are appropriate to their age.

\section{Theoretical foundation}

The reading abilities of the children and their interest in reading are developed during the primary school cycle. Strategies used in the classroom by the teacher can influence the well-being of pupils and their decisions regarding the learning processes or reading habits (Chu, $\mathrm{Li} \& \mathrm{Yu}, 2020$ ). Teachers make systematic efforts to develop pupils' interest in reading. Visits to libraries are some of the most frequently used strategies to familiarize children with reading (Gong, 2016). Some researchers have shown that pupils will enjoy reading if they do these activities in the company of colleagues, family members, and even in the 
presence of pets. Developing correct reading and writing skills is an extremely complex process (Johnston \& Watson, 1997). Pupils' performance in reading processes, during first grade, can be an important predictor of pupils' interest in reading activities, but other factors can influence significantly the motivation of the pupils to perform such activities (Kirby, Ball, Geier, Parrila \& Wade-Woolley, 2010). Identifying optimal strategies to stimulate and sustain pupils' interest in reading activities has beneficial effects and is not always a simple process (Mathison, 1989). Also, some pupils read frequently, while others read less often.

Understanding the reading habits of the children and their attitudes has a positive impact on teachers' work. Gender differences and the reading habits of family members are factors that can influence children's interest in reading (Mostert \& Wikan, G, 2008, Rasinski, 1991; Uusen, \& Müürsepp, 2012). Digital resources can be also used to increase pupils' interest in reading activities (Narulita Mahendra, 2020). Books in electronic format are considered attractive by some of the pupils. Stimulating children's interest in reading activities should start at an early age. Also, children's interest in reading is closely related to the positive parenting practices adopted by parents. (Pezoa, Mendive \& Strasser, 2019). Knowing a large variety of examples of good practices that were applied in classroom activities or during programs organized with the purpose to stimulate children's interest in reading can help us to improve our teaching strategies (Sánchez, Campillo \& Díaz, 2020). Activities such as writing, cooperative learning, or frequent reading have a positive impact on pupils' creative thinking (Segundo Marcos, López Fernández, Daza González \& Phillips-Silver, 2020). Reading aloud by parents each day has beneficial effects on children's development (Zivan \& Horowitz-Kraus, 2020).

\section{Research methodology}

To conduct this research, an online questionnaire was created. The questionnaire was distributed in the online environment and was completed by 219 teachers. The content of the questionnaire is included in Annex A. Through this study, we aimed to find the answer to the following questions:

- How often are pupils involved in reading activities?

- What can teachers and parents do to increase pupils' interest in reading activities?

\section{Results}

Most of the teachers who have decided to fill in the questionnaire work with pupils enrolled in the third grade (54 respondents). Also, a large number of respondents work with children from the first grade or the second grade (see figure 1).

Figure 1. The description of the sample of the respondents

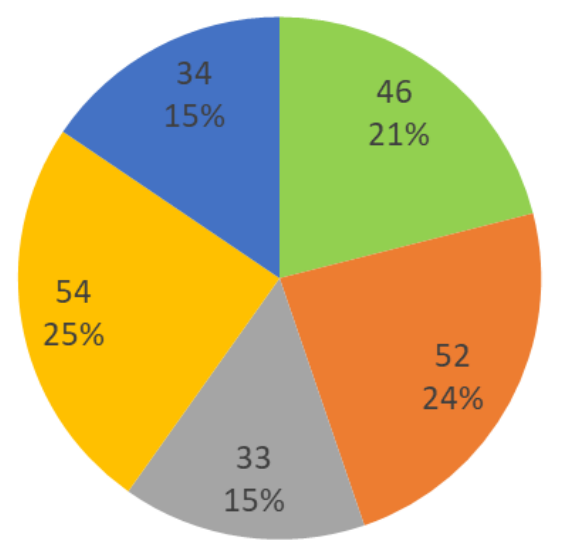

- Preparatory grade $\square$ 1st grade $\square$ 2nd grade $\square$ 3rd grade $\quad$ 4th grade

Most teachers appreciated the fact that the school library contains age-appropriate books for primary school students. 119 of them selected the affirmative answer to the second question of the questionnaire: "Do you think that the school library has enough books for primary school pupils?". A part of the respondents considered that the school library is not well equipped with new books. Some of the respondents showed that there is no library inside the school (see figure 2).

Figure 2. Teachers' opinion regarding the quantity of the books included in the school library

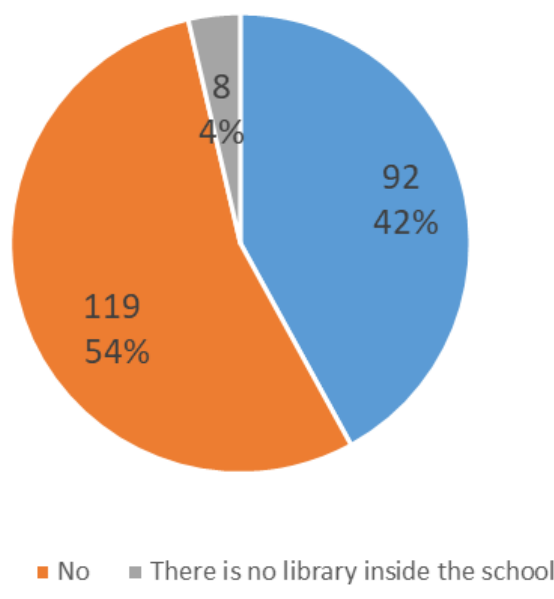

Most teachers appreciated the fact that the school library contains age-appropriate books (see figure 3) and offered a positive answer for the question: "Do you think that the books from the school library are suitable for the reading interests of your pupils?" (see figure 3 ). Teachers who chose "Another answer" mentioned that 
the library contains old or very old books and the fact that the books that appeared recently in the field of children's literature are not enough. Some teachers mentioned that they have decided to create a classroom library because there is no library inside the school.

Figure 3 . The characteristics of the books included in the school library

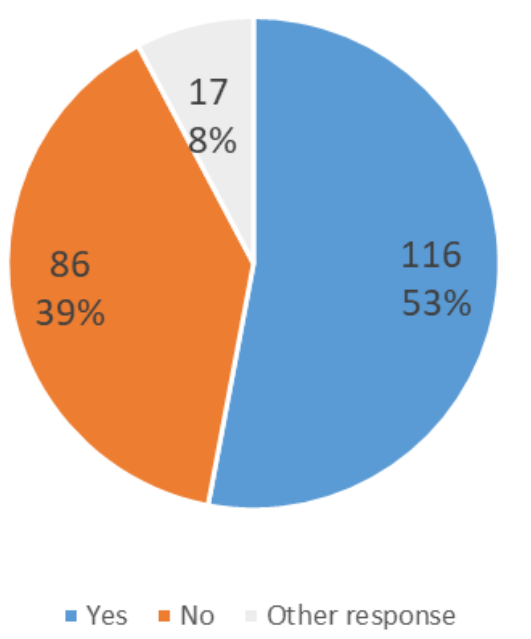

Most of the teachers appreciate that their pupils always read often or very often ( $41 \%$ of them). However, the same percentage showed that their pupils read rarely ( $41 \%$ of them). $10 \%$ of them read always, while 17 of them have selected another response variant (see figure 4 and figure 5).

Figure 4 . Frequency of the reading activities

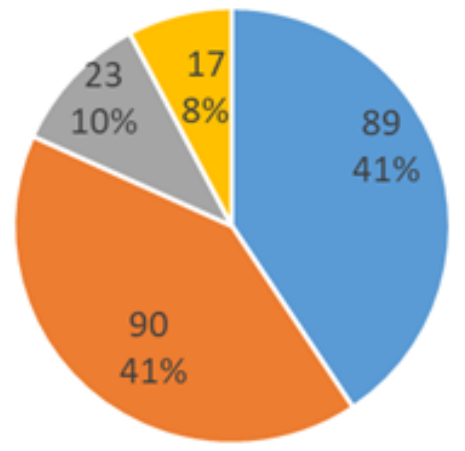

" Rarely " Often or very often " Always "Other response

Figure 5. Frequency of the reading activities. Comparative results.

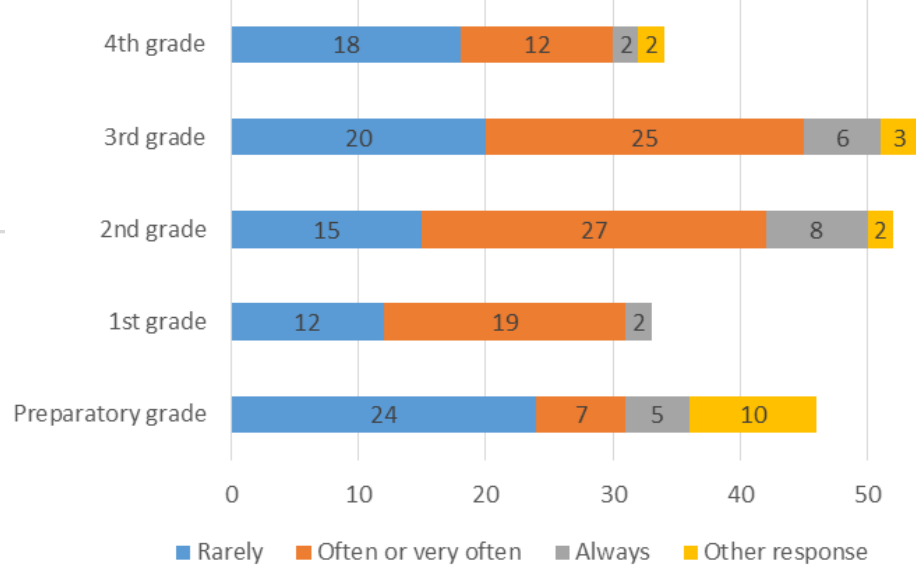

The teachers who have selected another response variant mentioned the fact that some pupils did not read with pleasure. They decide to read if the teacher asks them to carry out such activities or if the reading activities are organized in the school space. Teachers mentioned that they use various strategies to determine pupils to read. For example, they decide to choose a book that should be read in a certain amount of time by all the pupils from the class or organize a reading club in the school space or in the online environment. Most often, pupils read books that were recommended by teachers. They also mentioned that some pupils read more often, while others read rarely or extremely rarely. The reading skills of a part of the pupils enrolled in the preparatory grade were not sufficiently developed at that moment, but they carry reading activities with their parents or enjoy browsing through books.

At question number 5, "What strategies did you use to get your pupils to spend more time reading?", teachers provided answers such as those included in the table below (see table 1).

Table 1. Strategies recommended by teachers

\begin{tabular}{|c|c|c|c|c|c|}
\hline Recommended strategies & 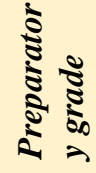 & 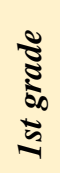 & 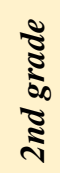 & 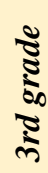 & 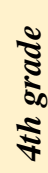 \\
\hline $\begin{array}{l}\text { - presentation of some books in } \\
\text { which the characters are close to } \\
\text { the pupils' age; }\end{array}$ & & & & $\sqrt{ }$ & \\
\hline $\begin{array}{l}\text { - studying an optional subject in } \\
\text { which reading activities are } \\
\text { encouraged; }\end{array}$ & & & & $\sqrt{ }$ & \\
\hline - organizing a reading club; & $\checkmark$ & $\sqrt{ }$ & $\checkmark$ & $\sqrt{ }$ & $\checkmark$ \\
\hline $\begin{array}{l}\text { - arranging a mini-library / reading } \\
\text { corner in the classroom; }\end{array}$ & $\checkmark$ & $\checkmark$ & $\checkmark$ & $\sqrt{ }$ & $\checkmark$ \\
\hline $\begin{array}{l}\text { - organizing competitions such as } \\
\text { "Recognize the character", }\end{array}$ & $\checkmark$ & $\checkmark$ & & & \\
\hline
\end{tabular}


"Recognize the story", "Read quickly and well";

- organization of competitions, such as "Present the book",

"Reading chain", "Reading tree",

"The most active reader of the class", "Information about authors and books";

- role-reading activities;

- making panels in the classroom with information about pupils' reading preferences (eg, "Our Favorite Books," "Reading Chest," etc.);

- making portfolios entitled: "My favorite books", "Reading of the month", "The way of the book", etc .;

- awarding prizes or rewards, such as books, grades, diplomas, verbal assessments, badges with the text

"Best Reader", etc.);

- dramatization of some of the

stories preferred by pupils;

- creating contexts to present

interesting books;

- organize daily reading activities;

- stimulating pupils' curiosity to

find out the continuation or end of

a text by presenting its beginning

in an attractive way (using the

prediction method);

- creating active partnerships with

the school and the local library;

- visiting memorial houses;

- filling in reading sheets;

- watching sequences from the film

with the purpose to arouse interest

in the content of the book;

- organizing educational games

with the purpose to promote

reading activities;

- conducting role-playing games;

- organizing carnival-type

activities, in which pupils dress up

as various characters from their

favorite books;

- retelling some texts (with the

help of some suggestive images);

- watching or listening to stories;

- choosing some books that should

be read in the next period, with the

help of pupils;

- organizing visits/workshops to

bookstores;

- reading texts with guests or

family members in the school

space;
- using digital devices or

applications to improve children's

ability to read;

- making costumes worn by

characters from stories;

- discussions by which the content

of a book is compared with the

content of the movie realized based on the book;

- creating contexts through which

pupils can present to their

classmates the content of the books

they read;

- organizing literary sessions;

- organizing meetings with writers;

- creating reading journals;

- participation in book fairs;

- conducting book reviews;

- carrying out reading activities

every evening, with the help of

distance communication platforms

(A possible title for these activities could be: "A new evening, another reader").

Teachers who teach at preparatory grade have mentioned that they use books with attractive illustrations and surprising events. They also recommended frequent use of images, and drawings, showing PPT presentations, or watching videos. Primary school teachers have shown that they frequently read riddles to pupils and try to organize active learning situations. Teachers mentioned that pupils like to solve puzzles with characters or scenes from stories.

During the first grade, some teachers mentioned that they change the length and size of the texts in order to make them more accessible to pupils. Teachers also use comics. Also, parents are encouraged to read aloud for their child at least one page a day. The pupils' library must also contain age-appropriate books. Attractive books, interesting titles, and brightly colored illustrations should be included in the class library. Books that can be read by pupils are also presented to parents and children with the purpose to choose relevant titles for reading activities.

During the second, third, or fourth grade, the teachers recommend the realization of reading journals and the creation of portfolios related to the content of the books that were already read. Such portfolios could include the products of pupils' activities such as identifying beautiful expressions, making the reading map, transcribing the favorite passage, and drawing a character. Also, the usefulness of reading activities is 
outlined during the school lessons. Teachers mentioned that it is not easy to increase the pupils' interest in reading books. The personal example offered by the parents and the teachers could be important factors that influence pupils' desire to read books more frequently. Some teachers recommend age-appropriate books to pupils and give pupils a high degree of freedom in choosing the books they read. Other teachers mentioned that reading activities are mandatory for all pupils and outlined that they set the title of a book that should be read during a preset interval of time.

In the second grade, most teachers mentioned that their pupils participate each month in the reading club activities. Some teachers organize such activities more frequently, once every two weeks or even weekly. During these activities, aspects related to the books that were read by the pupils are discussed in a relaxing atmosphere. The activities of the reading club can be done outdoors when the weather is favorable. Teachers and pupils decide to participate frequently in cultural activities, such as puppet theater. Books from different fields could be used to make interdisciplinary connections. Reading aloud activities for their parents or other family members can be carried out at home.

Teachers who teach in the third grade mentioned that watching or listening to movies will be done after reading the whole text. New books are presented weekly or monthly. Teachers often recommend books from their library, starting from the premise that through the power of personal example they will be able to stimulate pupils' interest in reading texts. Organizing contexts in which pupils and parents can carry out together reading activities in the school space have beneficial effects. Thus, both parents and teachers will provide models of positive behavior for pupils. Some teachers mentioned that they often lend books from their library to pupils. Teachers considered that the involvement in campaigns/projects carried out at local or national level through which reading activities are promoted has positive effects on improving the reading habits of their pupils.

Organizing Bingo games or creating book reviews were some of the activities that were recommended by teachers who teach in the fourth grade. In various school contexts, books are recommended with the purpose to find out more information about the topics taught by the teacher. Teachers mentioned that pupils can be involved as volunteers in projects that promote reading. Some of the teachers outlined that they use to give homework that can be solved only by reading some information included in the books from the pupil's library.

The study participants advised pupils to read various books, written by Romanian authors or by writers from other countries. Authors that were most frequently recommended were: Ion Creangă, Gelu Naum, Alec Blenche, Roald Dahl, Hans Christian Andersen, Brothers Grimm, and James Orchard Halliwell-Phillipps.

\section{Discussions}

The strategies that should be applied in the family environment should be established during the teacherparent conferences, in order to increase pupils' interest in reading. Involving pupils in arranging their own library or the classroom library will stimulate their curiosity and motivation to initiate reading activities. Collaborative learning activities could be used to stimulate pupils' interest in reading books. During this type of activities should be used interesting and attractive books. Teachers can also present books from their library during school activities and talk about the content of the books that they enjoyed. Managers of each educational institution should make efforts to properly equip the school library.

\section{Conclusions}

The study revealed that primary school teachers are using a large diversity of strategies to encourage pupils to read more frequently. They make considerable and systematic efforts to include reading activities in pupils' daily schedule. The libraries from Romanian schools should be more efficiently equipped to provide pupils with the best educational opportunities.

\section{Acknowledgments}

We would like to thank all the participants for their support in conducting this study.

\section{Appendix A.}




\section{Questionnaire addressed to primary school teachers}

Dear colleagues,

Based on your teaching experience, please complete this online questionnaire. We intend to make an inventory of some reading materials, which could be recommended to primary school pupils.

1. 1. In which class do you teach?

$\ulcorner$ Preparatory grade

$\Gamma 1^{\text {st }}$ grade

$\Gamma 2^{\text {nd }}$ grade

$\left\lceil 3^{\text {rd }}\right.$ grade

$\Gamma 4^{\text {th }}$ grade

2. Do you think that the school library has enough books for primary school pupils?

$\Gamma$ Yes

$\Gamma$ No

$\ulcorner$ There is no library inside the school

3. Do you think that the books from the school library are suitable for the reading interests of your pupils?

$\Gamma$ Yes

$\Gamma$ No

$\ulcorner$ Other response

4. Most children from your class are reading:

$\ulcorner$ Rarely

$\Gamma$ Often or very often

$\Gamma$ Always

$\ulcorner$ Other response

5. What strategies did you use to determine your pupils to read more?

6. Mention one or more books that you have recommended to your pupils. Choose books that you consider valuable, age-appropriate, and attractive for your pupils.

Authors note: The authors had equal contributions to this article.

Diana-Crina Marin is currently a teacher at „Pavel Dan” Theoretical High School, in Câmpia Turzii and postdoctoral researcher at the Babeș-Bolyai University. Her research areas are aimed to find innovative modalities to consolidate the school-family partnership, considering that the school and family should be real partners regarding the children's education. She is also interested in finding the most effective teaching practices that could be successfully used in the educational process.

Mușata Bocoș is a University Professor and Ph.D. Coordinator at the Faculty of Psychology and Sciences of Education (Babeș-Bolyai University, Cluj-Napoca,
Romania). In 1997, she obtained a Ph.D. in Educational Sciences, at the Babeș-Bolyai University. Her research interests are reflected in a series of studies and articles published in important national and international journals. Her teaching activity covers several areas, such as the curriculum theory and methodology, general didactics, and educational research.

\section{References}

Chu, L., Li, P.-H., \& Yu, M.-N. (2020). The longitudinal effect of children's self-regulated learning on reading habits and well-being. International Journal of 
Educational Research, 104, 101673. Available at: https://doi.org/10.1016/j.ijer.2020.101673 (accessed at 08.01.2021).

Gong, X. (2016). Efforts to Develop the Reading Interest of the People from Children in Singapore Libraries. Science Journal of Education, 4(6), 198-205. Available at: $\quad$ https://doi.org/10.11648/j.sjedu.20160406.16 (accessed at 17.12.2020).

Henderson, L., Grové, C., Lee, F., Trainer, L., Schena, H., $\&$ Prentice, M. (2020). An evaluation of a dog-assisted reading program to support student wellbeing in primary school. Children and Youth Services Review, 118, 105449.

Available

https://doi.org/10.1016/j.childyouth.2020.105449 (accessed at 17.12.2020).

Johnston, R. S., \& Watson, J. (1997). Developing Reading, Spelling and Phonemic Awareness Skills in Primary School Children. Reading, 31(2), 38-41. Available at: https://doi.org/10.1111/1467-9345.00052 (accessed at 03.02.2021).

Kirby, J. R., Ball, A., Geier, B. K., Parrila, R., \& WadeWoolley, L. (2010). The development of reading interest and its relation to reading ability. Journal of Research in Reading, 34(3), 263-280. Available at: https://doi.org/10.1111/j.1467-9817.2010.01439.x (accessed at 03.02.2021).

Mathison, C. (1989). Stimulating and sustaining student interest in content area reading. Reading Research and Instruction, 28(3), 76-83. Available at: https://doi.org/10.1080/19388078909557977 (accessed at 08.01.2021).

Mostert, L., \& Wikan, G. (2008). Reading habits and attitudes of primary school pupils in Namibia and Norway. Education as Change, 12(1), 95-107. Available at: https://doi.org/10.1080/16823200809487197 (accessed at 08.01.2021).

Narulita Mahendra, F. F. (2020). Mobile Assisted
Language Learning: Increasing Students' Reading Interest trough E-book. Acitya Journal of Teaching \& Education, 2(1), 1-11. Available at: https://doi.org/10.30650/ajte.v2i1.272 (accessed at 08.01.2021).

Pezoa, J. P., Mendive, S., \& Strasser, K. (2019). Reading interest and family literacy practices from prekindergarten to kindergarten: Contributions from a cross-lagged analysis. Early Childhood Research Quarterly, 47, 284-295. Available at: https://doi.org/10.1016/j.ecresq.2018.12.014 (accessed at 28.01.2021).

Sánchez, M., Campillo, M., \& Díaz, M. P. (2020). Reading mentors in primary education. Lessons learned from piloting an intergenerational school model. International Journal of Educational Research, 100, 101539. Available at: https://doi.org/10.1016/j.ijer.2020.101539 (accessed at 30.01.2021).

Segundo Marcos, R. I., López Fernández, V., Daza González, M. T., \& Phillips-Silver, J. (2020). Promoting children's creative thinking through reading and writing in a cooperative learning classroom. Thinking Skills and Creativity, 36, 100663. Available at: https://doi.org/10.1016/j.tsc.2020.100663 (accessed at 30.01.2021).

Uusen, A., \& Müürsepp, M. (2012). Gender Differences in Reading Habits Among Boys and Girls of Basic School in Estonia. Procedia - Social and Behavioral Sciences, 69, 1795-1804. Available at: https://doi.org/10.1016/j.sbspro.2012.12.129 (accessed at 07.02.2021).

Zivan, M., \& Horowitz-Kraus, T. (2020). Parent-child joint reading is related to an increased fixation time on print during storytelling among preschool children. Brain and Cognition, 143, 105596. Available at: https://doi.org/10.1016/j.bandc.2020.105596 (accessed at 07.02.2021). 


\section{Use of Multisensory Room in the Development of} Psychomotricity in students with Autism Spectrum Disorder and Intellectual Disability

Silvia Alexandrina Jucan, Cristian Stan, Cornelia Stan 


\title{
Use of Multisensory Room in the Development of Psychomotricity in students with Autism Spectrum Disorder and Intellectual Disability
}

\author{
Silvia Alexandrina Jucan ${ }^{\mathrm{a}}$, Cristian Stan ${ }^{\mathrm{b}}$, Cornelia Stan ${ }^{\mathrm{c}}$ \\ a Doctoral School "Education, Reflection, Development”, Babes-Bolyai University Cluj-Napoca, 7 Sindicatelor Street, 400029, Romania \\ ${ }^{b, c}$ Babes-Bolyai University, Faculty of Psychology and Educational Sciences, 7 Sindicatelor Street, 400029, Cluj-Napoca, Romania
}

*Corresponding author: silvialexandrina.chis@yahoo.com

\section{Abstract}

\section{Keywords:}

Autism Spectrum Disorder; Psychomotricity; Intellectual Disability; Special-Needs Education; Intervention Plan.

The schooling of children with autism spectrum disorder (ASD) and severe intellectual disability (ID) in special schools, requires personalized professional intervention. Sensory, motor and psychomotor education of the disabled child is an important part of integration in all aspects: educationally, professionally, socially. Activities aimed for the development of the psychomotricity in children with ASD and severe ID are carried out in accordance with the requirements of the national curriculum for special-needs education. The multisensory room is a complex of multifaceted instrument.

Our study aims to establish the level of efficacy of an intervention program comprising of activities for the development of psychomotricity carried out in the multisensory room, individualized for children with ASD and severe ID.

\section{Zusammenfasung}

\section{Schlüsselworte:}

Autismus-Spektrum-Störung; Psychomotorik; beschränkter Intellekt; Sonderpädagogik; Interventionsplan.

Die Schulbildung von Kindern mit schwerer geistiger Behinderung (GB) und Autismus-SpektrumStörung (ASS) in der Sonderschule beinhaltet angepasste spezialisierte Intervention. Die sensorische, motorische und psychomotorische Bildung des Kindes mit Behinderung ist ein wichtiger Bestandteil der Integration in allen Aspekten, sowohl in pädagogischer, beruflicher als auch in sozialer Hinsicht. Die Aktivitäten zur Entwicklung psychomotorischer Fähigkeiten bei Kindern mit ASS und schwerer GB werden in Bezug auf den Lehrplan für Sonderpädagogik durchgeführt. Der multisensoriche Raum ist ein Komplex von Instrumenten mit mehreren Valenzen.

Unsere Studie zielt darauf ab, den Wirkungsgrad eines Interventionsprogramms zu ermitteln, das Aktivitäten zur Entwicklung psychomotorischer Fähigkeiten umfasst, die im multisensorischen Raum durchgeführt werden und für Kinder mit ASS und schwerer GB idividualisiert sind.

\section{Introduction}

We refer to psychomotricity as an expression of a personal GPS, a tool used by a child to learn how to place himself in space and in time, to adapt to the changing educational and social environment. Starting from the premise that the main activities in children's development are play, environmental exploration, and psychomotricity, our research has also valued these components in the children in our target group. Children with ASD and ID have difficulties in motor coordination and spatial orientation, throughout the determining factors: perception, orientation, etc. These psychomotor difficulties require specialized interventions from the first observation of their occurrence, as well as the evaluation of the development of the psychomotor components. The detection of psychomotricity disorders and early intervention on psychomotor development help in training the necessary skills vital in school activity and then for the social and professional integration of the disabled child.

Due to its importance in the interpersonal relationship development and in the acquisition of physical independence, psychomotricity is an issue of general interest for people with ASD and ID. Psychomotricity is a significant part in educating children with ASD and ID because it helps them build better relationship with others, with the environment around them, to cope with the educational requirements and thus promote personal well-being.

In the context of children's development with the purpose of their integration, specific activities are carried out in the C.R.D.E.I.I. Special-Needs Middle School, activities aimed at educating the psychomotricity of children with ASD, severe ID and associated disabilities. These activities are carried out 
within the sensory, motor and psychomotor education classes. The multisensory room can be a valuable tool in creating the educational and recovery process.

\section{Theoretical foundation}

The specialists in the field define psychomotricity as the inextricable link between the psychic and the motor skills (Horghidan, 2000, Radu \& Ulici, 2003, Epuran, 2011) with major influences on the educational and socio-professional integration of the individual.

The connection between the psychic and the motor functions can be disturbed by close proximity internal and external factors. There is a common etiology between the ID and the psychomotor disorders. The degree of impairment of the sensory-perceptive development, the representation of motor acts is reflected in the psychomotor development of children with ID. The frequency of psychomotor disorders is higher in children with ID (Radu \& Floșnița, 2011). By affecting the sensitivity of the child's movement, the perception of movement is also affected, and, in this context, psychomotricity.

In addition to cognitive impairments (sensory deficits, intelligence disorders, attention deficits, memory disorders, language disorders) and social interaction disorders, psychomotricity disorders also occur in ASD.

According to DSM 5 (2016) ASD and ID fall into the category of neurodevelopmental disorders. ASD occurs very early in the child's preschool period and affects the entire personality, physical, psychomotor, cognitive, socio-emotional development. ID occurs during the child's development period (until the age of 18) before the school period and is characterized by deficits in general mental abilities (reasoning, problem solving, abstract thinking, school learning, learning from experience). This development impairment causes a deficiency on a social, school and occupational personal level and affects the adaptive function of the individual.

Due to the developmental gaps between children of the same age but with different individual characteristics (data such as disability, severity level, association of multiple disabilities in the same child) it is necessary to individualize the intervention and to develop personalised intervention plans.

An intervention tool with multiple applicability in language, cognition and psychometrics is the multisensory room or Snoezelen room, as it was originally called. Studies carried out by Bera (2008), Fava \& Strauss (2010), Ziegler (2015), Toro (2019) have shown that the recovery programmes in the multisensory chamber for people with developmental disorders, autism spectrum disorders, brain damage, profound intellectual disability, dementia, produces beneficial effects on the human being by reducing aggression/self-aggression behaviors, avoidance, stereotyping, inappropriate behavior, significantly better results in solving tasks involving memory, improving concentration and learning capacity, increasing muscle activity, developing general motor skills and perceptive-motor structures.

\section{Research methodology}

In this research we used the following methods and tools for the initial and final evaluation and the development of the psycho-pedagogical intervention plan for the development of general motor coordination, static and dynamic balance, oculomotor coordination in children with ASD and ID

- observation, case study, analysis of the curriculum documents;

Assessment tools:

- Portage Assessment Scale is an inventory of behaviours and abilities that allows an evaluation of the development of children aged 0-6 years and children with disabilities in the following areas: socialization, language, personal autonomy, cognitive skills, motor skills, comprising agebased items that naturally occur in the standard development of a child;

- Callier-Azussa-G Scale is a development scale specifically designed to help assess deafblind children and those with multiple, severe and profound disabilities. Its aim is to provide the necessary information to be able to select the activities appropriate to the level of child development;

- Grid for the evaluation of psychomotor development in children with autism spectrum disorder adapted in terms of the specificity of items in children with autistic spectrum disorder. The selected evaluation grid comprises a set of items that help us identify specific behaviors tracked, an inventory of psychomotor behaviors structured on the components of psychomotricity as on the grid formulated by Radu (2003), which represents an 
inventory of skills of children developed normally in psychomotor aspect aged 3 to 14 years.

Intervention instruments used:

- Multisensory room or Snoezelen room.

- An intervention plan tailored to the needs of each child.

The purpose of this research was to highlight the effectiveness of the activities carried out in the multisensory room related to the psychomotor development of participating children with ASD and severe ID. In the research, through the selected instruments, we monitored the contribution of the psychomotor development of the intervention plan to the psychomotor development of the participants in the program.

Objectives of the research: elaboration and implementation of a psychological-pedagogical intervention plan for the development of general motor coordination, static and dynamic balance, oculomotor coordination in children with ASD and ID, activities carried out in the multisensory chamber within sensory, motor and psychomotor education classes.

\subsection{Target group}

Children participating in the program are enrolled in the 6th grade at the CRDEII Special-Needs Middle School. The number of students in the class is 6, with multiple disabilities. Out of the 6 students enrolled, we selected 3 students in the intervention program, students who responded to the following selection criteria:

\section{- severe deficit in the psychomotor field}

- ASD marker occurrence and ID

Next, we will present the case study representative for the initiated approach, in order to highlight the process taken with the children in the selected sample (three of the six students in the sixth grade). The activities carried out under the intervention plan have as specific objectives: manipulation of objects in the close proximity, training of the general muscles of the hands, torso, neck and legs, formation of the bilateral coordination, walking the routes back and forth with the preservation of balance; the objectives being related proposed research: the development of general motor coordination, static and dynamic balance, oculomotor coordination.

\subsection{Case Study Presentation}

Participant S1, aged 14 years and 1 month at the time of the beginning of the study, attends sixth grade courses at the C.R.D.E.I.I. Special-Needs Middle School. The diagnosis is: autistic spectrum disorder, hyperkinetic syndrome, severe intellectual disability, retardation in language development.

Based on psycho-pedagogical observations we present the main relevant aspects of the pupil S1' $\mathrm{s}$ background information.

$\mathrm{S} 1$ benefited from early intervention. The followed educational route was: special-needs kindergarten, primary school at the special-needs school and, at the time of the start of study, S1 was in the 6th grade in the special needs school. He benefited from specialized intervention in the cognitive, communication/language, personal autonomy, socioemotional, psychomotor fields.

As a main feature of autistic spectrum disorders, he faces difficulties in relationships, disruptive behaviors that negatively influence the educational approach (running away from the classroom to avoid a work load or to attract attention), stereotypes (balance, trotting of the feet with hands held to the chest and while emitting specific sounds), sensory stimulation (visual, tactile). Having fixations on closing and opening doors or on certain objects (glue tubes, cardboard boxes from puzzle games, etc.), the student establishes occasional eye contact and only with the help of verbal and physical prompts, imitation capacity is very low as well as cognitive performance. $\mathrm{S} 1$ exhibits severe language retardation. $\mathrm{S} 1$ has a low ability to concentrate and maintain focus, he concentrates for less than 10 seconds on the workload, often avoids, is not willing to engage in tasks that require sustained physical and mental effort, he often is easily distracted by external stimuli. He shows impulsiveness in his activities and low compliance with tasks. The initiation of social interaction with adults and children is non-existent due to the absence of language.

\section{Results}

The initial assessment intended to provide information about the child's level of development so that, using the data obtained, a personalised intervention plan to be designed. Using these considerations, the following assessment tools were used: Portage Assessment Scale, Callier-Azusa-G Scale, the evaluation grid of psychomotor 
development in children with autism spectrum disorder.

Following the completion of the Portage Assessment Scale for the acquisition of the motor abilities S1 showed a level of development of approx. 2 years and 8 months having acquired a number of 74 behaviors out of 140 items described by the motor skills scale, that is $52.8 \%$ of the total items. Thus, it did not exceed the threshold at 2-3 years, completing $64.7 \%$ of the items for this age range.

After the completion of the Callier - Azusa - G Scale to establish the psychomotor development of the study participant, 4 subscales were completed: postural control, locomotion, development of fine, visualmotor motor skills. All 4 subscales fall into the age group of 24-36 months.

By completing the initial evaluation grid, the following behaviors have been identified as partially acquired : climbing stairs with alternating legs, running on an established path while maintaining balance, having full mobility of the body (rotates the torso, head, limbs), standing on one leg, then on the other with support (5 seconds), having precision in climbing and descending stairs, competence in dressing and undressing himself, walking straight on a line drawn on the floor forward and backward, standing on the tiptoes (a few seconds), standing on one leg, then on the other (3 seconds), from the standing position, with his hands on his hips, bending from the trunk to the front, back, right, left, moving with appropriate balance (on a straight line drawn by the examiner draws (without much precision) a man, a house, a tree), drawing according to the pattern a rectangle, twisting buttons, handles, switches, opening and closes locks, etc., turning the pages of a book (one at a time), folding a paper in half, after demonstration, making balls out of playdoh, performing, after prompting, various hand movements (rises, descents, held up, held sideways)

The student did not perform the following behaviors: descending the stairs with alternating feet, performing long jumps, jumping from one foot to the other, standing on one leg without help (4-8 seconds), walking forwards or backwards on the balance beam (raised from the ground $20 \mathrm{~cm}$ ), jumping over a small obstacle (brick), standing on the tiptoes while executing movements with his hands, scissors cutting, folding a paper square twice diagonally.

Psychomotric intervention
Having as a reference point the information obtained in the initial evaluation, a personalised intervention plan focused on towards the development of psychomotricity aiming mainly the basic motor coordination has been implemented. This consists of the outline of the intervention programme, with the role of developing psychomotricity and more specifically oculomotor coordination, general motor coordination and static and dynamic balance. Its framework has tried to achieve the essential aspects in this respect.

The purpose of the intervention plan was: the development of basic motor behaviours through activities performed in the multisensory chamber.

The specific aimed objectives were: handling objects in close proximity, exercising the main muscles of the hands, torso, neck and feet, training bilateral coordination, walking on a route back and forth while maintaining balance.

Methods used: imitation, modeling, demonstration, explanation, exercise.

Materials used: The following games and devices were used to implement the activities and exercises proposed in the multisensory chamber: the ball pool, magnet fish and fish rod, water bed with resonance system, air bubble column, aroma diffuser, HIFI system with vibrating base, fiber optic system with bright effects, visual effects projector with discs, simple motor route, stones, interactive sensory panel, large fine motor panel, lock box, floor surf, geometric shapes, fruit tower.

The proposed activities were performed in the educational institution during sensory, motor and psychomotor education classes in the multisensory chamber. The activities have been selected in accordance with the pursued objectives.

Proposed activities to achieve the objective: handling objects in close proximity $(\mathrm{O} 1)$ :

- Ball handling exercises in the ball pool (catching/throwing).

- Fish-finding exercises in the ball pool.

- Exercises to use the magnet rod to catch the fish in the ball pool.

- Assembling the motor path. 
Proposed activities to achieve the objective: exercising the main muscles of the hands, torso, neck and legs $(\mathrm{O} 2)$ :

- Climbing exercises using the small stone route.

- Mounting of the motor path consisting of stones and beams. Can be assembled by children and can have varying degrees of difficulty.

- Walking exercises using floor surf.

- Walking a path front-facing.

- Walking exercises using a correct posture.

Proposed activities to achieve the objective: bilateral coordination practice. ( O3):

- Object handling exercises.

- Shapes and colors sorting exercises: geometric shapes.

- Practice Exercises for the fine muscles of the hand and fingers by using large fine motor panel, a lockbox, an interactive sensory panel, wall path with balls.

Proposed activities to achieve the objective: back and forth movement with the preservation of balance. (O4)

- Exercises to maintain dynamic balance by taking a motor balance path walking back and forth.

- Exercises to maintain static balance at the beginning and end of the motor route.

The following devices were used for relaxation: a water bed and resonance system, ball pool, air bubble column, aroma diffuser, HIFI system with vibrating base, fiber optic system with light effects, visual effects projector with discs.

The intervention period was 12 weeks (December 2019-March 2020)

\section{Final assessment}

The final evaluation was carried out at the end of the intervention programme and the following progress was observed in relation to the initial evaluation for the psychomotor field:

After the completion of the Portage scale for the motor area on the basis of his acquisitions $\mathrm{S} 1$ indicated a development level of a child approx. 2 years and 9 months, having acquired a number of 77 behaviors described by the scale items for the motor domain. These behaviors are: turning the pages one by one, making balls out of playdoh, gathering and dismantling stackable toys. Even though S1 has a breakthrough in psychomotor development, he shows serious deficits in general motor skills, orientation in space, and oculo-motor coordination.

On the Callier-Azusa-G Scale the student has acquired new behaviors as follows: on the postural control subscale he is able to stand 3 seconds on one leg; on the locomotion subscale the student walks up and down 4 stairs using alternating legs, he runs and takes the curve; on the scale the development of fine motor skills he is able to use one hand to hold something and with the other to handle another object; on the visual-motor scale he developed the following behaviors: copy a circle, draw horizontal and vertical lines according to a model. S1, even though he had progressed, according to the scale, he did not exceed the 36-month development level threshold, still ranging from 24-36 months.

Reduced aggression and self-aggression were observed due to relaxation and sensory stimulation in the multisensory chamber. Also, after meeting the need for sensory stimulation, the student was more compliant in carrying out tasks.

\section{Discussions}

Final evaluation based on the psychomotor development assessment grid in children with autism spectrum disorder. In this table we will note the behaviours that in the initial phase were in the process of being achieved and those that were not present then but were developed as a result of the intervention. 
Table 1. Psychomotor behaviors in the initial and final stage

\begin{tabular}{|c|c|c|}
\hline Behavior & $\begin{array}{l}\text { Presence/absence of behaviour at the } \\
\text { initial assessment stage }\end{array}$ & $\begin{array}{l}\text { Presence/absence of behaviour at the final } \\
\text { assessment stage }\end{array}$ \\
\hline \multicolumn{3}{|l|}{ General motor coordination } \\
\hline Bending the knees (squats) & Absent & $\begin{array}{l}\text { Bends slowly in the squat position with support } 1 \\
\text { time only when needed (to pick something up), does } \\
\text { not repeat the same action immediately upon request }\end{array}$ \\
\hline Climbing the stairs using alternating legs & $\begin{array}{l}\text { Climbs the stairs one at a time with right foot } \\
\text { forward }\end{array}$ & $\begin{array}{l}\text { Climbs } 4 \text { stairs using alternating legs with hand } \\
\text { support on railing }\end{array}$ \\
\hline $\begin{array}{l}\text { Running on an established path while } \\
\text { maintaining balance }\end{array}$ & Runs on a straight-line path & Passes over 1,2 obstacles, with support \\
\hline $\begin{array}{l}\text { Full mobility of the body (rotates the torso, } \\
\text { head, limbs) }\end{array}$ & $\begin{array}{l}\text { Rotates the head and limbs and partially the } \\
\text { trunk }\end{array}$ & Rotates limbs and torso \\
\hline $\begin{array}{l}\text { Sitting on one leg, then the other with } \\
\text { support ( } 5 \text { seconds) }\end{array}$ & Stands on one leg for 1 second & Stands on one leg 3 seconds with support \\
\hline Precision in climbing and descending stairs & One foot ahead & 4 stairs, alternating legs \\
\hline Independent Dressing & $\begin{array}{l}\text { Pulls his pants but does not properly arrange } \\
\text { them over his belly and buttocks }\end{array}$ & $\begin{array}{l}\text { Correctly arranges pants due to increased torso } \\
\text { mobility } \\
\text { Puts his hands up his sleeves }\end{array}$ \\
\hline \multicolumn{3}{|l|}{ Static and dynamic balance } \\
\hline $\begin{array}{l}\text { Going straight on a line drawn on the floor } \\
\text { back and forth. }\end{array}$ & $\begin{array}{l}\text { Takes } 2 \text { steps forward on a drawn line and } \\
\text { no steps back }\end{array}$ & $\begin{array}{l}\text { Takes } 4 \text { steps forward on a straight line and } 1 \text { step } \\
\text { back }\end{array}$ \\
\hline Standing on tiptoes (a few seconds) & He does not stand on toes & He lifts on toes and descends immediately \\
\hline $\begin{array}{l}\text { Standing on one leg, then on the other ( } 3 \\
\text { seconds) }\end{array}$ & He stands on one leg for 1 second. & Stands on one leg 3 seconds with support \\
\hline $\begin{array}{l}\text { Bowing from the standing position, with } \\
\text { hands on hips, bending the torso to the front, } \\
\text { back, right, left }\end{array}$ & Bends only forward & Bends forward and sideways \\
\hline $\begin{array}{l}\text { Going in balance (on a straight line drawn } \\
\text { by the examiner) }\end{array}$ & Goes in balance 2 steps on a drawn line & Goes in balance 4 steps forward in a straight line \\
\hline \multicolumn{3}{|l|}{ Oculo-motor coordination } \\
\hline $\begin{array}{l}\text { Drawing (without much precision) a man, a } \\
\text { house, a tree }\end{array}$ & $\begin{array}{l}\text { Scribbles with circular movements and } \\
\text { draws lines }\end{array}$ & $\begin{array}{l}\text { Draws a circle (going 2-3 times in a circular } \\
\text { direction) }\end{array}$ \\
\hline $\begin{array}{l}\text { Turning buttons, handles, switches, open } \\
\text { and close locks etc. }\end{array}$ & Twists buttons, handles, switches & Opens and closes locks to open a box \\
\hline Turning pages of a book (one at a time) & Turns multiple pages at once & $\begin{array}{l}\text { The first } 3 \text { pages one by one then loses interest and } \\
\text { turns more at once }\end{array}$ \\
\hline Folding paper in half after demonstration & $\begin{array}{l}\text { Folds a paper in half with physical hand } \\
\text { guidance }\end{array}$ & Folds a paper in half after demonstration \\
\hline Modeling playdoh balls & Model playdoh sticks & Model playdoh balls with a diameter of $1-2 \mathrm{~cm}$ \\
\hline $\begin{array}{l}\text { Performing, by imitation, various hand } \\
\text { movements (lifts, descents, hold-ups, } \\
\text { sideway movements) }\end{array}$ & $\begin{array}{l}\text { Performs, by imitation, various hand } \\
\text { movements (lifts, descents, hold ups, hold } \\
\text { sideways) }\end{array}$ & $\begin{array}{l}\text { Performs, by imitation, various hand movements } \\
\text { (lifts, descents, hold up, hold sideways) }\end{array}$ \\
\hline Unbuttoning buttons & Does not unbutton & $\begin{array}{l}\text { Unbuttons only large buttons with a diameter of } 1.5 \\
\mathrm{~cm}\end{array}$ \\
\hline Closing buttons & Does not finish task & $\begin{array}{l}\text { Able to work with large buttons with a diameter of } \\
1.5 \mathrm{~cm}\end{array}$ \\
\hline
\end{tabular}

There has been made some progress in the psychomotor field, the development of the general motor skills of static and dynamic balance, oculo-

\section{Conclusions}

In the operational approach to education, the implementation of any change requires constant consideration and integration of the following specific aspects: the variables of the change, the ongoing stages of the change, the strategies used to implement the change and the effects of this phenomenon. On the path of change, each of us builds and/or activates certain motor coordination. This improves the quality of life for $\mathrm{S} 1$ and contributes to the well-being of the child.

barriers. A good teacher is mindful of these barriers that need to be overcome without causing malfunctions in teaching and management, or irreconcilable conflicts (Bocoş, Chiş, Răduț-Taciu, 2015).

Improvements in S1's psycho-behaviour were observed as a result of the intervention programme applied. They refer to the development of psychomotricity, namely general motor coordination, 
static and dynamic balance, oculo-motor coordination. During the activities in the multisensory chamber, a decrease in sensory stimulation behaviors (bite of one's own hand, oral stimulation) was observed.

Since significant progress has been made in S1's psycho-behaviour, family involvement is recommended in reference with the intervention plan developed and it needs approval from the parents. The aim is to generalize the skills formed. It is recommended to cooperate with a speech therapy specialist in the particularities of autism, in order to formulate objectives and develop an intervention plan in the area of communication and language (understanding vocabulary, pronunciation of different phonemes, etc.). It is further recommended to stimulate the development of general motor skills, fine hand muscles, oculo-motor coordination to improve the quality of life and the exercise of the selfmanagement skills/personal autonomy (to dress himself, to place clothes in the folded closet, to clean after themselves, to butter a slice of bread, etc.).

The research initiated, with the general objective of developing psychomotricity in students with ASD and ID, by presenting the selected Case Study, aimed to highlight the intervention process on basic motor coordination through activities carried out in the multisensory chamber.

The obtained results recommend interventions in other situations with the prospect of generalizing the followed process, with the required customizations.

Authors note: The authors had equal contributions to this article.

Silvia Alexandrina Jucan is currently a teacher at „C.R.D.E.I.I. Special-Needs Middle School” in ClujNapoca and a PhD Student at Faculty of Psychology and Sciences of Education (Babeș-Bolyai University, Cluj-Napoca, Romania). Her main field of research is psychomotricity and intellectual disability and the influence of both on the children's writing skills.

Cristian Stan is habilitated Professor and Ph.D., Department of Educational Sciences, Faculty of Psychology and Educational Sciences (Babeş-Bolyai University, Cluj-Napoca) and Director of the Doctoral School Education, Reflection, Development. His research area covers several educational domains such as Theory of education, Theory and practice of didactic evaluation, Intercultural education, Didactic communication, etc.
Cornelia Stan Cornelia Stan is a $\mathrm{PhD}$ assistant professor at the Faculty of Psychology and Sciences of Education, at Babeș-Bolyai University Cluj Napoca. Her fields of research and topics of interest are Educational communication, Interculturality, Career counseling, Mentoring and coaching in education.

\section{References}

Bera, D. R. (2008). Multisensory room and specialized dementia programming. Nursing Home Magazyne, 57 (2), 18.

Bocoş, M., Chiș, O., \& Răduț-Taciu, R. (2015). Individual changes and organizational change. Exemplifications for the Romanian preschool teaching system. Procedia - Social and Behavioral Science, 209, 90-95.

Campelo de Lima, A.F., Gehres, A.F., Lorenzini A.R., \& Tenorio Brasileiro, L. (2017). The influence of nonverbal educational and therapeutic Practices in autism spectrum disorder: the possibilities for physical education professionals. Motricidade, Vol. 13, SI, 8796. Available at: http://dx.doi.org/10.6063/motricidade.12867 (accessed at 23.06.2019).

Epuran, M. (1976). Psihologia educației fizice. Bucharest: Sport-Turism Publishing House.

Epuran, M. (2011). Motricitate și psihism în activitățile corporale, Vol. I. Bucharest: Fest Publishing House.

Epuran, M. (2011). Psihologia învăţării motrice - aplicații in activităţile corporale. Bucharest: Discobol Publishing House.

Fava, L., \& Strauss, K. (2010). Multi-sensory rooms: Comparing effects of the Snoezelen and the Stimulus Preference environment on the behavior of adults with profound mental retardation. Research in developmental disabilities. Vol. 31, 160-171. Available at: doi:10.1016/ j.ridd. 2009.08.006 (accessed at 23.06.2020).

Horghidan, V. (2000). Problematica psihomotricității. Bucharest: Globus Publishing House.

Radu, I. D., \& Ulici, Gh. (2003). Evaluarea şi educarea psihomotricităţii copiilor cu dificultăţi psihomotorii de integrare. Bucharest: Humanitas Foundation Publishing House.

Radu, Gh., Floșniță, R. (2011). Specificul procesului instructiv-educativ şi de recuperare în deficiența/handicapul de intelect. In Tratat de psihopedagogie specială, coord. Verza, E.,Verza, F.E., 149-230. Bucharest: University Publishing House.

Toro, B. (2019). Memory and standing balance after multisensory stimulation in a Snoezelen room in people with moderate learning disabilities. British Journal of Learning Disabilities, Vol. 47 (4), 270-278. Available at: https://doi.org/10.1111/bld.12289 (accessed at 23.06.2020).

Ziegler, U. (2015). Multi-Sensory Design as a Health Resource: Customizable, Individualized and StressRegulating Spaces. Massachusetts Institute of 
Technology, Vol. 31 (1), 53-62. Available at: doi: 10.1162/DESI_a_00309 (accessed at 23.06.2020).

DSM-5. (2016). Manual de diagnostic și clasificare statistică a tulburărilor mintale, Ediția a V-a. Bucharest: Callisto Medical Publishing House.

Ordinul nr. 5236/2008 privind aprobarea curriculumului pentru grupele de învățământ special - pedagogie curativă, care integrează elevi/tineri cu deficiențe severe, profunde sau asociate. Available at: http://oldsite.edu.ro/index.php/legaldocs/c1023/.

Programa școlară educație senzorială, motorie și psihomotorie la clasele I-VI. aprobată prin Ordinul Ministrului Educaţiei, Cercetării şi Tineretului nr. 5235/01.09.2008, Available at: http://oldsite.edu.ro/index.php/articles/curriculum/c556 /?startnum=341. 


\section{Criteria for Adapting Students' Practices to Current Conditions}

Luciana Truța, Olga Chiș 


\title{
Criteria for Adapting Students' Practices to Current Conditions
}

\author{
Luciana Truța ${ }^{a^{*}}$, Olga Chiș ${ }^{b}$ \\ a Doctoral School "Educational, Reflection, Development", Faculty of Psychology and Educational Sciences, Babeș-Bolyai University Cluj-Napoca, \\ 7 Sindicatelor Street, 400029, Romania \\ ${ }^{b}$ Babes-Bolyai University, Faculty of Psychology and Educational Sciences, 7 Sindicatelor Street, 400029, Cluj-Napoca, Romania \\ *Corresponding author: lucianatruta1@gmail.com
}

Abstract

Keywords:

Online environement; pedagogical practice; adaptation of educational resources; planning activities; curriculum for preschool education.

\section{Zusammenfasung}

\section{Schlüsselworte:}

Online-Umgebung;

pädagogische Praxis; Anpassung

der Bildungsressourcen;

Planungsaktivitäten; Lehrplan

für die Vorschulerziehung.
The present study aims at identifying some efficient ways regarding the development of the pedagogical practice of students in the Pedagogy of Primary and Preschool Education in a synchronous format. Thus, a series of aspects were identified during the first semester that helped us to highlight the strategies that allow students a good knowledge and understanding of the aspects related to pedagogical practice. The study focused on several components viewed and analyzed from two perspectives: of students with studies in the pedagogical field and of those with studies in another field. Thus, the components followed were: ways of conducting meetings in a synchronous format, methods used, the degree of applicability of the contents, the capacity for reflection and self-reflection on the competencies of the teacher, difficulties and suggestions for improvement. The study's conclusions were based both on the students' answers to the applied questionnaire, but also on the analysis performed by the pedagogical practice tutors, resulting in the fact that the strategies used had an impact on all students and that in the future encouraged autonomy in learning.

\section{Introduction}

The current challenges regarding education are also found in the organization and development of the pedagogical practice of students from the specialization of Primary and Preschool Education Pedagogy, through the need to adapt the entire didactic approach to the conditions in the online environment.

In the operational approach to preschool education, change requires the consideration and integration of the following specific issues: variables of change, ongoing stages of change, strategies used to implement change and the effects of this phenomenon.

"In the path of change, each of us builds and/or activates certain barriers. A dedicated teacher is aware of these barriers to overcome them without causing dysfunctions in the teaching and management process or irreconcilable conflicts. Education can no longer be limited to inducing reactive adaptation, effective for students in a given situation, but to achieve effective proactive adaptability necessary for the existence and development of a changing society." (Bocoș, RăduțTaciu \& Chiş, 2015, p. 90).

\section{Theoretical foundation}

Identifying some guidelines for pedagogical orientation in carrying out educational activities in the online environment remains a challenge. We emphasize here the preoccupation of pedagogues to provide answers for the activities to be effective with some questions regarding the actions of orientation, planning, flexibility, adaptation and application of the contents. 
Utilizing the resources of the new pedagogy existing on the university website, we cut a set of reflexive questions meant to guide the teaching activity in terms of adapting to the conditions of activities in the online environment:

- What are the best ways to achieve my goals?

- How could a combination of asynchronous and synchronous activities support student action?

- What are the activities that are difficult to transfer/adapt for online education? Can they be recreated in virtual space without altering their functions?

- Is it possible to achieve the learning objectives that I set for myself only by carrying out synchronous activities?

- How will I stimulate/succeed the involvement of the students in the course in the conditions of a large group of participants if I opt only for synchronous interaction?

- Will be possible for me to fully deliver courses and seminars asynchronously, without real-time video interactions with students? (source: https:/www.ubbcluj.ro/ro/infoubb/noua_pedagogie_u niversitară/).

Starting from these questions, taking into account the knowledge and skills to be trained in the specialization Pedagogy of Primary and Preschool Education (knowledge of the characteristics of different functions and mental processes in the development of childhood; design and implementation of teaching learning, frontal and individualized, which aims the curricular learning itself, adapted both to the context of the class and to another context, different from the class, teaching methodology, teaching strategies, educational contexts for their application, knowledge of the specifics of school learning, to build challenging learning situations for the student and educational contexts to support this process; evaluation of the effectiveness of educational and training programs; use the modern communication development techniques), recreated the strategy of conducting activities with students, trying to maximize time spent online.

Thus, the activities carried out within the pedagogical practice from the first semester of the academic year 2020-2021 took into account practical aspects specific to early education (curriculum content for early education, specific notions, presentation of the terms used, filmed learning activities, their analysis, examples of activities from all experiential fields, exemplification of how to complete activity observation sheets etc.). Collaborative learning by students during synchronous activities were also encouraged.

\section{Research methodology}

The study was conducted between 02.1027.11.2020, the target group being the students from the specialization Pedagogy of Primary and Preschool Education, the first year at the Faculty of Psychology and Educational Sciences, Babeș-Bolyai University of Cluj-Napoca. It provides feedback on the efficiency of the conduct of pedagogical practice, but also a proposal to improve the conduct.

The objectives pursued in the study were:

- Identifying effective ways and methods of organizing pedagogical practice in the online environment;

- Identifying the degree of applicability of the contents conveyed within synchronous meetings specific to the pedagogical practice;

- The capacity of reflection and self-reflection of the students regarding the difficulties encountered within the pedagogical practice was realized in a synchronous format;

- Identifying the degree of knowledge by students of the competencies specific to a teacher;

- The ability of students to self-evaluate their own competencies compared to those specific to a teacher.

The present study included a number of 47 students from the specialization Pedagogy of Primary and Preschool Education. Of these, $18(38,3 \%)$ have previous studies in the pedagogical field and 29 $(61,7 \%)$ have previous studies in another field, as shown in Figure 1. This aspect is important to see the perspectives of the two categories involved in the study, as well as their perception of the pedagogical practice carried out in the online environment. 
Figure 1. The status of students in terms of previous professional training

Specify your status from the point of view of previous professional training

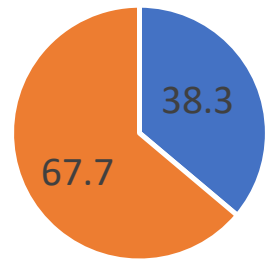

- Studies in pedagogical field (PF)

- Studies in another field (AF)

\section{Results}

Regarding the ways of carrying out the pedagogical practice in the current conditions, we identified the following aspects, highlighted in Figure 2:

Figure 2. Efficient ways of carrying out the pedagogical practice in the current conditions

Wich of the following ways of carrying out the pedagogical practice do you consider effective in the current conditions

38

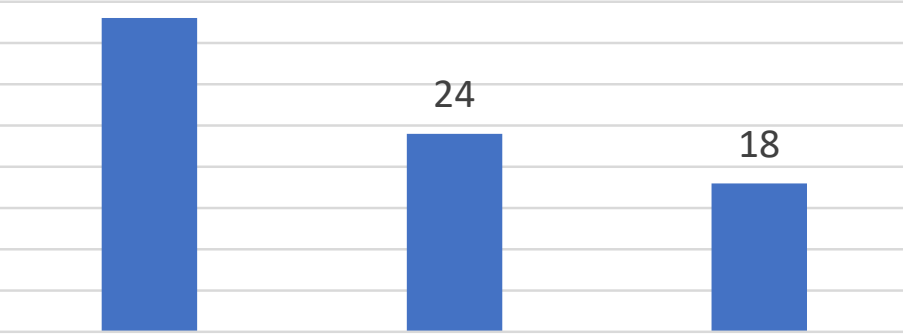

The presentation of

filmed teaching activities and their analysis

$$
\begin{aligned}
& \text { The presentation The presentation of } \\
& \text { theoretical aspects didactic projects and } \\
& \text { specific to the their analysis } \\
& \text { curriculum for early } \\
& \text { education and their } \\
& \text { exemplification }
\end{aligned}
$$

The method most agreed upon by the surveyed students refers to the presentation of filmed teaching activities and their analysis. 38 of the surveyed students chose this method as effective of which 23 were with studies in another field and 15 with studies in the pedagogical field. The next agreed option was to present the theoretical aspects specific to the curriculum for early education and their exemplification (24 students - 19 students with previous studies in another field, 5 students with previous studies in pedagogical field). The presentation of didactic projects and their analysis was the option of 18 students (6 students with previous

studies in another field, 12 students with previous studies in pedagogical field).

Regarding the methods used, the students considered that the discussions based on the topics proposed by the teacher are more effective (33 of the students-19 students with previous studies in another field, 14 students with previous studies in pedagogical field). Discussion based on the topics proposed by students is the second option chosen by them ( 29 of the students-19 students with previous studies in another field, 10 students with previous studies in pedagogical field) and the presentation of some topics made by students is the option of 8 of them (5 students with previous studies in another field, 3 students with previous studies in pedagogical field), according to Figure 3:

Figure 3. Effective methods in carrying out pedagogical practice in synchronous format

Select the methods you consider effective in conducting pedagogical practice in synchronous format (online)

35

30

25

20

15

10

5

0

Discussions based Presentation of Discussion based on topics proposed homework made on topics proposed by students by students 33

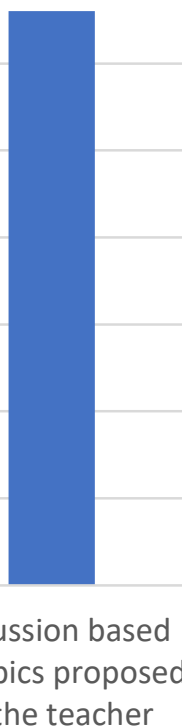


Regarding the degree of applicability of the contents conveyed during the meeting in a synchronous format within pedagogical practice, we found the following:

- Very low: 6\% - 3 students (2 students with previous studies in another field, 1 student with previous studies in pedagogical field)

- Reduced: $20 \%$ - 9 students (6 students with previous studies in another field, 3 students with previous studies in pedagogical field)

- Do not know: 28\% - 13 students (7 students with previous studies in another field, 6 students with previous studies in pedagogical field)

- High: $44 \%$ - 21 students (13 students with previous studies in another field, 8 students with previous studies in pedagogical field)

- Very hight: $2 \%$ - 1 student (1 student with previous studies in pedagogical field)

Figure 4 . The degree of applicability of the contents conveyed within the pedagogical practice

WHAT IS THE DEGREE OF APPLICABILITY OF THE

CONTENTS CONVEYED DURING THE MEETINGS IN SYNCHRONOUS FORMAT WITHIN THE PEDAGOGICAL PRACTICE

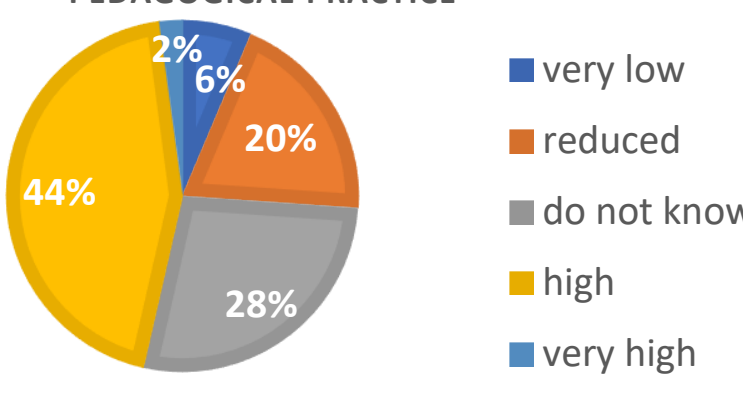

As it appears from the data presented in Figure 4, almost $50 \%$ of the students consider that the degree of applicability of the contents conveyed within the pedagogical practice is high and very high. A worrying aspect refers to the impossibility of almost $30 \%$ of students to decide on how to use/integrate the contents from their personal experience, especially since among them are also students who are based on a training in the pedagogical field. Some correlations will be made later, when the students' perception on their own skills necessary for a teacher approached.

Among the difficulties faced by students, they mentioned issues related to understanding the meaning of specialized terms, time spent on solving tasks, asynchronously, understanding the daily schedule in kindergarten, low concentration in the online environment, how to complete observation sheets (students with previous studies in another field), the impossibility of putting into practice the notions conveyed, direct communication with specialized teachers (students with previous studies in pedagogical field).

Regarding the suggestions about the realization of the pedagogical practice in other ways, students with studies in other fields identified the following: the more in-depth analysis of the curriculum, (4), the realization of some role plays (1), the presentation of several videos with concrete kindergarten activities (2), completing the observation sheets during synchronous meetings (7), 15 of them (52\%) considered that the way to which the pedagogical practice is currently carried out is efficient. Southbased students in the pedagogical field propose the following: more in-depth analysis of the curriculum (3), role-playing games (1), the presentation of several videos with concrete activities in kindergarten (2), the presentation of some activity projects (4), 8 of them (44\%) considering that way to which the pedagogical practice is currently carried out is efficient.

The next aspect addressed in the questionnaire (Figure 5), namely, the identification of the skills needed by the teacher, allows us to identify the degree of knowledge by students of the skills needed by the teacher. Students have developed a hierarchy of these skills as follows:

- Adaptation and use of child-centered teaching and evaluation strategies (methods, teaching aids and form of organization): $89 \%$ - 42 students (27 students with previous studies in another field, 15 students with previous studies in pedagogical field);

- Design and implementation of teachinglearning-assessment activities: 85\% - 40 students (23 students with previous studies in another field, 17 students with previous studies in pedagogical field);

- Documentation, selection, processing. Adaptation of content accessibility: $79 \%$ - 37 students (22 students with previous studies in another field, 15 students with previous studies in pedagogical field);

- Use of effective lifelong learning methods and techniques: $72 \%$ - 34 students (19 students with previous studies in another field, 15 students with previous studies in pedagogical field);

- Self-assessment and continuous improvement 
of professional practices and career development: $70 \%$ - 33 students (19 students with previous studies in another field, 14 students with previous studies in pedagogical field);

- Interpersonal communication in the physical environment: $68 \%$ - 32 students (19 students with previous studies in another field, 13 students with previous studies in pedagogical field);

- Interpersonal communication in the virtual environment: $64 \%$ - 30 students (18 students with previous studies in another field, 12 students with previous studies in pedagogical field);

- Knowledge of the age peculiarities of preschoolers: $60 \%$ - 28 students (13 students with previous studies in another field, 15 students with previous studies in pedagogical field);

- Management of the preschool group: $49 \%-23$ students (10 students with previous studies in another field, 13 students with previous studies in pedagogical field);

- Capitalization in the formal context of acquisitions acquired in nonformal and informal contexts: $45 \%$ - 21 students ( 8 students with previous studies in another field, 13 students with previous studies in pedagogical field);

- Resource management: $40 \%$ - 19 students (8 students with previous studies in another field, 11 students with previous studies in pedagogical field).

Figure 5. Skills needed by a teacher (students' vision)

Identify the competences necessary for a teacher

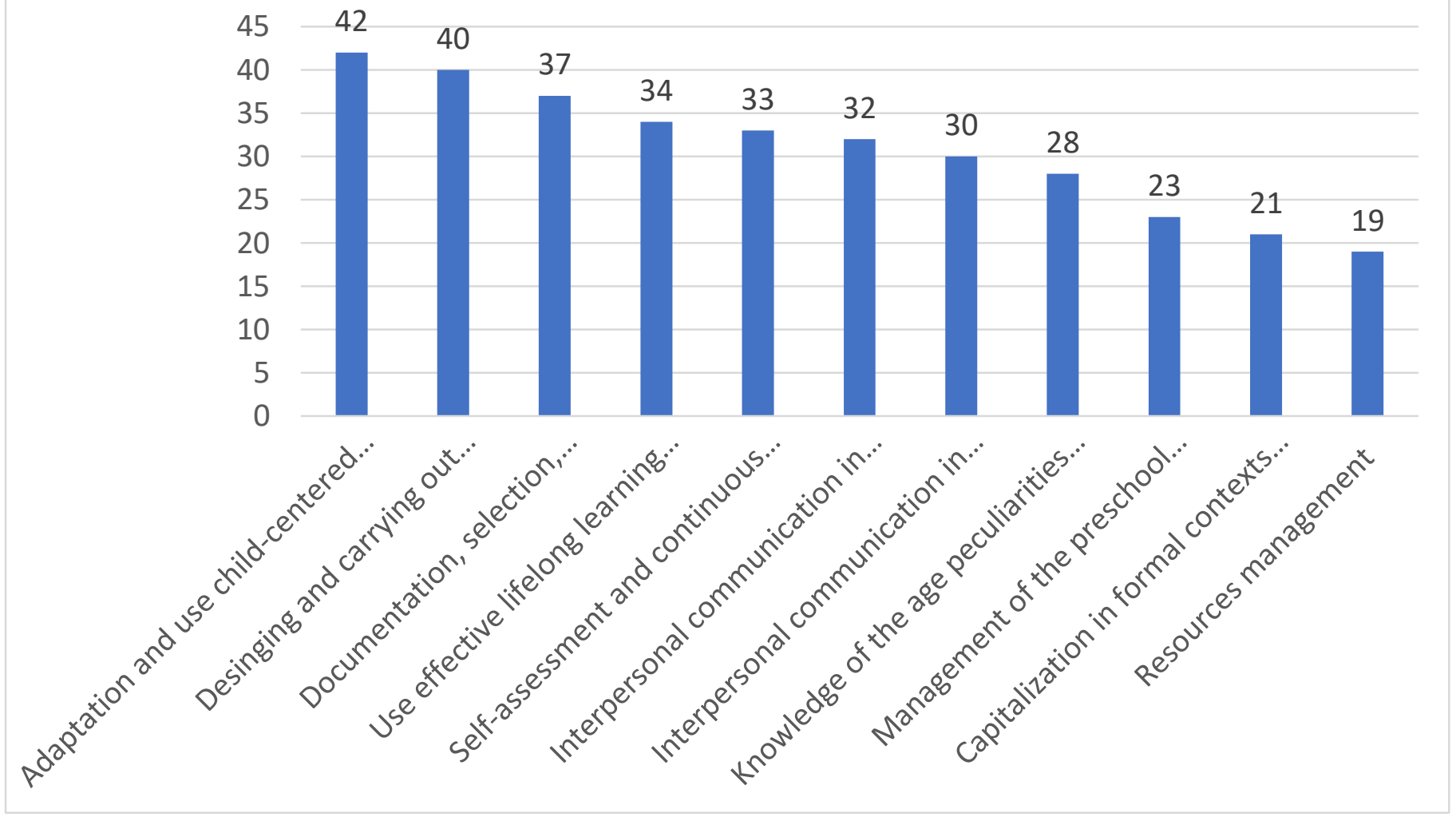

Analyzing the students' answers, we highlight some competencies that students based on pedagogical studies correlate: the adaptation and use of childcentered teaching and assessment strategies (methods, teaching aids and forms of organization) is correlated with the design and implementation of teachinglearning-assessment activities, with knowledge of age peculiarities of preschoolers, with documentation, selection, processing, adapting the accessibility of contents, with the self-evaluation and continuous improvement of the professional practices and with the career evolution (90\% of pedagogical field students). There are also options for using effective lifelong learning methods and techniques and capitalizing in formal contexts on acquisitions acquired in nonformal and informal contexts, which highlights their awareness of lifelong learning that manages "to integrate all three forms of educations: formal, nonformal and informal, allowing the living of real learning experiences in different contexts" (Truța, 2012, p. 7) and the way of organizing and conducting pedagogical practice in the current context allows and 
supports exactly this basic concept of contemporary education.

Analyzing the responses of students based on training in another field, we note that they do not correlate with the skills needed for a teacher, so $93 \%$ of them consider it important to adapt and use childcentered teaching and assessment strategies (methods, means of education and form of organization), but the knowledge of the age peculiarities of preschoolers is considered necessary only by $45 \%$ of them.

Going further and analyzing the answers regarding the necessary competencies of their own educator, students identify the following necessary aspects: adaptation of contents to children, assertive communication, use of diversified strategies, rigorous documentation, applicability of contents, permanent assessment of content comprehension, use of methods effective learning, knowing the needs of children, creating real life situations that allow the application of learned knowledge. These are found in the list of skills of a teacher highlighted by students.

Regarding the self-assessment of the necessary competencies of a teacher for preschool education held by them, we found the following:

Figure 6 . Self-assessment of students on the skills needed by a teacher for preschool education

To what extend do you consider that you have competencies of a teacher for preschool education?

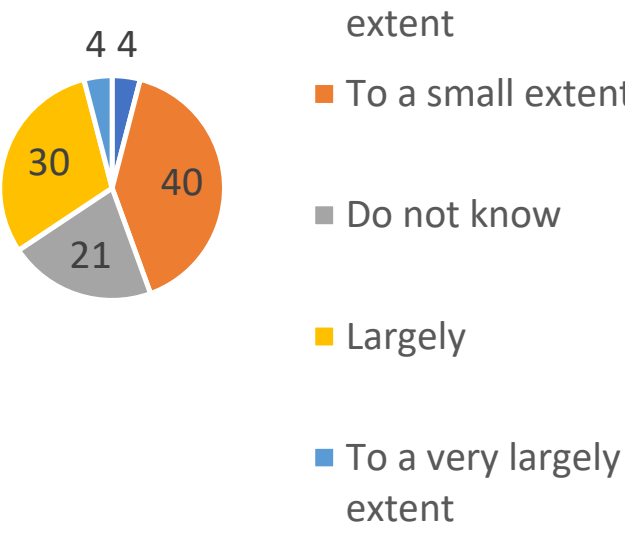

- To a very small extent: $4 \%$ - 2 students with previous studies in another field;

- To a small extent: $40 \%$ - 19 students (9 students with previous studies in another field, 10 students with previous studies in pedagogical field);
- Do not know: 21\% - 10 students (9 students with previous studies in another field, 1 student with previous studies in pedagogical field);

- Largely: 30\% - 14 students (9 students with previous studies in another field, 5 students with previous studies in pedagogical field);

- To a very largely extent; $4 \%$ - 2 students (2 students with previous studies in pedagogical field).

The evaluated aspects regarding the knowledge of the competencies necessary for a teacher, the ability of students to self-evaluate their own competencies compared to those specific to a teacher, highlight a good capacity for self-assessment of their own competencies necessary for a teacher, according to Figure 6. However, correlating the answers offered regarding the degree of applicability of the contents conveyed during the meetings in a synchronous format with those related to the self-assessment of one's own competencies required by a teacher, we find some contradictory answers, both for students in category $\mathrm{AF}$ and to the pedagogical field. Thus, 6 students cannot assess the degree of applicability of the contents, but consider that they have to a large extent the skills necessary for a teacher. Moreover, out of the 10 students cannot assess whether they have the necessary skills for a teacher, 6 of them consider the degree of applicability of the contents high, 1 student considers it low, 2 students very low and 1 student does not know how to appreciate this aspect.

The development of the pedagogical practice led to several finalities found in the student' answers (89\%):

- The stage of activity;

- The usefulness and content of the curriculum;

- What are the areas of development, the types of learning activities and experiential areas;

- The need to correlate activities with real life;

- Completing an activity observation sheet;

- Organization of activities, thematic projects;

- Method means specific to kindergarten activities;

- The need to use language specific to experiential areas centers of interest, difference between children of 0-3 years old and 3-6 years old;

- Communication with parents; 
- Providing feedback to children.

A percentage of $11 \%$ of students (2 students with previous studies in pedagogical field and 3 students with previous studies in another field) consider that they have not learned anything in the pedagogical practice, one of them appreciating that he has to a very large extent the competencies of a teacher, 3 students to a small extent and one of them cannot pronounce. At the same time, for one of them the degree of applicability of the contents is high, another considers it low, another very low and two students cannot pronounce.

Causes specified by the students: studies in another field, non-participation in all meetings within practice. We would like to mention that, as practice tutors, we have drawn a set of causes that generate the appearance of these difficulties we mention here: the lack of individual study to deepen notions, the need to practice, deepen knowledge, contextualizing them in the direction of knowledge transfer and skills.

\section{Conclusions}

In conclusion, $49 \%$ of the surveyed students consider as effective the current way of carrying out the pedagogical practice. However, given that there are requests for the presentation of several videos with concrete activities in kindergarten, we consider that they also appreciate positively the way the pedagogical practice is carried out (9\%) because these aspects have already been found, following with their presentation. It is necessary to resume the presentation of the curriculum for early education, the completion of some activity projects. The students' suggestions are correlated with the difficulties encountered by them, this fact proving a good capacity for self-assessment regarding their own needs.

This analysis highlights the need for introspection by each student on having the necessary skills for a teacher, designing activities in pedagogical practice to identify the specific skills of a teacher, encouraging students to capitalize and develop their own skills.

The answers given by the students show that all contents circulated had an impact on them. For future activities, we aim to use tools of self-assessment, reflective components and highlight the degree of involvement in teaching activities. Clearly, the fundamental steps to operationalize the curricular requirements (curriculum design and development) will be constantly monitored considering that "both processes are mandatory and very present in the daily work of educators" (Tătaru, Glava \& Chiș, 2014, p. 7). At the same time, it is important to keep in mind that "increasing autonomy in learning management has effects on cognitive and motivational processes as well as school performance" (Ceobanu, Cucoș, Istrate \& Pânișoară, 2020, p. 159). The current situation has once again proved the importance of introducing in the school curriculum of several subjects and areas that contribute to self-education (Stănescu, 2017).

We consider that the limits highlighted in the study can be removed by a careful reading of curricular documents, by involving students in task involvement in interactive activities organized synchronously and asynchronously and by identifying new educational resources that can be subject to debate, weekly, in a pedagogical practice class.

"Education can no longer be limited to inducing a reactive adaptation necessary for students in a certain period situation but to achieving an effective proactive adaptability necessary for existence and development in a changing society. Therefore, they become valuable:

- Not only bending to environmental conditions (=adaptation), but especially their anticipation and influence;

- Not only the response to external factors, depending on the individual endowment (=reaction), but also construction, creating conditions for optimal development through a transactional process, proactivism (=proACTION);

- Not only to achieve objectives in terms of cost data (=efficiency), but to fulfilcertain roles and update diverse skills in situations and contexts not only existing or predictable but also possible (=effectiveness).

Specialists in the theory of change consider that the change of knowledge is the easiest to achieve and requires the shortest time. Attitudes and individuals follow." (Bocoș et al. 2015, p. 95).

Authors note: The authors have equal contributions to this article.

Luciana Truta is an associate teacher at the Department of Educational Sciences, Babeș-Bolyai University, Cluj-Napoca. She has a degree in educational science and her fields of interest include: class management, institutional management, efficient methods of institutional communication and 
identifying procedures for streamlining the functionality of the kindergarten.

Olga Chiș is a senior lecturer at the Department of Educational Sciences, Babeș-Bolyai University, ClujNapoca. She graduated Ph.D. in educational sciences and her fields of interest include: parental education, children's literacy, assessment of children in kindergarten and primary school.

\section{References}

Bocoş, M., Răduţ-Taciu, R., \& Chiş, O. (2015), Individual changes and organizational change. Exemplifications for the Romanian preschool teaching system. Procedia Social and Behavioral Sciences, 209 (2015), 90-95.

Bocoş, M. (coord.), Răduţ-Taciu, R., \& Chiş, O. (2015), Tratat de management educațional pentru învățământul primar și preșcolar. Pitești: Paralela 45 Publishing House.
Ceobanu, C., Cucoș, C., Istrate, O., \& Pânişoară, I.-O. (coord.) (2020), Educația digitală, Iași: Polirom Publishing House.

Chiș, O., Jucan D., Catalano, C.V., \& Dragoș, V. (2017), Ghid de practică pedagogică pentru învățământul primar. Pitești: Paralela 45 Publishing House.

Stănescu, M. (2017). Beyond the Given Form. Theatre Pedagogic as Connecting Element Between the Known and the Unknown. Folia linguistica et litteraria, 18, 131-148.

Tătaru, L., Glava, A., \& Chiș, O. (2014), Piramida cunoașterii. Pitești: Diamant Publishing House.

Truța, L., (2012), Instrumente eficiente ale managerului de grădiniță. Cluj-Napoca: Presa Universitară Clujeană Publishing House.

Info UBB. Noua Pedagogie Universitară. Available at: https://www.ubbcluj.ro/ro/infoubb/noua_pedagogie_un iversitara/ (accessed at 25.11.2020) 


\section{Online Education - a Reality of Our Times}

\section{Cristina Ispas}




\title{
Online Education - a Reality of Our Times
}

\author{
Cristina Ispas ${ }^{a^{*}}$ \\ ${ }^{a}$ Educational Sciences Department, UBB University Studies Center from Reșița, Traian Vuia Square, No.1-4, Reșița, 320085, Romania \\ *Corresponding author: cristina.ispas@ubbcluj.ro
}

\section{Abstract}

Keywords:

online education; distance learning; technologies and means of communication; internet.

Zusammenfasung

\section{Schlüsselworte:}

Online-Bildung; Fernunterricht; Technologien und

Kommunikationsmittel; Internet.
The current context generated by the COVID 19 pandemic has determined, as far as education is concerned, a substantial orientation of didactic activities towards online education. On a par with teachers, the students and parents were confronted with the more or less familiar reality of online education. The process of adaptation to this type of education was not deprived of obstacles but was also a source of satisfactions on the professional and personal level. The present study highlights the characteristics of the online education, the need for online education in the COVID 19 pandemic context, as well as the advantages and disadvantages brought about by this type of education.

\section{Introduction}

Online education represents one of the most exciting forms of distance education. Understood as an alternative or complementary form of instruction, distance education must be designed and implemented so that it observes all the quality pedagogical standards, meant to lead towards the best results which can be obtained in the teaching-learning-evaluation activity. Distance education undeniably brings about a series of advantages and limits to the education field. Their analysis allows the continuous improvement of theories and practices in the field of online education.

\section{Theoretical foundation}

The literature offers numerous definitions attempting to clarify the meaning of online education as the current form of distance education. According to these definitions, distance education is understood as:

- "no more than a hodgepodge of ideas and practices taken from traditional classroom settings and imposed on learners who just happen to be separated physically from an instructor" (McIsaac \& Gunawardena, 1996, p.5),
- "Distance education is a form of education in which the participants in educational process - teacher and learners are physically separated and communicate by different means and at different times." (Kiryakova, 2009, p.29)

- "Distance education is teaching and planned learning in which teaching normally occurs in a different place from learning, requiring communication through technologies as well as special institutional organization" (Moore \& Kearsley, 2012, p.2).

The concept of "distance education" often used as a synonym for online education has been known and applied in practice for at least 200 years. This concept originates in the educational practices of the United States in the 1800's when the teachers and the students from the University of Chicago, who were in different locations, tried to stay connected with the study programs from a distance by mail. In those times, the teachers used printed materials and postal services for what was called mail education. (Mclsaac \& Gunawardena, 1996). 
The occurrence and development of the radio a century later facilitated the communication between people who were usually away from one another. Understanding the huge potential that the radio could offer, as back as 1921 the University in Salt Lake City made all the preparations to obtain the licence for broadcasting certain educational radio programmes. Distance education thus recorded a new stage in its evolution. Grace to the radio, the oral communication wins an important place within distance education. The emotion transmitted through paraverbal language accompanied the verbal message, being thus much easier to perceive or understand on the radio. Since its very appearance, the radio became extremely attractive and popular among population. It was not necessary any more to be able to read, write or stay near a radio set, you could simply listen to it. The success of these radio broadcasts was also amplified by the fact that the educational broadcasts were embedded or interbedded with short latest news, musical or entertainment shows etc.

Step by step, the radio started to broadcast to all the corners of the world and its messages were received by numerous listeners, facilitating people's access to information, education, culture.

In Romania, even since 1930, at the proposal of Professor PhD Dimitrie Gusti, the founding father of Romanian sociology, the Chairman of the Romanian Society of Radio Broadcasting at that time, they organised two radio conferences for the inferior and superior classes.

Neil Postman (1992) in his paper titled Technopoly: The surrender of culture to technology emphasises the fact that "it is not always clear, at least in the early stages of a technology's intrusion into a culture, who will gain most by it, and who will lose most." (p. 12)

Despite the time passed, even today there are numerous experiences where the radio is used for broadcasting certain educational contents. In the study The Return of Educational Radio? (2008), Sally D. Berman examines the way in which one of the traditional technologies of distance education, the radio, is used in the 21 st century for educational purposes in Asia, Africa and the Western world. The author suggests that the developed countries can learn from the developing countries today's use of the radio for educational purpose and that the radio deserves a higher attention as a means able to offer educational opportunities to the rural and isolated peoples throughout the world.

TV distance education had a great success due to the multiple opportunities offered by television which combines sound with image, succeeding in transmitting information, feelings, in influencing behaviours. In 1945 the University of Iowa obtained the first licence which allowed it to use television for educational purposes enabling it to open its gates to the public interested in knowledge, to the community. Thus, by means of television, there were offered broadcasts with general educational character on certain topics, on the one hand, and on the other hand they proposed broadcasts designed and realised taking into account the curriculum in force in the preuniversity and university system. A series of research surveys (.....) have shown that the results obtained by TV education are similar to those obtained in the traditional system when they are taken into account. By means of television, using the image and the sound we can reach all the components of education: intellectual, moral-civic, physical, artistic, aesthetic, etc. Likewise, television allowed the representation, in a very suggestive way, of some concepts, abstract ideas which explained with the help of moving images, accompanied by music have become more accessible to everyone.

Obviously, the practices in the educational space regarding the design and implementation of distance education existed long before the appearance of the internet. The development of distance means of communication, either by mail at the beginning and by radio and television or the computer technologies in the case of the latest generation, had a huge impact on people's lives, including education and the possibility of their use for educational purpose.

In the past 10 years, a series of concepts were used as synonyms for online education, such as: E-learning (or eLearning), multimedia learning, technologyenhanced learning (TEL), computer-based instruction (CBI), computer-based training (CBT), computerassisted instruction or computer-aided instruction (CAI), internet-based training (IBT), web-based training (WBT), virtual education.

Starting from the concepts that compose the phrase "online education", it can be intuitively defined as a way of developing an instructional-educational process by means of computer technology and communication on the internet. The researchers of Babeș-Bolyai University in Cluj-Napoca (Opre,. et al., 
2020) provide an alternative, more complex definition, according to which online education is a "didactic strategy (paradigm), ad-hoc designed for teachinglearning-evaluation based on informational technology, materialized by formative and evaluative sessions carried on online which alternates two types of instructional activities: synchronous and asynchronous."

The literature highlights that the development of online courses cannot be done overnight (https://www.informingscience.org/Publications/3502 ). A study conducted by the National Centre for Educational Statistics - NCES in the USA found that the main factors which the higher educational institutions in the USA to offer students online courses refer to the satisfaction of the students' demands for flexible programs (68\%), offering access to university studies also to students who otherwise could not have access (67\%), offering students more courses (46\%), aiming at increasing the students number at the same time (Parsad, Lewis, \& Tice, 2008).

The universities were among the first institutions interested in offering distance courses to their students, grasping the enormous opportunity that internet offers, in order to meet students' need for training, being disposed to invest in top technology in order to ensure the high quality standards for the design and development of the online courses.

The end of 2019, but especially 2020 would bring the most radical changes in the economic-socialcultural life worldwide by the emergence of the COVID-19 pandemic. Education, besides numerous other sectors of public life, had to be redefined and opened wide the gates of the online education. The development of informational and communication technologies offered teachers the opportunity to change their pedagogical approaches (Thamarana, 2016).

In the US, higher education, even before the emergence of the COVID-19 pandemic, online education represented the segment with the most rapid growth and the demand continues to grow (Seaman, Allen și Seaman, 2018; Ginder, Kelly-Reid și Mann, 2019). In the context of the COVID-19 pandemic, universities were the first who reacted positively, even from the beginning, to the new conditions and developed online courses for students, using various educational platforms for this purpose.

\section{Research methodology}

The purpose of this research consists in identification of the students' perception referring to the online education developed in the context of COVID 19 pandemic. In this direction we have aimed at the following specific objectives:

OS1: identifying students' opinions for continuing teaching activities in the form of online education;

OS2: emphasising some particular aspects regarding the way in which the online university education was achieved during the COVID -19 pandemic period, referring to the types of activities (synchronous and asynchronous), the duration and timetable of activities, the means (instruments) of online connection used by the students;

OS3: specifying the difficulties encountered in the online education by the students

The research was conducted in the period June 2020 - October 2020.

The aimed target group was made up of 200 students from 5 universities in Romania, from different programs of study. There were only 196 valid questionnaires (respectively 196 students, from the 200 initial ones, have answered the questions in the questionnaire; 4 students have sent incomplete questionnaires, which led to the rejection of these questionnaires from the research). The questionnaire was anonymously completed by 196 students participating in the research in the period March 2020October 2020. According to the gender, in the research, there were 124 female respondents $(63,27 \%$ of the total sample) and 72 male respondents $(36,73 \%$ of the total sample). Regarding the residence environment, 93 people (47, $45 \%$ of the total sample) live in the rural area, and 103 (52,55\% of the total sample) live in the urban area. The students participating in the research have ages from 20 to 49 years and regarding the year of study, the situation is as follows:

Table 1. The structure of research participants according to the year of study at the university

\begin{tabular}{lll}
\hline Year of studies & $\begin{array}{l}\text { No. of } \\
\text { students }\end{array}$ & $\%$ \\
\hline 1st year, BA/undergraduate level & 37 & $18.88 \%$ \\
2nd year, BA/undergraduate level & 48 & $24.49 \%$ \\
3rd year, BA/undergraduate level & 34 & $17.35 \%$
\end{tabular}


4th year of studies (or 1st year, master)

41

$20.92 \%$

5 th year of studies (or the 2nd year master

$18.37 \%$

Total

196

$100.00 \%$

The used investigation methods are: the study of documents and national and international specialised materials in the aimed field: inquiry-based questionnaire addressed to the students of 5 different universities in Romania.

The questionnaire contained 15 questions among which: 11 content questions (opinion questions), closed or semi-open and 3 factual/administrative questions (referring to age, gender, residence environment, field of study and year of study).

\section{Results}

The study of documents has highlighted the need to move to online education during the reference period. Likewise, some definitions for the online education were identified, a short history of the distance education was highlighted, we stated a series of synonyms used for the online education, as well as the theoretical registration regarding of the difficulties of online education.

The data obtained by means of the questionnaire were processed and interpreted quantitatively and qualitatively being presented in this study based on the some items followed during the research.

Item1. During the period 11 March 2020 October 2020, during the COVID-19 pandemic how did the university courses, which you attended, developed?
All the students participating in the research declare that the didactic activities they participated in during the period 11 March 2020 - October 2020 were developed exclusively online.

Item 2. How important is in your opinion to continue the didactic activity under the form of education online?

Table 2. Results obtained for the item no. 2

\begin{tabular}{lll}
\hline & $\begin{array}{l}\text { No. of } \\
\text { answers }\end{array}$ & $\%$ \\
\hline Very important & 156 & $79.59 \%$ \\
Important & 29 & $14.80 \%$ \\
Moderate Importance & 11 & $5.61 \%$ \\
Less important & 0 & $0.00 \%$ \\
Totally unimportant & 0 & $0.00 \%$ \\
Total & 196 & $100.00 \%$
\end{tabular}

For most of the students to continue studies during the Covid 19 pandemic is important $(14,80 \%$ of the total sample) and very important $(79,59 \%$ of the total sample). An essential role is played by the fact that universities have already had experience regarding the distance education, that is why they could offer, even from the beginning, to their students educational services of high quality, proving involvement, responsibility, flexibility.

Item 3. During the Covid-19 pandemic did you participate in online didactic activities on different platforms or social networks such as Teams, Zoom, Edmodo, Googlemeet, Skype, Facebook, Whatsapp etc.) achieved ...

Table 3. Results obtained for the item no. 3

\begin{tabular}{|c|c|c|c|c|c|c|}
\hline & Always & Mostly & Medium & Scarcely & Never & Total \\
\hline in synchronous way, with the possibility to intervene & 2 & 156 & 23 & 12 & 3 & 196 \\
\hline $\begin{array}{l}\text { (write questions in the chat for teachers/colleagues, to } \\
\text { take the floor etc?) }\end{array}$ & $1.02 \%$ & $79.59 \%$ & $11.73 \%$ & $6.12 \%$ & $1.53 \%$ & $100.00 \%$ \\
\hline \multirow[b]{2}{*}{$\begin{array}{l}\text { in the synchronous way without the possibility to } \\
\text { intervene }\end{array}$} & 3 & 12 & 31 & 147 & 3 & 196 \\
\hline & $1.53 \%$ & $6.12 \%$ & $15.82 \%$ & $75.00 \%$ & $1.53 \%$ & $100.00 \%$ \\
\hline & & & & 18 & 178 & 196 \\
\hline in the asynchronous way (recorded audio-video lessons) & 0 & 0 & 0 & $9.18 \%$ & $90.82 \%$ & $100.00 \%$ \\
\hline in the asynchronous way (others, apart from the recorded & & & & & & \\
\hline audio-video lessons; for instance covering different & 166 & 21 & 6 & 3 & 0 & 196 \\
\hline $\begin{array}{l}\text { materials of the type: word, pdf., power-point, solving } \\
\text { various homework posted by the teachers? }\end{array}$ & $84.69 \%$ & $10.71 \%$ & $3.06 \%$ & $1.53 \%$ & $0.00 \%$ & $100.00 \%$ \\
\hline Others. Which? & 0 & 0 & 0 & 0 & 0 & 0 \\
\hline Total & $\begin{array}{l}171 \\
87.24 \%\end{array}$ & $\begin{array}{l}189 \\
96.43 \%\end{array}$ & $\begin{array}{l}60 \\
30.61 \%\end{array}$ & $\begin{array}{l}180 \\
91.84 \%\end{array}$ & $\begin{array}{l}184 \\
93.88 \%\end{array}$ & \\
\hline
\end{tabular}


From the data obtained we observe the fact that the synchronous activities prevailed, which allows the interaction of the student with the teachers and colleagues and the asynchronous activities, in which usually the emphasis is put on the individual study of the bibliographic references, on the achievement of assignments. In our opinion, it is a part of the didactic mastery the way in which the teacher guides learning, succeeding to involve students both in the synchronous activities and in the asynchronous ones. The facilities offered by the educational platforms has helped both students and teachers.

Item 4: What was the average time for the synchronous activities?

Table 4. Results obtained for the item no. 4

\begin{tabular}{lll}
\hline & $\begin{array}{l}\text { No. of } \\
\text { answers }\end{array}$ & $\%$ \\
\hline 1 hour or less & 78 & $39.80 \%$ \\
between 1 and 2 hours & 95 & $48.47 \%$ \\
more than 2 hours & 20 & $10.20 \%$ \\
$\begin{array}{l}\text { I did not participate in } \\
\text { synchronous lessons }\end{array}$ & 3 & $1.53 \%$ \\
Total & 196 & $100.00 \%$ \\
\hline
\end{tabular}

According to the students'evidence, most synchronous activities had a duration between 1 and 2 hours. The answer received from the students mostly reflects the number of hours foreseen in the curriculum for a subject of study, which is usually between one or two hours for each activity of course or seminar.

Item 5: Regarding the timetable of the online activities developed in synchronous way, were there any overlaps?

Table 5. Results obtained for the item no. 5

\begin{tabular}{lll}
\hline & $\begin{array}{l}\text { No. of } \\
\text { answers }\end{array}$ & $\%$ \\
\hline Never & 29 & $14.80 \%$ \\
Rarely & 117 & $59.69 \%$ \\
Sometimes & 23 & $11.73 \%$ \\
many times & 18 & $9.18 \%$ \\
Always & 9 & $4.59 \%$ \\
Total & 196 & $100.00 \%$ \\
\hline
\end{tabular}

Generally, the timetable of the online activities, with very few exceptions observes the timetable of face-to-face activities. Consequently, it is natural that the timetable overlaps are occasional and usually at the beginning of the semester and fewer during the semester. The data obtained from the interviewed students confirm this hypothesis, most of them stating that rarely (117 students, respectively $59,69 \%$ of the total sample) there are overlaps in the timetable, while $14,80 \%$ state that there were never overlaps in the timetable.

Item 6. In order to participate in the online didactic activities you usually used:

Table 6. Results obtained for the item no. 6

\begin{tabular}{|c|c|c|c|c|c|c|}
\hline & $\begin{array}{l}\text { Alwa } \\
\text { ys }\end{array}$ & $\begin{array}{l}\text { Mostl } \\
\mathrm{y}\end{array}$ & $\begin{array}{l}\text { Mediu } \\
\mathrm{m}\end{array}$ & $\begin{array}{l}\text { Scarce } \\
\text { ly }\end{array}$ & Never & Total \\
\hline \multirow[b]{2}{*}{$\begin{array}{l}\text { a } \\
\text { computer }\end{array}$} & 23 & 17 & 41 & 48.00 & 67 & 196 \\
\hline & $\begin{array}{l}11.73 \\
\%\end{array}$ & $8.67 \%$ & $\begin{array}{l}20.92 \\
\%\end{array}$ & $\begin{array}{l}24.49 \\
\%\end{array}$ & $\begin{array}{l}34.18 \\
\%\end{array}$ & $\begin{array}{l}100.00 \\
\%\end{array}$ \\
\hline \multirow[b]{2}{*}{ a laptop } & 62 & 45 & 33 & 37.00 & \multirow[b]{2}{*}{$\begin{array}{l}19 \\
9.69 \%\end{array}$} & 196 \\
\hline & $\begin{array}{l}31.63 \\
\%\end{array}$ & $\begin{array}{l}22.96 \\
\%\end{array}$ & $\begin{array}{l}16.84 \\
\%\end{array}$ & $\begin{array}{l}18.88 \\
\%\end{array}$ & & $\begin{array}{l}100.00 \\
\%\end{array}$ \\
\hline \multirow[b]{2}{*}{ a tablet } & 29 & 36 & 16 & 41.00 & 74 & 196 \\
\hline & $\begin{array}{l}14.80 \\
\%\end{array}$ & $\begin{array}{l}18.37 \\
\%\end{array}$ & $8.16 \%$ & $\begin{array}{l}20.92 \\
\%\end{array}$ & $\begin{array}{l}37.76 \\
\%\end{array}$ & $\begin{array}{l}100.00 \\
\%\end{array}$ \\
\hline \multirow{2}{*}{$\begin{array}{l}\text { a } \\
\text { smartpho } \\
\text { ne }\end{array}$} & 72 & 41 & 23 & 31.00 & 29 & 196 \\
\hline & $\begin{array}{l}36.73 \\
\%\end{array}$ & $\begin{array}{l}20.92 \\
\%\end{array}$ & $\begin{array}{l}11.73 \\
\%\end{array}$ & $\begin{array}{l}15.82 \\
\%\end{array}$ & $\begin{array}{l}14.80 \\
\%\end{array}$ & $\begin{array}{l}100.00 \\
\%\end{array}$ \\
\hline \multirow{2}{*}{$\begin{array}{l}\text { Others. } \\
\text { Which? }\end{array}$} & 0 & 0 & 0 & 0 & 0 & 0 \\
\hline & $0.00 \%$ & $0.00 \%$ & $0.00 \%$ & $0.00 \%$ & $0.00 \%$ & $0.00 \%$ \\
\hline \multirow[b]{2}{*}{ Total } & 186 & 139 & 113 & 157 & 189 & 196 \\
\hline & $\begin{array}{l}94.90 \\
\%\end{array}$ & & $\begin{array}{l}57.65 \\
\%\end{array}$ & $\begin{array}{l}80.10 \\
\%\end{array}$ & $\begin{array}{l}96.43 \\
\%\end{array}$ & $\begin{array}{l}100.00 \\
\%\end{array}$ \\
\hline
\end{tabular}

From the data analysis we observe the students' preference for the mobile means of communication, especially smartphone and laptop. Obviously, each of these means have their technical characteristics which help or limit the development of the didactic act by their means.

According to the evidence of the students participating in the research, most of the synchronous activities use the phone which allows rapidly the connection form wherever they are, but for the asynchronous activities (especially when they filled in hangouts or wrote essays, abstracts etc) they prefer the laptop or the computer. 
"Due to the pandemic crisis there has been a huge, disruptive shift from existing educational system to online education system" (Soni, 2020).

Any didactic act supposes to face some challenges, to answer some difficulties. From this perspective the interviewed students have offered the following answers:

Item 7. What difficulties did you encounter in the online courses during the Covid 19 pandemic period?

Table 7. Results obtained for the item no. 7

\begin{tabular}{lll}
\hline & $\begin{array}{l}\text { No. of } \\
\text { answers }\end{array}$ & $\%$ \\
\hline I have not encountered difficulties & 56 & $28.57 \%$
\end{tabular}

I have not encountered difficulties

56

$28.57 \%$

Difficulties connected to the acquainting to the platform on which the didactic activities were done;

Difficulties in the creation of an account and logging on the platform;

Difficulties connected to the operation

of the

computer/laptop/tablet/smartphone;

Difficulties connected to the internet operation;

Difficulties connected to the operation of the used platform on the development of didactic activities;

Difficulties connected to the timetable;

Personal difficulties regarding the participation in the online courses (socio-medical problems, tiredness, unability to concentrate during the course, job etc.);

$17.86 \%$

Others. Which?
$0.00 \%$

If 56 students $(28,57 \%$ of the total sample $)$ consider that they did not meet difficulties regarding the development of online didactic activities, the others identify in average 3-4 problems they met and which they should face. It is true that when the problems met are perceived as having a high degree of difficulty or they are very easy they tend to generate demotivation among the students, leading to the installation of hopelessness, despair, apathy or even indifference. This is why it is important to have the support of the teachers and their colleagues in solving some inherent problems.

\section{Discussions and conclusions}

The spreading of the coronavirus infection has determined teachers and students to rapidly adapt to the new situation, in which school continues even outside the school walls and traditional classrooms, using online knowledge and instruments accessible to everyone. The experience to develop educational activities using digital resources and instruments prevailingly existed in the university educational system but in a net inferior scale are to be found in the pre-university system even during the period before the start of the COVID -19 pandemic. The exclusive use in the design and implementation of didactic activities of digital resources and instruments during the coronavirus pandemic has constituted the novelty element but also of high pressure on the educational system, revealing vulnerable aspects connected to the school infra-structure, of digital endowment that students and teachers, of the discrepancies existing between schools and families in the urban and rural area, highlighting the difficulties concerning the implementation of online education, but also the solutions found in order to surpass them, true "challenges that teachers, students, parents and decision-makers try to face in the rapid rhythm in which they appear, manifesting in variable proportions, the availability, interest, pedagogical mastery, inventiveness". (Botnariuc et al, 2020, p. 8)

\section{Authors note:}

Cristina Ispas is a Ph.D. University Lecturer at the Faculty of Psychology and Sciences of Education, in Educational Sciences Department (Babeş Bolyai University, Cluj Napoca, Romania). Fields of interest in research: Student Class Management, Pedagogy for Primary and Preschool Education, Teaching Career Management, Inclusive Education.

\section{References}

Berman, S. (June 2008). Technical Report. The Return of Educational Radio?, Available online at: http://www.irrodl.org/index.php/irrodl/article/view/563 $/ 1038$ (accessed at 14.10.2020).

Ginder, S., Kelly-Reid, J., \& Mann, F. (2019). Enrollment and employees in postsecondary institutions, fall 2017; and financial statistics and academic libraries, fall 2017. Washington, D.C.: U.S. Department of Education. Available online at: https://nces.ed.gov/ pubs2019/2019021REV.pdf. (accessed at 15.10.2020).

Kiryakova, G. (2009). Review of distance education, Trakia Journal of Sciences, Vol. 7, No. 3, pp 29-34, Available online 
https://www.researchgate.net/publication/279448170_ Review_of_distance_education (accessed at 15.09.2020).

McIsaac, M. S., \& Gunawardena, C. N. (1996). Handbook of research for educational communications and technology: A project of the association for educational communications and technology. New York, NY: Simon \& Schuster Macmillan.

Parsad, B., Lewis, L., \& Tice, P. (2008). Distance education at degree-granting postsecondary institutions: 2006-07, National Center for Education Statistics Institute of Education Sciences, Available online at: https://nces.ed.gov/pubs2009/2009044.pdf (accessed at 20.09.2020).

Postman, N. (1992). Technopoly: The surrender of culture to technology. New York: Vintage books.

Seaman, J., Allen, I. E., \& Seaman, J. (2018). Grade increase: tracking distance education in the United States. Babson Survey Research Group. Available online at: https://onlinelearningsurvey.com/ reports/gradeincrease.pdf. (accessed at 18.08.2020).

Soni, V. D. (2020). Global Impact of E-learning during COVID 19, Available online at: https://papers.ssrn.com/sol3/papers.cfm?abstract_id=36 30073 (accessed at 12.10.2020).

Thamarana, S. (2016). Role of E-learning and Virtual Learning Environment in English language learning, Available online at: https://www.researchgate.net/publication/305913807_ Role_of_Elearning_and_Virtual_Learning_Environment_in_Engli sh_language_learning (accessed at 25.09.2020).

Academia Română (2020) Punct de vedere privind educația on-line Available at: https://academiaromana.ro/mediaAR/pctVedereAR/202 0/d0728-Punct_de_vedere_Educatia -online_si_educatia_in_clasa.pdf (accessed at 16.10.2020). 


\section{The Role Of Literature As Vocabulary Teaching} Instrument Of A Foreign Language In Middle School

Torkos Henrietta, Torkos Antonela 


\title{
The Role Of Literature As Vocabulary Teaching Instrument Of A Foreign Language In Middle School
}

\author{
Torkos Henrietta $^{a^{*}}$, Torkos Antonela ${ }^{b}$ \\ ${ }^{a}$ Aurel Vlaicu University from Arad, Faculty of Educational Sciences, Psichology and Social Assistance \\ ${ }^{b}$ Ion Creangă Highschool, Curtici, Arad \\ *Corresponding author: torkos_henriette@yahoo.com
}

\section{Abstract}

\section{Keywords:}

vocabulary; language; literature; foreign; middle-school.
Nowadays, most of the time teaching and learning a foreign language is limited to mastering some grammar rules. Both teachers and students prefer this approach to a foreign language because it involves only the application of "rules", of pre-established "schemes" without the need for creativity and skill in communication. Vocabulary intensifies our ability to function in a complex world, helping us to express ourselves clearly and concisely. Without assimilating enough vocabulary, students cannot have relevant communication, cannot express their ideas and cannot understand each other. On the other way, literature unites the past with the present and makes us aware of our value. It not only provides information but also provides a closer look at things. It reflects the state of a society, its values, strengths and weaknesses. literature is an authentic material that exposes the student to everyday vocabulary. The reader comes into contact with the thoughts, feelings and traditions of the characters being thus exposed to a varied lexical field. Literature is a useful tool in the learning process and due to the impact it has on the reader. The aim of this brief study is to investigate the efficiency of using literary works in teaching vocabulary. There was a number of 725 th and 6th graders that participated to the research, from a midlle school within Arad county. The preliminary results, after the intervention, show that pupils from the experimental group became more passionate about reading, have become more creative and have enriched their cultural baggage.
Zusammenfasung

\section{Schlüsselworte:}

Wortschatz; Sprache; Literatur; Fremdsprache; Mittelschule.
Heutzutage beschränkt sich das Lehren und Lernen einer Fremdsprache meistens darauf, einige Grammatikregeln zu beherrschen. Sowohl Lehrer als auch Schüler bevorzugen diesen Ansatz gegenüber einer Fremdsprache, da er nur die Anwendung von "Regeln", von vorher festgelegten "Schemata" beinhaltet, ohne dass Kreativität und Kommunikationsfähigkeiten erforderlich sind. Der Wortschatz stärkt unsere Fähigkeit, in einer komplexen Welt zu funktionieren, und hilft uns, uns klar und präzise auszudrücken. Ohne genügend Vokabeln aufzunehmen, können die Schüler keine relevante Kommunikation haben, ihre Ideen nicht ausdrücken und sich nicht verstehen. Andererseits verbindet die Literatur die Vergangenheit mit der Gegenwart und macht uns unseren Wert bewusst. Es bietet nicht nur Informationen, sondern auch einen genaueren Blick auf die Dinge. Es spiegelt den Zustand einer Gesellschaft, ihre Werte, Stärken und Schwächen wider. Literatur ist ein authentisches Material, das den Schüler mit dem alltäglichen Wortschatz vertraut macht. Der Leser kommt mit den Gedanken, Gefühlen und Traditionen der Charaktere in Kontakt, die auf diese Weise einem abwechslungsreichen lexikalischen Feld ausgesetzt sind. Literatur ist ein nützliches Werkzeug im Lernprozess und aufgrund ihrer Auswirkungen auf den Leser. Ziel dieser kurzen Studie ist es, die Effizienz der Verwendung literarischer Werke im Vokabeltraining zu untersuchen. Es gab eine Reihe von 72 Füntt- und Sechstklässlern, die an der Untersuchung teilnahmen, von einer Mittelschule im Landkreis Arad. Die vorläufigen Ergebnisse nach der Intervention zeigen, dass Schüler aus der Versuchsgruppe leidenschaftlicher lesen, kreativer geworden sind und ihr kulturelles Gepäck bereichert haben.

\section{Introduction}

Vocabulary is viewed as the main topic when it comes to new language acquisition. It's difficult to communicate something specific and understand what others say if you don't dominate a specific number of words to get your point across and in a similar tendency o comprehend the others. Regardless of whether we are discussing the primary language or another dialect we are attempting to learn, correspondence depends on words. At the point when a youngster begins conveying a message, he utilizes words to send his message.

When referring to second language acquisition, scientists have demonstrated that having a decent information on jargon is a stage forward in getting the language while its absence, it's an intense deterrent. There are numerous speculations about the most ideal 
approaches to train jargon and the etymologists came up with their own researches or encounters. Yet, once in a while, what's best for a few, is unseemly or hard for other people. One thing that is certain is that there are a few perspectives that must be considered when managing jargon and these are: age, social foundation, local language, fitting procedures. (Barton, 2001)

\section{Theoretical foundation}

The main explanation behind learning an unknown dialect is to impart. Correspondence implies understanding the message somebody needs to pass on to you and having the option to react, that is, offer a conceivable response. To do that, mastering of vocabulary is required. Jargon is "the study of words", and alludes to knowing a word, knowing its importance and having the option to fit it in the unique situation. For the most part, realizing a word includes knowing its structure and its significance at the essential level. In more profound viewpoints it implies the capacities to know its:

- Meaning, i.e., relate the word to an appropriate object or context

- Usage, i.e., knowledge of its collocations, metaphors and idioms, as well as style and register (the appropriate level of formality), to be aware of any connotations and associations the word might have

- Word formation, i.e., ability to spell and pronounce the word correctly, to know any derivations (acceptable prefixes and suffixes),

- Grammar, i.e., to use it in the appropriate grammatical form.

There are various methodologies and exercises that can be utilized by educators to show writing: the data-based methodology, the language-based methodology, the individual reaction approach, and the expressive methodology. (Bedi, 2011)

The data-based methodology is a method of training information about writing while writing is viewed as a wellspring of data to understudies. Perusing is significant, however found in close association with other open abilities, for example, composing, talking and tuning in, or suitable utilization of language. The instructor assumes significant part in this methodology. The methodology gives educators classroom focused exercises.

The Language-Based Approach means that the exercises identified are: conceptualizing, guided drama and short conversations. This methodology improves student's language capability. This methodology could improve the advancement of language capability. Through this methodology, students were required to improve their language capability by practicing the objective language. Teachers should go about as the fundamental direction to lead this methodology in the study hall and to motivate students to pay attention to the language. This would urge the understudies to utilize new words routinely and they can improve their language.

The Personal Response Approach depends on individual's translation and reaction of a solitary scholarly.

The Stylistic Approach is concerned about the utilization of phonetic apparatuses to investigate scholarly messages. It drives students into full arrangement and enthusiasm for writing.

We barely at any point envision utilizing abstract writings as material for educating jargon. The abstract works give a wide range of registers that can make the procurement cycle more fascinating for the understudies.

There are loads of reasons why scholarly messages ought to be utilized to instruct jargon:

- Authentic material

- Cultural information

- Natural language

- Different drawing in topics

- Illustrations

- Language in setting

- Personal association

- Creativity improvement (Daskalovska \& Dimova, 2012)

In the following, there is going to be presented a brief list of instruments to pick as materials for instructing:

Books: The utilization of books as materials for language instruction end up being a suitable method. The books ought to be mindfully chosen to make the understudies' perusing drawing in and spurring. By utilizing the novel as material for learning a subsequent language, students figure out how to see the world from various perspectives, can think of their 
own perspective identified with a character or circumstance, can expand their social standpoints.

Verse: Using verse to encourage language allows the understudies to communicate inventively and openly without the limitations of exacting punctuation rules.

Sonnets: permit the understudies to focus harder on familiarity as opposed to exactness. By their short structure, they keep the perused from getting drained or overwhelmed. Bringing sonnets as material for training a subsequent language resembles taking natural air in the wake of investing a lot of energy in.

Short-Stories: Engaging, short and hilarious, short stories are a suitable decision as material for language learning. On account of their length, they can be perused all through a couple of classes and can build up a proper demeanor towards learning.

Dramatization: One of the most alluring and energizing methods of language learning. It allows the understudies to find themselves, their capacities, or, despite what is generally expected, to become whoever they feel like. Dramatization is certainly an innovative method to get familiar with a subsequent language. The understudy isn't confined, however allowed to communicate and his sentiments. Dramatization as a training method establishes strong scholarly and passionate conditions that urge understudies to think. (Harmer, 2007)

These types of texts present various linguistic forms, uses, stylistics and rules of the written language as well as cultural language enrichment. They reflect the traditions, the customs and the way characters communicate, which enables them to understand the difference between referential and representational language. In this way, they learn that language can involve, and words can mean much more than explained in a dictionary, i.e., they go beyond the referential use of the words. While reading the texts they become engaged in the plot and forget about the difficulties and inhibitions they might have about grammatical rules and vocabulary. When choosing a text, the teacher should always bear in mind that the students' beliefs about the usefulness of the text are very important, which means choosing the text together and discussing the benefits from it. Linguists claim that if the text provides good stimuli for personal involvement, it will without doubt contribute to higher linguistic competences of the reader/learner.
Another goal of using literature is to develop a habit of reading. As many students would agree, extensive reading is the best way to acquire a language, but this should be preceded by developing good reading strategies and ability to make good choice of books according to the difficulty level and the linguistic knowledge of the learner. (Enever, 2011)

The literature feeds the imagination and the thinking skill, it promotes personal growth, it makes the learners think critically, support their opinion, discuss and become good readers. It is a good authentic material and provides authentic input for language learning. It enables students to be exposed to actual samples of real life. It contributes to cultural enrichment in the way that certain aspects of the target culture are introduced and provides a wide range of lexical and communicative options, thus making the learner a more competent speaker of the language by extending its vocabulary and all of the language skills, and finally it involves the reader personally which means it relates his life with the plot of the literary text, which in turn makes the reader eager to find out what will happen next.

\section{Research methodology}

The present brief research aims to investigate the efficiency of using literary works to teach vocabulary in middle school, at foreign language subjects. Many linguists have stated that literature offers a large context for language acquisition.

The participants who took part in the study will be secondary school students, namely a group of $725^{\text {th }}$ and $6^{\text {th }}$ graders. The research isn't outlined only around one literary text that is why several grades will take part in the research. In order to investigate the efficiency of drama as material for teaching vocabulary, the fifth graders and the sixth graders will be part of the experimental and control groups. Thus, the $5^{\text {th }}$ and $6^{\text {th }} \mathrm{A}$ graders were the experimental group, in a number of 35 pupils, and the $5^{\text {th }}$ and $6^{\text {th }} \mathrm{B}$ graders were the control group, in a number of 37 pupils.

The research was conducted during the second semester of the $2019^{\text {th }}-2020^{\text {th }}$ school year. There have been prepared lesson plans both for the experimental and control group based on the curricula. For the experimental group the lesson plans were based on different literary texts (dramas, novels, short stories and poetry) while for the control group teachers stuck to the exercises in the textbook. The language was introduced through different exercises and activities 
based on the literary texts. For the warm ups there have been used different activities and games: role plays, miming, who's telling the truth, sentence sequence, predicting activities based on pictures, etc. The new language was usually introduced in the pre-reading activities in all sorts of exercises and games, and have been reinforced during the post-reading activities.

In order to investigate the above-mentioned variables, we are going to present the effect of drama on the development of vocabulary on the sample.

Figure 1 . The outcomes of drama use in the $5^{\text {th }}$ and $6^{\text {th }}$ grade

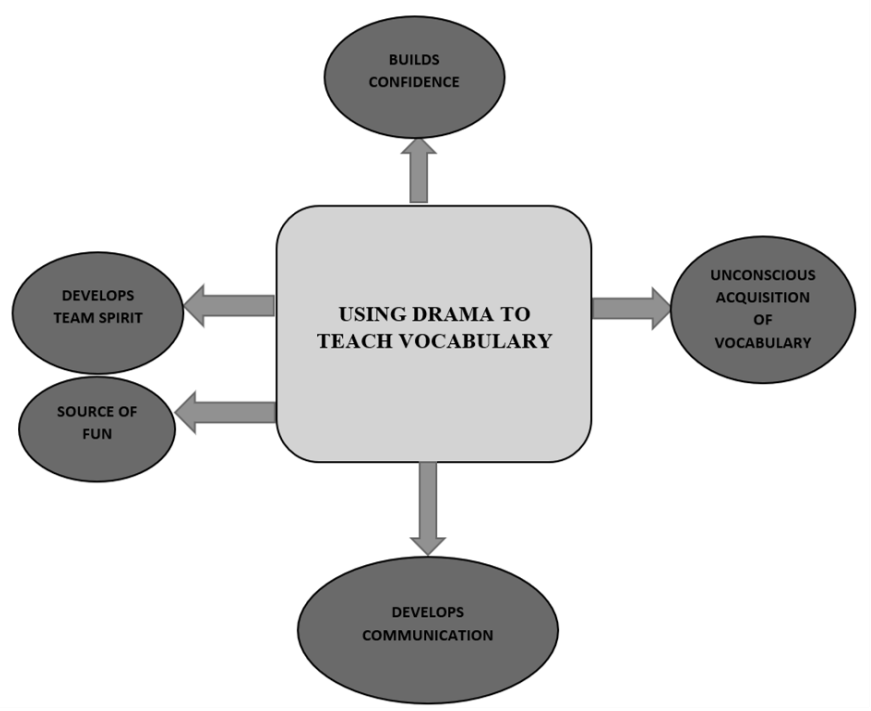

The main aims of the drama lessons that were used in the experimental group, were:

- To build confidence in using accurate reproductions

- To understand main ideas and details in different kinds of dramatic scripts

- To speak clearly enough (pronunciation, stress, intonation) to be understood by classmates and audience

- To acquire good speaking and listening habits to understand, enjoy, and appreciate dramatic texts

- To build awareness and an appreciation for the arts.

In both classes belonging to the experimental group, English is studied as a foreign language at a beginner level, one of the titles of the drama lesson that was used during the experiment was: Snow White and the seven dwarfs and the main teaching techniques used were: explanation, individual work, drama.

The objectives of the lesson where drama was used, were:
- To fill in a text the missing information by understanding the meaning from the context

- To make a connection between the Romanian and English titles of cartoons

- To read the script and perform different roles from Snow White and the Seven Dwarfs

- To take risks and demonstrate trust in others while performing

- To co-work for the success of the performance.

The materials that can be used in a lesson similar to this, are: handouts, blackboard, laptop and scripts. After reading the story, teachers can share the script of Snow White's story to the pupils who want to perform and asks them to act the different roles they were given from the story.

\section{Results}

After the experiment that was conducted, we have observed some positive results. Following the use of different types of literary materials (drama, novel, short story, poetry) to classes for a semester as a way to notice the advantages of using this method, we have noticed that pupils have developed some positive competences.

Regarding the use of drama, as it was presented above, we have chosen 1one play as material for teaching, for the beginners, Snow White and the seven Dwarfs. Proving that teaching vocabulary through drama is easier and more relevant than simply using textbooks is not a difficult task to do.

We have had an optional drama course with the sixth graders for several years, called English through drama. Once again, we have to state that personality plays a very important role when talking about language learning acquisition. The extroverts in the class were the ones who always longed for the main roles and were the most enthusiast whenever the teacher came up with a new play. They were the most willing to act out the plays in front of the parents and the other teachers in the school. Thus, every now and then, we used to organize meeting where they performed in front of a larger audience. We have to say that the drama classes gave the students an authentic language learning environment where they forgot about the fears of not being accurate, of not using the correct grammatical structures or the fear of being mocked at by the others. The plays involved everyone and no one had time to pay attention to 
mistakes. On the contrary, it was the right environment to encourage one another, to be sympathetic and why not, give a helping hand. The theatre plays were a motivation for the students to use the language, which was a real encouragement for us.

In order to investigate the efficiency of this method, we chose the fifth and the sixth graders as participants to the study. The fifth and sixth A graders, the experimental group, were taught vocabulary through drama plays for a month while the fifth and sixth B graders, the control group, were taught vocabulary following the textbook as material for acquiring vocabulary. They all had two English classes per week. We prepared lesson plans for the experimental method. The aim was to have the students $t \theta$ acquire a number of words by the end of this research. The lesson plans were introduced by warm ups in order to prepare the students for the English class. Several games were played: miming, acting out, etc. All these games prepared students for the learning activity and gave them courage to let themselves introduced in the topic. The Lead-in activities put the students in contact with the topic they were to study about. The lessons were either introduced through slides or games or even short film scenes. In the practice part, they used the language in different situations. The vocabulary was introduced through games and was rehearsed while acting. They acted out different types of plays which put them into contact with different vocabulary topics.

The control group, followed only the textbooks exercises and were given only the Romanian correspondent of the unknown words without any games or role plays.

By the end of the study, several differences have been noticed.

Figure 2. Competences developed through the experimental stage

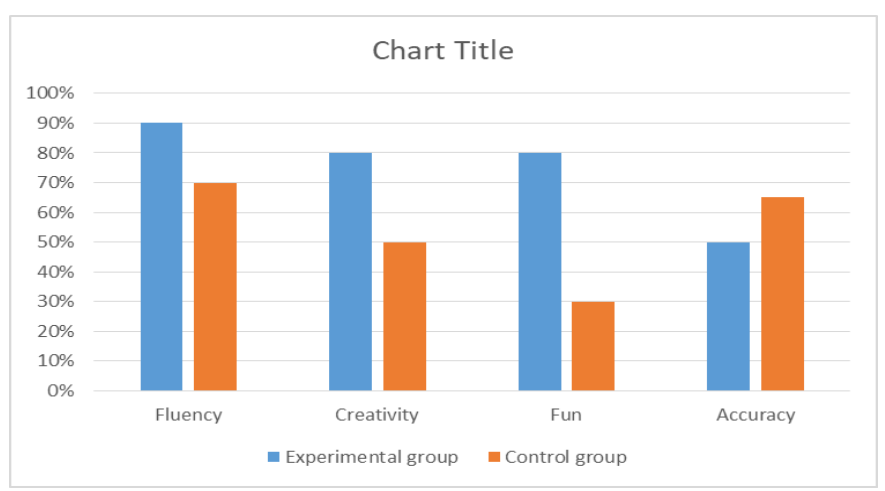

As it shown in the chart above, the experimental group was more confident with using the language.
They were no longer afraid of expressing themselves freely. The fear of making mistakes almost disappeared. The activity focused more on fluency rather than accuracy. Also, they did not have to memorize the new vocabulary because they acquired it unconsciously by games and acting. The meaning of the unknown words was more easily to be remembered because vocabulary was introduced in a context. This type of activity developed a team spirit. Each of them was part of the group with his own responsibilities. Being concerned that all things work out well, they started encouraging one another and used to learnt the lines even for the sake of the team, not to let the others down.

Therefore, all the activities they performed together made them empathize with the others. They became more communicative. They had to come up with ideas related to body movement, to gestures to the interpretation itself and even to give a feedback. Students were more enthusiast and more engaged in the activities because apart from being instructive, they were a source of fun. They did not feel constraint to learn and everything was done in a relaxed, engaging way.

The control group was less motivated to acquire the new vocabulary. They had to memorize the words which turned into short-time memory. The fact that the activities were introduced traditionally, they lacked enthusiasm. Also, school performance, measured in grades after both oral and written evaluation, has positively changed.

The experimental group had no difficulty in expressing themselves orally. They had no problems in reading the dialogues in front of the class because they had lots of practice during the semester. Thus, they were more fluent. The students in the control group paid too much attention on accuracy and were somehow under the pressure of not making mistakes. Thus, they lacked fluency.

For the students in the experimental group, it was easier to use the vocabulary required in context because they practiced during the entire semester. For the students in the control group, it was more difficult to insert the vocabulary in sentences because during the semester they were only given mother-tongue translations. Then, the students in the experimental group were more creative. They made more interesting dialogues because they were used to expressing their opinions or acting different roles. Lastly, because the 
students in the experimental group were not under the pressure of making mistakes, they had fun.

Yet, if we were to refer to accuracy, we have to say that the students in the control group paid more attention to strict rules, to correct word order, to the spelling of the words in their notebooks.

\section{Conclusions}

In conclusion, we consider that teaching vocabulary through drama promotes long-term memorization of vocabulary and keeps the students motivated and engaged in the process of acquisition. It is often written in the specific literature that the best time to start learning a new language is early childhood, because children tend to imitate everything they hear and see, they are like sponges. This statement can be supported by the results of the largest linguistic studies, an Internet survey having more than two thirds of a million respondents, that showed that children until the age of 18 are the most proficient at learning a second language. The study also showed that in order to gain the grammatical fluency of a native speaker one should start learning by the age of 10. (Snow, 2002)

Children learn the foreign language naturally while the adults think more consciously about language. They are more aware of the necessity of learning a new language. The life experience has taught them that in order to follow a particular career, to keep updated to the new technology they need to know a foreign language.

Authors note: The authors have equal contributions to this article.

Torkos Henrietta, $\mathrm{PhD}$, University Assistant at University of Aurel Vlaicu from Arad, with a PhD in
Educational Sciences, specialized in Outdoor Education. Finished bachelor studies in Economics and Educational Sciences, got Masters Degrees both in Actual Tendencies in Romanian literature and Educational Policies. The main fields of interest in research and writing are education and outdoor education. Finished studies in Norway, on education and outdoor learning strategies, also on classroom management. In the present, she works as a University Assistant, holding lectures in pedagogy and psihopedagogy specialties.

Torkos Antonela, a teacher of English and French, also deputy director at Ion Creangă Highschool from Curtici, Arad. Main fields of interest are Theory and methodology of learning and evaluation, Classroom management and Foreign languages.

\section{References}

Barton, J. (2001). Teaching Vocabulary in the Literature Classroom. The English Journal, vol. 90, no. 4, 2001, pp. 82-88. JSTOR, www.jstor.org/stable/821907 (accessed at 10.03.2021).

Bedi, K. (2011). Language acquisition through literature promotes creativity and thinking skill. The Criterion: An International Journal in English, 2(2), pp. 1-6.

Daskalovska, N., \& Dimova, V. (2012). Why should literature be used in the language classroom, Procedia Social and Behavioral Sciences, 46, 1182-1186.

Enever, J. (2011). Early Language Learning in Europe, ELLIE, London, UK: British Council, 2011, p. 157.

Harmer, J. (2007). How to teach English, Essex, Pearson Education Limited, London.

Snow, E. C. (2002). Reading for understanding, Rand Corp, California. 


\section{Scouting Activities in Maintaining the Wellbeing} and the Health of High School Students

Veronica-Oana Irimia 


\title{
Scouting Activities in Maintaining the Wellbeing and the Health of High School Students
}

\author{
Veronica-Oana Irimia ${ }^{a^{*}}$ \\ ${ }^{a}$ Babeș-Bolyai University, Faculty of Psychology and Educational Sciences, 7 Sindicatelor Street, Cluj-Napoca, 400029, Romania \\ *Corresponding author: veronica.moldovan@ubbcluj.ro
}

\section{Abstract}

Keywords:

Leisure activities; non-formal education; scouting activities; scouts - explorers; high school students; wellbeing, health; school performance.

\section{Zusammenfasung}

\section{Schlüsselworte:}

Freizeitaktivitäten; non-formale Bildung; Pfadfinderaktivitäten; Pfadfinder - Entdecker; Lyzealschüler; Wohlbefinden; Gesundheit; schulische Leistungen
The article is part of a larger research, this being the starting point in order to see the efficiency of some activities that are already in development, similarly to those that we are about to suggest in a series of activities packages for free time activities for high school students, that come to meet the problems they are dealing with, but also to support the teachers who have more and more the opportunity (obligation) to make projects for extracurricular activities.

The case study presented analyses the level of wellbeing and health of high school students, members of the National Organisation of Romanian Scouts, Local Centre Târgu-Mureș, named within the association Explorers. We present the activities they have and we follow the dependent variables through a questionnaire.

\section{Introduction}

High school students' problems represent a delicate subject as adolescence is the age of uncertainty, of (self)discovery, of the internal struggle with contradictory feelings, identifying the ideals and the selection of role-models. It is also the age when young people need support, advice and help.

The research on the benefits of outdoor activities, but also from the urban area highlight the valuable contribution that they bring to the individual's health. We wanted to check and highlight these aspects on a local scale, following the footsteps of the high school students who are members of the National Organisation of Romanian Scouts, Local Centre Târgu-Mureș. More to the point, we made a case study in order to see if they have a high level of wellbeing and health.

\section{Theoretical foundation}

The contemporary high school students deal with different problems that generate into undesirable behaviour. Therefore, emotional problems can determine the consumption of cigarettes, drugs, alcohol or the appearance of depression; the antisocial behaviour can lead to isolation, long exposure to computers, tablets, smart phones; the obsession for the physical aspect can have several consequences, like: unrecommended diets, anorexia, bulimia, obesity; family crises can lead to the lack of parental affection and of self-confidence, financial problems.

If we manage to engage them into activities that offer them comfort, an environment for development and affirmation, some of these problems will be surpassed. Such a context is offered by the activities conducted in the environments of the non-formal education, either out-of-school or extracurricular, 
whether conducted by organisations, foundations, associations, etc.

We consider the non-formal education as "the form of education that comprises the sum of the activities and educational influences organised outside of the school system, systematic, deliberate and meant for people of all ages, activities which respond to consonant educational finalities and are connected to each individual's or group's needs of learning, people who share common values and purposes." (Moldovan, V.O., 2017, pp. 15-16)

The Romanian Teaching system offers a more and more declared recognition of the non-formal activities and of the institutions that offer such activities. A relevant example is the fact that once the Order MECTS no. 4.292 has been published, the Programme "The different school" has been introduced. Since then, the project has been in progress, under the name "The different week", being chosen a week dedicated to extracurricular and extra schooling educational activities

(www.cdep.ro/pls/legis/legis_pck.htp_act?ida=10408 ) .

The purpose of these educational activities is the involvement of children, students and teachers in activities that respond to their different interests and preoccupations, to highlight their talents and capacities in different areas, not necessarily in those present in the national curriculum and to stimulate their participation to varied activities, in non-formal contexts.

(www.isjdb.ro/static/files/Anexa_la_Ordin_4496_MECS.pdf).

There are numerous problems raised by the implementation of extracurricular and extra schooling activities. Some of them are related to the lack of funding, the lack of money of the disadvantaged environments' children, but also the teachers' low motivation for developing non-formal activities. So, unfortunately, not all the teachers manage to organise activities like these, even if there are times that require their organisation.

We want to offer a solution by highlighting an organisation that has non-formal activities with children and young people, organisation with which partnerships can be signed in order to achieve joint activities, not only within" The different week", but any time the context allows it.
The National Organisation „Romania's Scouts” (ONCR) is one of the non-governmental organisations acknowledged by the Ministry of Education as being a supplier of non-formal education. This organisation has a history that started more than 100 years ago, being seen, like now as a promotor of an education complementary to school. (www.scout.ro)

Scouting is education for life as, in the young man's education, it completes the family and the school and it develops the self-knowledge, supporting the necessity of finding the new, of participating, exploring, discovering, making and helping. We can say that it is fun with a purpose since by recreation and adventure; scouting reaches its objective of physical, intellectual, social and spiritual development of the youngsters. Scouting is a movement open to all, regardless of race, faith, gender, in accordance with the purpose, the principles and the method conceived by their creator, Robert Baden-Powell. (wWw.scout.org)

\section{Research methodology}

We made a case study based on a social group, more precisely on the National Organisation "Romania's Scouts"(ONCR).

The purpose of the organisation is to contribute to the physical, intellectual, social and spiritual development of children and young people who are prepared to become good citizens and members of the local, national and international community.

Scouting is governed by the „Scout's Law” and by "The Promise of the scout" or "The Pledge", the scouting attains its purpose by combining 7 elements: education through action, teamwork, the symbolic frame, the personal progress system, nature, law and the promise of the scout, the support of the adults. (www.scout.ro)

The plan of the case study consisted of shaping the details about the way of collecting the information that have been used.

First of all, we contacted the ONCR organisation The Local Centre Târgu-Mureș, more precisely the leaders from the Explorers (14/15-18/19 years old). We presented the research we want to make and its purpose - that is to constitute a first step in a larger research that might suggest the use, by the teachers, of different packages for free time activities for high school students. We also presented the questionnaire 
we prepared for the high school students within the organisation, a questionnaire made in Google Forms (Appendix).

We have established together the distribution of the questionnaire on their internal Facebook group, alongside a brief presentation of the case study and its purpose within the research participants. The explorers had one week to fill in and send the questionnaire.

The data obtained was briefly presented to the Explorers and their leaders, on their internal group, since that was their wish. They are also presented here in the chapter Results.

We are going to present the coordinates of the research.

The purpose of this research is to show that the regular participation to the outdoor activities, in nature or within the urban area, more precisely non-formal scouting activities, determine the wellbeing and health of high school students without this affecting the schooling performances, on the contrary, it supports and improves them.

The hypothesis of the research: High school students' participation to non-formal scouting activities contributes significantly to the maintaining of their wellbeing and health.

The independent variable represents high school students' participation to the non-formal, scouting education.

The dependent variables: the level of the wellbeing, health and high school students' performances.

The methods used are part of the scientific research methods, more precisely the case study and the enquiry based on a written questionnaire.

The sample of participants is made up of high school students enlisted within the National Organisation Romania's Scouts, Local Centre TârguMureș at the Explorers age group, therefore 21 scouts with ages between 15 and 19 (Table 1.). They have a seniority as organisation members between 1 and 9 years (Table 2.)., most of them being active also at the younger age groups: Cubs and Scouts.
Table 1. Age distribution

\begin{tabular}{ll}
\hline Age & Frequency \\
\hline 15 ys & 4 Explorers \\
16 ys & 2 Explorers \\
17 ys & 5 Explorers \\
18 ys & 6 Explorers \\
19 ys & 4 Explorers \\
\hline
\end{tabular}

Table 2. Seniority in scounting

\begin{tabular}{cl}
\hline Seniority in scouting & Frequency \\
\hline 1 year & 2 Explorers \\
2 ys & 3 Explorers \\
3 ys & 3 Explorers \\
4 ys & 2 Explorers \\
6 ys & 4 Explorers \\
7 ys & 4 Explorers \\
9 ys & 3 Explorers \\
\hline
\end{tabular}

The content sample represents the activities the scouts attended in the period when they were active members of the organisation.

The scouting activities are based on three principles:

- the spiritual principle - the involvement in the searching of the spiritual values, of life beyond the material world;

- the social principle - participating at the society's development by respecting the dignity of others and the integrity of the world;

- the personal principle - developing personal responsibility and stimulating the desire to express it.) (www.scout.ro)

Currently, ONCR has in progress, at a national level, through the national teams and at a local level tens of activities in various areas: forming stages, activities of developing life abilities, activities of integrating disabled young people, charity activities, ecological activities, civic education, education for the environment, vocational preparing, seminars, workshops, publications (magazines, fliers and brochures), national and international camps, youth exchange, fund raisings and many other activities.

Those from the participants' sample have been involved in numerous activities along the years, 
thematic activities in the above-mentioned areas, came to life in the form of: hikes, camps, national or international gatherings (Jamboree). The percentage of high school students who attended these activities is mentioned in Table 3.

Table 3. Age distribution

\begin{tabular}{lc}
\hline \multicolumn{1}{c}{ Activities with scouts } & The percentage that attended \\
\hline Hikes & $100 \%$ \\
Camps & $70 \%$ \\
National Jamboree & $40 \%$ \\
International Jamboree & $10 \%$
\end{tabular}

In addition to these activities specific to scouting, high school students, the participants to this study, say that they also took part in other activities organised for them and by them within the local centre: rafting and climbing, riding the bicycle, relaxing in nature (hammocking, picnics, games, acoustic concerts).

\section{Results}

With the help of this pedagogical research, we want to highlight if the high school students' participation at non-formal scouting activities contributes significantly to the maintaining of their wellbeing and health, without these affecting the school performances, but on the contrary to support and improve them.

In order to support the results obtained we will use the information offered by the article Benefits of Outdoor Sports for Society. A Systematic Literature Review and Reflections on Evidence (Eigenschenk, B., 2019) where are presented a selection and an analysis of 133 studies. The authors of this study present evidence regarding the importance of physical activity, especially for the physical and mental health and that of wellbeing. They also bring evidence regarding the benefits of outdoor activities.

In order to follow the first dependent variable high school students' wellbeing, we asked them which are the free time activities they practice and offer them a state of wellbeing both from a physical, emotional and social point of view. The most frequently mentioned activity, $38 \%$ from the respondents, was reading, followed by activities with friends (33\%), sporting activities (23\%) and hikes (23\%). Other activities preferred by the Explorers were: watching films and series, climbing, creative activities, listening to music, teamwork, drawing and sculpture, yoga, riding the bicycle and trips.

Most of the activities mentioned are between the most frequently organised within scouting, we can say that this organisation responds to the needs of high school students. Also, based on the studies analysed on the above-mentioned research, we can say that there is evidence of the impact that free time activities have upon the general well-being, the quality of life, happiness and satisfaction. In the same time, physical exercises in natural environments have brought a feeling of revitalising and positive commitment to the participants. Relaxing in nature shows positive effects upon the mood, the endurance, the feelings of revitalisation and a positive commitment. It is also shown that, outdoor activities have effects upon increasing self-esteem, self-confidence, selfefficiency and social efficiency. (Eigenschenk, B., 2019).

We also wanted to observe how often high school students, the participants to the study, have activities in nature, either with the scouts or on their own. The answers are highlighted in Table 4.

Table 4 . How often they practise outdoor activities

\begin{tabular}{cc}
\hline How often & The Explorers' percentage \\
\hline $2 / 3$ times / week & $15 \%$ \\
$1 /$ week. & $20 \%$ \\
$1 / 2$ week. & $45 \%$ \\
$1 /$ week & $10 \%$ \\
$1 / 2$ months & $5 \%$ \\
rarely & $5 \%$
\end{tabular}

As we can notice, most are the ones who have an activity every two weeks.

In order to follow the second dependent variable the health level we asked the explorers 3 questions. The first question takes into consideration their immune system, more precisely if it is or not a strong one, asking them how many times they had a cold or a flu in the last two years.

Table 5. How often they had a cold or a flu

\begin{tabular}{cr}
\hline Frequency & The Explorers' percentage \\
\hline 0 & $20 \%$ \\
1 & $55 \%$ \\
2 & $15 \%$ \\
3 & $10 \%$
\end{tabular}


We can notice in Table 5 that $20 \%$ of the respondents have not had a cold or a flu in the last two years, and that most of them $(55 \%)$ were sick only once. So, we can say that their immune system is a strong one.

We have also asked if they have other health problems. Most of them, $61 \%$ of the Explorers, do not have other health problems, $14 \%$ of the respondents mentioned that they have different allergies, and others suffer from different affections (nearsightedness, gastritis, allergic asthma, anaemia and knee problems).

We asked the Explorers to self-evaluate their health situation on a scale of $1-5$, where 1 is a bad health situation and 5 is a very good health situation. The results are presented in Table 6.

Table 6. Self-evaluated health situation

\begin{tabular}{rr}
\hline & The Explorers' percentage \\
\hline 1 (bad) & $0 \%$ \\
2 & $0 \%$ \\
3 & $10 \%$ \\
4 & $45 \%$ \\
5 (very good) & $45 \%$
\end{tabular}

Analysing the data from these tables we can say that most of high school students who attend scouting activities consider they have a good and very good health. Following the results of Barbara Eigenschenk's study (2019) and her colleagues, along reducing illnesses, outdoor activities are associated with a good general subjective perception of health, which can also be noticed in the case of our research, even if they suffer from different illnesses, most of them consider they are in a good and very good health.

A third dependent variable of the research, school performances, was followed with the help of four questions. First of all, we wanted to find out which high schools the students, who participate at scouting activities, attend (Table 7.). We noticed that they attend the top graded high schools in the city.

Table 7. High schools where they study

\begin{tabular}{ll}
\hline The high school & Frequency \\
\hline National College „Al. Papiu” & 6 \\
National College Unirea & 7 \\
Economic College & 3
\end{tabular}

National Pedagogical College „Mihai Eminescu” 3

Art College

We asked the Explorers to tell us their final exam grade at the National Exam at the end of the $8^{\text {th }}$ grade.

Table 8 . The average at the National Exam at the $8^{\text {th }}$ grade

\begin{tabular}{cc}
\hline The average & National Exam $8^{\text {th }}$ grade \\
\hline 10 & $5 \%$ \\
$9,5-10$ & $50 \%$ \\
$9-9,5$ & $15 \%$ \\
$8,5-9$ & $25 \%$ \\
$8-8,5$ & $5 \%$
\end{tabular}

Taking into consideration the fact that the high schools they study at are good we expected the average to be good and indeed it was, $50 \%$ of the respondents had the average between 9,5 and 10 .

We also asked the average from the high school years and we made an average on each class. (Table 9.)

Table 9. The average for each class

\begin{tabular}{cc}
\hline Grade & The Explorers' average \\
\hline IX & 9,33 \\
X & 9,26 \\
XI & 9,41 \\
XII & 9,48
\end{tabular}

Analysing the data from these tables we noticed that if we added the Explorers' average in each class, individually, their average is more than 9 every time.

In order to highlight the fact that the activities made in their free time do not negatively affect school performances, but on the contrary they support and improve them, we asked the Explorers to specify the School Olympics they attended and the result they obtained.

Although our case study had only 21 respondents, the number of awards is impressive: at the international level a participation, at a national level 8 participations and awards obtained, and at the county and local level, in addition to those that brought national participation, 4 participations. We enumerate the extra-schooling results obtained at a national level:

- The German National Olympics $\left(2^{\text {nd }}\right.$ place $)+$ 
The German International Olympics

- The Biology National Olympics (Mention) place)

- The Geography National Olympics $\left(2^{\text {nd }}\right.$

- The Informatics National Olympics $\left(2^{\text {nd }}\right.$ and $3^{\text {rd }}$ places)

- The English National Olympics $\left(1^{\text {st }}\right.$ place $)$

- The Natural Sciences National Olympics (Mention)

- The Young People Debate National Olympics (Mention)

- The „Ars Nova” National Olympics (Mention)

Other studies that followed the benefits of outdoor activities highlighted an increase of the motivation for study, a higher involvement within the lessons, a higher academic learning, better efficiency and better results. More than this, it was shown that being active in the natural environment influences not only the attitude towards learning, but it also has effects upon the cognitive aspects, such as: attention, memory and the abilities to solve problems. (Eigenschenk, B., 2019).

\section{Discussions}

Being a case study and not a psycho-pedagogical experiment, there can be many variables that influence our results, but the information we obtained, corroborated with the ones offered by the specialised literature strengthen our believes.

The results obtained, reported to the hypothesis confirm our expectations. It was shown that the participation to the scouting activities contributes to the maintaining of well-being and high school students' health, we also notice that their school performance is a good one.

\section{Conclusions}

The influence of the scouting activities upon the variables followed turned out to be a positive one. It is true that scouting helps the young people to maintain their wellbeing and health. Also, their participation to non-formal activities did not distract their attention from studying, on the contrary, we can say that it maintained their school performances, maybe even improved it.
We would like, in the near future to make a bigger research, based on a psycho-pedagogical experiment, on a higher sample of students, and the independent variable to be introduced by us, having the possibility to control it better. More to the point, the study presented in this article is a motivation for a future research in the introduction of free time packages meant for high school students, that the teachers will be able to easily use, being designed to the smallest detail.

\section{Acknowledgments}

This work was possible with the financial support of the Operational Programme Human Capital 20142020, under the project number POCU 123793 with the title „Researcher, future entrepreneur - New Generation".

\section{Authors note:}

Veronica - Oana Irimia is an associate lecturer at the Department of Educational Sciences, Faculty of Psychology and Educational Sciences, Babeş-Bolyai University, Romania and a high school teacher at the "Mihai Eminescu" National Pedagogical College (Colegiul Național Pedagogic „Mihai Eminescu”) Târgu Mureș. Her Ph.D. is in Educational Sciences. Her research is in the field of non-formal education, extracurricular activities and scouts' activities.

\section{Appendix}

Questionnaire for the Explorers

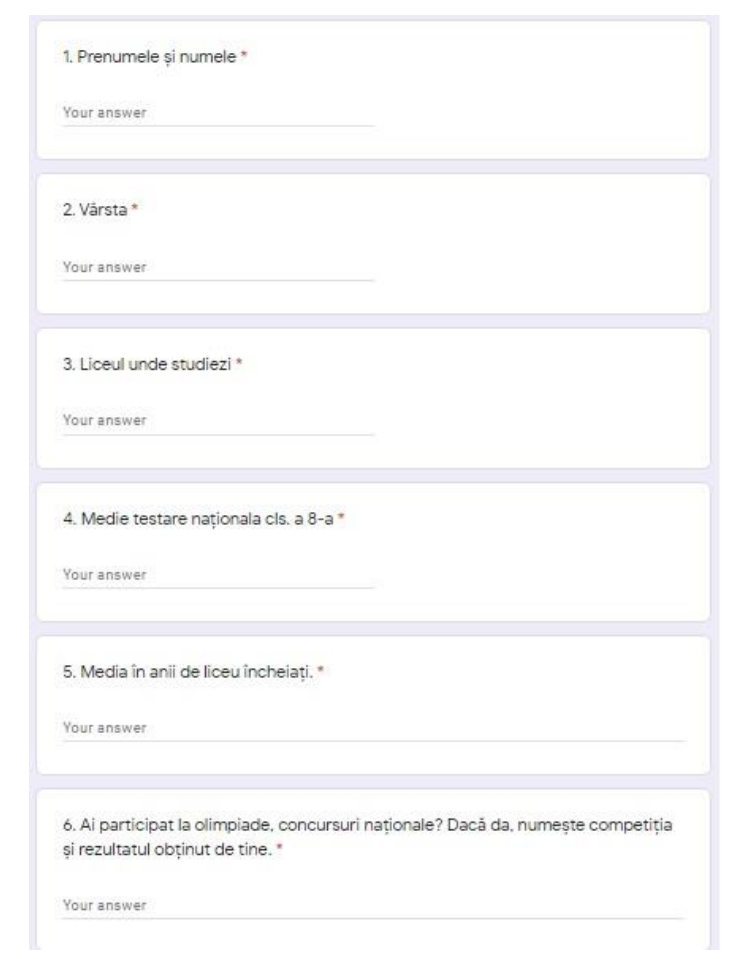



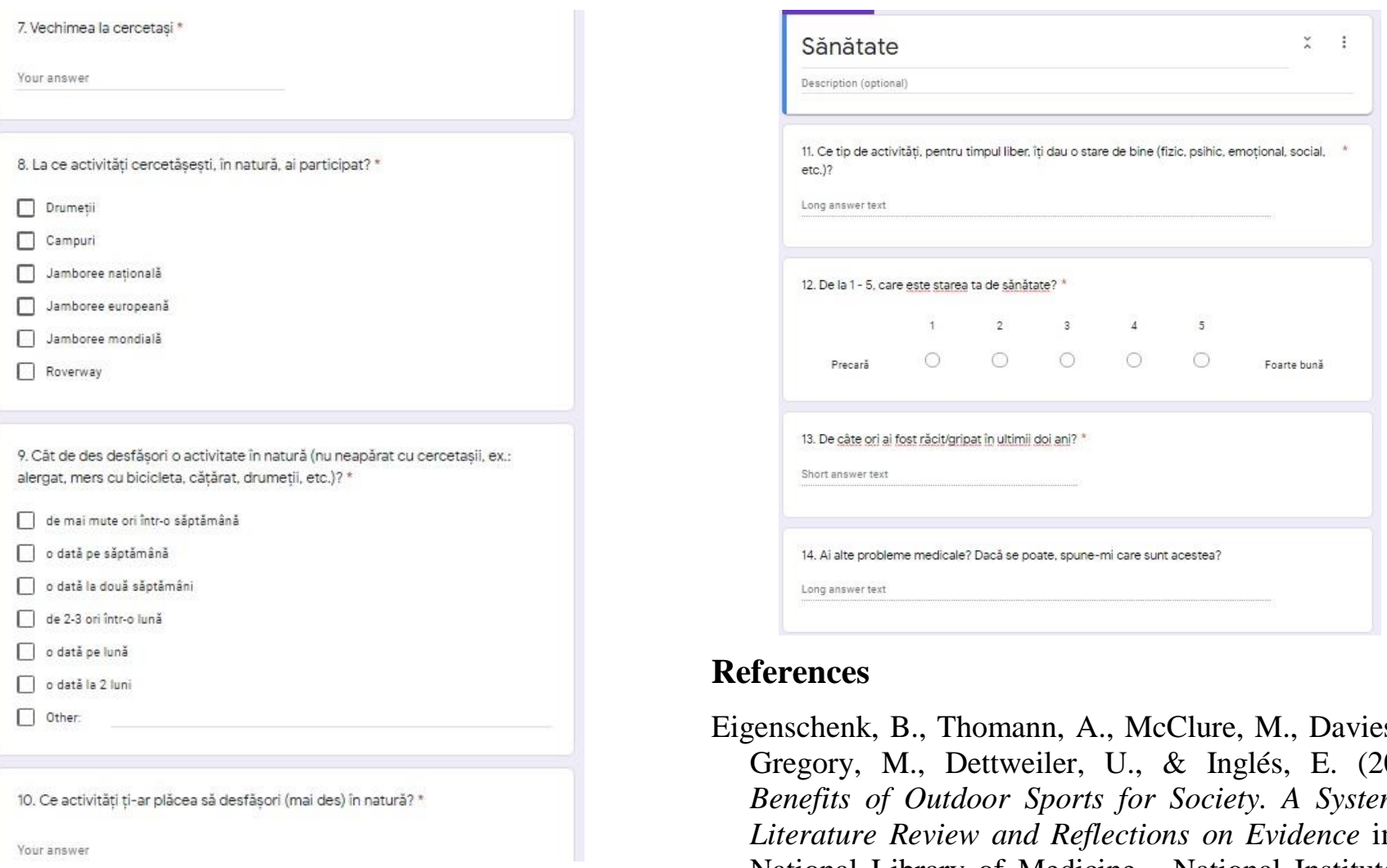

\section{References}

Eigenschenk, B., Thomann, A., McClure, M., Davies, L., Gregory, M., Dettweiler, U., \& Inglés, E. (2019). Benefits of Outdoor Sports for Society. A Systematic Literature Review and Reflections on Evidence in US National Library of Medicine - National Institutes of Health - Int J Environ Res Public Health, 2019 Mar; 16(6): 937.9 Available at: https://www.ncbi.nlm.nih.gov/pmc/articles/PMC64664 $42 /$

Moldovan, V.O. (2017), PhD Thesis: The influence of the non-formal education upon the young student's behaviour in formal educational contexts. Babes-Bolyai University. Cluj-Napoca.

www.cdep.ro/pls/legis/legis_pck.htp_act?ida=10408 (accessed at 20.02.2021).

www.isjdb.ro/static/files/Anexa_la_Ordin_4496_MECS.pdf (accessed at 19.02.2021).

www.scout.ro (accessed at 20.02.2021).

www.scout.org (accessed at 20.02.2021). 


\section{Aspects that could be Enhanced during the Initial and Continuous Training of the Primary School Teachers from Romania}

Nicoleta-Eugenia Meseșan, Diana-Crina Marin 


\title{
Aspects that could be Enhanced during the Initial and Continuous Training of the Primary School Teachers from Romania
}

\author{
Nicoleta-Eugenia Meseșan ${ }^{a *}$, Diana-Crina Marin ${ }^{b}$ \\ ${ }^{a, b}$ Doctoral School "Education, Reflection, Development”, Babes-Bolyai University Cluj-Napoca, 7 Sindicatelor Street, 400029, Romania \\ *Corresponding author: nicoletamese@yahoo.com
}

\section{Abstract}

Keywords:

professional competencies of the teachers; initial and continuous training; educational partnership; efficient strategies; beginner teachers.
Effective cooperation between parents and teachers has a huge effect on children's harmonious development. This study was conducted in order to establish the interests and the training needs of the teachers who are at the beginning of their careers. Recent studies have shown that children's positive school performances are strongly related to a high degree of family involvement in their education. The study has revealed that at the beginning of their teaching career some teachers felt vulnerable in the relationship with the parents. Also, some of them have lived negative experiences in the process of building an authentic partnership between the school and the families. The study has revealed that more attention should be given to pedagogical practice by creating contexts through which the future teachers organize and assist at activities with the parents. At the same time, the legislative framework regarding the activities of the mentors should be improved.

\section{Zusammenfasung}

\section{Schlüsselworte:}

Berufliche Kompetenzen der Lehrer; Aus- und Weiterbildung; Bildungspartnerschaft; effiziente Strategien; angehende Lehrer.
Eine effektive Zusammenarbeit zwischen Eltern und Lehrern hat einen großen Einfluss auf die harmonische Entwicklung der Kinder. Diese Studie wurde durchgeführt, um die Interessen und den Ausbildungsbedarf der Lehrer, die am Anfang ihrer Karriere sind, zu ermitteln. Aktuelle Studien haben gezeigt, dass die positiven schulischen Leistungen von Kindern stark mit einem hohen Maß an Familienbeteiligung in ihrer Erziehung zusammenhängen. Die Studie hat ergeben, dass sich einige Lehrer zu Beginn ihrer Lehrerkarriere in der Beziehung zu den Eltern verletzlich fühlten. Außerdem haben einige von ihnen negative Erfahrungen im Prozess des Aufbaus einer authentischen Partnerschaft zwischen der Schule und den Familien gemacht. Die Studie hat gezeigt, dass der pädagogischen Praxis mehr Aufmerksamkeit gewidmet werden sollte, durch die Einführung von Situationen, durch die die zukünftigen LehrerInnen Aktivitäten mit den Eltern organisieren und unterstützen. Gleichzeitig sollte der gesetzliche Rahmen bezüglich der Aktivitäten der Mentoren verbessert werden.

\section{Introduction}

Recent research studies have revealed that the didactic approaches through which each child is valued and systematically encouraged and studentcentered pedagogical practices are current trends with positive effects on pupils' school results and on the process of building effective partnerships between the school and the family. We believe that all persons who teach in primary education must know viable strategies to increase parental involvement in children's education and effective modalities to cooperate with parents. Generally, the abilities of communication, the level of their didactic competencies, empathy, and other personal qualities of teachers are associated with effective relationships with parents and other educational partners. We believe that the involvement of parents is an important way to support the academic achievement of students.
Positive relationships between parents and teachers are recognized as vital in this process of encouraging the student in order to obtain positive performances in the learning processes (Minke, et al, 2014).

\section{Theoretical foundation}

The degree of family involvement in children's education influences the level of pupils' motivation for learning, pupils' school results, and the degree of development of their multiple intelligences (Fantuzzo, McWayne, Perry, \& Childs, 2004; Fishel \& Ramirez, 2005; Izzo, Weissberg, Kasprow, \& Fendrich, 1999; Pavalache-Ilie \& Țîrdia, 2015).

The study conducted by Marin \& Bocos (2018) revealed that effective cooperation between school and families in order to optimize the learning of students in the family space is beneficial and contributes to the 
process of development of the children's multiple intelligences.

Also, the same study has revealed that the system used for evaluating the activity of teachers should also cover several aspects regarding the quality of cooperation between school and family (Marin \& Bocoș, 2018). Another study conducted in 2019 revealed that, in the opinion of school principals, the results of recent research on the process of strengthening the school-family partnership should be frequently disseminated and discussed by teachers during their meetings. Also, school principals are aware of the importance of building an effective partnership between school and family, agreeing that a high involvement of the family in school life has positive effects on the cooperation between parents and teachers. Recent studies have shown that organizing educational workshops for parents and students and extracurricular activities could positively influence the quality of the cooperation between parents and students (Marin \& Bocoș, 2018; Marin \& Bocos, 2019).

The document "Building Federation of ParentTeacher Relationships" (2007) of the American Federation of Teachers, mentions that effective communication between school and parents is necessary and beneficial for all educational partners. Thus, parents:

- are informed about the learning strategies used during the school program,

- are receiving information about the pupils' performances, their school results and also about their son/daughter's learning needs,

- are feeling involved in their own children's education.

At the same time, teachers:

- are receiving information about children's learning at home;

- can better support students in the learning activities;

- have a better opinion on the importance of the school activities and so the children's and the teachers' motivation increases;

For pupils, a positive influence is highlighted in:

- $\quad$ increasing the school results;

- $\quad$ increasing the motivation for learning;
- improving the student's behaviour;

- generating positive attitudes towards school tasks and school in general.

The process of building effective school-family partnerships could be affected by various challenges and obstacles that are not related to the teacher's activity. Recent studies revealed that regular meetings and communication between parents and teachers are positive practices that could prevent conflicts and the differences of visions (Marin \& Bocoș, 2019). According to the results of this study, some of the obstacles frequently encountered are the socioeconomic status of the family, the inadequate intervention of some parents in the educational process, a low level of confidence between partners, and the long absence of some of the parents who work in other countries.

\section{Research methodology}

The issue of the parent-school relationship is an essential topic, considering the positive influences of their continuous cooperation on the efficiency of the instructive-educational activity. Understanding the importance of the issue of school-family cooperation, we have decided to follow this aspect of the teaching activity by conducting a survey. The questionnaire created by us contains seven questions (see Annex 1). Five of the questions allow the selection of multiple variants of response, while two of them are openended questions. The questions were created to collect information about the teachers' experiences related to the relationships with parents. Also, recommendations for beginning teachers were formulated.

\section{Results}

The distribution of the respondents in the research group is the following: 50 teachers, with different teaching experience, who work in both urban and rural areas. Thus, the distribution of the group of respondents, considering their work seniority, is the following: between $0-2$ years ( $18 \%$ of the respondents, i.e. 9 people), $2-5$ years ( $16 \%$ of the respondents, i.e. 8 people), between $5-10$ years $(14 \%$ of the respondents, i.e. 7 people), and over 10 years (50\% of the respondents, i.e. 26 people). 
Figure 1. The description of the group of respondents, considering their work seniority

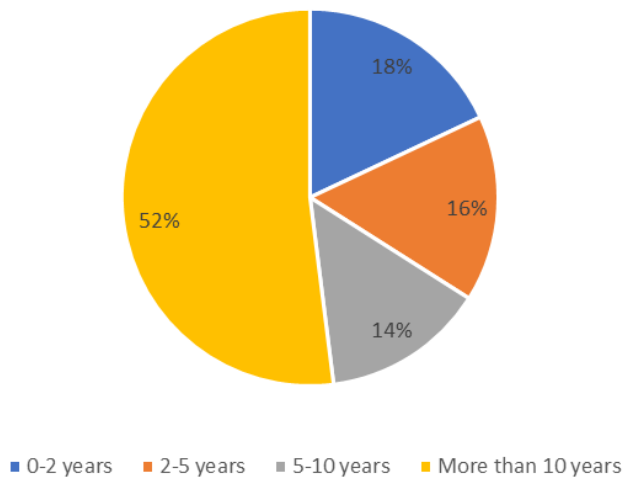

The teachers' group was composed of teachers with work seniority less than 10 years. They were selected considering that they have lived more recently the beginners' experiences so their needs are current and easily identifiable.

The questionnaire was applied in the online environment, using Google Docs applications, and for the quantitative interpretation of the data, the same application was used. The results will be presented below.

Thus, for the first question: "How was the first interaction with the parents of the students from your class, as a beginner?", $34 \%$ of the respondents (i.e. 17 teachers) stated that they felt very well, because they felt openness from on the parents' side, and 38\% (i.e. 24 teachers) among the respondents felt pleasant in their new role. This interaction was difficult and very difficult for $14 \%$ of teachers, and $1 \%$ do not remember (see Figure 2).

Figure 2. The perception of the teacher regarding the first interaction, as a beginner, with the parents

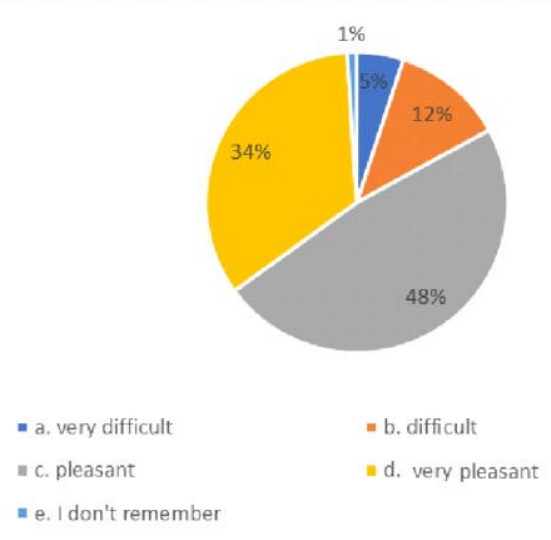

For the question "Do you consider that there were errors in your relationship with your parents?", $72 \%$ of the respondents (i.e. 36 teachers) considered that there were no errors, while and $28 \%$ of them (14 respondents) answered affirmatively (see Figure 3).

Figure 3. The opinions of the teachers regarding the possible errors that occurred during the process of constructing an effective partnership with parents

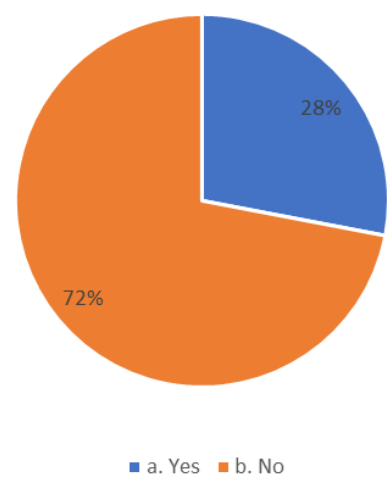

Through question no 3, we aimed to establish some difficult situations or mistakes that were made by the teacher in the relationship with the parents. Among the examples listed most often were: communication errors, lack of trust in a beginner, lack of feedback, lack of empathy from the teacher, too much distance or closeness in the relations with parents, difficulties in communicating with parents whose children had behavioural problems, lack of firmness on the part of the teacher.

Question 4 has the purpose to establish the efficiency of the initial training of the teachers; in the field of the school-family partnership. Most respondents ( $64 \%$ of the respondents, i.e. 36 teachers) stated that they were very well prepared or well prepared, but $26 \%$ of them were poorly prepared to interact with parents (i.e. 13 respondents). $6 \%$ of the respondents felt unprepared for their first interactions with the parents (3 teachers) (see Figure 5).

Figure 5. The opinions of the respondents regarding the efficiency of their initial training

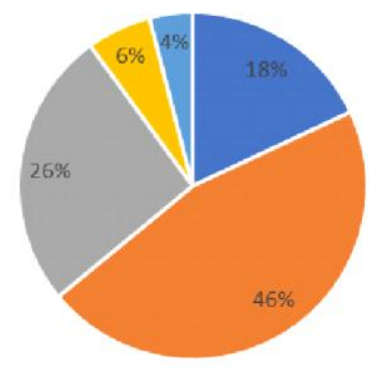

\footnotetext{
- a. very well prepared $\|$ b. relatively prepared $\|$ c. poorly prepared

॥ d. unprepared = e. Idon't remember
} 
The beginning teachers have received support from a colleague regarding the process of consolidating the partnership with the families, in 50\% of the respondents (i.e. 25 teachers). The mentor established by the school or the school management offered support for $10 \%$ of respondents (i.e. 5 teachers). $28 \%$ of the respondents, respectively 14 teachers, stated that they did not receive any help (see Figure 6).

Figure 6. Persons who offered assistance to the beginning teachers
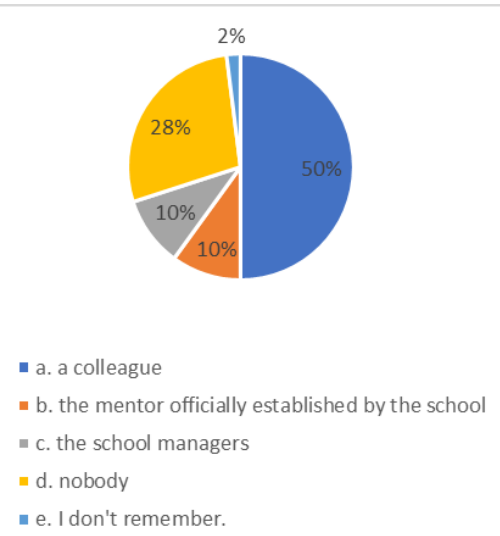

In order to increase the quality of training in the field of the optimal management of the relationships with parents, respondents have recommended that during the initial training future teachers should carry out various specific activities. Thus, the simulation of meetings/meetings with parents is the solution proposed by $70 \%$ of the respondents (i.e. 35 teachers), organizing practical activities, conducted in application schools, in collaboration with students' families are proposed by $58 \%$ of the respondents (29 persons), and more time specially allocated for theoretical training in the field of school-family partnership is the option proposed by $34 \%$ of the teachers who filled in the questionnaire, respectively 17 persons (see Figure 7).

Figure 7. Proposals for improving the initial training of future teachers

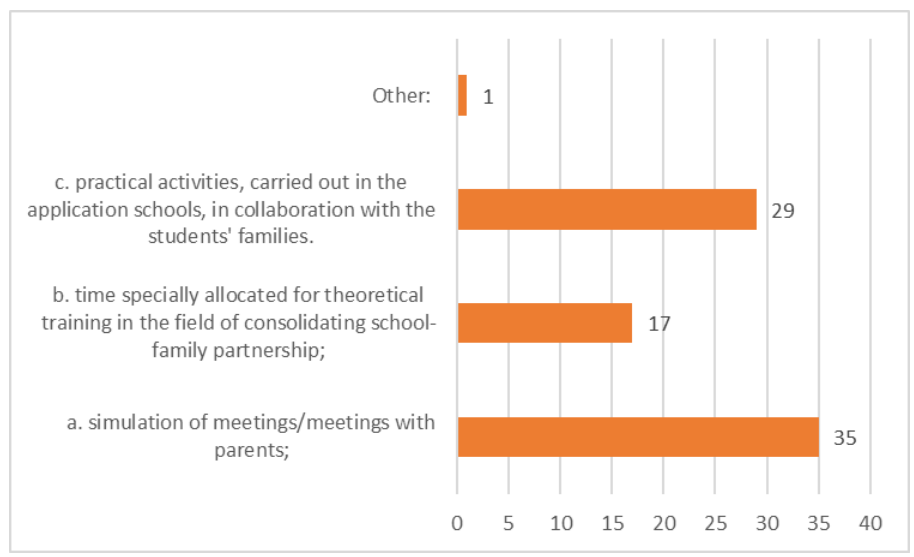

Through question no 7, respondents were asked to provide advice to beginning teachers in order to maintain a good relationship with the parents of their students. The advice offered was numerous and diverse. The respondents recommended: good professional training, assertive communication, the manifestation of empathy, calm tone, respect for parents, self-confidence, but without irony and superiority, and active listening. Some of the recommendations were related to a permanent collaboration with more experienced colleagues, but also with the school manager, who can be a good mentor, being able to support the beginning teacher in building an effective collaboration and communication relationship with each parent.

By analysing the obtained results, we can affirm that most of the respondents considered that it was easy to establish a collaborative relationship with the parents, and their attributions were facilitated even by the parents, in some cases. In general, the beginning of their career was pleasant, enjoyable, interesting. Only a small part of the respondents encountered difficulties in collaborating with the students' families, which is not surprising because the multitude of tasks assigned to a beginner teacher can be overwhelming, and establishing relationships with people of different ages, roles and functions can generate a constant pressure. It is gratifying that in most cases, parents have facilitated the school-family collaboration, offering support, respect, and trust to the teacher.

It is also noteworthy that very few respondents say that they made mistakes in the relationship with the parents of their students. This attitude can be generated both by the high level of the quality of the initial training and by the support offered by colleagues, mentors, or school management for a correct and efficient start in this field of the teacher's activity.

According to the answers offered by the respondents, the support offered to beginners in the field of school collaboration with the family, was generally provided by colleagues. Mentors from the school or from other schools, in exceptional situations, are the ones who should take care of the beginner's activity in all areas of activity, including the relationship with the pupils' families. But, after analysing the collected answers, mentors were mentioned by only $10 \%$ of the respondents, as resource persons for beginning teachers. One argument could be that the mentoring activity is not well defined in the actual legislative framework, 
which creates deficiencies in their activity. Another argument would be that a novice teacher may more easily establish professional relationships with a colleague that he feels closer to, and not with an officially designated person.

\section{Discussions}

According to the respondents' responses, some of the beginning teachers have not received sufficient support in this area of their activity. This fact is worrying and could lead to difficult situations, generating anxiety or even conflictual relationships with parents. We believe that both the mentor and the schools' managers should help the beginning teachers, in order to have an efficient and coherent activity, not only to offer them support when conflictual situations occur. We believe that a coherent approach and adequate guidance will prevent the number of conflict situations or of dysfunctional relationships between the teachers and the students' families. Of course, this would increase the beginner teacher's self-confidence and could give credibility to his actions from the parent's perspective.

The main limit of this investigation is related to the short number of participants. Collaboration with parents is an important area of the activity of each teacher. We consider that the professional development of teachers in the direction of family counselling is important and beneficial. A high degree of empathy, positive attitudes toward parents and towards the teachers' activity and usually sending encouraging messages for parents and students should decrease the occurrence of conflictual situations and defensive attitudes of educational partners. If teachers and the school staff adopt frequently welcoming and friendly attitudes, the school environment will become more attractive and accessible for parents.

\section{Conclusions}

In conclusion, this present research highlights some important aspects regarding the activity of the primary school teachers:

- collaboration with students' families is an important segment of the teaching activity;

- the abilities to manage in an effective way school-family relationship are very important for all teachers;

- it is necessary to identify optimal strategies to enhance the involvement and the collaboration of the school with the family;
- the training of teachers for collaboration with students' families must be done both in the initial training stage and in later stages;

- the beginning teacher must show an increased interest in developing this dimension of professional competence, but must also to benefit from the support and guidance from both mentors and the school management.

The fact that many of the respondents did not receive support and did not make mistakes in the process of building the school-family partnership, leads us to the idea of very good training in this field in the initial training stage. Even if they did not have negative experiences in this field, all the respondents believed that more attention should be given to the strategies used in the initial training of the teachers. We can conclude that during the initial training of the teachers more attention should be given to the practical approaches to this field, not only to the theoretical information. During the stage of pedagogical practice, the teachers-mentors should create opportunities for beginning teachers to interact with the parents. In this way, the competencies which are necessary for this sector of their didactic activity will be formed from a practical perspective, not just from a theoretical approach. We consider the organization of simulations of meetings with parents or even the participation in meetings organized with parents of the students to be very useful. At the same time, we are aware that, unfortunately, the future teachers' involvement in the activities with the parents is not always accepted or encouraged and the future teachers are extremely rarely involved in this type of activity. The reasons can be various, such as the possible restraints imposed by the parents regarding the participation of an unknown person during the activities, the insecurity of the teacher in the relationship with the parents, the legislative framework regarding the protection of students' data, etc.

\section{Acknowledgments}

We would like to thank all the participants for their support in conducting this study.

Authors note: The authors have equal contributions to this article.

Nicoleta-Eugenia Meseșan is currently a pedagogy teacher at "Gheorghe Lazăr" Pedagogical National College, in Cluj-Napoca and a collaborator of Babeș-Bolyai University. She is a researcher interested in finding the best strategies that could be 
used in order to optimize the initial and continuous training of teachers. In 2020, she obtained a Ph.D. in Educational Sciences, from the Babeș-Bolyai University.

Diana-Crina Marin is currently a teacher at "Pavel Dan" Theoretical High School, in Câmpia Turzii and a postdoctoral researcher at the BabeșBolyai University. Her research areas are aimed to find innovative modalities to consolidate the school-family partnership, considering that the school and family should be real partners regarding the children's education. She is also interested in finding the most effective teaching practices that could be successfully used in the educational process.

\section{Appendix A.}

\section{Questionnaire regarding the teacher-parent relationship}

\section{Dear Colleagues,}

The questionnaire below was designed in order to establish the training needs of the teachers in the field of consolidating the school-family partnership. By answering these questions, you will help us to identify some problems and will propose optimal solutions together. Thank you for your availability!

1. How was the first interaction, as a beginner, with the parents of the students from your class?

a. very difficult

b. difficult

c. pleasant

d. very pleasant, because felt parents' openness and their availability to cooperate

e. I don't remember

2. Do you consider that there were errors in your relationship with the parents?
a. Yes
b. No

3. If you answered "Yes" to the above question, give 1-2 examples.

4. Did you feel ready at the beginning of your career to interact with the parents of your students?

a. very well prepared

b. relatively prepared
c. poorly prepared
d. unprepared
e. I don't remember

5. In your relationship with the parents, you have received support from:

a. a colleague

b. the mentor officially established by the school

c. the school managers

d. nobody

e. I don't remember.

6. In order to optimize the training of the future teachers in the field of school-family partnership, the following should be organized during the initial training:

a. simulation of meetings/meetings with parents;

b. time specially allocated for theoretical training in the field of consolidating school-family partnership;

c. practical activities, carried out in the application schools, in collaboration with the students' families.

Other:

7. Write down some recommendations for teachers at the beginning of their career regarding the relationship with parents.

8. Seniority as a teacher:

a. 0 -2 years

b. 2-5 years

c. 5-10 years

d. In 10 years

Thank you for your time!

\section{References}

American Federation of Teachers, (2007). Building ParentTeacher Relationships. Washington, D.C.: American Federation of Teachers.

Fantuzzo, J., McWayne, C., Perry, M. A., \& Childs, S. (2004). Multiple dimensions of family involvement and their relations to behavioral and learning competencies for urban, low-income children. School Psychology Review, 33(4), 467-480. doi: https://doi.org/10.1080/02796015.2004.12086262

Fishel, M., \& Ramirez, L. (2005). Evidence-based parent involvement interventions with school-aged children. 
School Psychology Quarterly, 20, 371-402. doi: https://doi.org/10.1521/scpq.2005.20.4.371

Izzo, C. V., Weissberg, R. P., Kasprow, W. J., \& Fendrich, M. (1999). A longitudinal assessment of teacher perceptions of parental involvement in children's education and school performance. American Journal of Community Psychology, 27, 817-839. doi: 10.1023/a:1022262625984. PMID: 10723536

Marin, D.-C., \& Bocoș, M. (2018, in press). The Effects of a High Family Involvement in Pupils' Education. Manuscript submitted for publication.

Marin, D.-C., \& Bocoș, M. (2019). School Principals' Opinion on the Strategies of Strengthening SchoolFamily Partnership, The European Proceedings of
Social \& Behavioural Sciences EpSBS, LXIII, 544-550. doi: https://doi.org/10.15405/epsbs.2019.06.64.

Minke, K. M., Sheridan, S. M., Kim, E. M., Ryoo, Ji H., \& Koziol, N. A. (2014). Congruence In Parent-Teacher Relationships, Faculty Publications from CYFS. The Elementary School Journal. 114(4), 526-546. Retrieved from:

https://digitalcommons.unl.edu/cgi/viewcontent.cgi?art icle $=1098 \&$ context $=$ cyfsfacpub

Pavalache-Ilie, M., \& Țîrdia, F.-A. (2015). Parental Involvement and Intrinsic Motivation with Primary School Students. Procedia - Social and Behavioral Sciences, $\quad$ 187, 607-612. doi: https://doi.org/10.1016/j.sbspro.2015.03.113 


\section{Experimental Program For School Integration Of} Re-Migrant Middle School Students With Learning Difficulties In Romanian Language And Literature

Rafila-Elisabeta Ilovan 


\title{
Experimental Program For School Integration Of Re-Migrant Middle School Students With Learning Difficulties In Romanian Language And Literature
}

\author{
Rafila-Elisabeta Ilovan ${ }^{{ }^{*}}$
}

${ }^{a}$ Doctoral School Educational, Reflection, Development, Babes-Bolyai University, 7 Sindicatelor Street, 400029, Cluj-Napoca, Romania

*Corresponding author: rafy_tupcil92@yahoo.com

\section{Abstract}

Keywords:

learning difficulties; integration; migration; remigration; Romanian language and literature; vocabulary; syntax; text comprehension; performance.
In contemporary society, the phenomena of territorial mobility / geographical mobility - migration (internal or external) and return migration / remigration (determined or forced), phenomena determined by various social and economic factors, are significantly accentuated. These complex and sensitive phenomena are increasingly attracting the interest of researchers and are often investigated in a multi- and interdisciplinary manner, with various implications: demographic, sociological, psychological, educational, axiological etc. From an educational perspective, external migration and return migration / family migration can have a major impact on children and various influences, which can be analyzed in formal, non-formal and informal contexts. The study approaches in formal educational contexts, a topic less explored in the literature, although it springs from the current educational reality. The analyzed issue was inspired by the didactic experience, as well as by the common interest of the professional community of teachers and of the scientific community for identifying and removing the difficulties encountered by re-migrant students in the Romanian educational system.

\section{Zusammenfasung}

\section{Schlüsselworte:}

Lernschwierigkeiten; Integration; Migration;

Rückwanderung; Rumänische

Sprache und Literatur;

Wortschatz; Syntax;

Textverständnis; Performance
In der heutigen Gesellschaft werden die Phänomene der territorialen Mobilität / geografischen Mobilität - Migration (intern oder extern) und Rückwanderung / Remigration (bestimmt oder erzwungen), Phänomene, die durch verschiedene soziale und wirtschaftliche Faktoren bestimmt werden, erheblich akzentuiert. Diese komplexen und sensiblen Phänomene ziehen zunehmend das Interesse von Forschern auf sich und werden häufig multi- und interdisziplinär untersucht, mit verschiedenen Auswirkungen: demografisch, soziologisch, psychologisch, pädagogisch, axiologisch usw. Aus pädagogischer Sicht externe Migration und Rückwanderung / Familienmigration kann einen großen Einfluss auf Kinder und verschiedene Einflüsse haben, die in formellen, nicht formalen und informellen Kontexten analysiert werden können. Die Studie befasst sich mit formalen Bildungskontexten, ein Thema, das in der Literatur weniger erforscht ist, obwohl es aus der aktuellen Bildungsrealität stammt. Das analysierte Thema wurde von der didaktischen Erfahrung sowie vom gemeinsamen Interesse der Berufsgemeinschaft der Lehrer und der wissenschaftlichen Gemeinschaft inspiriert, die Schwierigkeiten zu identifizieren und zu beseitigen, auf die Schüler mit Migrationshintergrund im rumänischen Bildungssystem stoßen.

\section{Introduction}

Every year, hundreds of Romanian families decide to go abroad, in order to find a better job. A large part of them took their children with them, to prevent some traumas among the little ones or to keep them in parental care. Due to the economic crisis or family problems, a large number of families who have gone abroad, return to the country. Once back, middle school students face great difficulties in learning and accommodation, because they think in another language and in most cases, students communicate more correctly in the language of the country where they grew up than in Romanian. A large part of the number of re-migrant students never had contact with the Romanian school, being born abroad. They have almost no command of the Romanian language, they have faced a different linguistic context. For remigrant students, the Romanian school is difficult to access.

\section{Theoretical foundation}

In the literature are specified different definitions of the concept of learning difficulties, designed from different perspectives, depending on which the concept was investigated. It cannot be said that a general definition has been reached, because this concept is complex and as the definitions are formulated at the moment, the variants only partially cover the investigated reality. 
Praxiological Dictionary of Pedagogy. Volume I: A-D (Bocoș (coord.), Răduț-Taciu, Stan, 2016, p. 339) gives us a clear and complex definition of the term learning difficulty. Thus, in a broad pedagogical/educational sense, the term refers to a set of obstacles, as well as moments of oscillation, which materialize in a set of particular manifestations, involved in the development of the personality of an individual who is involved in a continuous process for studying. In a narrow pedagogical/educational sense, learning difficulties are correlated with a faulty, weak or deficient organization of the approaches and learning activity performed by students, an organization that can have negative consequences on: acquisition - perception and reception, organization, retention, comprehension/understanding, processing/processing of information (verbal and nonverbal), rendering, expressing, transmitting/communicating them.

From the etymological point of view, the word "integra" comes from the Latin integro, integration and integration, integrationis, used with the meaning to renew, complete. The handiest definition is given by the Explanatory Dictionary of the Romanian Language (Academia Română, Institutul de Lingvistică „Iorgu Iordan”), thus, the integration is presented as "1. Inclusion in a collective; 2. Incorporation into a whole."

Ghergut (2006, p. 17) argues that integration involves "placing or transferring a person from a more or less segregated environment to an ordinary one, aiming at the set of measures that apply to various categories of the population, and seeks to remove the separation in all its forms (the term segregation is relative and can be applied to all children and individuals, as well as to all aspects of human life)".

Assimilation was seen as a process in which "immigrants were incorporated into society through a unique process of adaptation" (Castles et al., 2009, p. 247). Since assimilation, the concept of multiculturalism has gained popularity, which encourages migrants to preserve their cultural identities. Integration was understood as a two-way process that requires adaptation from the migrant, but also from the host society (Castles et al., 2003).

In Romania, there are legislative projects that highlight the importance of maintaining students with learning difficulties in the educational system, as well as the importance of supporting them in the process of their training and development. However, the reality shows that, often, the two concepts are confused, both in theoretical approaches and in school practice, as well as that integration is difficult to achieve, being hindered by objective and subjective factors.

Structural integration has become a priority in Romania, but in the Romanian schools there is a need for more openness (from individuals, groups, communities, institutions, educational and social agents etc.) and acceptance for the process of social, cultural and identifying integration, because there are still trends and cases of marginalization and segregation, especially in the school space, but also in the social one.

At present, in Romania there are two education systems: the mass education system - consisting of students with learning difficulties and the special education system, in which there are students with disabilities. However, it is found that learning difficulties are confused with disabilities, fact that affects educational and curricular practices. Also, it is detected the existence of the phenomenon of segregation, in the sense that students with learning difficulties are marginalized and are considered a problematic category. In fact, students with learning difficulties need to be supported to manage and overcome them, using appropriate teaching tools.

The term "migration" has been defined by several authors, for instance Sandu (1994) defined migration as "an essential component of development processes. The different forms of this phenomenon are correlated with economic changes, social structure and quality of life. Under certain conditions and certain aspects, migration appears as a reaction to these changes; in turn, that reaction can have effects in the areas of economic life, quality of life and social structure" (p. 9).

In the case of voluntary migration, reintegration can be defined as "a process that enables the returnee to participate again in the social, cultural, economic and political life of his or her country of origin." (Cassarino, 2008, p. 13)

Regarding remigration, the study shows that some cases are known as voluntary return, others as forced remigration. Framing in one situation or another depends on the European context, the needs and the profile of migrant families. Although traumatic factors are definitely a high risk for migrants, there are also beneficial factors reflected in school performance, such as the foreign language that the student speaks 
and which gives him self-confidence and a state of constructive independence.

\section{Research methodology}

The purpose of this research was to verify whether the elaboration of a program for re-migrant students has valences in the direction of identifying and removing learning difficulties in the Romanian language and literature of students and in the direction of improving their school integration.

The experimental approach aims to verify the following hypothesis:

Participation of migrant middle school students in an experimental school integration program, composed from intervention modules focused on identifying and early removal of learning difficulties in Romanian language and literature, will significantly contribute to the development of skills in understanding texts, using vocabulary, using of syntax and will increase the pace of school integration.

The research variables are the following:

\section{Independent variable:}

- Participation of re-migrant middle school students in an experimental school integration program;

\section{Dependent variables:}

- $\quad$ The level of vocabulary skills development of re-migrant students;

- The level of understanding of a text in Romanian for re-migrant students;

- The level of development of the syntax skills;

- The level of school performance in the Romanian language and literature tests of re-migrant students;

- The pace of school integration of re-migrant students

In our practical-applicative approaches we have used the following complementary:

- $\quad$ methods of pedagogical research: psychopedagogical experiment, method of systematic observation, method of investigation, method of focus group, method of tests, method of case study, method of analysis of products of students' activity, method of researching school documents;
- $\quad$ pedagogical research tools: questionnaire, interview guide, text comprehension test, vocabulary test, syntax test, observation grid, school progress record sheet, scale - Sense of Community Index II.

The research initiated by us targeted two important categories of subjects, directly involved in the educational process: students and teachers. Therefore, the sample of subjects was made up of Romanian language teachers from Bistriţa-Năsăud County and middle school students returning from abroad.

- Teachers of Romanian language and literature - we selected a number of 180 teachers from Bistrița-Năsăud County, teachers of Romanian Language and Literature at middle school level, who faced such situations and declared themselves willing to participate in a study on this theme.

- $\quad$ Middle school students, re-migrants - 124 students from $5^{\text {th }}-8^{\text {th }}$ grades, from Bistrița-Năsăud County were selected in the sample. They were included in an experimental program for the prevention and solution of learning difficulties encountered in the Romanian language and literature discipline.

Regarding the sample of content, we identified the topics and contents that were included in the experimental program in accordance with the school curriculum in the Romanian Language and Literature discipline. The experimental program developed and implemented by us during the 8 months of the 20182019 school year focused on 10 teaching activities. The activities took place systematically, one activity per week.

\section{Results}

Analysis of the results of the initial test and establishment of the difficulties faced by re-migrant students

The analysis of the results obtained by the remigrant middle school students, at the initial testing of the Romanian language and literature discipline allowed us to present the problems they face. Thus, we found the following main difficulties:

- difficulties in understanding a text at first sight;

- $\quad$ reduced vocabulary;

- difficulties in identifying 
- confusions of meanings;

- $\quad$ phonetic confusions;

- difficulties in constructing sentences and phrases;

- difficulties in dividing words into syllables;

- morphological difficulties (non-recognition of speech parts);

- difficulties in interpreting a sequence from the text;

- difficulties in writing a text, with a given theme, not respecting the specific structure;

- $\quad$ spelling and punctuation errors;

- $\quad$ excessive use of foreign words in Romanian language;

- $\quad$ expression difficulties (inadequate expression of ideas).

At the same time, the analysis of the initial test results shows that there is a predominance of problems such as: difficulties in understanding texts, difficulties in identifying synonyms and antonyms, morphological/syntactic difficulties, difficulties in constructing sentences and phrases and the frequency of spelling and punctuation errors. Also, students showed a low level in the assessment of verbal skills (re-migrant students presented a reduced vocabulary and difficulties in understanding the texts in Romanian).

The experimental school integration program was applied, consisting of intervention modules focused on identifying and early removal of learning difficulties in Romanian language and literature, through which we aim to contribute to ensuring school progress and intensifying the pace of integration school. In performing this program, we considered the fact that the reduction of the difficulties specific to the discipline of Romanian language and literature presents a specific process, an aspect that determined us to elaborate it in three phases:

1) The initial phase - stage in which the teacher designs the teaching-learning sequences, based on gathered information regarding the specific difficulties of the Romanian language and literature;

2) Development phase - stage in which the teacher puts the student in appropriate situations in relation to the object of learning, with the learning difficulties they face and at the same time promotes cooperation relations and interactions such as student-student, student-teacher, student-other human sources.

3) Consolidation phase - phase in which the teacher analyzes the effects of applying the experimental school integration program.

To observe the changes produced by the participation of re-migrant students in our experimental program, we applied the posttest. We specify that there were no changes in the composition of the sample of subjects.

Figure 1. Grades obtained in the assessment test

\section{EVALUATION TEST RESULTS}

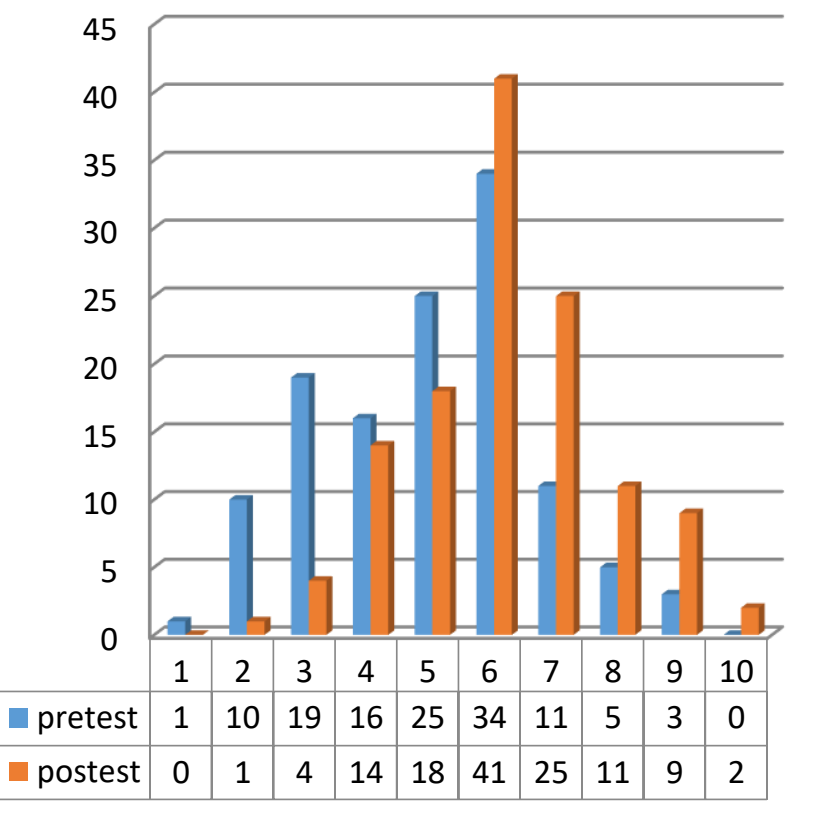

In figure no. 1 school progress is observed, by categories of marks obtained in the initial test and in the final test.

There is a significant numerical difference in the categories mark 7 (seven) and mark 8 (eight). Thus, we have the following situation:

- $\quad$ an increase from 11 marks to 25 marks of 7 (seven);

- $\quad$ an increase from 5 marks to 11 marks of 8 (eight);

- $\quad$ an increase from 3 marks to 9 marks of 9 (nine);

- 2 marks out of 10 (ten) were obtained. 


\section{Correlational study}

Table no. 1. The matrix of correlations between the dependent variables vocabulary, syntax, text comprehension, performance in the Romanian language assessment test and school integration of remigrant middle school students

Variables included in the study Vocabulary Syntax Comprehension of texts Performance on the assessment test School integration

\begin{tabular}{|c|c|c|c|c|c|}
\hline $\begin{array}{c}\text { Variables } \\
\text { included in the } \\
\text { study }\end{array}$ & $\begin{array}{l}\text { ปे } \\
\frac{0}{3} \\
\frac{0}{0} \\
\vdots\end{array}$ & 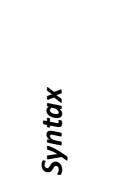 & 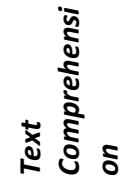 & 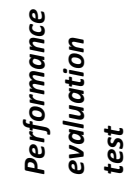 & 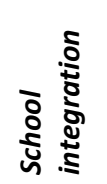 \\
\hline Vocabulary & 1 & $0.637^{* *}$ & $0.739^{* *}$ & $0.537^{* *}$ & 0.150 \\
\hline Syntax & $0.637^{* *}$ & 1 & $0.512^{* *}$ & $0.246^{* *}$ & $0,190^{*}$ \\
\hline $\begin{array}{l}\text { Text } \\
\text { Comprehension }\end{array}$ & $0.739^{* *}$ & $0.512^{* *}$ & 1 & $0.553^{* *}$ & $0.344^{* *}$ \\
\hline $\begin{array}{l}\text { Performance } \\
\text { evaluation test }\end{array}$ & $0.537^{* *}$ & $0.246^{* *}$ & $0.553^{* *}$ & 1 & 0.170 \\
\hline $\begin{array}{l}\text { School } \\
\text { integration }\end{array}$ & 0.150 & $0.190^{*}$ & $0.344^{* *}$ & 0.170 & 1 \\
\hline
\end{tabular}

**. The correlation is significant at the probability level of 0.01 .

*. The correlation is significant at the probability level of 0.05 .

There is a significant positive relationship between the vocabulary variable and the syntax variable $(\mathrm{r}=$ $0.637, \mathrm{DF}=122, \mathrm{p}<0.01)$.

There is a significant positive relationship between the vocabulary variable and the text comprehension variable $(r=0.739, \mathrm{DF}=122, \mathrm{p}<0.01)$.

There is a significant positive relationship between the vocabulary variable and the performance variable in the evaluation test $(\mathrm{r}=0.537, \mathrm{DF}=122, \mathrm{p}<0.01)$.

There is a significant positive relationship between the syntax variable and the text comprehension variable $(\mathrm{r}=0.512, \mathrm{DF}=122, \mathrm{p}<0.01)$.

There is a significant positive relationship between the syntax variable and the performance variable in the evaluation test $(r=0.246, \mathrm{DF}=122, \mathrm{p}<0.01)$.

There is a significant positive relationship between the syntax variable and the performance variable in the evaluation test $(r=0.246, D F=122, p<0.01)$.

There is a significant positive relationship between the syntax variable and school integration $(r=0.190$, $\mathrm{DF}=122, \mathrm{p}<0.05)$.
There is a significant positive relationship between the text comprehension variable and the school integration variable $(\mathrm{r}=0.344, \mathrm{DF}=122, \mathrm{p}<0.01)$.

There is a significant positive relationship between the syntax variable and the performance variable in the evaluation test $(r=0.246, \mathrm{DF}=122, \mathrm{p}<0.01)$.

There is a significant positive relationship between the text comprehension variable and the performance test variable $(\mathrm{r}=0.553, \mathrm{DF}=122, \mathrm{p}<0.01)$.

There were no significant correlations between the variables: vocabulary and school integration; performance test and school integration test.

\section{Conclusions}

In conclusion, we stated that the results obtained in the experimental research, in the case studies and in the correlational study confirm the research hypothesis. Thus, the participation of re-migrant middle school students in an experimental school integration program will significantly contribute to the development of skills in understanding texts, using vocabulary, correct use of syntax, ensuring school performance in Romanian language and literature tests and will increase the pace of school integration.

\section{Authors note:}

Rafila-Elisabeta Ilovan is currently a teacher at Mihai Eminescu School Năsăud, Bistrița-Năsăud County, Romania and doctoral student at BabeșBolyai University. Her fields of research aim to provide students information and support. She is also interested in finding the children's learning needs and giving them all the necessary resources.

\section{References}

Academia Română, Institutul de Lingvistică „Iorgu Iordan”. (2012). Dicționarul explicativ al limbii române. ediția a II-a revăzută și adăugită. București: Editura Univers Enciclopedic Gold.

Bocoș, M.-D. (coord.), Stan, C., Răduț-Taciu, R., \& Chiș O. (2016). Dicționar praxiologic de pedagogie. Volumul I: A-D. Pitești: Editura Paralela 45.

Cassarino, J. P. (Eds) (2008). Return Migrants to the Maghreb, Reintegration and Development Challenges. San Domenico di Fiesolo, Italy: European University. Institute (EUI), Robert Schuman Centre for Advanced Studies.

Castles, S. \& Miller, M.J. (2003). The age of migration. ( $3^{\text {rd }}$ edition). New York: Palgrave Macmillan.

Castles S. \& Miller, M.J. (2009). The Age of Migration: International Population Movements in the Modern World (4 ${ }^{\text {th }}$ edition). Basingstoke: Palgrave MacMillan 
Gherguţ, A. (2006). Psihopedagogia persoanelor cu cerinţe speciale. Iași: Editura Polirom.

Sandu, D. (1994). Migration in market and democracy transition: Migration intentions and behavior in Romania. Population Research and Policy Review. Cooperation with the Southern. 


\section{Between Fear and Confidence. The influence of Feedback on a Student's Self-Perceived Image}

Adina O. Câmpean, Horia Corcheș 


\title{
Between Fear and Confidence. The influence of Feedback on a Student's Self- Perceived Image
}

\author{
Adina O. Câmpean ${ }^{\mathrm{a}}$, Horia Corcheș ${ }^{\mathrm{b}}$ \\ ${ }^{a, b}$ Doctoral School “Education, Reflection, Development”, Babes-Bolyai University Cluj-Napoca, 7 Sindicatelor Street, 400029, Romania \\ *Corresponding author: adina.campean@gmail.com
}

\section{Abstract}

Keywords:

influence of positive feedback;

student's self-perceived image;

implications of fear in the teaching

process; role models; strategies for

applying positive feedback.

\section{Schlüsselworte:}

Einfluss von positivem

Feedback; vom Selbst

wahrgenommenem Image des

Schülers; Auswirkungen von

Angst auf den

Unterrichtsprozess; Vorbilder;

Strategien zur Anwendung von

positivem Feedback.

Through this article, we intend to analyse one of the tools by which we can influence the projection of a positive self-perceived image on primary school students.

Our aim is to emphasise the importance of a conscious implementation of positive feedback, in teaching activities, designed to increase student involvement, to stimulate increased self-esteem, confidence and positive self-image.

\section{Introduction}

Romanian history, of the last century, has been tumultuous, vibrant, and familiar, for a long time, like the history of other European countries. The education system has been an integral part of these changes.

During the communist regime, the education system aligned itself with the regime-specific policy changes, which could be described as based on fear and strict rules. We do not support the idea that rules are a negative element in general, but in the context of the past regime, they stipulated building a "new man", obedient to the party ideology, afraid to express his opinion and trained to expose those who do it. This perspective is highlighted in the Final Report of the Presidential Commission for the Analysis of the Communist Dictatorship, 2006.

The 1990s brought about a radical change in politics, which led to the adoption of policies to reform the education system. In 2011, with the new Education Law, no. 1/2011, a new educational ideal was proposed, highlighting the "free, integral and harmonious development of human individuality, in the formation of autonomous personality and in assuming a system of values that are necessary for personal fulfillment and development, for the development of entrepreneurship, for active citizen participation in society, for social inclusion and for employment on the labor market". This can be consulted on the page https://edu.ro/sites/default/files/_fi\%C8\%99iere/Legi slatie/2020/LEN_actualizata_octombrie_2020.pdf.

Ideally, as teachers, we want to promote not only educational content, but also to coordinate the 'harmonious development' of the student, by building 
mental models through which students can translate what they think they know into everyday reality (Bain, 2004).

Whilst analysing this educational ideal, we must keep in mind that students will make decisions freely, will be harmoniously developed, balanced, and will assume value systems. Starting with value systems, this change of educational ideal could not change overnight the opinion of some adult generations; this would be the reformation of an entire system of beliefs and mentalities. For example, the following concepts are widespread and unfortunately accepted by many of the parents of students attending school: "My parents beat me, but now I am grateful for it." Other collected statements that reflect the same vision are: "the child must know about fear", "where the parent gives, grows up", "I made you, I kill you", "the beating is broken from heaven" etc. These commonly share the manifestation of authority based on fear. Conversely, at the other end of the spectrum are parents who are extremely permissive and believe that setting rules for their children hinders their harmonious development.

Therefore, teachers must carefully select the method by which they will aim to achieve their goals, given the family and social context from which the child comes. By correctly choosing the method, students' behavior and their attitudes, specifically human, can be developed in a positive way (Bocoș, 2017).

\section{Implications of fear in the teaching process}

The above statements as my parents beat me, but now I am grateful for it", "the child must know about fear", "where the parent gives, grows up", are verbalized meanings of adults. They reflect only a temporary submission, but the effects of parental education, in an authoritarian system, projected at least partially on their children, will be reflected in the child's behavior in the long run. As educators, we must keep in mind, and point out to those who adopt such a conception, that a child who is subjected to a treatment governed by fear will develop an egocentric vision. They will not learn compassion, no matter how much one tends to believe that he could understand suffering. In reality, the stimulus to which the child has been subjected makes him resilient in this sense and the treatment becomes "usual" for him, because he is trained in fear or dread.

Children will not be more respectful, but more fearful. The mentioned statements belong to a generation of adults and represent an unhealthy vision of some parents, and maybe even of some teachers, reflected in the treatment of their own children or students.

This introjection, "my parents beat me, but now I am grateful for it" will reflect on those around them and on future generations of children. This vision can reveal parents with a low self-image, who project their goals, in a negative way, through their children (Baumeister et al., 1996).

From a temporal point of view, the thirty years since the change of regimes are not enough for a radical change of mentality. We must point out that the idea that such a mentality of the parent is synonymous with an open communication in the teacher-parent relationship, is false. That mentality is not a control mode of the student, a relationship on which we can build a bridge between us and students in case of a conflict. Control over a situation will not be achieved in this way, because effective communication is certainly not built on a foundation based on fear.

There are several widespread opinions among parents and teachers that the child should learn, even out of fear. This type of learning, which is based on this meaning, has at least one visible negative side. Any student who will learn being motivated by this feeling, against a background of a fear or idea of danger, will associate in the future, the learning context with a negative feeling. When the student experiences fear in the future, this feeling is reactivated. For example, we do not touch something hot, because in our emotional memory we have reactivated an unpleasant memory. The fear- or the fright- is a feeling that can activate certain mechanisms that do not allow us to create a favourable environment to act freely, to become creative, to help others, to develop certain personal aspects, to have open and reflective attitudes, etc. For example, if a bear runs after us in the woods, we will not contemplate nature, but our goal will be to eliminate the danger. We deduce that a child who learns out of fear aims to obtain results, generating an inexplicable disadvantage for him, because he did not develop creativity to the same extent as a child who learns with pleasure. In conclusion, the student will focus on avoiding negative consequences, not trying new things, a situation that will lead to capping, a false balance, and the assumption that failure is attributed to him. 
Why should we care about this facet? Not only because the student, who comes from the mentioned environment, knows in principle to communicate only this way, but because we will not succeed in fulfilling one of the facets of the educational ideal, "harmonious development necessary for personal fulfillment and development and active citizen participation". The failure will not be of the child, nor of the parent who was not guided, but of us, of the teachers, who were passive in front of these experiences.

\section{Positive feedback, is it a recipe for success?}

Feedback is a response based on a set of information about the student's performance related to a time of his school development and progress. Feedback is not a personal opinion offered by a teacher but reflects an equilibrium between action and reaction, providing a clear and common goal for all.

The Romanian language has specific politeness rigors, namely through the existence of politeness pronouns and verbal forms of the second person plural so that, in the social context, communication is done through the aforementioned filter; this being reflected, even in the educational environment, within the interaction and communication relations between student and teacher. Regardless of age, due to the aforementioned contexts, language rigors and the parent-student relationship based on fear, means students are still afraid to express themselves freely and to support their opinions. This aspect will decrease the motivation to learn, resulting in counterproductive behavior.

In our opinion, positive feedback in any situation, at home, at school, at work, in society, improves, intensifies and accelerates productivity, motivation and maintains the desire to perpetuate well-being, in contrast to the fear I mentioned previously.

Positive feedback is the force that generates the mechanisms necessary for the cohesion and proper functioning of an individual or a team. When used correctly, it becomes a "coach" that motivates and engages all team members. But misused, or offered at the wrong time, can destroy the balance of the individual or group, while also affecting individual motivation and self-esteem, and subsequently the level of motivation of the group.

That is why the teacher, by knowing the effect it can produce through his actions, must choose activities that generate, primarily for students, a correct self-analysis, activities that create moments of social analysis, in a team, and only then to issue judgments of opinion on the activity of the students involved.

"Self-esteem is the evaluative component of the self and refers to emotional experience, the emotions that the person experiences when referring to their own person" (Constantin, 2004). Psychologists characterize self-esteem as an assessment we make of our self-worth as a person, and it can merge or identify with the feedback we receive from people with "authority" (Harris \& Orth, 2020).

Positive feedback builds a strong motivation to participate in activities, which in turn brings appreciation. Appreciation strengthens a positive selfimage, increases self-esteem, contributing to a cognitive, emotional and behavioral state that creates a self-perceived identity in a positive sense (Pajares, 2012).

The educational system, in the current context, must contribute to the development of the student for life and encourage individuality, creativity, initiative, autonomy and also to contribute to the general human progress.

Children are extremely receptive to role models. The way they are treated determines the way they behave. For many of them, school is the first experience outside the home. They will need a lot of attention and protection until they are confident enough to explore and participate in all the activities that society can offer.

Essential conditions for the efficiency of feedback would be, firstly, for the teacher to know the level of development of his students and to clearly establish his objectives. Secondly, for students to know very clearly where they stand and what level they have reached or are working towards.

It is easy to understand that properly used feedback, given at the right time, and received appropriately, increases motivation and involvement, and brings confirmation (or suggests directions for improvement) about how it was done. The child will learn, through age-appropriate methods, what he needs for his harmonious development at this age and to successfully cope with information-centered school requirements.

The schooling stage represents an important moment for stimulating the student's flexibility of thinking and creativity. According to cognitive 
psychology, it is important to know the internalised experiences of students and the motivating factors, because they are associated with different types of behaviors (Graham \& Weiner, 1996). In this sense, the teacher will insist on developing the child's interest in learning and on developing self-confidence. Interactive teaching processes will predominate, providing the context for active participation, individually and in groups, allowing the free expression of their own ideas and feelings. The feedback received can help students to self-evaluate, to create a constructive model and use it in accordance with the objectives set by mutual agreement with the factors involved.
What happens in "class" should take place in the form of a training suite, listed above, that not only has the role of developing critical thinking, but creates a pattern of analysis consistent with the teacher's thinking. The task chosen by the teacher impacts the student's performance, which is why the students' attributions will influence their actions (Graham \& Weiner, 1996). The student will resonate with the way the feedback is given and will look positively at the teacher's interventions. Thus, for teachers who have not formed a habit of using feedback as a teaching strategy, discovering its positive valences, in as varied contexts as possible, can find it a challenge. In Table 1 , we propose below a system of strategies for approaching feedback, which the teacher can use depending on the contexts he demands.

Table 1. Strategies for applying positive feedback effectively

\begin{tabular}{|c|l|l|}
\hline $\begin{array}{l}\text { Nr. } \\
\text { crt. }\end{array}$ & \multicolumn{1}{|c|}{ Strategy } & \multicolumn{1}{|c|}{ Description } \\
\hline 1. & „Sandwich" Feedback & $\begin{array}{l}\text { Compliment - making recommendations for improvement / improvement - } \\
\text { compliment. }\end{array}$ \\
\hline 2. & $\begin{array}{l}\text { Feedback provided on } \\
\text { time }\end{array}$ & $\begin{array}{l}\text { The feedback must be provided immediately. Feedback that is expected means lost } \\
\text { time. }\end{array}$ \\
\hline 3. & Individual feedback & $\begin{array}{l}\text { The individual needs of the student are identified through a self-analysis performed by } \\
\text { the student together with the teacher. Questions such as "what do you think?", "what } \\
\text { would you like to consolidate?", can be a resource in establishing an improvement plan } \\
\text { (Marzano, 2005). }\end{array}$ \\
\hline
\end{tabular}

4. Feedback provided by answering the four questions

$\checkmark$ What can the student do?

$\checkmark$ What can't the student do?

$\checkmark$ How does the student's activity compare to that of others?

$\checkmark$ How can the student do better?

5. Specific feedback

Providing punctual feedback on a specific skill or knowledge that can be used as praise.

6. „Check-in” feedback

It is offered constantly, on objectives and is meant to establish a learning pattern.

7. Individual meetings completed with the appreciation of a recently achieved goal

One-on-one positive conference lasting up to 10 minutes

\begin{tabular}{|c|l|}
\hline 8. & Short feedback \\
\hline 9. & $\begin{array}{l}\text { Progressively built } \\
\text { feedback / sequential } \\
\text { feedback }\end{array}$ \\
\hline
\end{tabular}

10. Work tasks performed

Verbalized by short encouragements (yes, that's right, try again).

Students receive feedback after each learning sequence.

Schedule of tasks for students, which at the time they are performed, are marked with 
\begin{tabular}{l|l} 
successively, with & a sticker.
\end{tabular}

displayed results

showing progress

11. The concept of "peer to peer"

12. "Guest" feedback

13. Taking notes and asking for feedback from the student

14. Correspondence notebook

15. Discussions between teacher and student and common analyzes about tests, papers or objectives from the beginning of the school year

16. Feedback on notes or post-its

17. Genuine praise

18. Time to say "I noticed"

19. The "yes, no" model
Feedback provided by the student to another student.

Another adult from outside will be involved in providing feedback.

The student takes notes, compares them in pairs to complete them, and then receives feedback in pairs from the teacher.

Specific tool where the teacher notes comments, puts stamps or other rewards.

Allow students to ask the necessary questions and have a relevant discussion, to analyze themselves correctly and to observe the real progress, where they are and what they want to buy (Marzano, 2005).
The teacher writes a brief comment for the student a note. It is not the most efficient use of a teacher's time, but it is extremely efficient in terms of the effect created.

The repetition of certain words specific to praise is avoided (bravo, excellent), without concretely mentioning the reason (Black \& William, 1998).

Often teachers do not have time to express the observation of progress. Recognizing the efforts a student makes is a solid foundation for positively influencing performance.

It can be demonstrated to students what we are looking for, for a positive impact. At the end, students will compare their work with the models offered and if necessary, a remediation plan is established with them.

The student's chance to "grade" the teacher, b giving an opinion about his activity.
We believe that we can conclude by stating that the use of feedback as a tool, in any context, by the fact that it generates satisfaction and well-being, is a strategy with a strong formative character. We found no logical explanation and no evidence that unconditional help from a teacher would not produce positive results in increasing students' self-esteem and a positive self-image. In obvious contrast, however, there is undoubtedly the manifestation of authority based on power, control and punishment.

Authors note: The authors had equal contributions to this article.
Adina O. Câmpean (Primary teacher) is currently a $\mathrm{PhD}$ student at the Doctoral School "Education, Reflection, Development" (domain: Sciences of Education), Babeș-Bolyai University, Cluj-Napoca, Romania, and associate teacher at Faculty of Psychology and Educational Sciences, Cluj-Napoca, Romania. She is also supporting the integration of children in difficult circumstances in collaboration with Peace Action, Training and Research Institute of Romania. Her professional and research interests are: children wellbeing and development, influence of positive role models, factors that affect students' motivation. 
Horia Corcheș teaches Romanian language and literature at the George Bariţiu National College in Cluj-Napoca and is currently a doctoral student at Babeș-Bolyai University. He is a school inspector, he has a permanent column in Dilema Veche magazine, where he writes articles on education. His research interests are oriented towards the didactics of reading, being concerned with the mechanisms by which reading identification is an essential stage in the process of understanding and interpreting the text, from the perspective of including said texts in the wider process of personal development. He is also concerned with the means by which non-formal education can intermingle, in the instructionaleducational process, with formal education.

\section{References}

Bain, K. (2004). What the Best College Teachers Do. Cambridge, Massachusetts: Harvard University Press.

Baumeister, R.F., Smart, L., \& Boden, J. M. (1996). Relation of Threatened Egotism to Violence and Aggression: The Dark Side of High Self-Esteem, Psychological Review, Jan., 103(1):5-33. Available at: https://doi.org/10.1037/0033-295x.103.1.5 (accessed at 18.02.2021).

Bocoş, M., 2017. Didactica disciplinelor pedagogice. Un cadru constructivist. Pitești: Editura Paralela 45.

Black, P., \& Wiliam, D. (1998). Inside the black box: Raising standards through classroom assessment. Phi Delta Kappan, October, pp. 139-148.
Constantin, T. (2004). Memoria autobiografică; definirea sau redefinirea propriei vieți. Iași: Editura Institutului European.

Graham, S., \& Weiner, B., 1996. Theories and Principles of Motivation. In D. C. Berliner, \& R. Calfee (Eds.). Handbook of Educational Psychology. New York: Macmillan.

Harris, M. A., \& Orth, U. (2020). The link between selfesteem and social relationships: A meta-analysis of longitudinal studies. Journal of Personality and Social Psychology, 119(6), 1459-1477. Available at: http://dx.doi.org/10.1037/pspp0000265 (accesed at 10.02.2021).

Pajares, F. (2012). Motivational role of self-efficacy beliefs in self-regulated learning. In D. H. Schunk \& B. J. Zimmerman (Eds.). Motivation and self-regulated learning. Theory, research, and applications ( $\left.1^{\text {st }} \mathrm{ed}.\right)$. New York: Routledge.

https://edu.ro/sites/default/files/_fi\%C8\%99iere/Legislatie /2020/LEN_actualizata_octombrie_2020.pdf (accesed at 15.01 .2021 ).

http://www.marzanoandassociates.com/pdf/ShortVersion. pdf (accesed at 10.11.2020).

https://www.wilsoncenter.org/sites/default/files/media/doc uments/article/RAPORT\%20FINAL_\%20CADCR.pdf (accesed at 10.02.2021). 
Towards a Transdiciplinary Systemic Approach to National Heritage-Based Learning. Curricular Insights into the Romanian Art Education Reform in the Glocal Transformative Age

Mihaela-Gabriela Cosma Oneţ 


\title{
Towards a Transdiciplinary Systemic Approach to National Heritage-Based Learning. Curricular Insights into the Romanian Art Education Reform in the Glocal Transformative Age
}

\author{
Mihaela-Gabriela Cosma Oneț ${ }^{\mathrm{a}^{*}}$
}

\begin{abstract}
${ }^{a}$ Doctoral School "European Dynamics (DynamE)", Faculty of Humanities and Social Sciences. European Prospects, University of Strasbourg, 4 Blaise Pascal Street, Strasbourg, 67081, France

${ }^{a}$ Doctoral School "Educational, Reflection, Development", Faculty of Psychology and Educational Sciences, Babeș-Bolyai University Cluj-Napoca, Romania, 7 Sindicatelor Street, 400029, Romania

*Corresponding author: mihaela-gabriela.onet@etu.unistra.fr
\end{abstract}

\section{Abstract}

Keywords:

National Heritage learning; transdiciplinarity; curriculum planning; transformative learning; systemic approach; glocal; arts and culture experiences.
The aporia of the collapsology threats in the contemporary era of globalization, as well as our need for psychosocial-ecological resilience and well-being have shown the crucial imperative to improve education. Thus, it is through innovating the curriculum design and its intimate features that humanity will be able to restore the world's health and wealth. Consequently, the author stresses an original approach to curricula renewal in order to bridge the gap between school and society while building students' 21st century competencies. Given the challenges of today's technological and glocal era, new transformative learning pathways have been established by considering transdiciplinarity as theoretical reference. Hence, this study develops a theoretical systemic model to design a national heritage-based learning curriculum, which underpins collaborative and experiential learning. Likewise, through a transferable competency-based curriculum on national heritage, students undergo a transpersonal well-being as a holistic character-building process.

\section{Zusammenfasung}

\section{Schlüsselworte:}

nationales Erbe Lernen;

Transdisziplinarität;

Bildungsplanung; transformative Lernwege; systemische Ansatz;

glokal; Kunst und Kultur Erleben.
Die Aporie der kollapsologischen Bedrohungen in der heutigen Zeit der Globalisierung sowie unser Bedürfnis nach psychosozial-ökologischer Widerstandsfähigkeit und Wohlbefinden haben gezeigt, wie entscheidend wichtig es ist, die Bildung zu verbessern. So kann die Menschheit nur durch eine innovative Gestaltung des Lehrplans und seiner intimen Merkmale die Gesundheit und den Wohlstand der Welt sichern. Infolgedessen betont der Autor einen originellen Ansatz, zur Erneuerung der Lehrpläne, um die Kluft zwischen Schule und Gesellschaft zu überbrücken und gleichzeitig die Kompetenzen der Schüler für das 21. Jahrhundert zu stärken. Angesichts der Herausforderungen der heutigen technologischen und glokalen Ära wurden neue transformative Lernwege geschaffen, indem Transdisziplinarität als theoretische Referenz berücksichtigt wurde. Daher entwickelt diese Studie ein theoretisches, systemisches Modell, um ein nationales, auf dem kulturellen Erbe basierendes Lerncurriculum zu entwerfen, das kollaboratives und erfahrungsorientiertes Lernen. Ebenso erfahren die Schüler durch einen übertragbaren kompetenzbasierten Lehrplan zum nationalen Erbe ein transpersonales Wohlbefinden als ganzheitlichen Prozess der Charakterbildung.

\section{Introduction}

Our contemporary society is under the sway of technology and digitization. It is well-known that we are living both in the Anthropocene era (Steffen, Crutzen \& McNeil, 2007) and in The Fourth Industrial Revolution epoch (Schwab, 2015). Undoubtedly, the world has opened up but, unfortunately, climate, social and medical crises are continuously damaging our planet and destroying the humanity.

In this light, educational institutions have to undergo major restructuring, they "have to reinvent themselves" (Cardoso Espinosa, 2021, Preface, xiv), and to enable students to be highly skilled. Hence, contemporary education will be able to cope with the new existing $21^{\text {st }}$ century societal shifts while promoting students "active involvement in a formative learning process" (Bocoş \& Jucan, 2019, p. 25).

Accordingly, this paper proposes an innovative holistic theoretical model of heritage-based learning in the Romanian art education, and especially in the case of fine arts high schools. This planning of curriculum learning pathways promotes both experiential artbased and cross-curricular school subjects, as well as 
cultural learning activities based upon heritage education. These are the key topics that have been developed in this study.

From this standpoint, it is important to implement a new heritage learning planning as a curriculum renewal in the Romanian schools of arts. Moreover, one needs to design a new curriculum planning, whose contents and goals may "apply territorially or at a specific school level according to its own educational needs" (Bocoș, 2001, p. 100). In fact, this is a glocal learning approach to globality. Given that learners do collaborative work in experiential formal and nonformal learning contexts (Dewey, 1963), they learn about the common heritage of humanity and they reflect upon the destiny of the contemporary nations (Choay, 2009).

\section{Theoretical foundations and epistemological insights}

The pivotal issue addressed by this paper is a possible new societal shift in art education. From this standpoint, our specific research question is how to conceive an original theoretical systemic model of an Intangible Cultural Heritage learning in the curriculum of fine arts high schools, whose implementation will develop in our students the $21^{\text {st }}$ century crosscurricular skills for lifelong education. Furthermore, our study entails new transformative experiential curricular learning pathways, which are supposed to help learners reach their transpersonal well-being as a holistic character-building process inside and outside the classroom.

With this in mind, these major educational goals will be carried on through an epistemological approach. Thus, this paper yields insights into the scientific theoretical framework of our study as a scholarly consensus on promoting progressive New Pedagogies in order that students can reach transformative competencies (OCED, 2020), which are mindful learning outputs. Moreover, experiencing a cultural transdisciplinary education based on National Heritage studying at school inevitably entails a raise of well-being in the school environment, as a revolutionary proposal of a transformative Paideia plan (Adler, 1984).

On the basis of these scientific backgrounds, the author's standalone theoretical modelling-based approach to design an innovative heritage-based curriculum will be featured. Therefore, while both creative development of a complex systemic- interactionist models (Andronache, Bocoş \& Neculau, 2014) and didactic analogies are developed, effective heritage learning is being targeted (Glava, 2009; Glava \& Glava, 2011) in the context of art education in the Romanian secondary schools of fine arts.

In this light, this paper aims at scholarly innovating the educational insights into the national heritage study at school from a transdisciplinary perspective. This new vision of developing the curriculum planning also focuses on shaping societal adaptative competencies (Bocoş, 2010).

2.1. Transdisciplinarity in the heritage-based learning curriculum: A holistic approach to the reality of life

Owing to its features, transdisciplinary transcends a simple school subject and goes between, across and beyond (Nicolescu, 1985) the academic disciplines by fusion of knowledge, methods and spirituality. Hence, self-transformation is involved in a trans relation with the four pillars of learning, e.g., learning, learning to do, learning to be, learning to live with others (Delors, 1996; Nicolescu, 1985, 1997; Gibbons, 1994; Ciolan, 2008) towards gaining "the sense of humanity" (Ionescu, 2010, p.17). Taking into account that transdisciplinarity in education means a superior level of integration (Nicolescu, 1996; Ciolan, 2008; Morin, 1999), which transcends multidisciplinarity, innovative learning-teaching-training and regulatory feed-back evaluation processes are prioritized. Accordingly, it is through conceiving and piloting a heritage-based learning programme, especially in fine arts high school, that teachers can highlight important "entering points" to innovation (Văideanu, 1988) in this cross-curricular learning context.

Contemporary school need a real strong change so as to prepare students to build trustful human relationships. Moreover, schools of arts have to enable learners to make the choice of the best career in the future. Not only have they to be well-prepared professionally speaking, but also to be resilient, ethical and human. Hence, there is a tremendous need for a heritage education based on humanistic cultural values. This is a complex learning process which promotes identity and alterity built on a national psychanalysis (Bourdieu \& Passeron,1964; Meirieu \& Develay, 1992).

As we know, the curriculum is the main structure of implementing the learning-teaching-training framework at school. The planning and the 
development of an appropriate curricula have to bridge the gap between school, politics and society, between the theory and the practice of education, between the formal, non-formal and informal learning contexts. Henceforth, this paper is a plea for the educational eternal need for change alongside the contemporary holistic societal shift. This challenge implies not only a transdisciplinary integrated approach of the National Heritage in the optional school curricula, but also a removing plan from the "closed" school spaces towards "the open spaces". It is through finding these new learning contexts that "relatively new situations" (Păun, 2017, p. 178) are built. They are innovative didactic gateways towards the collaborative perspectives of intangible cultural heritage learning, and real world-life learning paradigm. Consequently, it is highly recommended that a National Heritagebased learning curriculum underpins a transnational approach embedding all cultures. This curricular perspective entails to foster all students' knowledge, skills, positive attitudes.

Likewise, Intangible Cultural Heritage is perceived as an experiential artistic approach to the heritage, whose major power is to connect generations through both the beauty of art and the fascination of history (Choay, 2009). Furthermore, National Heritage in school curriculum can be a powerful key concept based on the sociocultural theory, which in fact meets the requirements of the Yin-Yang Curriculum vision framework (Twining, 2020).

Given the international community agreement to unite all forms of heritage under the holistic concept of Intangible Cultural Heritage (UNESCO, 2003), throughout this paper the terms of "Intangible Cultural Heritage", "heritage" and "national heritage" are used interchangeably to include collective tangible and intangible elements of specific cultural heritage.

\subsection{Going glocal: outlining the glocality through} the National Heritage learning modelling

According to Encyclopedia Britannica (2007) the concept of glocality was popularized by the sociologist Roland Robertson. However, Friedman's monetarist theory to "think global, act glocal" (Friedman, 1999, pp. 7-8) has become a transdisciplinary concept, which has been creatively endorsed by other sciences.

Apart from this, in the scholarly literature it is increasingly recognized that glocalization indicates that the growing importance of continental and global levels is occurring together with the increasing salience of local and regional levels. Glocalization appears alongside tendencies of heterogeneity and decentralization.

In this paper, glocality is seen as a new perspective of the paradigm shift of the worldwide globalization from a cultural and pedagogical perspective.

On the one hand, the intent is to plan and to promote a nonformal heritage learning process, which focuses in this curriculum on experiencing glocalization. Following the Garcia's (2020) vision of glocalization, the students of fine arts high schools will learn to interiorize National Heritage as a shaping of local spaces and identities both by globalized contacts and by local circumstances. Thus, glocality can be pedagogically put into practice through implementing a local curriculum learning, whose contents and goals may "apply territorially or at a specific school level according to its own educational needs" (Bocoș, 2001, p. 100).

On the other hand, it is necessary to take into account the power of art both to bring added value to national heritage and to keep its collective memory alive through valuable transmission. In this light, art is seen as an intimate way of thinking, the very essence of our societal identity (Somé, 2019).

Keeping this in mind, it is necessary to recognize at all educational levels the need of experiencing a shaping of local spaces and identities both by globalized contacts and by local circumstances (Encyclopedia Britannica, 2007). This is one of the most valuable way for Romanian and European learners to become aware of the unicity and universality of their cultures.

\subsection{A model of transformative and never-ending} learning curriculum design

There is a contemporary wind of change in education, as a result of the tremendous learning process need "to transform in order to be transformative" (Sterling, 2001, p. 19). From this perspective, transformative learning planning is an innovative approach to teaching-learning, where educators challenge learners to critically review relation to the world around them (Mezirov \& Tylor, 2010).

Given that developing character features follows a typical established process of re-building a strong personality (Chiş, 2014), a transformative learning scenario is carried out by our analytic heritage-based 
learning model. Hence, a creative trans-personality is supposed to be shaped not only through co-teaching, but also through teaching contextualization of cultural processes which are intertwined with best learning practice (Mezirov, 2012; Mizzi et al., 2017). Moreover, this transformative learning scenario also entails enhancing cultural identity and diversity (Jeannin, 2017). Given this panorama, this new heritage-based curricular planning underpins a collective trans-formation under the sign of heritage study. In fact, this is achievable through a large array of new disciplines, such as literature and old schools' heritage, the time dimension of the collective memory, aesthetic heritage, etc. (see Figure 1). Therefore, participants can learn how to develop strong relationships between their identity and the otherness, while mediating cultural conflicts or via "reflective thinking" (Dewey, 1963).

In addition, learners become aware of the need to preserve the nature as a precious element of heritage (Davallon, 2010). Consequently, they can also reframe their relationship with the environment, and to crystallize never-ending learning skills according to the theories of "transformation" and development (Mezirov, 2012).

\section{A mindset systemic approach to design the National Heritage-based school learning}

National Heritage is seen as a resource of territorial development at all levels of the society. It is obvious that its knowledge enhances the social participatory sustainability, via experiencing formal, informal and nonformal learning pathways (see Figure $1)$.

In this paper the concept of heritage is seen in the light of the stipulated regulations in the 2003 UNESCO's Convention for the Safeguarding of the Intangible Cultural Heritage. According to this document, the "intangible cultural heritage" embodies all cultural elements upon which communities unanimously agree to be part of their cultural heritage, Thus, along with non-tangible elements such as "practices, representations, expressions, knowledge, skills", there are also tangible elements of culture, e.g. "the instruments, objects, artefacts and cultural spaces associated therewith" (UNESCO, 2003, Art. 2), so as to be included in the Intangible Cultural Heritage. As we know, without the memory touch, heritage ends its important societal signification, and all cultural object, various landscapes, wildlife and natural resources have to be meaningful for communities in order to be acknowledged as part of National Heritage through an institutionalized heritagization process (Choay, 1992; Davallon, 2014; Bortolotto, 2011). On the other hand, modelling a $21^{\text {st }}$ century transdisciplinary heritage competency-based learning plan implies undoubtedly collaborative and experiential viewpoints, because its main purpose is to study in situ the psychological features of a nation, the heart and the spirit of a people (Negruţiu, 2005).

With this in mind, the author's original proposal to the existing epistemological background of both transdisciplinary and heritage education is built on the systemic model construct of a heritage-based learning curriculum in the context of fine arts high schools.

Accordingly, our mindsight model to design the National Heritage-based learning is seen as a systemicinteractionist mental mind mapping of the cross curricular planning phase. According to Ciolan (2008, p. 164), this is the first and the major "innovative driver" of the transdisciplinary curriculum building, a crucial premise for the further curriculum development processes. Furthermore, this learning model focuses on empowering students to empathically perceive vernacular or vehicular, both national and universal human mind and soul via experiencing "anthropology and philosophy of the sensibility" (Somé, 2017) as well.

The author's original proposal to the existing theory includes an outline of a systemic heritage-based learning curriculum planning to provide art schools pupils with the $21^{\text {st }}$ century long lasting transdisciplinary competencies. This flexible curriculum tool aims to also reach personal wellbeing, and planetary sustainability (OCED, 2020).

With regard to this, it is important for teachers to design creative transdisciplinary curricula shaped on heritage education, which can be piloted mainly in fine arts fine high schools, as a part of a new paradigm of the Progressive Education via collaborative and experiential learning (see Figure 1 below). Thus, it is through learning about heritage by taking an ethnological and anthropological approach in nonformal contexts that students can foster knowledge, skills and values in a differentiate and interiorized manner, while deepening common moral consciousness. Furthermore, it is likely that this heritage-based learning will promote complex learning styles and modern long life learning paradigms. These learning processes also stimulate the 
motivation for studying, as well as "the openness to positively react to any change" (Bocoş, 2001, p 105).

3.1. A theoretical systematic model of heritagebased learning in the contemporary fine arts high schools

The following pages will present an original use of the paradigm of models and analogies in educational sciences. Thus, this innovative paradigm is focused on fostering original formative didactic learning strategy by promoting "new desirable learning experiences" (Bocoş \& Jucan, 2019, p. 22) through a heritage-based curricular approach. It is well-known that a scientific modelling approach enhances effective learning (Glava, 2009; Glava \& Glava, 2011). It also helps teachers to create a meaningful "systemicinteractionist model" (Andronache, Bocoş \& Neculau, 2014) of a heritage competencies-based learning curriculum, which is life long-learning oriented. From an Intangible Cultural Heritage-based learning perspective, Figure 1, below, suggests that the students of fine arts high school can undergo transformative, collaborative and trans experiential learning processes through a transdisciplinary mixture of a large array of subjects taught in each Romanian school of arts.

Thus, Figure 1, below, is a powerful argument to promote transdiciplinarity by studying ethography, museology, geoculture, identity and otherness in Romanian artistic education. In this way, students could become resilient and reach the Nicolescu's Hidden Third as a transpersonal well-being through "understanding cultural differences" (Hall \& Hall, 1990).

While analyzing this conceptual learning model, the first level of our Intangible Cultural Heritage programme embodies an overview of the pedagogical mezzo level curriculum seen as "a complex, dynamic social phenomenon" (Bocoş, 2007, p.17). This is in line with the interactive-based, integrated fusion of school subjects into that of Intangible Cultural Heritage from a socio-cultural perspective.

The heritage-based teaching-training-learning process is shaped so as to include all transdisciplinary heritage elements, from a diachronic and synchronic perspective, as well as from a cultural artistic angle.

Moreover, this approach of heritage curriculum also focuses on studying natural heritage. In addition, there are various practical learning insights into both national and European heritage through ethnography and anthropology, as Figure 1 shows.

Generally speaking, this curriculum concept has also foreseen students' practical immersion in situ, i.e., into the richness of real local heritage trades. Thus, there will be opportunity for students to think about choosing a future career in the field of preserving or promoting heritage via practicing ancient or modern skilled jobs or ancestral craftsmanship. Therefore, students may as well give rise to the future National Heritage through creative artistic professional work for livelihoods, whom Adell (2016) metaphorically called "jobs inside heritage".

Figure 1. The Intangible Cultural Heritage learning in the contemporary school as a didactic model (Original work)

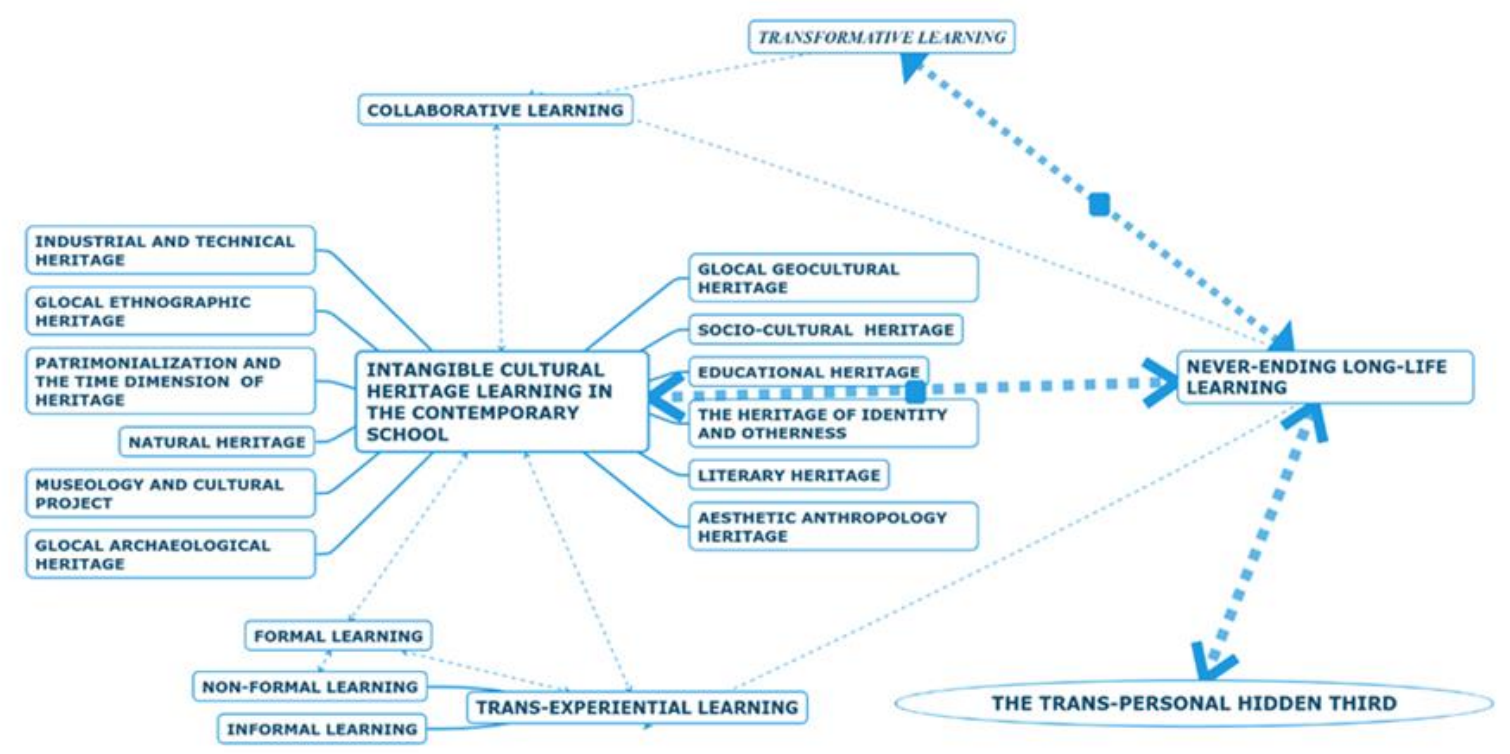


As shown in Figure 1 above, it is the Nicolescu's Hidden Third that is the main trans personal goal to be attained by all participants involved in this innovative cultural learning process, i.e., students and their educational partners. In addition, it becomes clear that this emotional effect is considered to be the peak learning performance, as well as a way to gain transformative, collaborative, long life lasting skills. These transdisciplinary heritage competencies are deemed to be main educational desiderata, and they can only be reached through a large array of transdisciplinary practical learning tools. In this light, this learning systemic model clearly promotes different embedded learning concepts and styles, as a starting point to further curricular processes of "the eightfold path of the curriculum" (Ciolan, 2008, p. 164). Thus, all these processes of this first curricular shaping phase - e.g., heritage contents, learning contexts, and goals perspectives - are interwoven under the holistic cupola of Intangible Cultural Heritage topic.

At the second level, there is the humanistic heritage learning dimension which is highlighted. Consequently, strong relationships based on both identity and diversity learning are built between all participants in the heritage learning process. Thus, participative, collaborative and experiential strong bonds between the members of the educational classic triangle (Bocoş, 2008, p. 25) are reset through artdoing and through preserving National Heritage. Moreover, these relationships will be also strengthened between all participants who take part in learning about heritage in various informal and nonformal learning contexts, i.e., heritage professional guests.

Furthermore, as shown in Figure 1, we lay great weight on strengthening the role of nonformal and informal artistic cultural contexts so as to make students gain new transdisciplinary skills. Thus, transformative new competencies are supposed to be developed via the Intangible Cultural Heritage curriculum shaping, which becomes resourceful for both educational and economical sustainability through experiencing (Dewey, 1963) its growth and impact.

At the third level, by examining the complexity of the multilevel rapports between heritage and the territorial level of the learning process, multiple glocal insights into the major heritage components have been foreseen. Consequently, it is vital to adapt the curriculum content and learning strategies as a global stream which is glocally transformed into a local culture. However, as Boyd \& Richerson (2009) stated, this new glocal culture will be reincorporated into a newer global one, by following a constant cycle movement.

On the upper level of the heritage learning processes of our transdisciplinary integrated curriculum framework, we explore art diversity and power of positioning as catalysts for learning about culture and civilization. According to Figure 1, our systemic learning process develops a transversal approach to heritage conservation and restoration in terms of esthetic learning of the heritage of otherness, for instance. The latter is seen from an anthropological point of view as a powerful tool for learning heritage. As Somé (2019) said, the anthropology of art has to be perceived in fact as a cultural and civilizational bond between different people all over the world, as a benchmark of the universality of the human being. Thus, heritage learning promotes transdisciplinary through valorizing paradigms and key concepts as identity, national, glocal and European treasures, agency and participation. Moreover, this heritage learning pathway design aims at "educating the students' feelings and characters" (Ionescu, 2010, p.21), as a backbone of generating well-being at school, which is hidden in the Nicolescu's Third Level of Reality (1996). In our view, this is the only way to outreach the educational crisis and our Planetarium Era's (Morin, 1999) challenges.

\section{Conclusions}

A few interesting conclusions emerge from an overview of this background paper. As we know, both practitioners and theoreticians have to keep students' learning profile development in mind, and its usefulness across the lifespan. Thus, this article details a new approach to cross-curricular learning of national heritage in the context of Romanian fine arts high schools, which goes beyond the disciplines (Nicolescu, 1985, 1996).

The main goal of our curriculum development planning is not only to show how to bring school closer to the society, but also to make learning a better place through building a heritage learning organization group. Thus, students' motivation and joy of learning are visibly strengthened by various non formal and informal heritage learning contexts (Hattie, 2009). 
Undoubtedly, preserving National Heritage, experiencing transdiciplinarity and glocality through learning about our cultural, material or scientific richness, about the values of otherness are precious conceptual transformative learning frameworks. One can say that this heritage learning curricular pathway helps young Romanian future artists to acquire the lifelong learning skills, to choose a future career, to adapt to the glocalized society through collaboration and empathy. Finally, students may be able to build "outstanding societies" (Somé \& Roux, 2017), and to become aware of being "part of this Reality that changes due to our thoughts, feelings and actions" (Nicolescu, 2012, p. 717).

\section{Acknowledgments}

First and foremost, the author's special thanks go to her Professor and Romanian Thesis Supervisor, Mrs. Muşata-Dacia Bocoş, for her creative suggestions, and for her unconditional emotional support and trust. The author wishes to acknowledge her valuable contributions regarding the proofreading of my article, for her meticulous attention to detail.

\section{Authors note:}

Mihaela-Gabriela Cosma Oneț is an international $\mathrm{PhD}$ student in the field of Educational Science, Social Sciences and European Perspectives. She is currently developing an international jointlysupervised thesis between the University of Strasbourg, France and Babeş-Bolyai University, Cluj-Napoca, Romania. As a teacher at R. Ladea Fine Arts High School in Cluj-Napoca, Romania, her scientific research addresses the epistemological background of Heritage Education and its impact on transdisciplinary students' learning outcomes. Mrs. Oneţ also coordinated an intercultural Erasmus+ project on National Heritage and she is involved in the activity of the Erasmus+ programmes hub at school. Owing to her specialization in Geomorphology, Educational and Tourism Management, her scientific research and interests are focused not only on transdisciplinary learning activities about National Heritage, but also on complex partnerships with French high schools or local, regional and national NGOs, through volunteering.

\section{References}

Adell, N. (2016). Le sens de la visite. In Le tournant patrimonial: Mutations contemporaines des métiers $d u$ patrimoine Hottin, C. \& Voisenat, C. (Eds.) Paris: Maison des Sciences de l'Homme.
Adler, M.J., \& the Paideia Group. (1984). The Paideia program: An educational syllabus. New York: Macmillan.

Andronache, D., Bocoş, M. \& Neculau, B.C. (2014). A systemic-interactionist model to design a competencybased curriculum. Procedia-Social and Behavioral Sciences.180 (2015), 715-721. London: Elsevier. Available at: www.sciencedirect.com ScienceDirect1877-0428 (accessed at 12.09.2020).

Bocoş, M. (2001). Curriculumul şcolar şi aspectele sale esenţiale. In M. Ionescu \& I. Radu (Eds.) Didactica modernă. Ediţia a II-a, revizuită. Cluj-Napoca: Editura Dacia.

Bocoş M. (2007). Didactica disciplinelor pedagogice. Un cadru constructivist. Ediţia a II-a, revăzută. Piteşti: Editura Paralela 45.

Bocoş, M. \& Jucan, D. (2019). Fundamentele pedagogiei. Teoria şi metodologia curriculumului. Repere şi instrumente didactice pentru formarea profesorilor. Ediţia a IV-a. Piteşti: Editura Paralela 45.

Bocoş, M. (2010). Formarea didactică la Universitatea Babeş-Bolyai. Semnificări şi resemnificări în diacronie. In Ionescu, M. (Ed.) Şcoala clujeană de pedagogie - 90 de ani. Cluj-Napoca: Casa Cărţii de Ştiinţă.

Bortolotto, C. (Ed.) (2011). Le Patrimoine culturel immatériel. Enjeux d'une nouvelle catégorie. Paris: Maison des Sciences de l'Homme.

Bourdieu, P. \& Passeron, J.C. (1970). La reproduction. Éléments pour une théorie du système d'enseignement. Paris: Éditions de Minuit.

Cilers, P. \& Nicolescu, B. (2012) Complexity and transdisciplinarity - Discontinuity levels of Reality and the Hidden Third. Futures, 44(8), pp. 711-718. Available at: https://www.sciencedirect.com/journal/futures/vol/44/is sue/8 (accessed at 12.12.2020).

Boyd, R. \& Richerson, P.J. (2009). Culture and the evolution of human cooperation. The Royal Society Publishing, Vol. 364, Issue 1533:3281-3288. Available at: https://royalsocietypublishing.org/doi/abs/10.1098/rstb. 2009.0134 (accessed at 13.12.2020).

Cardoso Espinosa, E.O. (Ed.) (2021). Developing Mathematical Literacy in the Context of the Fourth Industrial Revolution. Santo Tomás: Instituto Politécnico Nacional.

Chiş, V. (2014). Fundamentele pedagogiei: repere tematice pentru studenţi şi profesori. Ediţie bilingvă. Cluj-Napoca: Editura Eikon.

Choay, F. (1992). L'Allégorie du patrimoine. Paris: Seuil. 
Choay, F. (2009). Le Patrimoine en questions, sous-titré Anthologie pour un combat. Paris: Seuil.

Ciolan, L. (2008). Invăţarea integrată. Fundamente pentru un curriculum transdisciplinar. Iaşi: Editura Polirom.

Davallon, J. (2010). The Game of Heritagization. pp. 3962. In Constructing Cultural and Natural Heritage: Parks, Museums and Rural Heritage. Xavier Roigé \& Joan Frigolé, (Eds.) Girona: Institut Català de Recerca en Patrimoni Cultural.

Dewey, J. (1963). Experience and education. New York: Collier Books.

Friedman, T.L. (1999). The Lexus and the olive tree. New York: Farrar, Straus, Giroux.

Garcia, H.E. (2020). Optimizing Globalization Will Become Possible with a New Paradigm. In Interdisciplinary Journal of Partnership Studies, Vol.7, No.1. Available at: https://pubs.lib.umn.edu/index.php/ijps/article/view/30 29 (accessed at 1.02.2021).

Gibbons, M. et al. (1994). The New Production of Knowledge: The Dynamics of Science and Research in Contemporary Societies. London: Sage Publication Ltd. Available https://www.researchgate.net/publication/225088790_T he_New_Production_of_Knowledge_The_Dymics_of_ Science_and_Research_in_Contemporary_Societies (accessed at 2.11. 2020).

Glava, A.-E., \& Glava, C.C. (2011). The model and the didactic modelling an analytic point of view. Procedia Social and Behavioral Sciences, 15, 2228-2231, 2011. London: Elsevier. Available at: https://www.sciencedirect.com/science/article/pii/S187 7042811006306 (accessed at 7.11. 2020).

Glava, C.C. (2009). Formarea competenţelor didactice prin intermediul e-learning: modele teoretice şi aplicative. Cluj-Napoca: Casa Cărţii de Ştiinţă.

Hall, E.T. \& Hall M.R. (1990). Understanding cultural differences: Germans French and Americans, ME: Intercultural Press, Yarmouth.

Hattie, J. (2009). Visible Learning: A Synthesis of Over 800 Meta-Analyses Relating to Achievement. London: Routledge.

Ionescu, M. (2010). Şcoala clujeană de pedagogie după înfiinţarea universităţii româneşti şi principalele direcţii de studiu şi acţiune - Abordare diacronică. In Ionescu, M. (Ed.) Şcoala clujeană de pedagogie - 90 de ani. Cluj-Napoca: Casa Cărţii de Ştiinţă.

Ionescu, M. \& Chiş, V. (2001). Metodologia activităţii didactice între rutină şi creativitate. In M. Ionescu \& I.
Radu (Eds.). Didactica modernă. Ediția a II-a, revizuită. Cluj-Napoca: Editura Dacia.

Jeannin, L. (2017). The adaptation process of international lecturers in a South African university: The centrality of agency and collegiality. Journal of Research in International Education, SAGE Publications, 2017, 16 (3), pp. 236-247. Available at: ff10.1177/1475240917746035ff. ffhal-01892135f (accessed at 10.09.2020).

Meirieu, P. \& Develay, M. (1992). Émile, reviens vite... Ils sont devenus fous. Paris: ESF.

Mezirov, (2012). Transformative Dimensions of Adult Learning. 1st Edition. Los Angeles: The Jossey Education Series.

Mizzi R.C., Rocco, T. \& Shoe S. (Eds.) (2017). Disrupting Adult and Community Education: Teaching, Learning, and Working in the Periphery. Albany: State University of New York Press.

Morin, E. (1999). Relier les connaissances. Le défi du XXIe siècle. Paris: Seuil.

Negruţiu, S. (2005). Valorificarea folclorului în invăţământul primar: scenarii educaţionale. ClujNapoca: Casa Cărţii de Ştiinţă.

Nicolescu, B. (1985) Nous, la particule et le monde. Paris: Éditions Le Mail.

Nicolescu, B. (1996). La transdisciplinarité (manifeste). Monaco: Éditions du Rocher.

Nicolescu, B. (2012). The Transdisciplinary Evolution of the University Condition for Sustainable Development. CIRET Centre International de Recherches et études Transdisciplinaires. Paris. Available at: http://cirettransdisciplinarity.org/bulletin/b12c8.php (accessed at 15.10.2020).

Păun, E. (1999). Şcoala, abordare sociopedagogică. Iaşi: Polirom.

Păun, E. (2017). Pedagogie - Provocări şi dileme privind şcoala şi profesia didactică. Iaşi: Editura Polirom.

Schwab, K. (2015). The Fourth Industrial Revolution. What It Means and how to Respond. Foreing Affairs. Available at https://www.foreignaffairs.com/ articles/2015-12-12/fourth-industrial-revolution (accessed at 17.10.2020).

Somé, R. (2004). Le musée à l'ère de la mondialisation. Pour une anthropologie de l'altérité. Paris: L'Harmattan.

Somé, R. (2017). Anthropologie et philosophie du sensible. Saint-Denis: Connaissances et savoirs.

Somé, R. (2019). Support de cours 2019. Anthropologie de l'art. Université de Strasbourg. 
Somé, R. \& Le Roux, P. (2017). Sociétés et êtres d'exception. Approche interdisciplinaire et des sciences participatives. In Séminaire «Ethnologie et archéologies». Université de Strasbourg. Available at: file:///F:/Articol\%20Roger\%20Some.pdf (accessed at 25.01. 2020).

Steffen, W., Crutzen, P. \& McNeill, J. (2007). The Anthropocene: Are Humans Now Overwhelming the Great Forces of Nature? AMBIO: A Journal of the Human Environment, 36(8), 614-621.Available at: https://pubmed.ncbi.nlm.nih.gov/18240674/ (accessed at 12.02.2021).

Sterling, S. (2001). Sustainable Education: Re-visioning Learning and Change. London: Edition Green Books.

Twining, P., Butler, D., Fisser, P., Leahy, M., Shelton, C., Forget-Dubois, N., \& Lacasse, M. (2020). Developing a quality curriculum in a technological era. Educational Technology Research and Development. Springer Nature Swizerland, 1-24. Available at: https://www.ncbi.nlm.nih.gov/pmc/articles/PMC76570 $67 /$ (accessed at 10.02.2021).
Văideanu, G. (1988). Educația la frontiera dintre milenii. București: Editura Politică.

Encyclopedia Britannica. (2007). London: Encyclopaedia Britannica, Inc.

International Commission on Education for the Twentyfirst Century. Delors, J., \& Unesco. (1996). Learning, the treasure within: Report to UNESCO of the International Commission on Education for the Twentyfirst Century. Paris: Unesco Pub.

OCED. (2020). The OECD Future of Education and Skills 2030. Conceptual Learning Framework - The Learning Compass 2030. Available at: https://www.oecd.org/education/2030-project/teachingand-learning/learning/ (accessed at 03/02/2021).

UNESCO. (2003). Text of the Convention for the Safeguarding of the Intangible Cultural Heritage. Available at: https://ich.unesco.org/en/convention (accessed at 15.10.2020). 


\section{Parent Personality Traits During Covid-19 Pandemic: a Correlational Study}

Cristina S. Sălăgean, Editha Coşarbă 


\title{
Parent Personality Traits During Covid-19 Pandemic: a Correlational Study
}

\author{
Cristina S. Sălăgean ${ }^{a^{*}}$, Editha Coşarbă ${ }^{b}$ \\ ${ }^{a, b}$ Doctoral School "Education, Reflection, Development”, Babes-Bolyai University Cluj-Napoca, 7 Sindicatelor Street, 400029, Romania \\ *Corresponding author: salcristina@yahoo.com
}

\section{Abstract}

Keywords:

Covid-19; parents; anxiety; selfefficacy; distrust.
The COVID-19 pandemic has had a sudden and profound impact on international communities. The emergence of COVID-19 has led to drastic measures to ensure social distancing throughout the world, in order to prevent disease. In Romania, prevention measures regarding the infection with the new coronavirus and the limitations imposed at national level suddenly changed the routines and interactions of the population and made many parents feel overwhelmed due to work at home, home-schooling and family care, simultaneously. The national home quarantine policy may have influenced parents' mental health. The present study aimed to investigate the anxiety, self-efficacy, anger, energy level, distrust and frustration about the basic psychological needs of parents during the COVID-19 pandemic and to explore the relationship between them.

\section{Zusammenfasung}

Schlüsselworte:

Covid-19; Eltern; Angst;

Selbstwirksamkeit; Misstrauen.
Die COVID-19-Pandemie hatte plötzliche und tiefgreifende Auswirkungen auf die internationalen Gemeinschaften. Das Aufkommen von COVID-19 hat zu drastischen Maßnahmen geführt, um die soziale Distanzierung auf der ganzen Welt sicherzustellen und Krankheiten vorzubeugen. In Rumänien veränderten Präventionsmaßnahmen in Bezug auf die Infektion mit dem neuen Coronavirus und die auf nationaler Ebene auferlegten Einschränkungen plötzlich die Routinen und Interaktionen der Bevölkerung und ließen viele Eltern sich aufgrund der Arbeit zu Hause, der Schule zu Hause und der familiären Betreuung zu Hause gleichzeitig überfordert fühlen. Die nationale Hausquarantänepolitik hat möglicherweise die psychische Gesundheit der Eltern beeinflusst. Die vorliegende Studie zielte darauf ab, die Angst, Selbstwirksamkeit, Wut, Energie, Misstrauen und Frustration über die psychologischen Grundbedürfnisse der Eltern während der COVID-19. Pandemie zu untersuchen und die Beziehung zwischen ihnen zu untersuchen.

\section{Introduction}

On December 31, 2019, in the Hubei region of China, several cases of pneumonia of unknown etiology were found, and a week later, the causative factor was identified as a virus belonging to the Coronaviridae family called SARS-CoV-2 (severe acute respiratory syndrome coronavirus 2 ). This new coronavirus was responsible for the respiratory syndrome called COVID-19 (World Health Organization [WHO], 2020). The disease began to spread in China, with a huge rate of contagion and deaths, which led the World Health Organization (WHO) to declare, on January 30, 2020, a public health emergency of international interest. A few weeks later, the disease was detected in many countries, COVID-19 being declared a WHO pandemic on March 11, 2020.

Although most patients who came in contact with the virus developed only mild symptoms, such as fever, dry cough, and lack of odor, with a benign course and easy recovery, some patients developed severe complications, such as pulmonary edema, interstitial pneumoniae with acute respiratory distress syndrome, multiorgan failure, septic shock, and even death (Sohrabi et al., 2020). Patients at risk were those over 60 years of age, suffering from cardiovascular comorbidities (e.g., arterial hypertension, diabetes, and chronic coronary artery disease) and affected by chronic pneumopathies or cancer (Zhou et al., 2020). In the spring of 2020, governments around the world were forced to impose drastic measures of social distancing to reduce the spread of the virus. The pandemic has caused an economic and social burden that is difficult to estimate.

This virus has become a threat not only to people's physical health, but also to their mental health. A survey conducted in China showed that almost $35 \%$ of the population suffered significant psychological distress and a variety of psychological problems, for example, anxiety (Qiu et al., 2020). Evidence of emotional impairment was also found in Western 
countries during the acute period of the pandemic (Mazza et al., 2020). Therefore, the study of mental health during the pandemic is one of the most important challenges for research, policy makers and administrations (Romero et al., 2020).

Most studies conducted so far, since the beginning of the COVID-19 outbreak or during previous pandemics have examined the psychological consequences on the general population, the analysis of effects on parents being neglected, with few exceptions. A deeper understanding of risk factors in the home environment, such as parents' mental health issues, is, therefore, very important (Spinelli et al., 2020; D. Wang et al., 2020).

This study examines the relationships between some parental personality traits, during Covid-19 pandemic.

\section{Theoretical foundation}

Considering the Covid-19 pandemic, the President of Romania decreed a state of emergency on the territory of Romania on March 16, 2020, for 30 days, and later, on April 14, it was extended for another 30 days. The establishment of a state of emergency in Romania came just several days after the World Health Organization declared a coronavirus pandemic. The state of emergency decreed in March included first-rate measures with direct applicability in the areas of public order, economics, health, labor and social protection, justice and foreign affairs, as well as firstrate measures with gradual applicability (Digi24, 2020).

When this study was conducted, schools and child care institutions in Romania were closed, over 1 million employment contracts were suspended, and the unemployment rate reached almost 7\% (Digi24, 2020). During the most restrictive period, the state of emergency, which lasted 2 months, families had to suddenly adapt their routines, work and interactions, coping with various sources of stress related to health, family health and work.

The policy of transferring learning activities from school to home had implications for changing the learning model. Some schools and teachers used several online facilities and platforms to continue teaching, but the care for children to understand the materials received, to participate in online classes and to do their homeworks was transferred to the parents. The transition from school to home-based learning has taken parents by surprise. This ideal of online schooling did not follow, in reality, the facts on the ground. Online learning has caused a lot of disorientation (Sari et al., 2020). The teacher expected home learning to be done with online assignments, and the assessment was online. They often gave tasks that required several hours to complete. As a result, tasks accumulated, and children and parents were exhausted (Sari et al., 2020).

In addition to school activities, parents were put in the situation of continuously looking for indoor leisure activities and managing children's behavior problems throughout the day. A great challenge of learning at home through the use of online learning was felt more accentuated by families with minimum economic incomes (Tedeschi et al., 2018).

Research suggests that parents experience stronger and negative responses to more acute disasters, increased anxiety and post-traumatic stress compared to those with fewer caring responsibilities (Bradley, 2007; Conger et al., 2002; Gewirtz et al., 2008; Xie et al., 2020). Parents are put in a situation where they have to find resources, in terms of their own coping and self-care, as well as their children who take the model of parents to cope with stressful situations (Deater-Deckard, 1998).

Families with children have faced many difficulties due to the loss of economic and social support. In America, more than 1 in 4 parents reported mental health problems and 1 in 7 parents reported worsening of their children's behavioral problems since the pandemic began (Patrick et al., 2020). A study in China reported that children face fear, clinging, inattention, and irritability during the COVID-19 pandemic (Jiao et al., 2020).

In general, in good times, when there is no pandemic, many parents experience specific stress related to their parenting roles (Kaya \& Fang, 1997; Mikkonen \& Raphael, 2010). For most parents, stress related to the role of parents is transient and does not result in a significant impact on life (Roskam et al., 2018; Séjourné et al., 2018). Parental unemployment, financial insecurity, low levels of social support from family and friends and lack of free time were associated with an increased risk of parental exhaustion (Lindström et al., 2011; Sorkkila \& Aunola, 2020).

Factors that influence anxiety of parents include marital satisfaction, family conflicts, social support, 
history of mental illness, parental style, level of development of the child, etc. (Wu et al., 2020).

Given the COVID-19 pandemic, parental suffering could have specific triggers, such as isolation at home, social distancing, difficulties in keeping family members safe, difficulties in keeping children busy, difficulties in supporting children's learning, difficulties in meeting the needs and requirements of children, however, while facing their own emotional issues (Romero et al., 2020). It has been suggested that parents' self-efficacy (Bandura, 1983) may protect them from life's stressors.

The results of a study by Spinelli et al. (2020) showed that the perceived difficulty of quarantine is a factor that significantly influences the well-being of both parents and children. The impact of quarantine on children's behavioral and emotional problems is mediated by the individual and dyadic stress of parents (Spinelli et al., 2020).

Just like on a plane, parents are advised to put on their own oxygen masks first, when it is an emergency, so that they can support their children effectively and keep them safe in the same way. In any crisis situation, parents must be taught how to take care of themselves if they want to support their children effectively (Coyne et al., 2020).

As parents' demands and stress increase, so do resources. Many children could become victims of domestic abuse (Usher et al., 2020). Parents face a collision of roles - employee, parent, partner, employer, business owner, friend, caregiver, teacher, etc. As they manage this collision of roles, responsibilities, and expectations, they may face fear and uncertainty about the future and how they can keep their families safe (Coyne et al., 2020). While parental suffering can cause negative outcomes for children, good mental health for parents has been more closely linked to positive outcomes for children (Romero et al., 2020).

Reports from families during the peak of COVID19 in the US indicate these stressors as being increased for parents or caregivers: anxiety or fear of infection, major changes in work / learning, daily personal care routines, and poor access to reliable information and resources (Norris et al., 2002; Prime et al., 2020; Russell et al., 2020; C. Wang et al., 2020; Xie et al., 2020).

Maintaining routines and structure in the family environment is important because routines foster a sense of coherence and management (Bradley, 2007; Romero et al., 2020). Interruption of routines, closure of schools, limitation of health care visits and changing eating habits were contributed to the deterioration of mental and behavioral health among families (Patrick et al., 2020).

Family systemic theory and parental research say that the role of parents is very complex (Connor \& Davidson, 2003; Gordillo, 2020) including the perceived responsibility to respond to the needs of multiple family subsystems. High levels of psychological distress can negatively influence the balance of care responsibilities, with parents often sacrificing their own well-being to meet the care needs of their children (Neece et al., 2012; Sameroff, 2009). Lack of adequate financial resources that leads to frustration in meeting basic needs is a factor that aggravates the mental health of the general population (Russell et al., 2020).

The COVID-19 pandemic has put many parents in a position to make difficult choices. Some have had to choose between going back to work, with the potential contamination of their homes, and working from home while coping with the growing demands for children's home education. Others had elderly parents or family members with chronic illnesses that they had to take care of and ensure their safety. For parents of children with disabilities or other health problems, the challenges were even greater.

Anxiety has been observed in parents who go to work, which can put them at high risk of contagion, but also the situation of isolation at home has led parents to face different threats (eg management workrelated problems, keeping safe, difficulties and challenges in managing the child's school work, meeting the child's needs and demands for attention, while dealing with their own emotional problems). These difficulties can create a feeling of discomfort with the requirements of care, which is combined with symptoms of anxiety in accordance with previous findings in various fields of research (Romero et al., 2020; Shea \& Coyne, 2011; Williford et al., 2007).

The study by Gassman-Pines et al. (2020) has the advantage of using daily survey data collected before and after the pandemic to investigate the hypothesis that the pandemic has worsened the psychological well-being of parents and children. The data showed that the frequency of daily negative moods reported by parents has increased significantly since the beginning of Covid-19 pandemic (Gassman-Pines et al., 2020). 
The same daily survey data show that psychological suffering has increased in response to the current pandemic in a matter of days (Gassman-Pines et al., 2020).

With the closure of the schools and the onset of the emergency due to the pandemic, many parents began to work from home. This has significantly blurred the temporal and spatial boundaries between paid work and caring for others (Craig \& Churchill, 2020). They had to deal with a new balance between working fulltime at home and home schooling. Those who continue to work outside the home are likely to work in environments that place them at a high level of personal risk, such as hospitals, clinics, grocery stores, and pharmacies.

The balancing of work and family was assisted by government policies, which applied, however, only to employed parents, who are not medical staff. Some of the parents had the right to apply for part-time work, flexible working hours and options for working from home. However, many parents do not have access to "family-friendly" workplace measures and even when they are officially available, there may be unwritten sanctions against access to them (Craig \& Churchill, 2020).

In many cases, families have suffered the negative effects of unemployment and the collapse of economic markets. Research results have also indicated that lower-income families are more significantly affected in terms of well-being during the pandemic, making them even more vulnerable to illness (Coyne et al., 2020).

In addition to high levels of unemployment and financial insecurity, access to traditional social support from extended family and friends has been limited. Many parents often relied on the support of grandparents or other family members for child care or help with household chores. However, due to the requirements of social distancing, this is no longer a possibility, as many grandparents fall into the category of "increased risk" of COVID-19-related diseases, or even death, due to their age or the presence of underlying health conditions.

Many parents also experience loss of access to common sources of socializing and leisure activities, such as churches, fitness centers, bars and restaurants, and in-person interactions with friends. All of these changes and limiting breaks away from home and away from children can put parents at greater risk of parental exhaustion. They have difficulty making time for themselves and finding a balance between their personal, professional and parental responsibilities (Parkes et al., 2015).

Research shows that mental health problems following community-wide disasters or natural crises are widespread, with an impact on individuals and families (Russell et al., 2020). It is known that exposure to a wide range of disasters has a negative impact on mental health and can lead to prolonged periods of increased psychiatric symptoms, including anxiety (Cobham et al., 2016; Gewirtz et al., 2008; McFarlane, 1987; Rodrigo et al., 2012). Factors that can have an impact on mental health include prolonged isolation, distrust, fear of infection, anger, stress, frustration, boredom, inadequate supplies and information, financial loss, and stigma (Costa et al., 2009).

Experts warn that the COVID-19 pandemic can lead to traumatic stress and can exacerbate existing mental health difficulties and lead to the development of new disorders for an extended period of time (Masten \& Osofsky, 2010).

A large survey conducted in China showed that $35 \%$ of the population suffered psychological distress during the COVID-19 outbreak. The response to stress caused by such public health events is generally manifested as anxiety (Wu et al., 2020).

\section{Research methodology}

\subsection{Participants and procedure}

Our sample was formed of 128 participants, parents of primary school pupils, from 15 counties and 32 cities in Romania. Participants $(\mathrm{N}=128)$ completed a questionnaire about demographic characteristics and data about their socio-economic living conditions and how they related to prevention measures (quarantine, school closures, work from home) during the Covid19 pandemic. The sample was selected on-line through a form that was distributed on social networks.

From the sample, $91.40 \%$ were women (mothers) and 8.59 were men (fathers). $0.78 \%$ are between 18 and 25 years old, $39.84 \%$ are between 26 and 35 years old, 52.34\% are between 36 and 45 years old and $7.03 \%$ are between 46 and 55 years old. Regarding marital status, among the participants, $91.40 \%$ are married, $0.78 \%$ live in cohabitation, $1.56 \%$ are unmarried and $6.25 \%$ are divorced. 
Regarding the graduated studies, $2.34 \%$ of the participants completed only grades V-VIII, 9.37\% completed the vocational school, $13.28 \%$ graduated only high school, $72.65 \%$ have a bachelor's or master's degree and $2.34 \%$ completed their doctoral studies.

Regarding the socio-economic situation, $14.84 \%$ of the participants have no income. Of these, $10.52 \%$ come from families in which neither the partner has any income, $15.26 \%$ are single and $15.26 \%$ have a partner who has an income below the average salary in the economy. The others have a partner who has at least an income equal to the average salary in the economy.

$11.71 \%$ of participants have an income below the average salary in the economy. Of these, $13.33 \%$ are from families where the partner has no income, $13.33 \%$ are single and $20 \%$ are from families where the partner has an income below the minimum wage in the economy. Therefore, $73.43 \%$ of the participants have incomes at least equal to the average salary per economy and $26.56 \%$ have an income below the average salary per economy or have no income.

$24.21 \%$ have only one child in care, $45.31 \%$ have 2 children, $21.85 \%$ have 3 children and $8.59 \%$ have more than 3 children.

Figure 1. Percentage of parents participating in the study depending on the number of hours they spend with their children in school activities at home

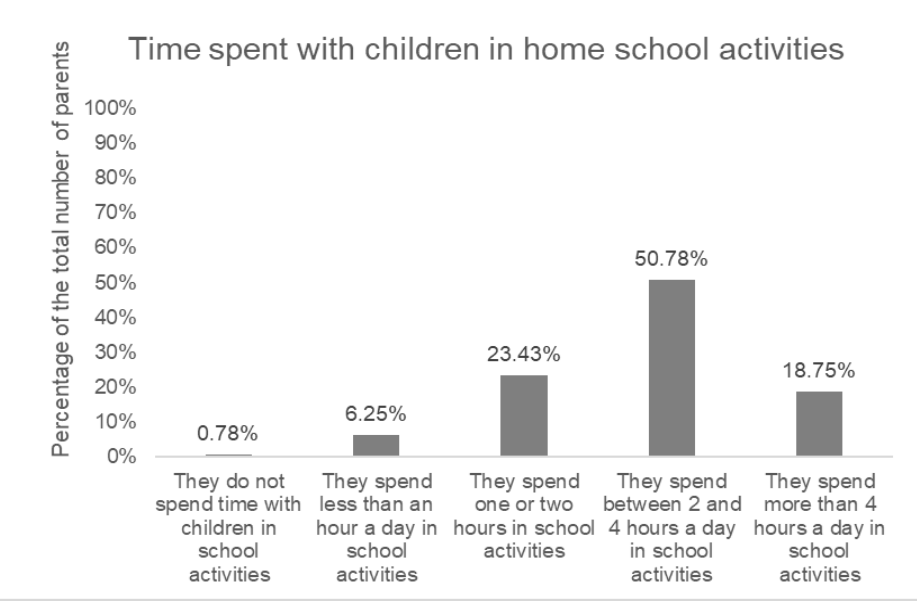

As can be seen in Figure 1, 0,78\% of the parents, participants in our study, do not spend time with their primary school children in home school activities, $6,25 \%$ of parents spend less than an hour a day in school activities with their children, $23,43 \%$ spend one or two hours in school activities, more than a half of the parents spend between 2 and 4 hours a day in school activities and $18,75 \%$ spend more than 4 hours a day in home school activities with their children. During the study, all children did all school activities at home, due to the closure of schools. $77.5 \%$ of parents manage very well to help their children in school activities. It is them easy to explain to them and consider that they understand contents.

$10.15 \%$ of the parents participating in the study suffer from medical conditions that are considered risk factors for severe forms of illness with Covid-19. $5.46 \%$ of participants suffer from an autoimmune disease, $2.34 \%$ suffer from high blood pressure, $0.78 \%$ suffer from diabetes and $1.56 \%$ suffer from other chronic diseases. $18.75 \%$ of the participants live in the same house with a person suffering from a chronic illness.

Only $2.34 \%$ of parents believe that they are very likely to have been in direct contact with a person infected with Covid-19. The other $97.65 \%$ of parents say they did not come or are very unlikely to come into direct contact with a person infected with Covid-19.

In Figure 2, the percentage of the total number of parents and their work conditions during Covid-19 pandemic were presented. $45.70 \%$ of the parents work from home, $17.18 \%$ of the parents are going to work, $17.18 \%$ of the parents are in furlough or unemployed and $18.70 \%$ of the parents are not working.

Figure 2. The percentage of the total number of parents and their work conditions during Covid-19 pandemic

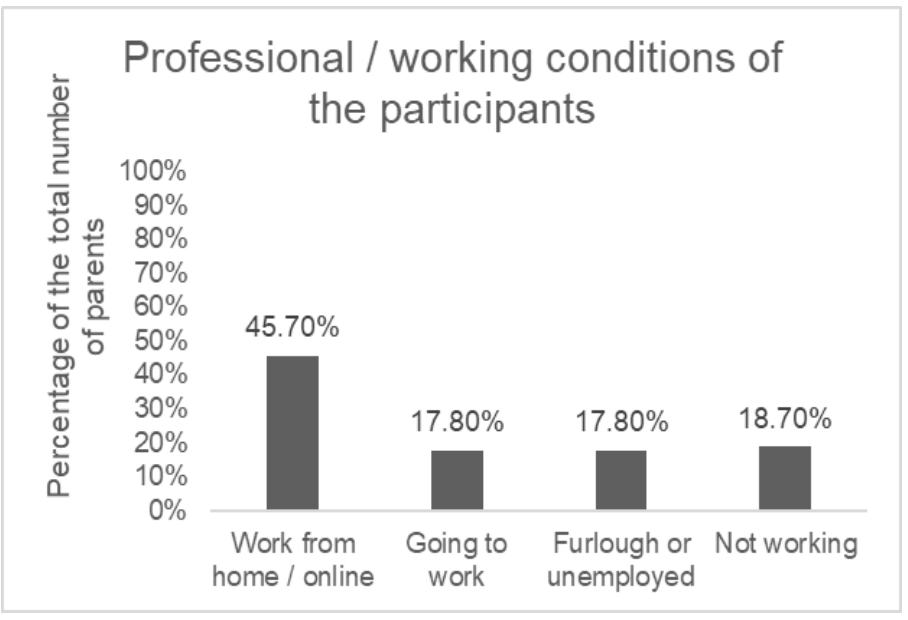

In Figure 3. we presented the extent to which the parents complied or not with the official recommendations regarding the isolation at home and the percentage of the number of parents who were in quarantine imposed by the authorities at the time of the study. 
Figure 3. The percentage of the number of parents and their compliance with isolation or quarantine recommendations

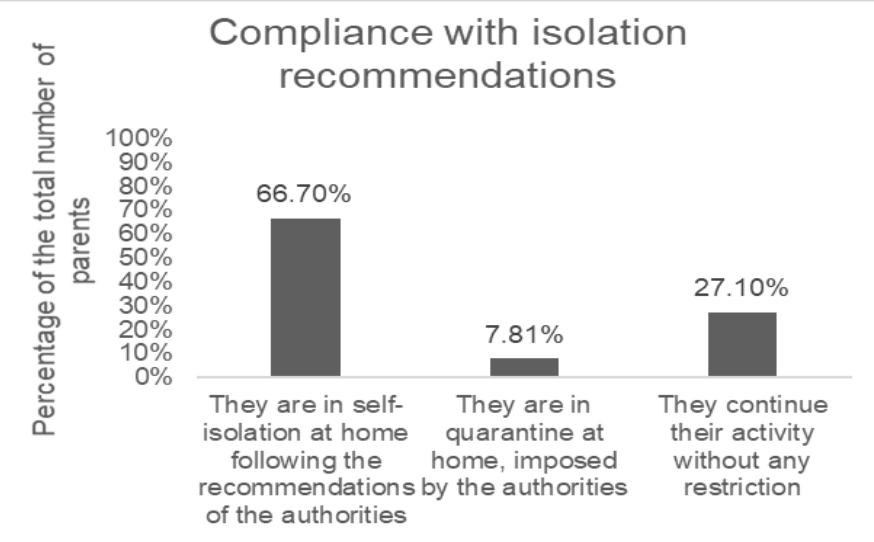

In the following figure, Figure 4, we will present to what extent the parents participating in the study comply with the self-isolation recommendations proposed by the authorities. The situations in that they were allowed to leave the house during the emergency state imposed by the state were: moving between home and work, when the professional activity it is essential and cannot be organized in the form of distance work or travel or for professional reasons that cannot be postponed; specialized medical consultation that cannot be postponed; travel for basic shopping at commercial units in the home area; travel to provide care for the elderly, vulnerable or to accompany children; short trip, close to home, for individual physical activities, excluding any form of collective sports activity; short trip, close to home, related to the needs of pets.

Figure 4 . The percentage of the number of parents and their compliance with isolation or quarantine recommendations, related to the time spent in isolation

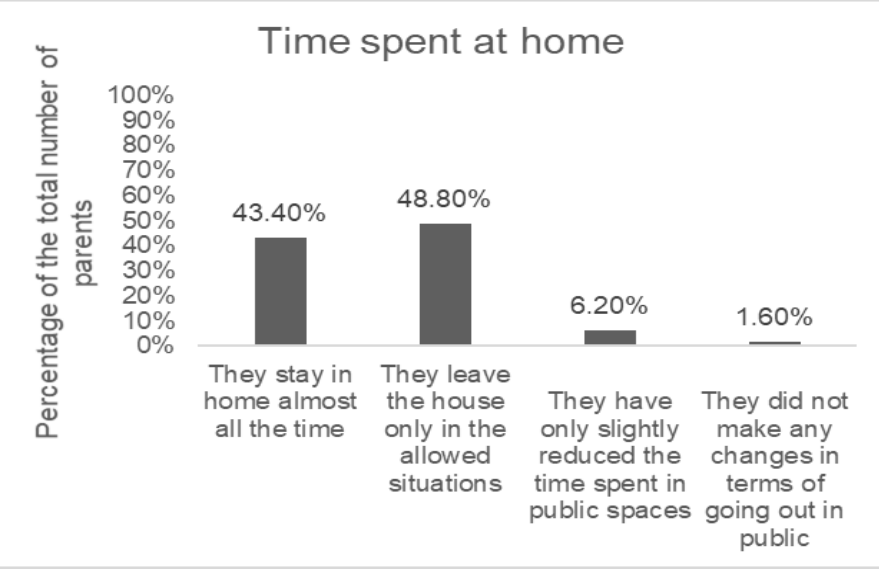

$43.40 \%$ of the parents stay home almost all the time, $48.80 \%$ of them are only leaving the home in the allowed situations described before, $6.20 \%$ have only slightly reduced the time spent in public spaces and $1.60 \%$ of them didn't make any changes. They continue the way of living they had before of the pandemic. $23.3 \%$ of parents leave home every day, $25.6 \%$ leave home 2 or 3 times a week, $30.2 \%$ of parents leave once a week and $20.9 \%$ leave the house only once in a few weeks.

We asked parents how often they seek information through the media about the local, national or international situation regarding the evolution of the Covid-19 pandemic. $74.6 \%$ of them are looking for information about the Covid-19 pandemic a few hours a day. $38 \%$ follow the news about the pandemic only once a day, $13.2 \%$ look for information every few days and $3.1 \%$ do not look for information at all.

We also investigated the perceived social support that parents benefit from. $83.7 \%$ of parents said that they can count on the help of their family members during the COVID-19 pandemic, $31 \%$ of them benefit from the help of friends in need, $17.8 \%$ benefit from the help of neighbors, $14 \%$ from that of co-workers. $10.1 \%$ of participants do not have support from family, friends, neighbors or co-workers.

\subsection{Instruments}

For measuring the anxiety and anger of the participants, we used the N1: Anxiety subscale and the N2: Anger subscale from The Neuroticism Factor (N) in The 30 NEO-PI-R Facet Scales, which are part of the IPIP project. IPIP is a project developed in 1996 by Lewis Goldberg. It was designed as one of international scientific collaboration, allowing access to personality assessment tools and facilitating the ongoing development of assessment scales with the international scientific community. The Romanian adaptation of the International Set of Personality Items: IPIP-Ro was made by Dragoș Iliescu, Marian Popa and Roxana Dimache, in a pilot study, in 2019 (Iliescu et al., 2019).

The NEO PI-R IPIP test is a questionnaire, included in IPIP project, based on the Big Five personality model, measuring the same features as the commercial NEO PI-R. This test allows the comprehensive testing of the human personality. It has five main scales, with 30 component subscales of the profile, providing sufficient information to evaluate the defining characteristics of the profile of each applicant.

Although the researches regarding the NEO PI-R IPIP variant in Romanian are at the beginning, the test results showed that he accurately measures what he intends to measure, having psychometric 
characteristics comparable to the commercial NEO PI$\mathrm{R}$ test.

The five main personality traits measured by this test are: Neuroticism, Extraversion, Openness to Experiences, Pleasantness and Conscientiousness. The Neuroticism Factor $(\mathrm{N})$ comprises 6 scales: Anxiety (N1), Anger-Hostility (N2), Depression (N3), Shyness (N4), Impulsivity (N5) and Vulnerability (N6).

For measuring the energy level we used the Jackson Personality Inventory [JPI-R], part of IPIP project, the Energy Level [Enl] Scale. The Jackson Personality Inventory-Revised provides an assessment of personality and evaluates a variety of social and cognitive factors, which affect an individual's functioning. It was developed by Douglas N. Jackson (Goldberg et. al., 2006) and the pilot study in Romania was done by Dragos Iliescu (Iliescu et al., 2019).

For measuring distrust, we used MPQ Alienation [AL] component of Tellegen's Multidimensional Personality Questionnaire [MPQ], which is also part of the IPIP project. The MPQ is a set of unidimensional self-report scales, each measuring a distinctive trait construct, which together would provide for a comprehensive assessment of normal personality. The current full-length version of the inventory (Tellegen, 2003) comprises 276 items. It contains 11 primary trait scales that operate as indicators of: Positive Emotionality (PEM), Negative Emotionality (NEM), and Constraint (CON). Alienation / distrust is as components of NEM.

We measured also parent's self-efficacy using the General Self-Efficacy Scale (GSE). (Schwarzer, 1995). The General Self-Efficacy Scale is a 10-item psychometric scale that was developed by Matthias Jerusalem and Ralf Schwarzer in 1981. It measures the optimistic self-beliefs to cope with a variety of difficult demands in life.

In the end, we used the Basic Psychological Need Satisfaction and Frustration Scale - General Measure (Chen et al., 2015) to measure the need satisfaction and the need frustration of the parents related to Covid-19 pandemic. The scale was translated by Cătălin Mosoia. This scale has 24 items assessing both need satisfaction and frustration in general in one's life including the three needs for competence, autonomy, and relatedness.

\section{Results}

The sample size of this study $(\mathrm{N}=128)$ is representative for the population studied, for an effect size of $|\rho|=0.3$ and $\alpha$ err prob. $=0.05$.

We examined the correlations between the following variables: anxiety, energy level, anger, distrust, self-efficacy, satisfaction or frustration with relatedness needs, satisfaction or frustration with competence needs and satisfaction or frustration with autonomy needs. We tested the following hypothesis:

H1: There is a significant relationship between the anxiety level and energy level in parents of children in primary school, during Covid-19 pandemic.

For testing the hypothesis we used the Pearson correlation, being fulfilled all the specific assumptions. The result $r=-0.15, p=.08$ did not show that there is a significant relationship between anxiety and the energy level in parents with children in the primary school, during the Covid 19 pandemic.

\section{H2: There is a significant relationship between the} anxiety level and the level of anger in parents of children in primary school, during Covid-19 pandemic.

For testing the hypothesis we used the Pearson correlation, being fulfilled all the specific assumptions. The results $r=0.48, p<.001$ showed that there is a significant relationship between anxiety and anger levels in parents of children in primary school, during Covid-19 pandemic. Moreover, the tested relationship shows a significant positive relationship between the 2 variables, therefore, as the level of anxiety increases, so does the level of anger in parents of children in primary school, during Covid-19 pandemic. Between the 2 variables, there is a $23 \%$ overlap.

H3: There is a significant relationship between the anxiety level and the level of satisfaction in relatedness needs in parents of children in primary school, during Covid-19 pandemic.

For testing the hypothesis we used the Pearson correlation, being fulfilled all the specific assumptions. The results $r=0.26, p=.002$ showed that there is a significant relationship between anxiety and the level of satisfaction in relatedness needs in parents of children in primary school, during Covid-19 pandemic. Moreover, the tested relationship shows a significant positive relationship between the 2 variables, therefore, as the level of anxiety increases, 
so does the level of satisfaction with relatedness needs of parents. Between the 2 variables there is an overlap of $6.76 \%$.

H4: There is a significant relationship between the anxiety level and the level of distrust in parents of children in primary school, during Covid-19 pandemic.

We used the Spearman correlation to test the hypothesis, because not all the specific assumptions for testing the Pearson correlation were met. The result showed that there is a significant relationship between anxiety and the level of distrust in parents: $\rho=0.22$, $p$ $=.012$. Moreover, the tested relationship shows a significant positive relationship between the 2 variables, therefore, as the level of anxiety increases, so does the level of distrust.

H5: There is a significant relationship between the level of anxiety and the level of self-efficacy in parents of children in primary school, during Covid-19 pandemic.

We used the Spearman correlation to test the hypothesis, because not all the specific assumptions for testing the Pearson correlation were met. The result showed that there is a significant relationship between anxiety and the level of self-efficacy in parents during the Covid-19 pandemic: $\rho=-0.29, p=.001$. Moreover, the tested relationship shows a significantly negative relationship between the 2 variables, therefore, as the level of anxiety increases, the level of self-efficacy decreases.

H6: There is a significant relationship between the level of anxiety and the level of satisfaction related to the needs of autonomy in parents of children in primary school, during Covid-19 pandemic.

We used the Spearman correlation to test the hypothesis, because not all the specific assumptions for testing the Pearson correlation were met. The result showed that there is a significant relationship between anxiety and the level of satisfaction related to autonomy needs in parents during the Covid-19 pandemic: $\rho=0.22, p=.011$. Moreover, the tested relationship shows a significant positive relationship between the 2 variables, therefore, as the level of anxiety increases, so does the level of satisfaction related to the needs of autonomy in parents during the Covid-19 pandemic.

H7: There is a significant relationship between the level of anxiety and the level of satisfaction related to the competence needs in parents of children in primary school, during Covid-19 pandemic.

We used the Spearman correlation to test the hypothesis, because not all the specific assumptions for testing the Pearson correlation were met. The result showed that there is a significant relationship between anxiety and the level of satisfaction of competence needs: $\rho=0.23, p=.009$. Moreover, the tested relationship shows a significant positive relationship between the 2 variables, therefore, as the level of anxiety increases, so does the level of satisfaction of competence needs.

H8: There is a significant relationship between the level of anxiety and the level of frustration in relatedness needs in parents of children in primary school, during Covid-19 pandemic.

We used the Spearman correlation to test the hypothesis, because not all the specific assumptions for testing the Pearson correlation were met. The result did not show that there is a significant relationship between anxiety and the level of frustration in relatedness needs of parents during the Covid-19 pandemic: $\rho=-0.14, \mathrm{p}=.112$.

H9: There is a significant relationship between the level of anxiety and the level of frustration related to the need for autonomy in parents with children in primary school, during the Covid pandemic 19.

We used the Spearman correlation to test the hypothesis, because not all the specific assumptions for testing the Pearson correlation were met. The result showed that there is a significant relationship between anxiety and the level of frustration related to the needs for autonomy during the Covid-19 pandemic: $\rho=$ $0.21, p=.016$. Moreover, the tested relationship shows a significantly negative relationship between the 2 variables, therefore, as the level of anxiety increases, the level of frustration related to the needs for autonomy decreases during the Covid-19 pandemic.

H10: There is a significant relationship between the level of anxiety and the level of frustration related to the competence needs in parents of children in primary school, during Covid-19 pandemic..

We used the Spearman correlation to test the hypothesis, because not all the specific assumptions for testing the Pearson correlation were met.The result showed that there is a significant relationship between anxiety and the level of frustration related to the competence needs in parents during the Covid-19 
pandemic: $\rho=-0.29, \mathrm{p}=.001$. Moreover, the tested relationship shows a significantly negative relationship between the 2 variables, therefore, as the level of anxiety increases, the level of frustration related to the competence needs decreases in parents during the Covid-19 pandemic.

The results are presented in Table 1 and Table 2, below:
Table 1. Results of correlation analysis between variables

\begin{tabular}{lcccc}
\hline \multicolumn{1}{c}{ Variables } & Anxiety & Energy & Anger & $\begin{array}{c}\text { Satisfaction } \\
\text { relatedness } \\
\text { needs }\end{array}$ \\
\hline Anxiety & 1 & -.15 & .48 & .26 \\
Energy & -.15 & 1 & -.30 & -.07 \\
Anger & .48 & -.30 & 1 & .37 \\
$\begin{array}{l}\text { Satisfaction } \\
\text { relatedness needs }\end{array}$ & .26 & -.07 & .37 & 1 \\
\end{tabular}

Table 2. Results of nonparametric correlation analysis between variables

\begin{tabular}{|c|c|c|c|c|c|c|c|c|}
\hline Variables & Anxiety & Distrust & $\begin{array}{c}\text { Self- } \\
\text { efficacy }\end{array}$ & $\begin{array}{c}\text { Satisfaction } \\
\text { autonomy } \\
\text { needs }\end{array}$ & $\begin{array}{c}\text { Satisfaction } \\
\text { competence } \\
\text { needs }\end{array}$ & $\begin{array}{c}\text { Frustration } \\
\text { relatedness } \\
\text { needs }\end{array}$ & $\begin{array}{c}\text { Frustration } \\
\text { autonomy } \\
\text { needs }\end{array}$ & $\begin{array}{c}\text { Frustration } \\
\text { competence } \\
\text { needs }\end{array}$ \\
\hline Anxiety & 1 & .22 & -.28 & .22 & .23 & -.14 & -.21 & -.29 \\
\hline Distrust & .22 & 1 & -.28 & .28 & .37 & -.35 & -.21 & -.24 \\
\hline Self-efficacy & -.28 & -.28 & 1 & -.19 & -.31 & .36 & .48 & .63 \\
\hline $\begin{array}{l}\text { Satisfaction } \\
\text { autonomy needs }\end{array}$ & .22 & .28 & -.19 & 1 & .62 & -.25 & -.22 & -.27 \\
\hline $\begin{array}{l}\text { Satisfaction } \\
\text { competence } \\
\text { needs }\end{array}$ & .23 & .37 & -.31 & .62 & 1 & -.34 & -.13 & -.20 \\
\hline $\begin{array}{l}\text { Frustration } \\
\text { relatedness } \\
\text { needs }\end{array}$ & -.14 & -.35 & .36 & -.25 & -.34 & 1 & .54 & .61 \\
\hline $\begin{array}{l}\text { Frustration } \\
\text { autonomy needs }\end{array}$ & -.21 & -.21 & .48 & -.22 & -.13 & .54 & 1 & .64 \\
\hline $\begin{array}{l}\text { Frustration } \\
\text { competence } \\
\text { needs }\end{array}$ & -.29 & -.24 & .63 & -.27 & -.20 & .61 & .64 & 1 \\
\hline
\end{tabular}

\section{Discussions}

Significantly negative correlations were found between anxiety and self-efficacy and between anxiety and frustration regarding competence needs. If the first correlation can be anticipated, the second was surprising. These results contradicted the results of several studies. For example, Nogas et al. (1974) found a negative correlation between death anxiety and the sense of competence. Thorough research would be needed to better understand this relation.

Significantly negative correlations were also observed between distrust and self-efficacy, distrust and frustration in relatedness needs, distrust and frustration related to competence needs and a significantly positive correlation between distrust and satisfaction with autonomy needs. A careful analysis of these relationships and the extent to which the pandemic situation has influenced these relationships is needed.

In terms of self-efficacy, significantly positive correlations were found between self-efficacy and frustration in relatedness needs, self-efficacy and frustration with autonomy needs, and self-efficacy and frustration with competence needs. These results were also surprising. One explanation could be the 
heterogeneity of the sample or the pandemic situation that could influence the results.

\section{Conclusions}

At this time, we all live unique life experiences, when a global pandemic has led to significant changes for almost every aspect of our daily lives.

The results of this study provide information about the experiences of parents in the first weeks of the COVID-19 pandemic, however, several limitations should be mentioned. Given the lack of a baseline, a pre-pandemic assessment of this sample, our results provide only a description of the early experiences of Romanian parents at the beginning of the COVID-19 pandemic (April-June). Stronger inferences require longitudinal data. Among the limitations of this study we mention, also, the size and the heterogeneity of the sample.

The psychological effects of the COVID-19 outbreak are still being studied. How this crisis, social distancing and restrictive measures affect the mental health of children and parents is a major challenge in the field (Holmes et al., 2020; C. Wang et al., 2020). Studying these effects and the results of these studies can help better inform researchers, social actors and policy makers to develop effective guidelines for future outbreaks, in order to promote the maintenance of mental health and encourage the well-being of families (Jiménez et al., 2019). This requires in particular prevention programs specifically geared to the needs of the family in the context of a health crisis. Specific tools have already been developed to increase family well-being during the pandemic (Coyne et al., 2020; Szabo et al., 2020) which could help improve family adjustment and parental behaviors (Romero et al., 2020).

\section{Acknowledgments}

This study was conducted with the financial support of the Human Capital Operational Program 2014-2020, through the POCU 123793 project entitled "Researcher, future entrepreneur - The new generation".

Authors note: The authors have equal contributions to this article.

Cristina S. Sălăgean is a $\mathrm{PhD}$. Student at "Education, Reflection, Development" Doctoral School, Babes-Bolyai University, in Cluj-Napoca. She is a private practice psychologist in the specialization of Special Psychopedagogy and has over 10 years of teaching and therapeutic intervention experience with children with Special Educational Needs. Her areas of interest for research are: Autism Spectrum Disorders, Applied Behavior Analysis and Inclusive Education.

Editha Coşarbă is a PhD. Student at "Education, Reflection, Development" Doctoral School, BabesBolyai University, in Cluj-Napoca. For 15 years she has worked as a speech therapist at the Arad County Center for Educational Resources and Assistance.

\section{References}

Bandura, A. (1983). Self-efficacy determinants of anticipated fears and calamities. Journal of Personality and Social Psychology, 45(2), 464-469.

Bradley, R. A. (2007). Parenting in the breach: How parents help children cope with developmentally challenging circumstances. Parenting, 7(2), 99-148.

Chen, B., Vansteenkiste, M., Beyers, W., Liesbet Boone, Deci, E. L., Van Der Kaap-Deeder, J., Duriez, B., Lens, W., Matos, L., Mouratidis, A., Ryan, R. M., Kennon, Sheldon, M., Soenens, B., Stijn, Petegem, V., \& Verstuyf, J. (2015). Basic psychological need satisfaction, need frustration, and need strength across four cultures. Springer, 39(2), 216-236.

Craig, L., \& Churchill, B. (2020). Dual-earner parent couples'work and care during COVID-19. Gender, Work \& Organization, 28 (S1), 66-67.

Cobham, V. E., McDermott, B., Haslam, D., \& Sanders, M. R. (2016). The Role of Parents, Parenting and the Family Environment in Children's Post-Disaster Mental Health. In Current Psychiatry Reports. Vol. 18, Issue 6, pp. 1-9. Current Medicine Group LLC 1.

Conger, R. D., Wallace, L. E., Sun, Y., Simons, R. L., McLoyd, V. C., \& Brody, G. H. (2002). Economic pressure in African American families: a replication and extension of the family stress model. Developmental Psychology, 38(2), 179-193.

Connor, K. M., \& Davidson, J. R. T. (2003). Development of a new Resilience scale: The Connor-Davidson Resilience scale (CD-RISC). Depression and Anxiety, 18(2), 76-82.

Costa, N. M., Weems, C. F., \& Pina, A. A. (2009). Hurricane Katrina and youth anxiety: The role of perceived attachment beliefs and parenting behaviors. Journal of Anxiety Disorders, 23(7), 935-941.

Coyne, L. W., Gould, E. R., Grimaldi, M., Wilson, K. G., Baffuto, G., \& Biglan, A. (2020). First things first: Parent psychological flexibility and self-compassion during COVID-19. Behavior Analysis in Practice, 1.

Deater-Deckard, K. (1998). Parenting stress and child adjustment: Some old hypotheses and new questions. Clinical Psychology: Science and Practice, 5(3), 314332.

Gassman-Pines, A., Ananat, E. O., \& Fitz-Henley, J. (2020). COVID-19 and parent-child psychological well- 
being.

Pediatrics,

$146(4)$

(https://doi.org/10.1542/peds.2020-007294).

Gewirtz, A., Forgatch, M., \& Wieling, E. (2008). Parenting Practices as Potential Mechanisms for Child adjustment Following Mass Trauma. Journal of Marital and Family Therapy, 34(2), 177-192.

Gordillo, R. G. (2020). COVID-19 and Labour Law: Spain. Italian Labour Law E-Journal Special Issue 1, 13(1S).

Holmes, E. A., O’Connor, R. C., Perry, V. H., Tracey, I., Wessely, S., Arseneault, L., Ballard, C., Christensen, H., Cohen Silver, R., Everall, I., Ford, T., John, A., Kabir, T., King, K., Madan, I., Michie, S., Przybylski, A. K., Shafran, R., Sweeney, A., ... Bullmore, E. (2020). Multidisciplinary research priorities for the COVID-19 pandemic: a call for action for mental health science. In The Lancet Psychiatry. Vol. 7, Issue 6, pp. 547-560. Elsevier Ltd.

Iliescu, D., Popa, M., \& Dimache, R. (2019). Adaptarea românească a Setului Internaţional de Itemi de Personalitate: IPIP-Ro. Psihologia Resurselor Umane, 13(1), 83-112.

Jiao, W. Y., Wang, L. N., Liu, J., Fang, S. F., Jiao, F. Y., Pettoello-Mantovani, M., \& Somekh, E. (2020). Behavioral and emotional disorders in children during the COVID-19 epidemic. The journal of Pediatrics, 221, 264.

Jiménez, L., Antolín-Suárez, L., Lorence, B., \& Hidalgo, V. (2019). Family education and support for families at psychosocial risk in Europe: Evidence from a survey of international experts. Health and Social Care in the Community, 27(2), 449-458.

Kaya, A., \& Fang, H.Y. (1997). Identification of Contaminated Soils by Dielectric Constant and Electrical Conductivity. Journal of Environmental Engineering, 123(2), 169-177.

Lindström, K., Lindblad, F., \& Hjern, A. (2011). Preterm birth and attention-deficit/hyperactivity disorder in schoolchildren. Pediatrics, 127(5), 858-865.

Masten, A. S., \& Osofsky, J. D. (2010). Disasters and their impact on child development: Introduction to the special section. Child Development, 81(4), 1029-1039.

Mazza, M., Marano, G., Lai, C., Janiri, L., \& Sani, G. (2020). Danger in danger: Interpersonal violence during COVID-19 quarantine. Psychiatry Research, 289, 113046.

McFarlane, A. C. (1987). Family functioning and overprotection following a natural disaster: The longitudinal effects of post-traumatic morbidity. Australian and New Zealand Journal of Psychiatry, 21(2), 210-218.

Mikkonen, J., \& Raphael, D. (2010). Social determinants of health: The Canadian facts. Available at: https://ses.sp.bvs.br/local/File/Social Determinants of Health_The Canadian Facts.pdf (Accessed at 20.10.2020).

Neece, C. L., Green, S. A., \& Baker, B. L. (2012). Parenting stress and child behavior problems: A transactional relationship across time. American Journal on Intellectual and Developmental Disabilities, 117(1), 4866.

Nogas, C., Schweitzer, K., \& Grumet, J. (1974). An investigation of death anxiety, sense of competence, and need for achievement. OMEGA-Journal of Death and Dying, 5(3), 245-255.

Norris, F. H., Friedman, M. J., Watson, P. J., Byrne, C. M., Diaz, E., \& Kaniasty, K. (2002). 60,000 Disaster victims speak: Part I. An empirical review of the empirical literature, 1981-2001. Psychiatry, 65(3), 207-239.

Parkes, D. C., Procaccia, A. D., \& Shah, N. (2015). Beyond dominant resource fairness: Extensions, limitations, and indivisibilities. ACM Transactions on Economics and Computation (TEAC), 3(1), 1-22.

Patrick, S. W., Henkhaus, L. E., Zickafoose, J. S., Lovell, K., Halvorson, A., Loch, S., Letterie, M., \& Davis, M. M. (2020). Well-being of Parents and Children During the COVID-19 Pandemic: A National Survey. Pediatrics, 146(4), e2020016824.

Prime, H., Wade, M., \& Browne, D. T. (2020). Risk and resilience in family well-being during the COVID-19 pandemic. American Psychologist, 75(5), 631-643.

Qiu, J., Shen, B., Zhao, M., Wang, Z., Xie, B., \& Xu, Y. (2020). A nationwide survey of psychological distress among Chinese people in the COVID-19 epidemic: Implications and policy recommendations. In General Psychiatry. Vol. 33, Issue 2, p. 100213. BMJ Publishing Group.

Rodrigo, M. J., Almeida, A., Spiel, C., \& Koops, W. (2012). Introduction: Evidence-based parent education programmes to promote positive parenting. In European Journal of Developmental Psychology. Vol. 9, Issue 1, pp. 2-10. Psychology Press.

Romero, E., López-Romero, L., Domínguez-Álvarez, B., Villar, P., \& Gómez-Fraguela, J. A. (2020). Testing the Effects of COVID-19 Confinement in Spanish Children: The Role of Parents' Distress, Emotional Problems and Specific Parenting. International Journal of Environmental Research and Public Health, 17(19), 6975.

Roskam, I., Brianda, M. E., \& Mikolajczak, M. (2018). A Step Forward in the Conceptualization and Measurement of Parental Burnout: The Parental Burnout Assessment (PBA). Frontiers in Psychology, 9(JUN), 758.

Russell, B. S., Hutchison, M., Tambling, R., Tomkunas, A. J., \& Horton, A. L. (2020). Initial Challenges of Caregiving During COVID-19: Caregiver Burden, Mental Health, and the Parent-Child Relationship. Child Psychiatry and Human Development, 51(5), 671682.

Sameroff, A. (2009). The transactional model. In The transactional model of development: How children and contexts shape each other. (pp. 3-21). American 
Psychological Association.

Sari, P., Pajarianto, H., Kadir, A., Galugu, N., \& Februanti, S. (2020). Study from Home in the Middle of the COVID19 Pandemic: Analysis of Religiosity, Teacher, and Parents Support Against Academic Stress. 12(2s), 17911807.

Schwarzer, R., \& Jerusalem, M. (1995). Generalized selfefficacy scale. In J. Weinman, S. Wright, \& M. Johnston (Eds.), Measures in health psychology: A user's portfolio. Causal and control beliefs. (pp. 35-37). Windsor, UK: NFER-NELSON.

Séjourné, N., Sanchez-Rodriguez, R., Leboullenger, A., \& Callahan, S. (2018). Maternal burn-out: an exploratory study. Journal of Reproductive and Infant Psychology, 36(3), 276-288.

Shea, S. E., \& Coyne, L. W. (2011). Maternal dysphoric mood, stress, and parenting practices in mothers of head start preschoolers: The role of experiential avoidance. Child and Family Behavior Therapy, 33(3), 231-247.

Sohrabi, C., Alsafi, Z., O’Neill, N., Khan, M., Kerwan, A., Al-Jabir, A., Iosifidis, C., \& Agha, R. (2020). World Health Organization declares global emergency: A review of the 2019 novel coronavirus (COVID-19). In International Journal of Surgery. Vol. 76, pp. 71-76. Elsevier Ltd.

Sorkkila, M., \& Aunola, K. (2020). Risk Factors for Parental Burnout among Finnish Parents: The Role of Socially Prescribed Perfectionism. Journal of Child and Family Studies, 29(3), 648-659.

Spinelli, M., Lionetti, F., Pastore, M., \& Fasolo, M. (2020). Parents' Stress and Children's Psychological Problems in Families Facing the COVID-19 Outbreak in Italy. Frontiers in Psychology, 11, 1713.

Szabo, T. G., Richling, S., Embry, D. D., Biglan, A., \& Wilson, K. G. (2020). From Helpless to Hero: Promoting Values-Based Behavior and Positive Family Interaction in the Midst of COVID-19. Behavior Analysis in Practice, 13(3), 568-576.

Tedeschi, R. G., Shakespeare-Finch, J., Taku, K., \& Calhoun, L. G. (2018). Posttraumatic growth: Theory, research, and applications. Routledge.

Tellegen, A. (2003). Multidimensional Personality Questionnaire (MPQ). Unpubl. manuscr., University.

Usher, K., Bhullar, N., Durkin, J., Gyamfi, N., \& Jackson, D. (2020). Family violence and COVID-19: Increased vulnerability and reduced options for support. International journal of mental health nursing, 29 (4), 549-552.

Wang, C., Pan, R., Wan, X., Tan, Y., Xu, L., Ho, C. S., \&
Ho, R. C. (2020). Immediate Psychological Responses and Associated Factors during the Initial Stage of the 2019 Coronavirus Disease (COVID-19) Epidemic among the General Population in China. International Journal of Environmental Research and Public Health, 17(5), 1729.

Wang, D., Hu, B., Hu, C., Zhu, F., Liu, X., Zhang, J., Wang, B., Xiang, H., Cheng, Z., Xiong, Y., Zhao, Y., Li, Y., Wang, X., \& Peng, Z. (2020). Clinical Characteristics of 138 Hospitalized Patients with 2019 Novel Coronavirus-Infected Pneumonia in Wuhan, China. JAMA - Journal of the American Medical Association, 323(11), 1061-1069.

Williford, A. P., Calkins, S. D., \& Keane, S. P. (2007). Predicting change in parenting stress across early childhood: Child and maternal factors. Journal of Abnormal Child Psychology, 35(2), 251-263.

Wu, M., Xu, W., Yao, Y., Zhang, L., Guo, L., Fan, J., \& Chen, J. (2020). Mental health status of students' parents during COVID-19 pandemic and its influence factors. General Psychiatry, 33(4).

Xie, X., Xue, Q., Zhou, Y., Zhu, K., Liu, Q., Zhang, J., \& Song, R. (2020). Mental health status among children in home confinement during the coronavirus disease 2019 outbreak in Hubei Province, China. In JAMA Pediatrics. Vol. 174, Issue 9, pp. 898-900. American Medical Association.

Zhou, P., Yang, X. Lou, Wang, X. G., Hu, B., Zhang, L., Zhang, W., Si, H. R., Zhu, Y., Li, B., Huang, C. L., Chen, H. D., Chen, J., Luo, Y., Guo, H., Jiang, R. Di, Liu, M. Q., Chen, Y., Shen, X. R., Wang, X., ... Shi, Z. L. (2020). A pneumonia outbreak associated with a new coronavirus of probable bat origin. Nature, 579(7798), 270-273.

Digi24, Astăzi este ultima zi de stare de urgenţă în România. Ce se schimbă când intră în vigoare starea de alertă, Available at: https://www.digi24.ro/stiri/actualitate/astazi-esteultima-zi-de-stare-de-urgenta-in-romania-starea-dealerta-intra-insa-in-vigoare-peste-trei-zile-1306802 (accessed at 07.11.2020).

World Health Organization, WHO Director-General's remarks at the media briefing on 2019-nCoV on 11 February 2020, Available at: https://www.who.int/directorgeneral/speeches/detail/who-director-general-sremarks-at-the-media-briefing-on-2019-ncov-on-11february-2020 (accessed at 07.11.2020). 


\title{
Educația digitală
}

\section{by Ciprian Ceobanu, Constantin Cucoș, Olimpius Istrate, Ion-Ovidiu Pânişoară}

\author{
Polirom Publishing House, 2020, pp. 374
}

(ISBN: 978-973-46-8200-3)

\section{Reviewed by Gina Florentina Tudorache ${ }^{a, b^{*}}$}

\author{
a ,Gheorghe Lazăr” School, Barcanesti, Prahova \\ ${ }^{b}$ Petrolem - Gas University of Ploiesti, Teacher Training Department, 39 Bucharest Avenue, Ploiesti 100680, Romania \\ *Corresponding author: gina.tudorache16@yahoo.com
}

\section{Data about the authors}

Ciprian Ceobanu is a Professor, Ph. D., at the Faculty of Psychology and Educational Sciences and the Head of the Teacher Training Department within "Alexandru Ioan Cuza" University of Iași. He has published various articles and specialized studies, the fields of competence being: educational psychology, computer-based learning, e-learning and m-learning.

Constantin Cucoş is a Professor, Ph. D., at the Faculty of Psychology and Educational Sciences within "Alexandru Ioan Cuza" University of Iași. He is the author of over 200 studies in collective volumes or specialized journals, his fields of competence being: trainers' training, philosophy of education, pedagogy of culture, religious education, intercultural pedagogy.

Olimpius Istrate is an Associate Professor in the Teacher Training Department, Faculty of Psychology and Educational Sciences, University of Bucharest, where he teaches Computer Based Learning. He holds a $\mathrm{PhD}$ in education sciences and during his professional career he has held positions such as: researcher at the Institute of Education Sciences (Bucharest), education manager for Southeast Europe at Intel (Bucharest), e-learning coordinator for the CRED project at the Institute of Sciences of Education.

Ion-Ovidiu Pânișoară is a Professor, $\mathrm{Ph}$. D. at the Faculty of Psychology and Educational Sciences, University of Bucharest, being the Head of the Teacher Training Department and Ph.D. supervisor in the field of educational sciences. He is involved in the elaboration of educational policies in the field of teacher training, publishing numerous studies and scientific papers in this field.

Along with the above mentioned coordinators, the volume "Digital Education" was supported by the extensive experience in scientific research of an impressive number of lecturers, associate professors and professors who carry out teaching at various universities in the country, such as: Beatrice Aurelia Abalașei, Simona Adam, Roxana Apostolache, Marilena Bratu, Ruxandra Chircă, Dana Crăciun, Versavia Curelaru, Silvia Făt, Alois Gherguț, Roxana Ghiațău, Cătălin Glava, Gabriela Grosseck, Carmen Holotescu, Mihai Iacob, Marian Ilie, Olimpius Istrate, Iuliana Lazăr, Andrei Lucian Marian, Cornelia Măiran, Ioan Naecșu, Raluca Mihaela Onose, Georgeta Pânișoara, Nicoleta Laura Popa, Dorina Sălăvăstru, Emil Stan, Adriana-Maria Șandru, DanielMihail Șandru, Simona Velea, Florin Emil Verza.

The present context of the educational process in the digitalization age

The social crisis triggered by the COVID-19 pandemic has brought intense changes in the educational system, moving, for greater safety, the entire teaching activity in the online environment. In the face of these unprecedented challenges, the school had to quickly reinvent itself, considering the digitalization of education a way to facilitate the transition and adaptation to this future. Thus, elearning with all its adjacent extensions - m-learning, u-learning - became the pillar of the entire instructiveeducational process. 
Beyond the advantages that new technologies offer by facilitating the provision of contents, understanding and mastering them based on the presentation of augmented virtual realities, by exposing a variety of educational resources to which any educational actor can have free access, by the support it offers in the management of the educational process, they have repercussions in the socio-educational sphere, of the individual learning, but also of the implementation of the educational action.

Thus, the feasible adoption and incorporation of information, communication and digital technologies in the Romanian education system during the SARSCoV-2 pandemic generates accentuated challenges, such as:

- the adoption of new technologies as a foundation for the development of the entire educational process;

- the design and implementation of a computerized curriculum;

- the training of teachers in order to effectively use the new techno-social framework in educational processes;

- the removal of the digital segregation among the educational stakeholders (students, teachers, parents), in terms of lack of computer resources and deficiencies in digital skills;

- the removal of the school reluctance in the face of all these phenomena that question its traditional role.

Designed in a theoretical-reflective, but also practical-applicative way, this book aims to offer solutions for the variety of changes and challenges to which the education system must respond, presenting the relevant trends in the development of technologically adjusted educational environments.

Therefore, against the background of a rich experience in the field of educational sciences research, the authors consider the following issues:

- how and to what extent the traditional education will find itself in the online environment;

- how the digital gap among all educational stakeholders will be eliminated;

- what the impact of the digitalization of education on the learning process is and how this phenomenon affects the role of the teacher;

- what the optimal technological level used in the educational process is so that undesirable subsidiary consequences can be avoided;
- what the responsibilities of the various factors responsible for supporting the education system in the optimal implementation of digital education are and how they should work together to ensure the feasibility of this process.

It is clear that in this increasingly emphasized position of new technologies, the learning process is resized in terms of contents, human learning mechanisms and the role that the teacher has between cognitive mediation and knowledge. The virtual learning environment offers students unlimited access to information, which makes learning through technological processes to acquire a different configuration, based on curiosity, interaction, collaboration, discovery, experimentation etc. These multiple computerized interactions between students and the contents to be learned are mediated by the teacher whose role shifts its focus from "information detonator" to guiding and motivating students, to maximizing their abilities.

From our point of view, it is imperative that the teacher understands this change in terms of his/her purpose, that of "main vector of educational dynamics" (Pânișoară, 2017, p. 13), shows courage, determination and openness to change so as to understand the changing profile of generations of students, caused by social dynamics, in order to guide them in the efficient use of technology and to develop skills to adapt to the unpredictable.

\section{The structure of the book}

Being structured in five parts, the book presents an almost exhaustive framework of the educational process in front of the digitalization of education, starting from "Socio-cultural perspectives on the use of technology in education". Thus, the educational reconfigurations in the era of digital technology, the reference of digital competences, the educational determinations of social networks, ethics and technology in the educational context, the risks and safety of using information technologies in educational contexts, protection and security of personal data in digital education are all considered.

At the same time, the paper presents guiding aspects to the education stakeholders responsible for the good implementation of digital education, representing "Forms and hypostases of technologybased learning". Therefore, it describes the educational process in the perspective of digitalization, emphasizes the importance of using digital tools and resources in improving the education 
process, presents explanatory models of learning using information and communication technologies, explains the changing profile of individual learning in the digital technology era, presents learning principles self-regulated in the virtual environment, the dimensions of computer-based learning, as well as the benefits of m-learning (mobile learning) and $\mathrm{u}$ learning (ubiquitous learning), as extensions of elearning.

Moreover, the book draws attention to "Technology in shaping pedagogical innovation", presenting essential categories of online learning platforms, socio-professional networks for collaborative learning with new technologies and also emphasizes the importance of open education, with its many facets (access to educational resources quality, massive open online courses, open educational practices), all meant to progress in the new digital society.

With the same accuracy, the authors continue to present "The specificity of the teaching process in the technological age", reflecting on digital education as a feasible technique for functional and innovative teaching, describing pedagogical mediation in the digital age, presenting the characteristics and quality criteria of e-learning media and explaining the role of digital textbooks. They also clearly present the process for assessing school and academic performance in digital educational environments, as well as guidelines for choosing effective teacher training programs for education today.

At the same time, the authors consider "Using technology for educational support services", studying digital technology in career counseling, addressing new technologies in special education and school inclusion of children with special needs, presenting the advantages and limitations of using modern technologies in teaching STEM subjects to students with intellectual disabilities, but also the role of technology in the psychomotor skills.

\section{Conclusion}

In the context of inserting technology in the educational process, "Digital Education" indicates the coordinates of the relationship between teachinglearning-assessment, with reflections in the field of online education. Against the background of extensive experience in the field of educational sciences research, the authors seek to provide a quick response to the constraints generated by the recent crisis situation.
In an almost complete representation of the current context in which the educational process is at present, the paper presents reference principles that increase the stimulating dimension of deepening and researching new heuristic solutions.

Reviewed by Gina Florentina Tudorache 